\author{
UNIVERSIDADE DE SÃO PAULO \\ FACULDADE DE FILOSOFIA, LETRAS E CIÊNCIAS HUMANAS \\ DEPARTAMENTO DE GEOGRAFIA \\ PROGRAMA DE PÓS-GRADUAÇÃO EM GEOGRAFIA HUMANA
}

REGNALDO GOUVEIA DOS SANTOS
Área de Influência Real de Empreendimentos Hidroelétricos do ponto de vista da Geografia: o caso dos rios São Francisco e Nilo

Versão corrigida

São Paulo 


\title{
Área de Influência Real de Empreendimentos Hidroelétricos do ponto de vista da Geografia: o caso dos rios São Francisco e Nilo
}

Tese apresentada ao Departamento de Geografia da Faculdade de Filosofia, Letras e Ciências Humanas da Universidade de São Paulo, para obtenção do título de Doutor em Geografia.

Área de concentração: Geografia Humana Orientador: Prof. Dr. Mário De Biasi

\author{
Versão corrigida
}

De acordo

Professor Dr. Mário De Biasi

São Paulo 


\section{FOLHA DE APROVAÇÃO}

Regnaldo Gouveia dos Santos

Área de Influência Real de Empreendimentos Hidroelétricos do ponto de vista da Geografia: o caso dos rios São Francisco e Nilo

Tese apresentada ao Departamento de Geografia da Faculdade de Filosofia, Letras e Ciências Humanas da Universidade de São Paulo, para obtenção do título de Doutor.

Área de concentração: Geografia Humana

Aprovado em:

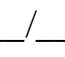

1

Banca Examinadora

$\operatorname{Prof(a).~Dr(a).~}$

Instituição:

Assinatura:

Prof(a). Dr(a).

Instituição:

Assinatura:

$\operatorname{Prof(a).~Dr(a).~}$

Instituição:

Assinatura:

Prof(a). Dr(a).

Instituição:

Assinatura:

Prof(a). Dr(a).

Instituição:

Assinatura: 


\section{DEDICATÓRIA}

A Deus Pai, Filho e Espírito Santo. Abaixo da Santíssima Trindade, a meus pais Nelson

e Maria Genisete, à minha esposa Gênia e ao nosso filho Dêjeces, além de todos os meus irmãos.

De maneira especial, dedico também ao Professor Doutor Mário De Biasi e ao Professor Doutor José Bueno Conti por acreditarem no desenvolvimento deste estudo.

Em memória ao Professor Dr. Aziz Nacib Ab’Sáber, pela sua contribuição acadêmica que tem sido uma das principais fundamentações da tese defendida na presente pesquisa.

Enfim, à sociedade em geral, sobremaneira, àqueles em defesa da causa ambiental e de um desenvolvimento sustentável. 


\section{AGRADECIMENTOS}

Sobre tudo e todas as coisas, a Deus. Aos meus pais Nelson e Maria Genisete, pela educação e valores que me ensinaram.

De forma especial, ao Professor Dr. Mário De Biasi pela sua presteza, atenção, colaboração e pertinentes orientações.

De modo particular e com uma gratidão sublime, ao Professor Dr. José Bueno Conti, estudioso e apaixonado pelo semiárido brasileiro, pela inestimável contribuição dada durante a elaboração deste trabalho; não só quanto ao conteúdo, como também na orientação metodológica. Assim, reforço meus sinceros agradecimentos a este ilustre Mestre da USP.

À Professora Dra. Neli Aparecida de Mello Théry pelas importantes sugestões dadas no exame de qualificação que desempenharam relevante contribuição norteadora na conclusão do presente feito.

Aos Professores Dr. Marcelo Martinelli, Dra. Maria Laura Silveira, Dr. Hervé Théry, Dr. Anselmo Alfredo, Dra. Rita Cruz e todos os outros Ilmos. Professores do Departamento de Geografia da USP que, fundamentalmente, através de nossos diálogos, contribuíram com a minha carreira acadêmica.

Ao meu amigo José Pereira Albuquerque (mais conhecido como Pereira), professor de Português/Inglês, pela sua dedicação e valiosas observações, ao longo da revisão final deste trabalho.

Enfim, os meus sinceros agradecimentos a todos que, de alguma forma, direta ou indiretamente, contribuíram para a realização das visitas de campo e incentivaram o estudo, proporcionando minha chegada até aqui. 
“Em São Paulo, um dia, em 1992, um político do Grande Norte brasileiro assim falou: 'os que vierem depois de nós que recebam o mundo que nós deixarmos, tal como nós recebemos o mundo que outros nos deixaram [...]'. Uma frase enfática e ignorante como essa contraria tudo o que podemos obter com a melhoria e o aprofundamento técnico-científico e ético das tarefas de previsão de impactos. Evidentemente, muitos e muitos políticos precisam ser (re)educados e (re)orientados para atender corretamente aos cenários de seu país e sua gente, em diferentes profundidades do futuro".

Ab'Sáber 


\section{RESUMO}

Este trabalho levanta discussão de um tema que importa à comunidade acadêmica e à sociedade em geral frente à conjuntura mundial como se encontra a questão ambiental e, consequentemente, a situação social. O presente estudo realizou-se, em estrito senso, na concepção da geografia cultural, analisando a paisagem e interpretando a relação homem natureza no espaço geográfico. Empenhou-se em contextualizar e defender o conceito de Área de Influência Real de Empreendimentos Hidroelétricos do ponto de vista da Geografia (Airehg). Os critérios definidos a partir das características do espaço físico e do impacto socioambiental passaram a consolidar o contexto do tema em epígrafe através de suas descrições e argumentações. Comparando o Rio São Francisco ao Nilo, sobretudo, os seus baixos cursos como o caso examinado, foram reveladas variáveis semelhantes e comuns aos rios, consistentes aos critérios elencados para sustentarem o assunto proposto à pesquisa. Ao confrontar Estudos de Impactos Ambientais - Relatórios de Impactos Ambientais (EIA/Rima(s)) com a Lei de Política Nacional do Meio Ambiente (Lpnma) e a concepção da Geografia a respeito da área de influência de empreendimentos hidroelétricos com potencial acima de 10 MW, denotou-se que há um problema de ajuste na supracitada lei. Observou-se também que ao considerar a Airehg, após regulamentação legal, o EIA/Rima pode, assim, estar a caminho de solucionar o referido problema. Toda a abordagem consolidou-se em defesa da tese e de que o documento elaborado pelos empreendedores hidroelétricos precisa reconhecer e adotar como área de influência a representada no tema em epígrafe e, antes de tudo, passe a ser uma das exigências da Lpnma; o que é crucial para manter o Brasil adiantado nestes termos, no cenário internacional, certo de que em qualquer parte do globo terrestre tal contexto ainda não está sendo aplicado, segundo a consulta da bibliografia constante.

Palavras-chave: Airehg; Geografia; meio ambiente; política ambiental; previsão de impactos. 


\begin{abstract}
This paper brings the discussion of a subject that matters to the academic community and society at large by world conjuncture as seen in the environmental issue, and consequently, the social one. This study was carried out, in strict sense, in the conception of the cultural geography and analyzing the scenery and interpreting the relation between man and nature in geographic space. It endeavored to contextualize and defend the concept of Real Influence Area of Hydroelectric Enterprises from the point of view of Geography (Riaheg). The criteria set from the characteristics of the physical space and of the social and environmental impact began to consolidate the context of the above theme through their descriptions and arguments. Comparing the San Francisco River to the Nile, especially its lower courses such as the case examined, proved to be similar and shared common variables to the rivers, consistent to the criteria listed for sustaining the proposed subject to the research. Confronting Environmental Impact Assignments - Environmental Impact Report (EIA/EIR) with the National Environmental Policy Act (Nepa) and the design of Geography concerning the area of influence of hydroelectric projects with potential above $10 \mathrm{MW}$, it denoted that there is a problem of adjustment in the aforementioned law. It was also observed that, in considering the Riaheg, after legal regulations, the EIA/EIR can thus be on the way to solve that problem. The whole approach was consolidated in defense of the thesis and that the document prepared by the hydroelectric entrepreneurs needs to recognize and adopt as an area of influence represented in the subject title and, above all, continue to be one of the requirements of Nepa, that is crucial to keeping Brazil ahead in these terms, on the international scene, certain that in any part of the globe such context is not yet being applied, according to the constant bibliography.
\end{abstract}

Keywords: Riaheg; Geography; environment; environmental policy; forecast impacts. 


\section{LISTA DE FIGURAS}

Figura 1 - Bacia hidrográfica do Rio Nilo .............................................................. 14

Figura 2 - Bacia hidrográfica do Rio São Francisco ..................................................... 15

Figura 3 - Uma proposta de área de influência real do ponto de vista da Geografia em território sergipano.............................................................................................................................55

Figura 4 - Representação gráfica da redução do volume de água do São Francisco, nas últimas

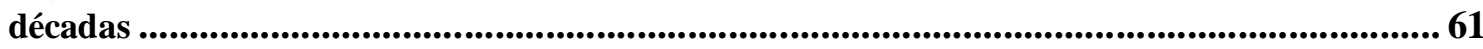

Figura 5 - Cachoeira Casca d'Anta (Rio São Francisco), Minas Gerais ......................... 89

Figura 6 - Mapa da classificação do curso do Rio São Francisco .......................................92

Figura 7 - Classificação do curso do Rio Nilo...........................................................95

Figura 8 - Mapa da Bacia Hidrográfica São Francisco - relevo e influência de massas de

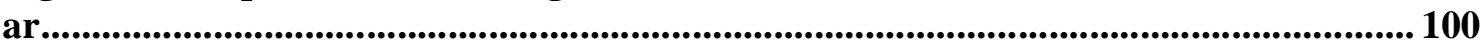

Figura 9 - Mapa do Clima da Bacia Hidrográfica São Francisco ...................................102

Figura 10 - Mapa da Bacia Hidrográfica São Francisco - Vegetação........................... 106

Figura 11 - Mapa da Bacia Hidrográfica do Nilo - Clima.............................................. 110

Figura 12 - Mapa da Bacia Hidrográfica do Nilo - Relevo........................................ 111

Figura 13 - Mapa da Bacia Hidrográfica do Nilo - Vegetação .......................................... 115

Figura 14 - Mapa da transposição do Rio São Francisco............................................ 127

Figura 15 - Estações de bombeamento dos eixos Norte e Leste da transposição a partir do Rio São Francisco.......................................................................................................... 130

Figura 16 - Organização espacial em volta da Represa Três Marias no Rio São Francisco, Três Marias/MG ........................................................................................................ 138

Figura 17 - Parreiral de uva, Petrolina/PE....................................................................... 139

Figura 18 - Organização espacial no Baixo São Francisco, platô de Neópolis/SE ........ 148

Figura 19 - Comparação do volume do Rio São Francisco através do afluxo (entrada) e fluxo (saída) dos reservatórios Sobradinho e Xingó, respectivamente............................. 162

Figura 20 - Representação da alteração da configuração espacial da Península Roseta situada no Delta do Nilo........................................................................................................ 173

Figura 21 - Representação da transformação do espaço geográfico na foz do Rio São Francisco 


\section{LISTA DE SIGLAS}

AI

AIA

AID

AII

Airehg

ANA

Chesf

Codevasf

Conama

Deso/SE

Dnpm

EIA

EIA/Rima

Enge-RIO

EPA

EUA

Fiep

GPS

Ibama

Ibge

Icmcb

Área de Influência

Avaliação de Impacto Ambiental

Área de Influência Direta

Área de Influência Indireta

Área de Influência Real de Empreendimentos Hidroelétricos do ponto de vista da Geografia

Agência Nacional de Águas

Companhia Hidro Elétrica do São Francisco

Companhia de Desenvolvimento dos Vales do São Francisco e do Parnaíba

Conselho Nacional do Meio Ambiente

Companhia de Saneamento de Sergipe

Departamento Nacional da Produção Mineral

Estudo de Impacto Ambiental

Estudo de Impacto Ambiental / Relatório de Impacto Ambiental

Engenharia e Consultoria S.A.

Environmental Protection Agency

Estados Unidos da América

Federação das Indústrias do Estado da Paraíba

Sistema de Posicionamento Global

Instituto Brasileiro do Meio Ambiente e dos Recursos Naturais Renováveis

Instituto Brasileiro de Geografia e Estatística

Instituto Chico Mendes da Conservação da Biodiversidade 


\begin{tabular}{ll} 
Km & Quilômetro \\
Lpnma & Lei de Política Nacional do Meio Ambiente \\
M & Metro \\
MAB & Movimento dos Atingidos por Barragens \\
MMA & Ministério do Meio Ambiente \\
MME & Ministério das Minas e Energia \\
MW & Megawatt \\
NE & Nordeste \\
Nepa & National Environmental Policy Act \\
Owos & Ozenka Wosdeisstwikha na Okruschakhuschtschukhu Ssredu \\
Rppn & Reserva Particular do Patrimônio Natural \\
Sisnama & Sistema Nacional do Meio Ambiente \\
UHE & Usina Hidrelétrica \\
Urss & União das Repúblicas Socialistas Soviéticas \\
UvP & Umweltvertäglichkeitprüfung \\
Zcit & Zona de Convergência do Atlântico Sul \\
\hline
\end{tabular}




\section{SUMÁRIO}

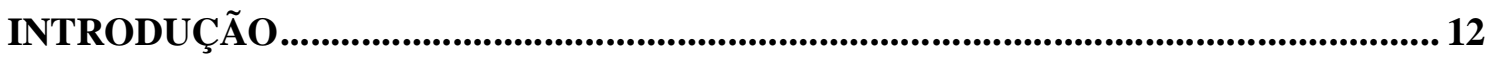

O Tema e a área de estudo no tempo e no espaço ....................................................... 12

O rumo do estudo e a base metodológica adotada ................................................. 17

1 ÁREA DE INFLUÊNCIA REAL DE EMPREENDIMENTOS HIDROELÉTRICOS

DO PONTO DE VISTA DA GEOGRAFIA (Airehg) ......................................................... 33

1.1 Em busca da definição da Área de Influência Real de Empreendimentos

Hidroelétricos do ponto de vista da Geografia................................................................ 34

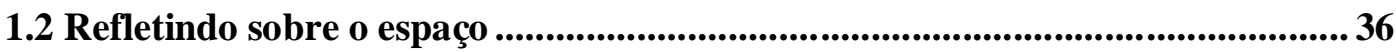

1.3 Critérios definidores da Área de Influência Real de Empreendimentos

Hidroelétricos do ponto de vista da Geografia a partir da análise da paisagem..... 44

2 O PROBLEMA DO AJUSTE NO ESTUDO DE IMPACTO AMBIENTAL (EIA) EM

RELAÇÃO À ÁREA DE INFLUÊNCIA REAL ......................................................69

2.1 A consideração da Área de Influência Real de Empreendimentos Hidroelétricos do ponto de vista da Geografia: um caminho visando solucionar o problema existente entre o que emana da Lei de Política Nacional do Meio Ambiente e o que prima o EIA/Rima

3 O RIO SÃO FRANCISCO: alguns aspectos semelhantes e comuns em relação ao Rio

Nilo

3.1 O espaço geográfico do Rio São Francisco em relação ao do Rio Nilo: uma interpretação da paisagem .................................................................................................. 86

3.2 A relação relevo, clima e vegetação........................................................................98

3.3 O espaço geográfico do Rio São Francisco e do Rio Nilo no alvo da modernização: consequência para seus baixos cursos ........................................... 118

3.4 Uma breve reflexão sobre a transposição do Rio São Francisco ..................... 125

3.5 A organização espacial em função das hidrelétricas e suas consequências: o caso do Rio São Francisco comparado ao do Nilo ......................................................... 135

CONCLUSÃO

REFERÊNCIAS BIBLIOGRÁFICAS ....................................................................... 179

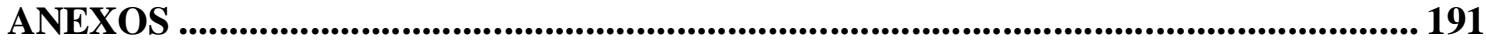




\section{INTRODUÇÃO}

\section{O TEMA E A ÁREA DE ESTUDO NO TEMPO E NO ESPAÇO}

A Área de Influência Real de Empreendimentos Hidroelétricos do Ponto de Vista da Geografia (Airehg) abrange o entorno desses tipos de empreendimentos, considerando a geografia do lugar. Posto isto, levando em conta a relevância do conceito e como se configura a referida área, é importante esclarecer que o entorno de todo o reservatório e tudo o que está ligado ao rio no qual houve interferência dá forma a tal espaço. Igualmente, entende-se que todo o espaço geográfico configurado em todas as possíveis relações do homem com a natureza forma a referida área, seja em termos de aspectos culturais, econômicos ou sociais, desde que haja qualquer relação destes com o rio interferido.

A forma como a área de influência real de empreendimentos hidroelétricos está sendo abordada se insere na área do estudo de previsão de impactos, área essa que se contextualiza na ciência geográfica. Por também ser interdisciplinar e fundamentada na Geografia que traz no seu bojo, o estudo do espaço resultado da relação sociedade - natureza, evidencia a preocupação com o problema ambiental enfrentado no mundo contemporâneo.

De acordo com Ab’Sáber (2006a, p. 36) “Qualquer erro de apreciação, avaliação e/ou previsão de impactos pode acarretar prejuízos irreparáveis para o futuro da região, da sociedade e do país". Por isso, se faz necessário analisar como a ação antrópica interfere sobre

a área estudada e como o seu espaço geográfico vem se organizando ao longo do tempo em função da existência dos empreendimentos hidroelétricos.

Nesse sentido, a Geografia revela que a maneira como o Estudo Prévio de Impacto Ambiental (EIA) adota a área de influência de empreendimentos hidroelétricos não se 
coaduna inteiramente com a consideração do relevante fator geográfico, isto é, o espaço total, que é de fundamental importância na previsão de impactos.

O espaço total pode abranger numa bacia hidrográfica, além de seu curso principal, seus tributários e parte de todos os seus divisores de água, como também as consequências nesse domínio territorial causadas pela intervenção humana em função da execução e operação de empreendimentos hidroelétricos. Do ponto de vista geofísico, merecem destaque as vertentes interiores da bacia hidrográfica principal.

Por essa razão, a área de influência em epígrafe revela-se como uma questão que pode ser resolvida a partir do ajuste das leis nacionais e internacionais de diretrizes do Estudo de Impacto Ambiental - Relatório de Impacto Ambiental (EIA/Rima), pois toda sua extensão sofre as consequências da relação da sociedade com a natureza, o que vem contrapor-se ao EIA que não considera o espaço total.

Cabe frisar que os impactos ambientais, consequências que atingem o meio ambiente por causa da ação humana, dão referência à dimensão do espaço, sobre o qual as transformações socioespaciais ${ }^{*}$ vêm ocorrendo nas duas bacias hidrográficas citadas a seguir. Mediante esses termos considerados variáveis, conforme adiante abordados, adotou-se como objeto de estudo a área de influência real de empreendimentos hidroelétricos do ponto de vista da Geografia.

A presente pesquisa situa-se principalmente no tempo em que o espaço geográfico da Bacia São Francisco, com destaque para seu baixo curso, sofreu expressivas mudanças no tocante aos aspectos naturais e socioespaciais, a partir de meados do século XX.

Tendo em vista a relação de tais mudanças à execução e operação dos empreendimentos hidroelétricos ali instalados, além de tal período se destacar numa corrida empreendedora, foi possível observar que, assim como no caso do rio brasileiro, no Egito (África), o Rio Nilo

(*) As mudanças de hábitos de vida da sociedade e de seu espaço. 
também passou a ser analisado com foco no baixo curso. Cabe frisar que, neste caso, um dos capítulos contempla uma abordagem comparativa em relação às semelhanças que há entre os dois rios, de modo a contribuir com o conceito do tema. $\mathrm{O}$ mapa a seguir representa a bacia hidrográfica do Rio Nilo.

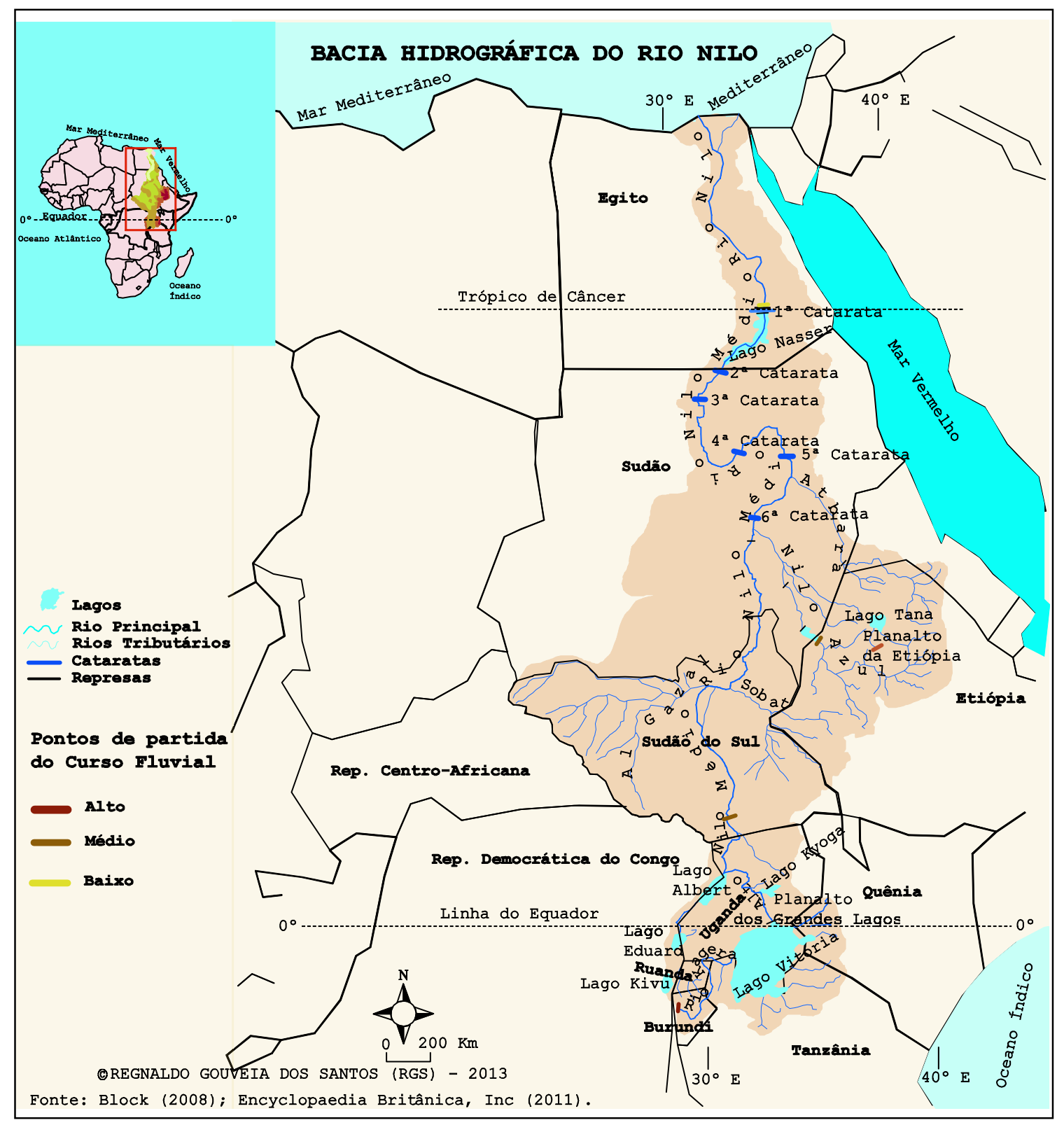

Figura 01. Bacia hidrográfica do Rio Nilo.

Durante o desenvolvimento da pesquisa, buscou-se fazer uma análise apurada sobre o Rio São Francisco, o que instigou comparar-lhe a um outro rio que apresentasse elementos semelhantes e em comum referentes ao seu espaço geográfico. Após observações, achou-se 
pertinente, portanto, abordar o espaço fluvial* do Nilo, em termos gerais, dando ênfase à paisagem do seu baixo curso, a jusante de Assuã. Por isso, cabe ressaltar que o estudo se desenvolveu de forma mais enfática ao longo da Bacia Hidrográfica Sãofranciscana, representada no mapa abaixo.

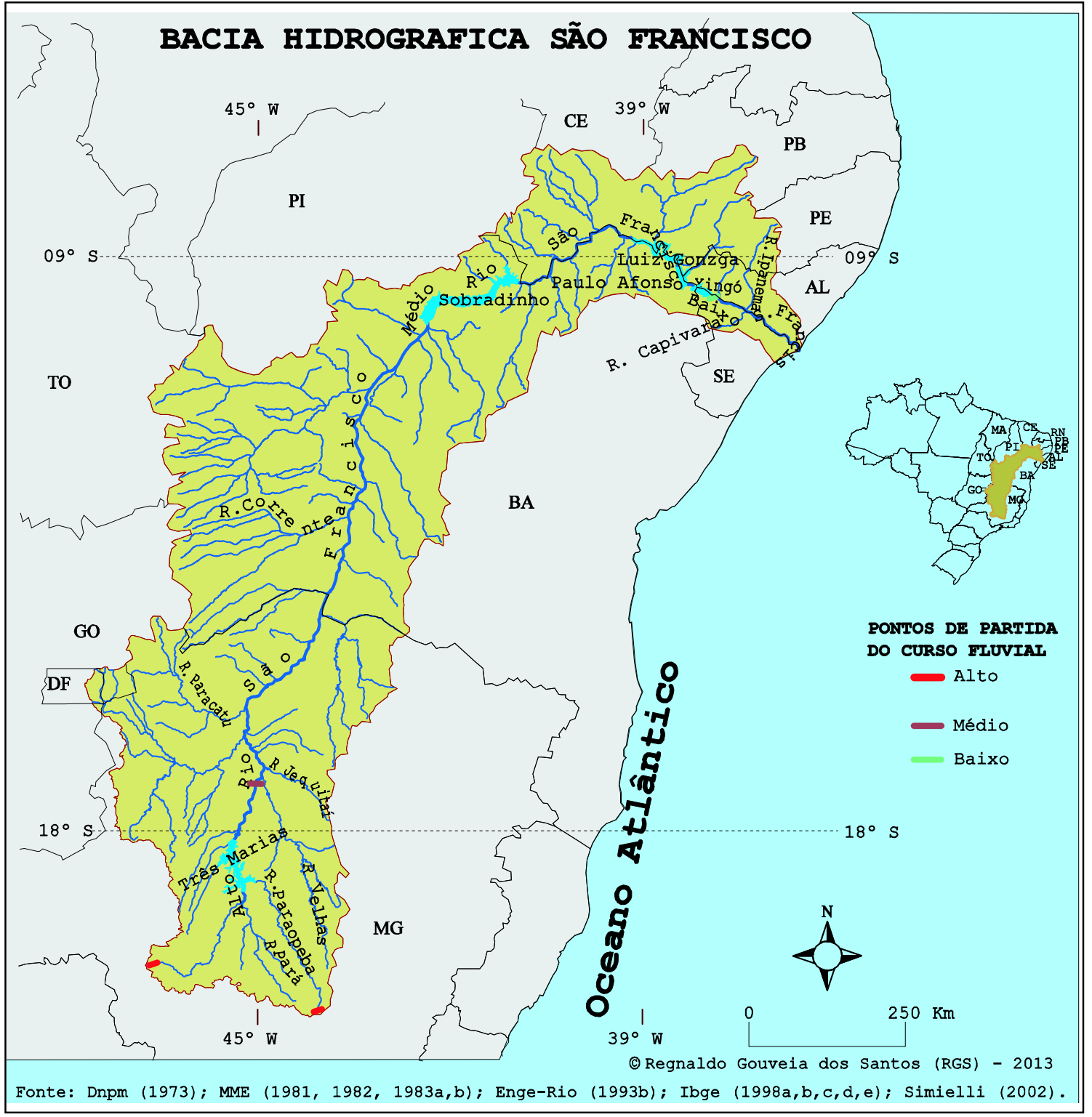

Figura 02. Bacia hidrográfica do Rio São Francisco.

No caso do São Francisco, a partir da década de 1960, até final do século XX, esse rio foi marcado por um período de construção de grandes barragens como a Represa Três Marias

(*) Dimensão espacial que envolve a relação existente entre os seres vivos com o rio e a natureza deste. 
(1962), após a primeira obra do Complexo Hidroelétrico Paulo Afonso (1945) que é de menor interferência em relação àquela represa, além de outras mais recentes como Sobradinho, Luiz Gonzaga (antiga Itaparica), Moxotó e Xingó, ao longo do rio até seu baixo curso.

Esse período marcou também o espaço fluvial do Rio Nilo, pois o tempo que se estendeu entre 1960 e 1970, trouxe expressivas mudanças a esse espaço devido à execução do empreendimento Alta Assuã, onde se formou o Lago Nasser que passou a operar para atender a várias funções, desde a geração de energia elétrica até destinar a água para a agroindústria e o abastecimento humano. O referido empreendimento localiza-se em Assuã (Egito), no baixo curso do rio, região em que os impactos socioambientais se alastram com maior notabilidade.

Observa-se que, nesse sentido, a partir da década de 1970, surgem no mundo atenções voltadas para a questão socioambiental, pois de acordo com Ab’Sáber (2006a, p. 32):

A reação da inteligência humana a esses processos agressivos de eliminação da vida na face da terra foi muito recente. Emergiram a partir da década de 70, com as colocações do Clube de Roma na reunião de Estocolmo (1972) e a introdução do conceito de ecodesenvolvimento.

No entanto, não é de se desprezar os aspectos de condições ambientais já observados muito antes, desde a década de 1920, engendrando preocupações a pesquisadores envolvidos com a causa do meio ambiente no mundo.

Eleger a bacia hidrográfica do Rio São Francisco como recorte espacial para interpretar a Airehg, deve-se à busca pelo aprimoramento do conhecimento empírico acumulado ao longo da vivência com esse espaço, além das experiências teórica, acadêmica e empírica que vêm sendo adquiridas nos últimos anos. A notabilidade da transformação socioespacial, a partir das intervenções no meio ambiente, tem como causa principal a existência e operação dos empreendimentos hidroelétricos ao longo do principal curso fluvial, fato que marcou a vida de quem habita as suas margens. Este é o fator crucial a instigar a busca de um caminho mais plausível através de estudos, nos quais se assegure, pelo menos, o senso de igualdade. Esse fator também conduziu a aspirar à academia, onde as ideias passaram a amadurecer por 
meio de importantes revisões bibliográficas brasileiras e estrangeiras, dando base teórica para proceder ao desenvolvimento do estudo por vias de uma metodologia adequada. Somando isso a alguns textos produzidos contemplando o tema, passou-se ao aprofundamento sobre a sua definição por meio da eleição dos objetivos e verificação de suas hipóteses.

Igualmente, comparar alguns aspectos semelhantes dessa bacia hidrográfica a outros do Nilo, remonta ao interesse de buscar respostas, em segunda instância, para a tradição de se fazer este vínculo com o Brasil, "Rio São Francisco: o Nilo brasileiro"; e, sobretudo, porque, com os resultados da pesquisa, foi possível observar várias semelhanças na organização do espaço geográfico desses rios, com destaque para seus baixos cursos.

Tendo em vista a comparação que se faz em relação aos dois rios, visando alcançar respostas criteriosas na perspectiva de contextualizar o tema abordado, é importante frisar que, se por um lado, comparar signifique diferenciar as circunstâncias das coisas, por outro, é possível usar a expressão para mostrar as semelhanças. Por isso, foi levada em conta a abordagem comparativa optando por trabalhar o que há em comum e semelhante entre os espaços elencados e deixando as diferenças em segundo aspecto.

\section{O RUMO DO ESTUDO E A BASE METODOLÓGICA ADOTADA}

Após realização da revisão da literatura instigada a partir de participações em eventos científicos em que textos referentes ao presente feito foram apresentados, o levantamento bibliográfico passou a elucidar o desenvolvimento do tema. Em função de uma reflexão feita sobre tal revisão, na qual o pensamento de Ab'Sáber (2006a) ganhou destaque a respeito do espaço total, resolveu-se, portanto, buscar interpretar o tema em epígrafe através da análise da paisagem, abordando, principalmente, a discussão fenomenológica no segmento da geografia cultural. 
Assim, refletir sobre a ideia desse autor ao considerar o espaço total, fez-se necessário reconhecer também que este representa um mosaico compreendendo observações geográficas cruzadas com diversos fatos ecológicos. Cabe frisar também que o fator interdisciplinar envolvendo o seu tema se resume essencialmente na observação da paisagem, levando em conta a historicidade através da análise do território de determinada região para entender a organização espacial do presente.

Nesse sentido, de acordo com Ab’Sáber (2004, p. 98, grifo nosso):

Há algum tempo, porém, o vocábulo [espaço total] tem sido utilizado para um fragmento do território regional que pode ser visto no contexto do presente, como resultado de uma longa elaboração histórica. Foi nessa condição que o conceito foi introduzido entre nós pelo saudoso Milton Santos. Mesmo assim, foi pouco, porque todo espaço regional é fruto de uma história geológica, geomorfológica, pedológica e hidrológica, modificada por sucessivas formas de atividades antrópicas; às vezes bastante perturbadoras.

Ou seja, interpretar o termo espaço total significa compreender a concepção da expressão geoecologia, pois de acordo com Ab’Sáber (2004, p. 98):

Uma noção geoecológica mais densa e espacialmente atenta, como a contida na noção de espaço total de fragmentos de um território, torna-se muito mais abrangente, já que atende ao mosaico de fatos participantes de qualquer área em estudo. Além disso, permite caracterizar os diferentes estágios em que se encontram os remanescentes dos ecossistemas naturais [...].

Vê-se, conforme a abordagem, que em função da noção de tal expressão residir na interpretação do referido espaço, a concepção deste abrange os aspectos naturais e sociais, razão pela qual se subentende aceitar como obrigação o reconhecimento do espaço total em todo e qualquer projeto empreendedor quando de seu desenvolvimento venha acarretar impactos ambientais. Em sendo o caso, é preciso refletir sobre os impactos ambientais já existentes ou que venham a ocorrer, para que o ser humano e o meio ambiente, em dado momento futuro, não sofram as consequências de tal interferência, como foram observados nos baixos cursos dos rios São Francisco e Nilo. Por exemplo, as desconfigurações naturais 
das fozes desses rios, no primeiro caso detectado no povoado de Brejo Grande/SE, Vila Cabeço, e no segundo, notáveis nas penínsulas Roseta e Damieta, Egito.

A pesquisa revela que tudo isso está relacionado à existência e operação dos empreendimentos hidroelétricos, tanto que, de acordo com Ab’Sáber (1991, p. 43):

[...] o reservatório de uma barragem é sempre uma agressão ao meio ambiente. Não há como sair disto. Qualquer tentativa de bloquear o caminho das águas e de retê-las por algum tempo, mesmo que extravasem pelas turbinas ou pelos ladrões da represa, é uma agressão. [...]. Assim, é necessário um máximo de bom-senso na apreciação da questão das barragens.

Por essa razão, tratando-se de interpretar o espaço total, é preciso considerar os espaços herdados da natureza e da cultura humana dotados de qualquer vínculo com o rio interferido, pois como bem observou Ab’Sáber (1991, p. 43): “A barragem não se insere em todos os casos numa natureza totalmente virgem, totalmente alheia à presença do homem e da história”.

A partir dessa análise, vai-se fazer uma interpretação do espaço total com base na ideia do citado autor, visando contextualizar o conceito da área de influência real de empreendimentos hidroelétricos do ponto de vista da Geografia. Por isso, em relação à concepção de âmbito espacial e conforme se denota ao longo do texto, para elucidar os fatos, tomou-se como base, principalmente, Ab'Sáber (2006a), entre outros autores pertinentes ao tema. Nessa concepção, o contexto espacial é capaz de retratar o que se busca com a definição e conceito do tema em epígrafe e se exprime com melhor clareza. Por conseguinte, de acordo com Ab’Sáber (2006a), é possível observar que, considerando o espaço total, prever impactos é um ato importante, visto que tem o potencial de esclarecimento no intuito de antever uma futura transformação do espaço. Porque também, os grupos esclarecidos, ao tomarem como base a previsão de impactos, se tornam uma força de pressão social. Dessa forma, em relação ao bom uso dos instrumentos legais, poderão trazer importantes benefícios para o meio 
socioambiental ${ }^{*}$, assim como um ordenamento territorial e, por meio deste, uma conservação ambiental adequada. Além de tudo, esse ato poderá testar a potencialidade da legislação disponível.

Desse modo, referida área de influência será mensurada, entre outros critérios, por meio das possibilidades da relação do homem com a natureza, levando em conta a análise dos impactos socioambientais do ponto de vista geo-histórico.

Em função da interdisciplinaridade do tema, cabe frisar que o aspecto biológico, qualidade da água, será abordado, o qual foi levantado através de informações presentes tanto na revisão bibliográfica, quanto nas entrevistas efetuadas na pesquisa de campo. Aqui também compete esclarecer que a presente pesquisa não trata, portanto, de um estudo limnológico. Todavia, isso não impede da referida abordagem ser realizada na perspectiva da previsão de impactos, conforme se realiza no campo da Geografia.

É importante ressaltar que não há nenhuma pretensão aqui de esgotar a discussão sobre o tema da pesquisa Airehg, mas que a sua conclusão venha ser o limiar de um caminho que, quiçá, um dia chegue ao tão almejado desenvolvimento sustentável, por meio de ajustes das leis nacionais e internacionais de diretrizes da regulamentação do Estudo Prévio de Impacto Ambiental - Relatório de Impacto Ambiental (EIA/Rima).

A partir desse momento geral da pesquisa, retomou-se uma nova revisão da literatura, fazendo um importante esforço no intuito de interpretar de que maneira os critérios adotados, assim como as características físicas do espaço geográfico e o impacto socioambiental, na análise da paisagem, dão o suporte da forma da Airehg. Nesse sentido, buscou-se mostrar, por exemplo, o caso analisado sobre alguns aspectos semelhantes e comuns observados, principalmente, nos baixos cursos dos rios São Francisco e Nilo. Todo esse esforço converge para o senso maior, entender de que maneira as características físicas do espaço geográfico e

(*) Dimensão do espaço geográfico que envolve o meio ambiente e a sociedade. 
os impactos ambientais e socioambientais configuram a área em mote, na perspectiva da geografia cultural.

Ratificam-se as assertivas acima de acordo com Corrêa e Rosendahl (1998) em função de que o geógrafo tem como tarefa decodificar o significado da paisagem, tendo em vista que esse objeto geográfico está em toda parte.

Em outros termos, a maneira com a qual se revelam os critérios adotados para tal contexto reside na geografia cultural. Por isso, a bacia hidrográfica foi considerada para a realização da abordagem das características físicas do espaço geográfico. Neste caso, levam-se em conta seus divisores de água, afluentes, subafluentes, o curso d'água principal e aspectos fitogeográficos. Além disso, o meio biogeográfico foi considerado, voltando-se mais para a percepção dos impactos ambientais com ênfase nos empreendimentos hidroelétricos e as consequências sobre o meio social. Desse modo, o impacto socioambiental caracterizou-se como importante variável da paisagem cultural.

Ao analisar este tipo de impacto, notou-se que o uso da água representa um dos critérios capazes de configurar a Airehg por meio das possibilidades da relação do homem na natureza.

Elencar esses critérios deve-se ao fato de que a sua conjugação no espaço geográfico se apresenta como possibilidades da relação do homem com a natureza e, dessa forma, é possível mostrar como se configura a Airehg. Da mesma forma, pode-se mensurar a dimensão espacial através da detecção dos impactos que alcançam as pessoas, de um modo ou de outro, tendo em vista os vínculos que elas possuem com os rios.

Nesse sentido, cabe frisar que adotar o uso da água como critério, entre outros, se fez necessário por esse ser um dos principais meios que resguardam os vínculos do homem com o rio, independentemente de onde ele se encontrar beneficiando-se com tal uso diretamente. Nota-se que, quando o uso é indireto, por exemplo, por meio do consumo de frutas cultivadas nas margens do São Francisco ou do Nilo, com suas águas, representa um impacto inferior ao 
que se refere como uso direto. No primeiro caso (leve-se em conta o São Francisco), as redes hidráulicas, principais vias de abastecimento, entre outros meios, ligam diretamente os beneficiados por tais redes aos rios. No segundo caso, o consumo estrangeiro das frutas cultivadas nos vales de tais rios, por meio da irrigação com suas águas, ganha destaque o exemplo representado a respeito do fator indireto.

Visando corresponder com os objetivos, foram levantadas hipóteses que estabelecem relações entre variáveis, de modo que, ao longo do desenvolvimento do estudo, se fez necessário ponderar sobre o que se segue:

a) A principal hipótese se baseia na seguinte investigação científica: como a Área de Influência Real de Empreendimentos Hidroelétricos do Ponto de Vista da Geografia se configura no espaço geográfico, levando em conta a paisagem natural e a paisagem cultural vinculadas a um rio interferido por empreendimento hidroelétrico, seja o São Francisco ou o Nilo, por exemplo.

b) As hipóteses secundárias se baseiam em: de que maneira os espaços geográficos dos baixos cursos São Francisco e Nilo revelam variáveis que constituem a referida área de influência? A Resolução Conama nº 01/86 determina que o EIA/Rima (custeado pelo empreendedor) considere a bacia hidrográfica ao delimitar a Área de Influência do empreendimento hidroelétrico com potencial acima de $10 \mathrm{MW}$. Todavia, há caso comprovado no Rio São Francisco, em que grande parte de seu espaço geográfico não foi levada em conta, apesar de sofrer impacto ambiental. Assim, o que se entende por esse descompasso, a partir do documento do empreendedor em relação à interpretação desse elemento espacial do ponto de vista da Geografia? Tendo em vista o seu processo histórico, em que implica o EIA/Rima considerar a Área de Influência Real de Empreendimentos Hidroelétricos do ponto de vista da Geografia? 
Ao mesmo tempo em que as hipóteses secundárias interrogam, estão repletas de respostas contempladas ao longo dos capítulos desenvolvidos e se coadunam sustentando a principal hipótese e respondendo às demandas desta. Desse modo, segundo Vieira (1991) a tese é resposta a uma indagação.

Com a análise desses questionamentos, passou-se a notar que suas respostas são fundamentais e razoáveis para contextualizar o que se busca com este estudo, sobretudo, seu cerne. Assim, não se hesitou em elencar os seguintes objetivos, almejando responder às questões das referidas hipóteses e visando a coesão do escopo da pesquisa:

a) contextualizar, sobretudo, o estudo proposto no campo da ciência geográfica na área da previsão de impactos ou beirando-a, abordando a paisagem como meio de interpretar as possibilidades da ação do homem na natureza, para revelar o conceito que se almeja;

b) especificar, neste caso, os critérios utilizados como variáveis para abordar e conceituar, respectivamente, as também variáveis da paisagem, características físicas do espaço geográfico e impacto socioambiental, que a estas se coadunam para definir a área de influência real de empreendimentos hidroelétricos do ponto de vista da Geografia;

c) conceituar a Área de Influência Real de Empreendimentos Hidroelétricos do Ponto de Vista da Geografia interpretando-a a partir das características físicas do espaço geográfico e do impacto socioambiental, embasando-se na análise da paisagem e considerando, portanto, em geral, alguns aspectos semelhantes e comuns notáveis nas bacias hidrográficas do São Francisco e do Nilo, enfatizando seus baixos cursos;

d) revelar que a falta de consideração da Airehg, por parte do EIA/Rima (cujo projeto o empreendedor é responsável por suas custas), se configura em um problema de ajuste na Lei de Política Nacional do Meio Ambiente do território brasileiro.

É importante ressaltar que a verificação das hipóteses exigiu o uso de técnicas e instrumentos cartográficos que auxiliaram a obter as informações da análise dos dados de 
vazão fornecidos pela Companhia Hidro Elétrica do Vale São Francisco (Chesf) e do sistema de abastecimento de água da Companhia de Saneamento de Sergipe.

Por isso, as entrevistas realizadas contemplam principalmente perguntas abertas e às vezes, mistas, dependendo do que se pretende alcançar com estas, uma vez que o alvo das entrevistas gira em torno de representantes institucionais e pessoas comuns com experiência de vida sobre o assunto abordado; em relação aos primeiros foram inquiridos desde aspectos políticos até específicos sobre o tema em epígrafe, enquanto que os últimos, de certa forma, penderam para uma história de vida. Esses procedimentos metodológicos (denotados nos questionários dos anexos), entre outros métodos utilizados no levantamento de dados, visaram alcançar respostas das questões investigadas a partir das hipóteses.

Nesse sentido, considerou-se a história de vida por “[...] ser um depoimento, isto é, não apenas um relato cronológico de acontecimentos, mas trazer em si a riqueza de sentimentos, opiniões e atitudes da pessoa que a relata [...]." (QUEIROZ, 2008, p. 86). Cabe frisar que o uso dessa técnica exige tempo, paciência e que o pesquisador traga, no bojo do seu conhecimento, experiência para bem administrar a execução da entrevista, porque "Assim, somente a experiência poderá estabelecer o tempo ótimo para cada caso.” (QUEIROZ, 2008, p. 94).

Proceder por esses dois meios na aquisição de informações significa estudar os caminhos, entre outros, pelos quais a análise científica se faz necessária para ratificar a metodologia da pesquisa. Revela também, em segundo grau, o senso democrático, sobretudo, do ponto de vista do modo de como fazer ciência segundo a decisão do pesquisador.

Nas pesquisas de campo foram utilizados equipamentos como: Sistema de Posicionamento Global (GPS), máquina fotográfica e filmadora (no caso do Rio São Francisco) e software de cartografia para interpretar os dados levantados tanto em relação ao rio brasileiro, quanto ao Rio Nilo. O primeiro serviu para levantar pontos visitados na área de 
estudo; o segundo auxiliou na interpretação visual da paisagem e nas entrevistas filmadas quando das visitas do campo; e o terceiro também de modo interpretativo, mas com uma dimensão maior por causa da escala, colaborou com a transmissão de informações a partir dos dados tabulados. Além disso, estes dados também estão representados nos gráficos e mapas, onde se sintetizam em informações.

Os EIA/Rima(s), relativos às áreas de influência, que datam da década de 1980 até os dias atuais se incluem aos documentos estudados.

A importância do trabalho de campo convergiu para as possibilidades de conferir indagações levantadas nas hipóteses, entre outros fatores como a observação empírica do espaço da área de estudo, num contexto empírico. Por exemplo, o uso dos instrumentos acima citados colaborou com tal observação mediante as atividades de campo que fizeram parte de um método mais abrangente, pois não se limitou à metodologia específica predominante no presente feito. Ou seja, a cada visita ao campo as atividades desenvolvidas valorizaram tanto a teoria adquirida na revisão da literatura, quanto à empiria que foi se confirmando por meio da análise do espaço presente e, para sua melhor compreensão, considerando também o passado.

Posto que o problema proposto se apresenta de modo objetivo, é relevante chamar a atenção para o que bem observou Lage (2002, p. 10): “A teoria do conhecimento é o ramo da filosofia voltado para a relação entre o pensamento e as coisas, a consciência (interior) e a realidade (exterior), o entendimento e a realidade, em suma, o sujeito e o objeto do conhecimento". A lucidez que a autora traz sobre o sentido de sujeito e objeto é de fundamental importância para a elucidação do contexto do presente estudo e a compreensão do leitor a este respeito.

Sabendo-se que "A característica distintiva do método é a de ajudar a compreender, no sentido mais amplo, não os resultados da investigação científica, mas o próprio processo de investigação." (LAGE, 2002, p. 11). Por isso, os critérios adotados passam por um processo 
de descrição até alcançar a discussão que lhes envolve dentro da investigação científica ao atingirem a detecção de correlações. Noutros termos, esta se ratifica na fenomenologia da Geografia onde é possível compreender as possibilidades da relação do homem com a natureza, pois como bem observou Sauer (1998, p. 22), “Os objetos que existem juntos na paisagem existem em inter-relação". As análises da bacia hidrográfica e do espaço geográfico serão o ponto de partida para interpretar os critérios definidores dos limites territoriais, abarcando as possibilidades da ação do homem na natureza, congruentes a tais variáveis pertencentes à paisagem natural ou cultural, assim como o relevo, o curso d'água e qualquer que seja a relação direta do homem com o rio através de seu uso.

Vê-se que esse contexto perpassa por um segmento do pensamento geográfico que se embasa na geografia cultural. Esta, segundo Claval (1974, p. 132), “[...] es la conclusión de uno de estos procedimientos, aquel que pretende una explicación histórica para la geografía de las distribuiciones humanas".

Interpretar a Área de Influência Real de Empreendimento Hidroelétrico do Ponto de Vista da Geografia (Airehg) decorre de duas premissas fundamentais que dizem respeito ao caráter espacial e à natureza das atividades que se localizam no mesmo espaço. A primeira dá referência ao meio físico, entre outras possibilidades, onde se localizam as atividades, por exemplo, as características do espaço geográfico. A segunda presume que as atividades neste localizadas dão basicamente o suporte (as possibilidades da relação do homem com a natureza) da compreensão da dimensão que o impacto socioambiental pode alcançar. Com base nessas premissas, percebe-se que a relação das atividades mantidas com o espaço pode ser socioambiental. Isto é, significa representar vínculos entre o sujeito e o objeto nas mais diversas possibilidades da ação humana com o meio ambiente.

Reiterando que meio ambiente é o que envolve os seres vivos e abrange tudo em sua volta. Segundo Sánchez (2006, p. 18, 19): 
O conceito de 'ambiente', no campo do planejamento e gestão ambiental, é amplo, multifacetado e maleável. Amplo porque pode incluir tanto a natureza como a sociedade. Multifacetado porque pode ser apreendido sob diferentes perspectivas. Maleável porque, ao ser amplo e multifacetado, pode ser reduzido ou ampliado de acordo com necessidades do analista ou interesses dos envolvidos. [...].

Nesse sentido, a interpretação legal do conceito de 'ambiente' é determinante na definição do alcance dos instrumentos de planejamento e gestão ambiental. Em muitas jurisdições, os estudos de impacto ambiental não são, na prática, limitados às repercussões físicas e ecológicas dos projetos de desenvolvimento, mas incluem também suas conseqüências nos planos econômico, social e cultural.

É fundamental trazer à luz deste estudo os pontos de vista de importantes responsáveis pela disseminação do pensamento da geografia cultural no mundo, haja vista que a Airehg, neste caso, é abordada pendendo para essa área do campo da Geografia.

No início do século XX, década de 1930, Carl O. Sauer, importante estudioso da Geografia, nomeadamente alemã e francesa, transmitiu, através de suas reflexões, uma preocupação com essa ciência que se dividia, pois tal divisão a ameaçava destinando-a a um fosso. Em tal divisão ele ressaltou a geografia humana e a geografia cultural, mas esclareceu também que a denominação é usual, porém, não sendo exclusiva.

Mediante isso, segue a busca pelo entendimento da abordagem do tema em epígrafe. Para Sauer (2003, p. 25):

A geografia cultural implica, portanto, um programa que está integrado com o objetivo geral da geografia, isto é, um entendimento da diferenciação da Terra em áreas. Continua sendo, em grande parte, observação direta de campo baseada na técnica de análise morfológica desenvolvida em primeiro lugar na geografia física. Seu método é evolutivo, especificamente histórico até onde a documentação permite e, por conseguinte, trata de determinar as sucessões de cultura que ocorreram numa área.

Anos mais tarde surge uma percepção representando novos rumos da geografia cultural, tanto que segundo Cosgrove e Jackson (2003, p. 136):

Uma possível definição dessa 'nova' geografia cultural seria: contemporânea e histórica (mas sempre contextualizada e apoiada na teoria); social e espacial (mas não reduzida a aspectos da paisagem definidos de forma restrita); urbana e rural; atenta à natureza contingente da cultura, às ideologias dominantes e às formas de resistência. Para essa 'nova' geografia a cultura não é uma categoria residual, mas o meio pelo qual a mudança social é experienciada, contestada e constituída. 
Segundo Claval (2007, p. 219), a extensão que interessa aos geógrafos “[...] é feita de meios de vida com os quais os homens estabelecem as necessárias relações ecológicas". Acrescentem-se aí os ganhos e ou as perdas de valores constituídos ao longo do tempo sob a égide dos quais é possível mensurar o espaço que lhes abarca.

Nesse sentido, por um lado, é razoavelmente válido citar que "os fatos culturais interessam à geografia porque o espaço e o ambiente intervêm nos processos de transmissão e constituem um dado essencial daquilo que se transmite de uns para os outros." (CLAVAL, 2002, p. 142). Com essa concepção, pode-se compreender como se constitui o espaço representado na dimensão que o impacto socioambiental alcança.

Por outro lado, na incessante busca por interpretar o espaço total, essencialmente, “[...] é preciso realizar uma trajetória entre o mundo físico, o mundo geoecológico e o biótico regional, culminando nas apreciações do delicado e complexo problema das ações antrópicas cumulativas, que responderam pela conjuntura e dinâmica do chamado espaço total regional." (AB'SÁBER, 2005, p. 98).

Em última análise, é essa a concepção de base em que a presente pesquisa se fundamenta, ora de um modo geral, ora enfatizando a representação espacial pelas possibilidades da ação antrópica sobre a natureza como em alguns aspectos geomorfológicos, o curso e volume do São Francisco, por exemplo, buscando interpretar o citado "espaço total", visando ratificar a Airehg. Referir-se a um modo geral, deve-se ao fato de que, certamente, um único pesquisador dificilmente conseguiria, no desenvolvimento de uma única pesquisa em menos de cinco anos, criar a teoria do citado termo, por abarcar vários subcampos da Geografia e até da Biologia, como o foi legado à ciência geográfica por Ab’Sáber. É importante ressaltar que, inegavelmente, esse autor já imprimia parte do senso de tal espaço, segundo seu jeito de análise, ainda em meados do século XX, na obra "A Geomorfologia no Brasil” (AB’SÁBER, 1958), entre outras, de sua autoria. 
Diante de todo esse contexto, é preciso levar em conta que, de acordo com Corrêa (2003, p.172), “Insistimos que não são os objetos, nem um dado recorte temporal, passado, presente ou futuro, que definem a geografia cultural, distinguindo-a dos demais subcampos da geografia”. O que define a geografia cultural, só podem ser os aspectos fenomenológicos de tal ciência, capazes de promover as correlações entre o homem e a natureza. O senso fenomenológico está ilustrado no que observaram Bobek e Schmithüsen (1998, p. 75): “A geografia não se limita à observação e à descrição do visível, ainda que parta delas, mas pretende compreender a natureza do conjunto dos elementos constitutivos do âmbito que, com certa impropriedade, se denomina superfície terrestre".

Assim, é indispensável frisar que, de acordo com Corrêa e Rosendahl (1998, p. 9), "O trabalho em pauta é também uma contribuição daqueles interessados em questões ambientais, qualificando-se dentro de uma corrente que, na geografia, é conhecida como a das relações homem-natureza e da qual a paisagem é a expressão fenomênica mais contundente".

Tendo em vista que, conforme Berque (1998, p. 84, grifo do autor), "Entendo aqui a geografia cultural como o estudo do sentido (global e unitário) que uma sociedade dá à sua relação com o espaço e com a natureza, relação que a paisagem exprime concretamente". Razão pela qual é possível concordar que "O impacto das culturas sobre o espaço humanizado não se limita à paisagem.” (CLAVAL, 2007, p. 318).

Por exemplo, as consequências que o povo ribeirinho, habitante tanto das margens do São Francisco, quanto do Nilo, sofreu por causa da execução e operação dos empreendimentos hidroelétricos através desses rios representam um impacto que transcendeu a paisagem. Nesse sentido, é relevante destacar as duas premissas a seguir.

Primeiramente, significa dizer que o impacto ambiental observado engendrou consequências entre os habitantes ribeirinhos, afetando o sentido que eles davam às relações com seu meio. O impacto ambiental acarretou, portanto, outro impacto que atingiu 
diretamente o conjunto de pessoas que habitavam as margens dos rios. Este impacto denominado socioambiental se difere do primeiro em função de sua natureza, já que aquele se caracteriza por alterar o meio ambiente, enquanto o segundo afeta a pessoa (ser social) nas suas relações com esse meio. Embora este impacto alcance outra dimensão, além da paisagem natural, por não ser matéria (física) dessa configuração espacial, é carregado de fatores fenomenológicos capazes de formar espaço mensurável, pelo menos em aspecto territorial. A distância que o ribeirinho percorria de seu lar até o ponto que desenvolvia sua relação com o rio, resulta na forma de seu espaço relacional.

Em segundo lugar, igualmente, pode-se entender como espaço, a dimensão do resultado de todo e qualquer fator que impossibilite a relação de tal pessoa com o rio ou lhe resulte possibilidades de natureza parecida. Note que aqui diz respeito à relação do sujeito com o objeto, ou seja, no primeiro caso a pessoa percebeu a existência de espaço em função do tempo e sentimento ao percorrer até seu destino, isto é, a várzea, de onde obtinha seu sustento. No entanto, não se trata do espaço físico da área que ele percorre na paisagem, mas do que se forma a partir dos valores agregados (sentidos que ele assume) ao contemplar os elementos de sua percepção, da natureza, guardados em sua memória, valores esses que não são matérias físicas, porém, passíveis de formas por força de sua memória e costumes, agora afetados.

É imprescindível destacar que o ribeirinho do Baixo São Francisco, nascido na década de 1950, pode se referir que, de 1970 até meados da década de 1990, período em que o último empreendimento hidroelétrico desse rio entrou em operação, a maneira como ele se relacionava com o rio, considerando todos seus valores culturais, se engendrava de uma forma diferente da atual, nos dias de hoje. Apesar disso, todos que vivenciaram o período podem reconstituir referido espaço em sua memória.

A segunda premissa, anteriormente destacada, em nada difere da primeira, no que concerne à sua essência, pois é o contexto fenomenológico geográfico que conduz à 
interpretação espacial nas duas premissas. Por exemplo, a execução e operação dos empreendimentos hidroelétricos ao longo do Rio São Francisco, culminando com o de Xingó no baixo curso resultaram, dentre outros fatores, no impacto socioambiental. Entre outras maneiras que este se revela na vida do povo do lugar, ganha destaque na representação dos valores constituídos ao longo do tempo na condição da relação com o meio existente.

A relação ligando as pessoas ao rio constituiu-lhes vínculos de afetividade, de costumes, de relacionamento com a natureza, a partir das suas atividades laborais desde o cultivo até a colheita de arroz principalmente, entre outras plantações (cultivadas em menor quantidade) como feijão, milho, verdura, quando do ciclo de cheias naturais. O fator existência e operação dos referidos empreendimentos, principalmente o do último, acarretou impactos ambientais que impossibilitaram a relação dessas pessoas com o rio como tal ocorria. O fundamental do que se trata não é apenas esse fator, mas, sobretudo, a dimensão que essa configuração de impacto socioambiental alcança. Ou seja, até mesmo a Represa Três Marias, localizada no alto curso, tem sua parcela de participação mesmo que indireta como na causa desse impacto, além dos vários outros empreendimentos, culminando com o de Xingó.

Percebe-se que a dimensão espacial, a partir do ponto de interferência até onde o impacto alcançou, engendrando as outras consequências, contribui com esse contexto, ou seja, não se limita ao espaço físico somente, mas abarca também o sentido que as pessoas atribuem às relações com o meio e é desse modo que acontece a transcendência da paisagem. Assim, a Airehg se configura de acordo com os critérios adotados que ratificam suas variáveis, dentre as quais aqui se trata de uma, o impacto socioambiental.

Desenvolver o contexto do presente estudo justifica-se na consideração de que, de acordo com Claval (1997, p. 89):

A geografia cultural está associada à experiência que os homens têm da Terra, da natureza e do ambiente, estuda a maneira pela qual eles os modelam para responder às suas necessidades, seus gostos e suas aspirações e procura compreender a maneira como eles aprendem a se definir, a construir sua identidade e a se realizar. 
Ou seja, essa foi a metodologia adotada para alcançar o desenvolvimento do estudo através de suas análises, conceitos e definições almejados, para, finalmente, afirmar suas hipóteses.

Do mesmo modo, as diferentes interpretações das características físicas do espaço geográfico e da dimensão que o impacto socioambiental pode alcançar, possíveis a partir da leitura realizada, pertencendo a subcampos incumbidos da Geografia, se ratificam na abordagem geo-histórica. Dito de outro modo, esta abordagem tem como referência a análise a respeito da ação humana no espaço geográfico e no tempo dentro do contexto da Geografia, de maneira que o referido tempo se apresenta como possibilidades de espaço. Em última análise, a metodologia com a qual aqui se debruça para interpretar o "espaço total" que abrange a abordagem dos critérios elencados na presente pesquisa se apresenta como uma das possibilidades da ciência Geografia. 


\section{1 ÁREA DE INFLUÊNCIA REAL DE EMPREENDIMENTOS HIDROELÉTRICOS DO PONTO DE VISTA DA GEOGRAFIA (Airehg)}

Neste momento do estudo, firmou-se o cerne da pesquisa a partir de uma reflexão sobre o espaço, no sentido de trazer argumentos para conceituar o presente tema. Igualmente, após esse exercício, foram eleitos critérios a partir da análise de características do espaço físico e do impacto socioambiental observado por meio da concepção da geografia cultural, bem como analisando a paisagem no empenho de definir o tema em epígrafe. Fez-se um esforço em interpretar referida área de influência, considerando, mormente, a geo-história, mas sem deixar de lado a configuração socioespacial ${ }^{*}$ que vem se confirmando e dando sinais de um novo arranjo prospectivo do território das margens do Rio São Francisco.

$\left(^{*}\right)$ A forma como a sociedade se organiza no seu espaço (ou território) e como este se organiza a partir da ação humana. 


\subsection{EM BUSCA DA DEFINIÇÃO DA ÁREA DE INFLUÊNCIA REAL DE EMPREENDIMENTOS HIDROELÉTRICOS DO PONTO DE VISTA DA GEOGRAFIA}

A área de influência real de empreendimentos hidroelétricos, do ponto de vista da Geografia, configura-se como um espaço (ou subespaço), o qual abrange o entorno desses empreendimentos, levando em conta a geografia do lugar em que os impactos ambiental e socioambiental foram detectados. O fator delimitador de tal área não é apenas o espaço físico, mas sim este somado às possibilidades da relação do homem ou dos seres vivos em geral com a natureza ou com o meio ambiente, desde que todos esses se apresentem atingidos pelos impactos mencionados. Dar referência à natureza se deve ao fato de uma abrangência universal, enquanto que, no caso do meio ambiente se faz perceber o espaço local, sabendo que alguns seres vivos não têm a mesma condição de movimentação espacial igualmente ao homem.

Na expectativa de conceituar referida área de influência, considerando a dimensão espacial dos impactos ambiental e socioambiental, resolveu-se realizar a abordagem que segue conforme a bibliografia inerente ao tema em epígrafe.

De acordo com Ab'Sáber (2006a, p. 30, grifo do autor):

A gênese do espaço - considerado de um modo total - envolve uma análise da estruturação espacial realizada por ações humanas sobre os atributos remanescentes de um espaço herdado da natureza. Por essa razão, há que conhecer o funcionamento dos fluxos vivos da natureza (perturbados mas não inteiramente eliminados) e toda a história e formas de ocupação dos espaços criados pelos homens.

Daí por que, na previsão de impactos, é preciso considerar também os valores do povo de cada lugar assolado pelos impactos em questão, os quais constituem sua história e identidade cultural, social.

Pensando em um conjunto de elementos, dentre tantos outros que compõem esse espaço, se encontra a bacia hidrográfica, no âmbito do que está sendo tratado, e nesse 
contexto o homem, parte integrante desse cenário, quer seja beneficiando-se ou sendo prejudicado pela ação de outros homens. A partir desta situação, a ocupação dos espaços (local e regional) apresenta-se como a transformação possível da estrutura espacial. No que concerne à referida transformação, vê-se que é preciso haver um arranjo espacial, de certa forma, bem organizado para que a sociedade como um todo possa realizar o desenvolvimento social, econômico e ambiental, de modo que haja uma imbricação envolvendo esses três meios.

Assim, todo o espaço interferido pela execução e operação de empreendimentos hidroelétricos está inserido na Airehg, principalmente os pontos atingidos por impactos socioambientais, além de todos os fluxos fluviais ou lacustres e territórios que têm alguma conexão com o rio principal da bacia hidrográfica, a jusante.

Significa dizer que os rios e lagos a jusante de tais empreendimentos fazem parte de referida área, desde que sofram o refluxo do rio principal. Contudo, ainda que um território esteja inserido na bacia contribuinte, mas na margem do fluxo fluvial interferido, isso não quer dizer que não faça parte daquela área.

É relevante também ressaltar que, dependendo do relevo de determinados pontos dos cursos, os rios afluentes situados a jusante dos reservatórios em questão devem ser levados em conta do mesmo modo. Para isso, é preciso atender ao critério de que o leito principal esteja alcançando a foz desses com uma vazão abaixo do normal, comparada ao período da execução do empreendimento instalado. Por essa razão, seus contribuintes não terão os níveis de água naturais em suas fozes, muitas vezes de planícies, se o principal fluxo não estiver, por sua vez, com vazão também natural (dentro da normalidade em relação ao período que antecede o evento empreendedor). Além disso, neste caso, qualquer poluição química que o rio principal vier a sofrer será causa de vulnerabilidade de seus tributários por força natural através do fluxo da fauna tanto fluvial, quanto a que se apresentar às suas margens. 
De acordo com Unger (2001, p. 123), “O preservar genuíno tem uma dimensão positiva, ativa, e acontece quando deixamos algo na paz de sua própria natureza, de sua força originária". Pensar nessa concepção, relacionando-lhe às condições em que se encontra o espaço geográfico, norteia o observador a entender como deve ser considerada a área de influência real de empreendimentos hidroelétricos. Ou seja, a força da natureza, a qual não é imposta por ação humana, é que conduz o limite das formas dos fenômenos ocorridos ao longo do espaço fluvial, sua bacia hidrográfica, ou até além desta.

\subsection{REFLETINDO SOBRE O ESPAÇO}

O tema da presente pesquisa traz como problemática, a dimensão que os impactos ambientais e socioambientais podem alcançar a partir de empreendimentos hidroelétricos e, como se percebe, diz respeito a uma abordagem espacial. Por isso, o espaço será analisado em aspectos relacionais, a partir de determinado ponto (o(s) empreendimento(s) hidroelétrico(s)) em relação à sua abrangência (a área de influência real) circunstancial.

Por essa razão, é fundamental entender o que é tal espaço, visto que sua abrangência está ligada a si mesma. Depois da concepção espacial contextualizada e de abordá-la na análise da paisagem, interpretando o "espaço total”, a área em epígrafe será conceituada.

Desse modo, pode-se remeter à ideia de espaço por meio dos pensadores a seguir. Apesar de eles pertencerem a correntes diferentes, a abordagem que se faz é relevante para o contexto da presente pesquisa, a saber:

Segundo Newton (1990, p. 7):

O espaço absoluto, em sua própria natureza, sem relação com qualquer coisa externa, permanece sempre similar e imóvel. Espaço relativo é alguma dimensão ou medida móvel dos espaços absolutos, a qual nossos sentidos determinam por sua posição com relação aos corpos, e é comumente tomado por espaço imóvel; assim é a dimensão de um espaço subterrâneo, aéreo ou celeste, determinado pela sua posição com relação à Terra. Espaços absoluto e relativo são os mesmos em configuração e magnitude, mas não permanecem 
sempre numericamente iguais. Pois, por exemplo, se a Terra se move, um espaço de nosso ar, o qual relativamente à Terra permanece sempre o mesmo, em um dado tempo será uma parte do espaço absoluto pela qual passa o ar, em outro tempo será outra parte do mesmo, e assim, entendido de maneira absoluta, será continuamente mudado.

A partir do penúltimo ponto da citação, nota-se que o autor pode colaborar com a noção de espaço total, porém, não é possível concordar com toda sua ideia sobre a noção de espaço, pois se "o espaço relativo é móvel” (NEWTON, 1990, p. 7) o absoluto não pode permanecer imóvel. Além de tudo, sabe-se que o interior (magma) da Terra não é imóvel e impulsiona as placas tectônicas, engendrando o movimento dessas, as quais compõem a estrutura geológica, com destaque para a esfera inorgânica do Planeta Terra, a litosfera. Já as partes (coisas internas ou externas da Terra) que compõem o Universo, também se movimentam, mas por ser infinito, o espaço universal ainda não foi descoberto de fato.

Assim, acredita-se que o espaço absoluto só pode ser um todo composto por partes, ora se afirmando para formar o seu todo (individual) em determinados momentos, ora se negam (quando deixam de ser o todo (individual)) para formar o todo absoluto, o universal. Quanto à discordância sobre a noção de espaço assegurada por Newton (1990), faz jus o seguinte: se não fosse do autor a afirmação no segundo ponto de sua citação acima, seria possível concordar com ele. Ou seja, haveria de se concordar com Newton (1990) se ele tivesse afirmado que até o espaço relativo é imóvel, independentemente da sua dimensão ou medida. No que se refere a isso, ainda que o processo de preencher uma bola (de assopro) de borracha bastante flexível esteja em movimento conforme a ação do sopro (constituído por ar) que preenche a bola, a cada instante, relativamente, ao assopro e ou à forma que referido objeto se constitui em dimensão ou medida, representa o espaço imóvel. Acredita-se, com isso, que a "coisa" (o ar) se movimentou e pode continuar se movimentando dentro e conforme as condições do espaço, neste caso, a bola, porém, o espaço (a sua forma) não se movimentou, nem se movimenta em nenhuma condição.

Para Kant (1980, p. 42): 
a) $\mathrm{O}$ espaço de modo algum representa uma propriedade de coisas em si, nem tampouco estas em suas relações recíprocas; isto é, não representa qualquer determinação das mesmas que seja inerente aos próprios objetos e permaneça ainda que se abstraia de todas as condições subjetivas da intuição. Com efeito, nem determinações absolutas nem relativas podem ser intuídas antes da existência das coisas às quais dizem respeito, e por conseguinte também não a priori.

b) O espaço não é senão a forma de todos os fenômenos dos sentidos externos, isto é, a condição subjetiva da sensibilidade unicamente sob a qual nos é possível intuição externa. Ora, visto que a receptividade do sujeito ser afetado por objetos necessariamente precede toda intuição destes objetos, compreende-se como a forma de todos os fenômenos pode ser dada na mente antes de todas as percepções efetivas, por conseguinte a priori, e como ela, enquanto uma intuição pura na qual todos os objetos têm que ser determinados, pode conter, antes de toda a experiência, princípios das relações dos mesmos.

Nessa concepção, o espaço é como a forma a priori das coisas. Ou seja, a intuição sobre o espaço se antecipa em relação ao objeto observado. Pode-se afirmar que isso é fato, mas o que dizer do espaço futuro e pretérito ao sujeito? Neste caso, é necessário levar em consideração que o espaço não deixará, nem deixou de existir. Tal questionamento se remete ao fato de que a intuição se dá no imediatismo, essa não se confirmou, portanto, no passado, nem se confirmará no futuro, mas sim apenas no presente. Quanto à confirmação no passado, sabe-se que o sujeito (indivíduo racional) existiu (passado) em algum momento, razão pela qual a intuição jamais poderia existir senão no presente e em relação à confirmação no futuro, este nunca será alcançado a menos que na forma de tempo presente (a única possibilidade da intuição).

De acordo com Hegel (1936, p. 240, grifo do autor), “O espaço é a justaposição do todo ideal porque é o ser fora de si mesmo e simplesmente contínuo, porque esta exterioridade é ainda de todo abstrata, e não tem em si nenhuma diferença determinada". A maneira com que o autor discute a concepção de espaço demonstra que determinadas partes podem constituir um todo, o próprio espaço. Significa dizer que o espaço também pode ser subdividido por coisas que necessariamente lhe formam.

Diante da concepção espacial que aqui está sendo tratada, não se pode deixar de frisar que, fundamentalmente, o espaço tem relação com o tempo e, certamente, essa relação 
acontece, entre outros fatores, por força da relação entre o sujeito (possuidor da intuição) e o objeto. Sendo que, tanto o espaço, quanto o tempo, têm suas particularidades, pois como bem observou Minkowisk (1989, p. 94):

Lugares e tempos nunca se apresentam à nossa observação senão unidos entre si. Nunca se observa um lugar sem ser num determinado instante, nem um instante sem ser num determinado lugar. Mas continuarei a respeitar o dogma de que o espaço e o tempo têm significado independente.

É importante esclarecer que sujeito, consciência partida do indivíduo, é a referência dada ao indivíduo capaz de perceber o objeto (o objeto em si, desde que pensado) e este, por sua vez, se refere ao sujeito, de maneira que um depende do outro, reciprocamente, pois de acordo com Adorno (1969, p. 1, grifo do autor):

[...] o indivíduo humano singular - tão logo se reflete de alguma maneira sobre ele numa forma conceitual universal enquanto indivíduo, e não se tem em mente só o esse aí qualquer de um homem particular 'besonderen Menschen' - transforma-se já num universal, à semelhança do que fica explicitado no conceito idealista de sujeito; [...] É que, de certa maneira, os conceitos de sujeito e de objeto - ou melhor, aquilo a que se referem - têm prioridade sobre qualquer definição.

Em geral, os autores trazem a concepção de espaço tanto num sentido absoluto, quanto relativo, apesar de críticas notáveis entre eles e algumas divergências de pensamentos. Porém, nada que refute suas ideias por completo. Também foi possível observar que os autores apresentam uma mesma linha de pensamento, o espaço é a forma do objeto (coisa) intuído pelo sujeito. Isso não quer dizer que a concepção Kantiana é a mais conveniente a ser tratada neste caso, mas será a colaboração que todos têm a oferecer, pois se nenhum deles fosse criticado, a discussão espacial talvez não existisse como está posta.

Essa discussão que prevalecerá no desenrolar deste feito, girará em torno da concepção de Ab'Sáber (2006a), de forma que será considerado o espaço total, o que abrange a organização complexa de uma determinada área.

Depois de todo apontamento supracitado, cabe frisar que a área de importância aqui considerada, em termos de aspecto físicoespacial, é a bacia hidrográfica que será abordada na 
direção de sua complexidade. Muito além disso, qualquer outro espaço que transcender a bacia hidrográfica onde ocorreu o impacto ambiental a partir de empreendimentos hidroelétricos, desde que seja afetado por impactos ambientais ou socioambientais, por causa da execução e operação de tais empreendimentos, tem a mesma importância. Isto é, as possibilidades de relação do homem com a natureza inserem-se, sobretudo, nesse contexto.

Tal complexidade abrange, entre outras circunstâncias, desde as relações existentes entre a ação humana sobre a bacia hidrográfica e as inter-relações que há nesse sistema entre si, assim como a ligação de um afluente com seu rio principal e a necessidade dos seres se relacionarem com este, até as possibilidades de consequências acarretadas pela ação humana na área da bacia hidrográfica, com capacidade de se alastrarem além dessa área. É nesses aspectos que a concepção de espaço aqui permeia, ou seja, não se limita ao meio físico, mas abrange as possíveis relações com outros meios, pois como bem observou Ab'Sáber (2006a, p. 35):

Entendem-se por espaços geográficos de um país de dimensões continentais aquelas células espaciais dinâmicas nas quais à organização herdada da natureza se sobrepôs ou instalou uma certa organização imposta pelos homens. [...] O espaço geográfico, considerado em sua totalidade, apresenta um caráter de área de acumulação de processos culturais, sobretudo construtivos, ora muito agressivos, ora apenas interferentes, ora dotados de uma espécie de auto-organização que envolve diferentes níveis de acomodação.

Assim, é importante ressaltar, desde já, que o espaço será discutido em termos relacionais, a partir de determinado ponto (empreendimento(s) hidroelétrico(s)) em relação ao rio interferido e a abrangência dessa interferência. Para isso, é necessário levar em consideração a dada noção de espaço segundo os pensadores já citados e a concepção de bacia hidrográfica que segue, em vista de o conjunto desses dois aspectos configurar o sentido de área de influência real de empreendimentos hidroelétricos em epígrafe.

De acordo com Rodrigues e Adami (2011, p. 57, grifo dos autores):

É possível definir bacia hidrográfica como o sistema que compreende um volume de materiais, predominantemente sólidos e líquidos, próximos à 
superfície terrestre, delimitado interna e externamente por todos os processos que, a partir do fornecimento de água pela atmosfera, interferem no fluxo de matéria e de energia de um rio ou de uma rede de canais fluviais. Inclui, portanto, todos os espaços de circulação, armazenamento e saídas de água e do material por ela transportado, que mantêm relações com esses canais.

Denota-se, portanto, que, em termos de aspectos físicos e naturais, a bacia hidrográfica não é apenas a referência do conjunto do rio principal com seus afluentes que se encontram na parte mais superficial da Terra, mas também chega a ultrapassar a superfície terrestre em direção às camadas de seu interior, alcançando o lençol freático. Além disso, abrange as vertentes, nos topos das quais se encontram o que se conhece por divisores de água, pontos limítrofes das bacias hidrográficas, pois segundo Rodrigues e Adami (2011, p. 57):

Os processos de circulação de matéria e de energia que operam em bacias hidrográficas não envolvem apenas canais fluviais e planícies de inundação, mas incluem as vertentes, nas quais os processos internos são de fundamental importância. Um exemplo desse tipo de processo é o escoamento basal que ocorre na primeira zona importante de saturação subsuperficial que, por sua vez, está interligada à planície de inundação ou ao canal fluvial localizado na base dos sistemas de vertentes.

Desse modo, é possível afirmar que a bacia hidrográfica é o sistema formador de um espaço delimitado pelos divisores de água, de acordo com a extensão de cada rio principal em relação a seus afluentes, na superfície terrestre, abrangendo até parte do interior desta.

Já a área de influência real de empreendimentos hidroelétricos em questão, inclui os aspectos da bacia hidrográfica. Além disso, considera a concepção de espaço total definida por Ab’Sáber (2006a).

Tendo em vista que referida área se confirma numa complexidade relacional, sua acepção plena parte da interferência fluvial a partir da instalação e funcionamento de determinados empreendimentos hidroelétricos no sentido da dimensão que as consequências desses podem atingir. Neste caso, se um rio qualquer, com volume de vazão considerável, for interferido devido à instalação e funcionamento de determinado empreendimento hidroelétrico pode sofrer significativa redução do volume de vazão a jusante do seu reservatório de água. Quando há vários empreendimentos instalados e funcionando ao longo 
de cursos fluviais, as consequências ficam acentuadas a partir do último, à jusante do rio, devido à drástica diminuição da vazão em razão do seu controle em todos os reservatórios.

Consequentemente, tanto o meio natural, a hidrografia local ou regional, a biomassa vegetal, entre outros fatores naturais como a fauna, quanto o meio social, o povo ribeirinho, principalmente, e até a população que habita fora da bacia hidrográfica interferida, mas que depende desta para sobreviver, sofrem consequências da referida interferência.

Normalmente, a jusante dos últimos reservatórios, o volume dos rios interferidos passa a ser tão baixo que os afluentes efêmeros, consequentemente, vêm a sofrer impactos ambientais. Ou seja, enquanto o rio principal mantinha a vazão natural, a foz do rio tributário temporário preservava certo volume à sua montante, porém, após a interferência daquele, o trecho que continha água neste rio desaparece na direção do recuo da sua foz. Vindo, com isso, a acarretar consequências também no lençol freático (parte do subsolo que contém água) por causa do seu rebaixamento (diminuição de volume d'água) em função da variação da vazão do rio principal. Igualmente, a biomassa vegetal localizada nas proximidades dos rios de regiões semiáridas, principalmente, será afetada por impactos ambientais devido à diminuição da vazão do rio principal, uma vez que sua exuberância e existência, neste caso, dependem, entre outros fatores, da densidade do lençol freático.

Ainda nesta concepção, o povo ribeirinho sofre consequências drásticas porque o seu meio natural de vida pode estar prestes a ser extinto, pois a fauna aquática (como a população de peixes) tende a diminuir imensuravelmente conforme importantes estudos já realizados. Não só isso, mas, especialmente, seu meio de subsistência como o cultivo de alimentos, dependente do ciclo natural de cheias do rio principal, também corre o risco de ser extinto, assim como já aconteceu com o ciclo do arroz em alguns municípios, comprovadamente, segundo Santos (2010). 
A exemplo deste caso, merece destacar o que ocorreu no Baixo São Francisco, à jusante de Xingó, entre vários municípios sergipanos e alagoanos consumidores de arroz importado de outras regiões do Brasil, por causa da extinção da cultura desse cereal outrora praticada em municípios como Poço Redondo/SE, Porto da Folha/SE, Gararu/SE, Nossa Senhora de Lourdes/SE. A produção do cereal cultivado nesses municípios era tão significativa que chegava a ser exportada, ao contrário do cenário atual, por causa das condições hídricas naturais, assim como foi afirmado anteriormente.

A necessidade do uso da água (recurso natural) transcende as "muralhas" (divisores de água), limites da bacia hidrográfica. Populações que habitam determinadas bacias hidrográficas são abastecidas por água de outras bacias. Isso não tem sido notório só nas regiões semiáridas, mas também em região com importante distribuição de significativos índices pluviométricos durante o ano todo. Aqui não se remete, portanto, a apenas a diminuição da vazão dos rios principais, mas também aos riscos de poluição, visto que se qualquer acidente químico, bioquímico ou biológico ocorrer afetando as águas dos reservatórios dos empreendimentos hidroelétricos, tais populações estão vulneráveis aos eventuais impactos.

Essa é uma das maneiras que o impacto socioambiental é revelado no meio social dentro e ou fora da bacia hidrográfica, onde se originou o impacto ambiental que engendrou aquele impacto. Por exemplo, a poluição da água fluvial pode acarretar danos à saúde das populações que habitam outra bacia e são abastecidas pelo rio interferido.

Assim, o contexto espacial que se revela não se restringe aos limites da bacia hidrográfica, bem como aos divisores de água, nem apenas aos rios interferidos por empreendimentos hidroelétricos, mas tem como delimitação todo e qualquer ponto atingido pelos impactos engendrados a partir da execução e operação de tais empreendimentos. 


\subsection{CRITÉRIOS DEFINIDORES DA ÁREA DE INFLUÊNCIA REAL DE EMPREENDIMENTOS HIDROELÉTRICOS DO PONTO DE VISTA DA GEOGRAFIA A PARTIR DA ANÁLISE DA PAISAGEM}

Inferir sobre os pensadores da geografia cultural foi necessário e, sobretudo, relevante para discernir o que se almeja com esta pesquisa, pois nessa perspectiva foi possível refletir sobre a relação homem - natureza notável na paisagem. Razão pela qual direcionou o presente feito ao estudo da previsão de impactos, dando ênfase ao contexto da área de influência real de empreendimentos hidroelétricos do ponto de vista da Geografia.

Posto isto, sabe-se que critério é "Aquilo que serve de norma para julgar." (ROCHA, 1996, p. 178). O termo julgar, neste caso, refere-se à concepção de formar conceito, pois foi por meio de caracteres criteriosos que a presente pesquisa buscou definir e conceituar a Airehg, conforme segue a abordagem.

Além disso, a reflexão do tema em mote demandou a distinção entre a Airehg e a Área de Influência defendida no EIA/Rima elaborado pelo empreendedor. Assim, é elementar esclarecer que, conforme aqui está sendo discutido, critério significa "Cada um dos elementos que se escolhem para distinguir alguma coisa de outra [...].” (MATTOS, 2005, p. 162).

Partindo do pressuposto de que os critérios adotados para ratificarem as variáveis vêm assegurar o contexto do tema em epígrafe e, por sinal, estão inseridos na paisagem, esta será abordada contemplando algumas características físicas do espaço geográfico e a dimensão que o impacto socioambiental pode alcançar, neste caso. Além disso, o que será abordado faz parte do espaço que, anteriormente, se fez uma reflexão em relação ao seu conceito.

Nessa perspectiva e almejando, em princípio, esclarecer o conceito de paisagem seguem os entendimentos de alguns autores que podem auxiliar, através de tal abordagem, na elucidação da interpretação da área de influência que aqui se buscou fazer. Nesse sentido, as 
características físicas que merecem ser destacadas são aquelas que, principalmente, condicionam a compreensão da delimitação da bacia hidrográfica.

Como bem observou Falcão Sobrinho (2007, p. 51):

Optou-se, neste trabalho, por autores que percebem a paisagem de forma integradora dos aspectos naturais e sociais; dinâmica, enquanto sendo constantemente renovada; herdada, enquanto fruto de um processo histórico e, influenciadora, como agente motivador na tomada de decisões.

É nessa ordem de ideias que os critérios da mensuração da área de influência real de empreendimentos hidroelétricos, do ponto de vista da Geografia, serão discutidos e também serão inferidos na perspectiva da geografia cultural.

Para Bobek e Schmithüsen (1998, p. 83), “A paisagem é um sistema dinâmico com estrutura espacial. A natureza contribui com uma infraestrutura que, apesar do homem, permanece. Os limites naturais são muito estáveis”. Pensar a paisagem nesses termos que não fogem da interpretação que aqui vem sendo realizada significa refletir sobre o que observaram os autores, Bobek e Schmithüsen (1998, p. 83): “Os objetivos fundamentais da análise geográfica da paisagem são descobrir a ordem dentro da multiplicidade, decompô-la e explicar com clareza o emaranhado de relações recíprocas que nela se dá”.

Conforme Sauer (1998, p. 42), "Não podemos formar uma idéia de paisagem a não ser em termos de suas relações associadas ao tempo, bem como suas relações vinculadas ao espaço".

Por um lado, ao tratar da estrutura superficial da paisagem, Ab’Sáber (2005, p. 98) dá referência: “[...] às formas de contato entre os chamados depósitos de cobertura e o subsolo superficial dos terrenos, antevistos em cortes de vertentes ou paredes de erosão”.

Por outro lado, segundo Santos (2007, p. 54), “A paisagem é o resultado de uma acumulação de tempos". 
É importante ressaltar, sobretudo, que "O termo paisagem é usado aqui como o suporte geoecológico e bioecológico modificado por uma infinidade variável de obras e atividades humanas." (AB'SÁBER, 2006a, p. 30, grifo do autor).

Nestes termos gerais, mostra-se também relevante apresentar a distinção com a qual a geografia cultural trata essa importante categoria espacial que se subdivide em paisagem natural e paisagem cultural.

"A divisão de formas em naturais e culturais é a base necessária para determinar a importância da área e o caráter da atividade humana.” (SAUER, 1998, p. 43). Esclarecer isso foi necessário porque, ora os critérios elencados para sustentar o conceito do tema da presente pesquisa dão referência à paisagem natural, ora se referem à paisagem cultural, conforme se apresentam ao longo do texto.

Nesse sentido, é possível dar referência à paisagem natural quando se trata de aspectos geomorfológicos, hidrográficos, entre outras características naturais, originais, isto é, que não sofreram interferência humana.

Esta é a base da premissa valorizada nos aspectos físicos a revelarem a dimensão da área de influência real de empreendimentos hidroelétricos do ponto de vista da Geografia, voltando-se para o caráter descritivo, tendo em vista que, ao estudar a paisagem natural, Sauer (1998) dá importância à descrição.

No caso da paisagem cultural, é fundamental ponderar sobre a opinião dos seguintes pensadores:

Claval (2002, p. 147) afirma que "Entre os pesquisadores que se interessam pelos fatos e cultura, os geógrafos são os únicos a considerar a paisagem como mediadora na transmissão de valores, e a ler nas obras que os homens inscreveram na superfície da Terra um testemunho de suas aspirações e sonhos". 
Ainda conforme Sauer (1998, p. 59), “A paisagem cultural é modelada a partir de uma paisagem natural por um grupo cultural. A cultura é o agente, a área natural é o meio, a paisagem cultural o resultado."

Haja vista à concepção dos autores, a premissa que se confirma na fenomenologia da geografia cultural se fundamenta nesta perspectiva capaz de desvendar o senso da dimensão espacial, que aqui se trata, por meio da relação homem - natureza, isto é, a extensão que o impacto socioambiental alcança.

Partindo da concepção da paisagem natural, cabe frisar que o critério eleito para que se tenha discernimento da área de influência real de empreendimentos hidroelétricos do ponto de vista da Geografia, em relação à geofísica, são as características físicas do espaço geográfico. Estas se destacam, segundo o elemento do espaço geográfico abordado, bem como a bacia hidrográfica, neste caso. Por tratar-se de um rio com curso de grande extensão, e por ultrapassar e formar fronteiras, o São Francisco é um importante exemplo para abordar o assunto proposto, pois há situações em que seus divisores de água são limites territoriais. Noutras situações, o leito fluvial vence a fronteira entre Minas Gerais e Bahia, enquanto que divide outros Estados, assim como Bahia, Pernambuco, Alagoas e Sergipe, respectivamente. Dito isso, já é possível perceber quão complexo é discutir a bacia hidrográfica de tal rio dentro do contexto da presente pesquisa.

Por essa razão, é importante deixar claro que referido critério será abordado sob uma perspectiva descritiva, mas longe de deixar de enfatizar, após a descrição, a discussão do senso espacial, onde se envolvem os seres vivos e o meio ambiente.

Neste caso, os divisores de água são uma das principais referências. Pode-se dizer que referidos divisores são os principais pontos periféricos da área central de convergência. $\mathrm{Ou}$ seja, o curso d'água principal, naturalmente, observado no eixo da bacia hidrográfica, é o coletor de todas a águas oriundas das mais distantes nascentes desde as cabeceiras até os 
sopés das vertentes. Tudo isso está condicionado ao relevo de acordo com a sua elevação e o conjunto das características físicas com capacidade de engendrar força natural para conduzir o fluxo fluvial a um mesmo destino, seja em direção de um lago, mar ou oceano.

Com isso, é possível notar o caráter delimitador desse aspecto físico fundamental para mensurar a área que determinado rio pode influenciar ou sofrer influência geoecologicamente.

Divisor de água é a área de cumeeira em determinada extensão espacial, a partir da qual as águas dirigem-se por força natural para pontos de convergência com destino a determinado sistema hídrico aberto.

Para melhor compreender o contexto do aspecto físico de que se trata, e devido ao fato deste estar relacionado à estrutura e forma do relevo, cabe aqui fazer uma ligeira abordagem, mas fundamental à elucidação a respeito da estrutura geológica da bacia hidrográfica do Rio São Francisco.

Segundo Ross (2005, p. 48):

A plataforma do São Francisco, que se estende desde o norte de Minas Gerais e avança pelo centro da Bahia, é a área cratônica de mais difícil delimitação, pois uma parte encontra-se parcialmente encoberta por sedimentação antiga e as extremidades confundem-se com as áreas dos cinturões orogênicos que a margeiam.

Refletindo sobre essa observação do autor e, principalmente, buscando o entendimento da estrutura física da bacia hidrográfica e o esclarecimento do período geológico de sua existência, bem como dos divisores de água, foi feita revisão da literatura com foco nos estudos defendidos por Ab’Sáber.

Em uma de suas obras, por chamar a refletir sobre o que aqui se busca, apresenta argumentações elementares sobre o assunto, motivo pelo qual passou a ser consultada. Conforme Ab'Saber observa (1956, p. 228, grifo do autor), "Nossas bacias sedimentares páleo e mesozoicas são vastas depressões de espessura mediana, aninhadas no dorso dos escudos arqueoproterozoicos, tendo-se comportado como áreas de subsidência extremamente moderada durante o longo período deposicional que as afetou". 
A esse respeito, é importante considerar que, de acordo com Ab’Sáber (1956), nas bordas da Bacia São Francisco existem depósitos do Paleozoico inferior e esses vestígios se apresentam em forma de dobras suaves.

Assim, levando em conta a ideia do autor, por saber que a era Mesozoica se estendeu entre 220.000.000 (duzentos e vinte milhões) e 135.000.000 (cento e trinta e cinco milhões) de anos e a Paleozoica inferior pode ser mensurada entre 400.000.000 (quatrocentos milhões) e 270.000.000 (duzentos e setenta milhões) de anos, os divisores de água da Bacia Sãofranciscana podem datar dessas duas eras. É relevante frisar que, por causa dessa estrutura e forma do relevo, essa bacia hidrográfica é também chamada de Depressão Sãofranciscana.

Desses pontos limítrofes, partem os afluentes do rio principal, os quais, para este, têm significação relevante por serem parte integrante do sistema hidrográfico, de maneira que o segundo é dependente dos primeiros. Uma das principais características de um rio ser afluente é a sua função ao contribuir, isto é, destinar a água que corre em seu leito ao outro rio.

Já os subafluentes são rios de menor importância, mas com valor considerável, devido à sua integração ao sistema, pois suas águas colaboram com o volume dos afluentes do ponto central da área de convergência.

O principal curso d'água atrelado a toda essa inter-relação ratifica a integração do sistema superficial e evidencia que todas as partes descritas formam o todo desta análise espacial. O rio principal caracteriza-se por possuir a maior extensão de correnteza desde a nascente mais distante, ligada diretamente ao mesmo rio, até desaguar na sua foz.

É nesta área de convergência que se concentram os aspectos geoecológicos e bióticos, mas não é de se desprezar que referidos aspectos, assim como outros, também são notórios nos pontos acima descritos, visto que todos integram o mesmo sistema.

Partindo dessa análise geoecológica, notou-se o seguinte: ao longo do tempo em que a bacia hidrográfica do Rio São Francisco apresentou as características do espaço físico 
preservadas, estas testemunharam que as cachoeiras não tinham a função impeditiva em relação ao fluxo da biota fluvial. Naquele tempo, ainda antes das execuções dos empreendimentos hidroelétricos, era comum pescar peixes da mesma espécie ao longo do rio, do baixo ao médio curso, assim como a piranha e o piau. Referidas espécies eram abundantes e certamente essa ocorrência se dava em função das cheias que causavam a turbidez da água, o que também colaborava com importante incremento da população de peixe. Nessas duas partes do curso fluvial, onde era possível notar o maior volume de água, a vazão já alcançou a casa dos $13.000 \mathrm{~m}^{3} / \mathrm{s}$.

Além disso, pode-se dizer que a inter-relação do sistema aquático entre os cardumes de peixe ocorria no ciclo de cheias naturais quando também acontecia a piracema. Nesta época, as corredeiras e cachoeiras eram vencidas pelos cardumes que se dirigiam em direção da nascente, fenômeno natural que hoje não é mais possível devido à ação humana no meio ambiente conforme está sendo abordada no presente estudo.

No que concerne à fauna aquática, certamente, os peixes não ultrapassam as "fronteiras" da bacia hidrográfica. Em contrapartida, a fauna terrestre, assim como a onça, o veado catingueiro, entre outros, são espécies capazes de migrar entre uma bacia hidrográfica e outra, dependendo da localização de seus habitats. Por exemplo: em períodos sazonais distintos, enquanto durou o ciclo de cheias naturais no São Francisco, era comum observar a segunda espécie nas vertentes da Serra Negra, divisa entre Bahia e Sergipe, na região do divisor de águas das bacias hidrográficas dos rios São Francisco e Sergipe.

Quanto à avifauna, as aves merecem destaque, pois várias espécies migratórias como a águia-pescadora, o marisco pintado, entre outras, transcendem os divisores de água da Bacia São Francisco, observadas próximo à foz. Nesse sentido, segundo Valente (2011, p. 164), “As aves migratórias que frequentam as imediações da foz do Rio São Francisco utilizam a área 
para alimentação e descanso quando de sua passagem pelo litoral brasileiro, durante a sua migração trans-equatorial".

De acordo com as condições fitogeográficas, além das formações vegetais, seu porte, e das formas do relevo, considerando a dimensão da Bacia São Francisco, o clima é outro fator natural importante que transcende as "muralhas" da bacia hidrográfica. Certo de que há vínculo entre o clima e a vegetação, as características de formação desta em função daquele podem se estender em determinada extensão de duas bacias hidrográficas, inclusive, passando pelo seu divisor de águas. Neste caso, isso ainda é possível ser observado na Serra da Canastra, ao passo que na Serra das Vertentes (ambas as serras no alto curso) essas mesmas características de outrora já não podem ser conferidas em toda a sua extensão hoje em dia devido à ação antrópica no seu meio ambiente.

Ratificam-se as assertivas acima, conforme bem observaram Conti e Furlan (2005, p. 73): “A biosfera possui uma infinidade de habitats. Dentro deles os seres vivos estão interligados numa rede de relações de dependência. Na floresta tropical, por exemplo, essas formas de cooperação criam microcondições climáticas, agora na escala da comunidade”.

Nessa concepção, pôde-se notar que, em termos geoecológicos, ainda que se considerem os aspectos físicos do espaço geográfico como os divisores de água sendo principais delimitadores da bacia hidrográfica, estes são ultrapassados pelos seres vivos no seu processo de inter-relação em comunidade. Ou seja, referidos divisores só mantêm seu aspecto delimitador em relação às águas superficiais e à forma do relevo, representando as características da paisagem na dimensão da bacia hidrográfica. Isso se justifica também conforme a estrutura do relevo, haja vista às possibilidades de qualquer percentual das águas de uma bacia hidrográfica passar para a outra através de alguma falha em estrutura rochosa no sopé da vertente ou em outro ponto, por exemplo, conforme bem observou Aldo da Cunha Rebouças (1999), a respeito de seu estudo sobre as águas subterrâneas. 
Até este ponto da abordagem, nota-se que, apesar dos divisores de água se mostrarem "estáticos", a reflexão do ponto de vista da paisagem natural vem sustentar a ideia de que a área de influência real de empreendimentos hidroelétricos, do ponto de vista da Geografia, não se limita a essa forma do relevo. Contudo, os divisores são fundamentais pontos de partida do contexto empírico e teórico que se engendra a partir do espaço físico.

Considerando que referida área de influência, neste caso, se vale da conjugação de outros aspectos físicos do espaço geográfico, as correlações existentes entre estes no ecossistema ratificam as possibilidades de tais aspectos colaborarem com o discernimento daquela área. Ao que se considera por ecossistema, é levado em conta a natureza e, na sua dependência, as possibilidades da relação entre os seres vivos e o meio ambiente onde suas comunidades habitam formando, assim, um conjunto, o dito ecossistema. O que chama a atenção aqui não é o conceito ecossistêmico, mas a dimensão que pode ser alcançada através da interação que há entre tais comunidades e os fatores do meio ambiente que também são parte do referido conceito.

A correlação entre os seres vivos e o meio ambiente, existente no espaço hidrográfico, se revela como um dos principais fatores capazes de transcender os divisores de água.

Nesse sentido, reforça as assertivas acima, o que observou Claval (2007, p. 219): “A extensão pela qual se interessam os geógrafos não é a superfície abstrata do mapa onde reportam os resultados de suas pesquisas [...]". De acordo com a concepção do próprio autor, são os meios de vida, através dos quais os homens estabelecem as necessárias relações ecológicas, que concernem aos geógrafos.

Assegurando-se que a problemática do presente estudo gira em torno de uma importante discussão espacial, envolvendo a ação antrópica, a execução e operação de empreendimentos hidroelétricos se apresentam, nesse sentido, como um dos pontos cruciais. Desse modo, é 
preciso entender que "As ações do homem se expressam por si mesmas na paisagem cultural." (SAUER, 1998, p. 43).

Isso se deve ao fato de que os impactos socioambientais adotados como critério, neste caso, têm origem na execução e operação de empreendimentos hidroelétricos, o que exige reflexão a esse respeito. Assim, de acordo com Ab’Sáber (1991, p. 43):

No caso das hidrelétricas, o problema reside nisso. Trata-se de compreender os tipos de espaços que os homens fizeram ao longo do tempo sob as heranças da natureza modificadas através de ciclos econômicos nem sempre contínuos, mas sempre interferentes em relação às heranças ecológicas e bióticas.

Por essa razão, inicialmente foram abordados os aspectos físicos do espaço geográfico por serem fundamentais às possibilidades de correlação entre os seres vivos e o meio ambiente; além disso, seria inviável discutir referidos impactos sem antes ter feita tal abordagem. Ou seja, é preciso evidenciar que há um espaço sobre o qual o homem está inserido e por causa da ação dele se engendraram resultados ao longo do tempo, sejam benéficos ou prejudiciais ao seu desenvolvimento.

Da análise da pesquisa, ratificam-se as assertivas acima, de acordo com Corrêa e Rosendahl (1998, p. 9): “A paisagem cultural ou geográfica resulta da ação, ao longo do tempo da cultura, sobre a paisagem natural".

É nessa perspectiva que vai se buscar interpretar o "espaço total" no intuito de conceituar a área de influência real de empreendimentos hidroelétricos, do ponto de vista da Geografia, dentro da abordagem da paisagem.

Partindo dessa concepção, faz-se necessário tratar do critério que se revela na paisagem cultural e serve de base para esse conceito.

Pode-se dizer que, ainda no período entre os séculos XVI e XVIII, o Rio dos Currais (Rio São Francisco, outrora, assim, conhecido) já se apresentava com configuração de paisagem cultural em alguns pontos, principalmente no seu baixo curso, de onde partiu sua exploração após os portugueses descobrirem sua foz em 1501. O fato é que a partir daquele 
período suas margens e de alguns de seus afluentes dessa região passaram a ser ocupadas pelo homem criador de gado, isto é, o colonizador.

Com isso, nota-se que a configuração da paisagem cultural da Bacia São Francisco não foi exclusividade do século XX, quando o rio foi marcado com as execuções dos vários empreendimentos mencionados anteriormente. Neste caso, as interferências que o espaço fluvial sofreu, em termos de impacto ambiental (consequência que atinge o meio ambiente por causa da ação humana), foram muito mais expressivas e, por isso, a análise que se faz do critério aqui eleito parte deste período, meados do século XX.

O estudo realizado sobre os impactos socioambientais desencadeados nas margens do Rio São Francisco, conforme observou Santos (2008), mostra dois momentos de grande importância para a presente pesquisa. No primeiro, o autor comprovou a ocorrência de impacto ambiental nas margens do rio atribuindo-o à diminuição de vazão a partir da execução e operação do Empreendimento Hidroelétrico Xingó. Em função disso, o ciclo natural de cheias foi extinto, ratificando o referido impacto estampado na paisagem fluvial. No segundo momento, ele contextualizou que o povo do lugar passou a sofrer consequências drásticas tanto em relação ao seu modo de vida, quanto aos seus costumes, e que tudo isso resultou do impacto ambiental causado a partir da hidrelétrica. Esclareceu também que este impacto engendrou outras consequências denominadas de impacto socioambiental. Ou seja, o impacto socioambiental é a consequência que a sociedade sofre por causa do impacto ambiental manifestado na natureza.

Quando se trata desse tipo de transformação envolvendo a natureza de um rio, principalmente do porte como o São Francisco ou o Nilo, não há dúvidas de que as consequências capazes de atingir a sociedade não se restringem à bacia hidrográfica. Essa premissa envolve uma variável fundamental a ser destacada aqui, isto é, o uso da água. 
O mapa (fig. 03) a seguir traz uma representação desse contexto, destacando-se a relação sociedade - natureza, por exemplo, através do o uso da água.

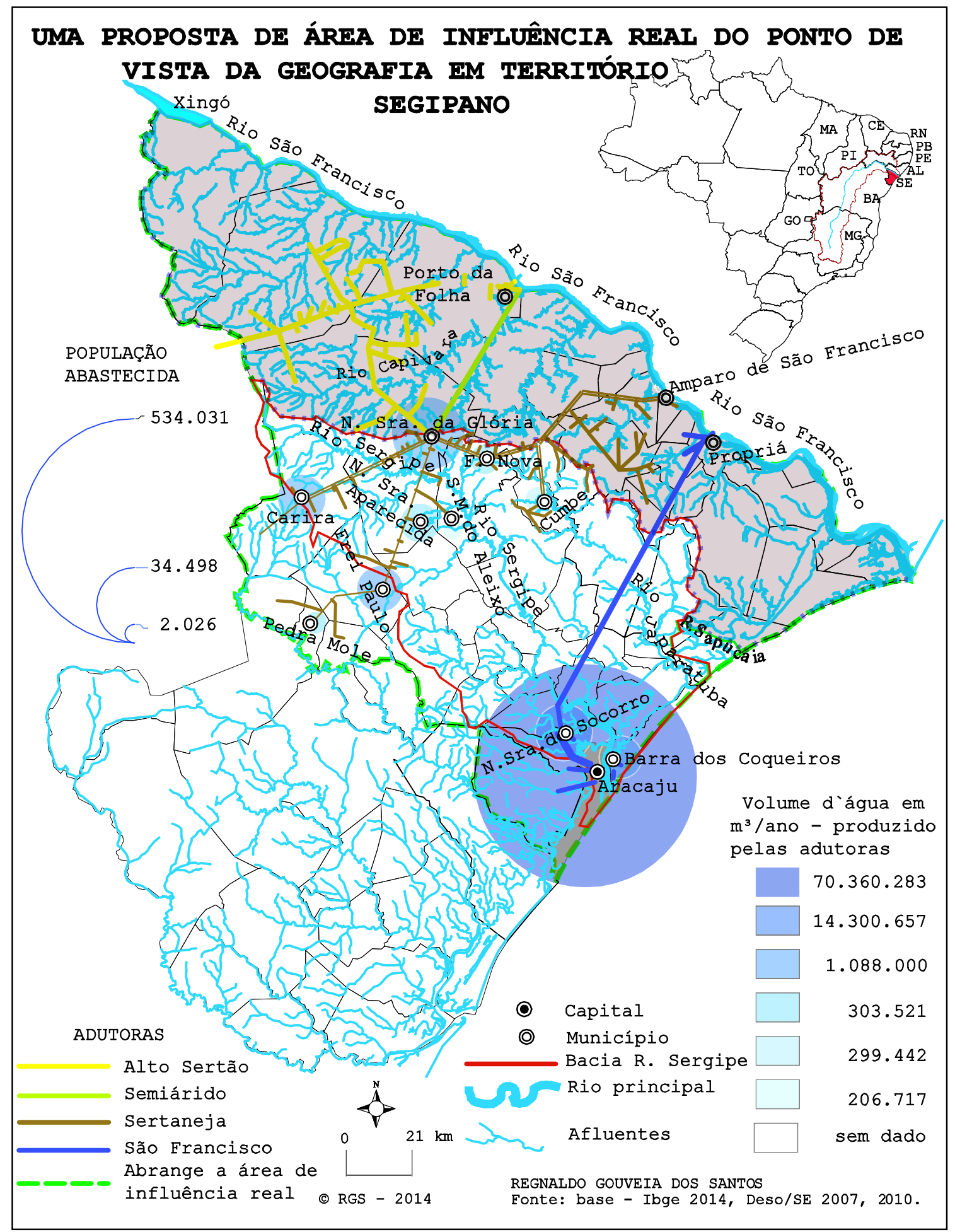

Figura 03. Mapa representando a área de influência real de empreendimentos hidroelétricos, do ponto de vista da Geografia, em território sergipano. 
É importante ressaltar que a abrangência da área de influência real representada no mapa (fig. 03) acima tem como limite, exclusivamente, os municípios que se beneficiam do uso da água do Rio São Francisco. Desse modo, a linha verde e tracejada não é um limite exato, pois há alguns territórios municipais dentro de referida delimitação que não são abastecidos pelo rio, mas a mesma linha dá noção da dimensão espacial da influência das adutoras que fazem uma conexão do "Velho Chico" com os municípios beneficiados por sua natureza (a água). Como se pode observar, referida linha se situa apenas no Estado de Sergipe por este ter fornecido os dados que possibilitam as informações notáveis e transmitidas ao observador através da análise do mapa.

Entre outras maneiras, conforme a abordagem anterior referente à possibilidade da correlação existente entre os seres vivos e o meio ambiente, também é possível mensurar a dimensão espacial que o impacto socioambiental é capaz de alcançar por meio da variável, uso da água (representada no mapa (fig. 03)). Neste caso, é fundamental reconhecer o senso de previsão de impactos antes de realizar o desejável empreendimento por que, em função da sua execução e operação, tais alterações ambientais estão predestinadas a confirmar-se.

Para definir o termo previsão de impactos é necessário levar em conta o "espaço total" conforme está sendo abordado. Nestes termos, significa, entre outras considerações, ponderar sobre a organização espacial em tempo presente e futuro a curto, médio e longo prazo, antes mesmo dos danos ambientais ou socioambientais se revelarem. Por isso, de acordo com Ab’Sáber (2006a, p. 30, grifo do autor): "Por numerosas razões, o conceito de espaço total passa a ser o centro das considerações para uma correta previsão de impactos, em face de qualquer tipo de projeto a ser introduzido em qualquer área de um determinado território”.

Conforme anteriormente já mencionado, o presente estudo não trata de avaliar o impacto ambiental, mas busca mostrar uma representação da dimensão que o impacto socioambiental pode alcançar, no caso estudado, através da análise da paisagem. Investiga, 
por meio da citada variável, o uso da água, como tal dimensão se revela por meio das possibilidades de relação que há entre a sociedade e a natureza.

Neste caso, por exemplo, a população que habita o município Nossa Senhora do Socorro/SE, localizada fora da bacia hidrográfica do Rio São Francisco e que recorre à fonte de abastecimento público desse rio, está vulnerável às consequências dos impactos ambientais que o ecossistema fluvial sofrer. Nesse sentido, valendo-se do uso da água, confirma-se tal vulnerabilidade ${ }^{1}$. Esse é um dos meios que podem mensurar a dimensão que o impacto socioambiental pode alcançar e, para tal, é sempre necessário haver, pelo menos, a relação entre o ser humano e o meio ambiente interferido, direta ou indiretamente, dentro ou fora da bacia hidrográfica na qual foi engendrado o impacto ambiental.

Da análise do mapa (fig. 03) anterior, nota-se que há outros municípios em mesma situação geográfica, isto é, situados fora da Bacia São Francisco, mas também abastecidos pelo mesmo rio. É importante esclarecer que tais municípios têm outras origens de captação de água, bem como poços e outros rios. Contudo, um volume de água significativo é oriundo do Rio São Francisco ao ponto de abastecer importantes áreas urbanas de vários municípios, e um dos exemplos é o caso de Nossa Senhora do Socorro/SE, já mencionado, com destaque para o Conjunto João Alves, vizinho à capital sergipana. Isso comprova o vínculo que há entre a população desses municípios e o rio, por se beneficiar com suas águas, apesar de não habitar a referida bacia hidrográfica.

No intuito de melhor esclarecer como se dão as possibilidades da relação do homem com a natureza através do uso da água, vale remeter-se à geo-história, organizando alguns fatos importantes para o contexto do fenômeno aqui estudado.

\footnotetext{
${ }^{1}$ SIMÕES, Edlamar Nascimento Oliveira. Entrevista concedida a Regnaldo Gouveia dos Santos. Nossa Senhora do Socorro/SE, 04 de janeiro de 2014. Declarou: “A relação é muito grande, né? Sem o Rio São Francisco, a gente não vive, né? Por isso que a gente tem uma relação assim, com ele e não pode viver sem ele, a gente depende do Rio São Francisco pra tudo".
} 
O Empreendimento Hidroelétrico Paulo Afonso surgiu em meados do século XX e, ao final de sua conclusão, foi denominado complexo hidroelétrico, por compor quatro usinas hidrelétricas instaladas umas próximas das outras, o que interferiu no leito do rio.

Ao longo da década de 1950, quando se consolidou tal empreendimento, até final da década de 1990, período de conclusão da obra e início das atividades da Usina Hidrelétrica Xingó, pôde-se analisar e compreender a dimensão que o impacto socioambiental pode alcançar.

No caso do Complexo Paulo Afonso (PA) I, II, III e IV, o regime do rio não sofreu interferência muito expressiva, tanto que na década de 1970 ainda foi registrada a vazão de mais de $12.000 \mathrm{~m} 3 / \mathrm{s}$., segundo dados apresentados por Santos (2010). Isso foi observado no Reservatório Sobradinho, situado a montante, em 1979, mostrando também que a existência desse empreendimento não extinguiu o ciclo de cheias naturais. A essa altura já existia a Barragem Três Marias, empreendida logo após o período do Complexo Paulo Afonso, mas vários outros empreendimentos foram instalados ao longo do tempo e do espaço fluvial, assim como Luiz Gonzaga (Antiga Itaparica), Moxotó e Xingó. A partir deste, extinguiu-se o ciclo de cheias naturais, fator que acarretou impactos imensuráveis.

É importante frisar que, ao se tratar da fauna aquática, à medida que o tempo passou, conforme a ação humana foi se confirmando, de forma interferente sobre o rio, a ictiofauna foi sofrendo mudanças. Os barramentos através do leito do rio que impedem a piracema, conforme testemunho dos habitantes locais ${ }^{2}$, estão entre os principais fatores que mais pesaram a esse respeito. No período em que se antecedeu à execução dos empreendimentos

\footnotetext{
${ }^{2}$ SILVA, Geraldo Soares. Entrevista concedida a Regnaldo Gouveia dos Santos. Brejo Grande /SE, 03 de janeiro de 2014. Informou que quando "[...] tinha época de influência de enchente, nós pegava aqui, xira, camarões, tudo. Tudo era com grande a influência [cheia natural do São Francisco], né? Era... boas influências sim”.
} 
hidroelétricos ao longo do Rio São Francisco, este representava muita importância para a vida do ribeirinho ${ }^{3}$.

Referentemente a tais fatores, outro agravante é a qualidade da água devido ao seu tempo de permanência nos reservatórios. Essa é mais uma variável abordada e parte integrante do impacto socioambiental, isto é, a dimensão espacial que esse impacto pode alcançar. A partir da instalação e operação do Complexo PA I, II, III e IV, primeiro empreendimento instalado, observou-se com o passar dos anos que foram formados mais reservatórios e que todos se somam como causa da diminuição da qualidade das águas do Rio São Francisco. Suas condições pioram de acordo com a intensidade do controle de vazão nos reservatórios segundo os interesses da geração de energia ou de destinação de seu uso.

Em outras palavras, a água parada em função das barragens, somada à intensidade solar sobre o espelho d'água, tornam-se causa da proliferação de matéria orgânica. Esta, por sua vez, aumenta desordenadamente a matéria vegetal que, ao se decompor, engendra a diminuição do oxigênio, o que afeta não só a vida animal, mas também a do homem. Durante a pesquisa, notou-se que a jusante de todas as barragens, no baixo curso, quando as pessoas estão se banhando no rio, geralmente são laçadas por um tipo de alga passando na frágil correnteza do raso e largo curso.

Entretanto, não é só isso que afeta a qualidade desse líquido que é vital para os seres vivos. A exploração capitalista do campo, através da agroindústria, também tem sua parcela de participação quanto à degradação ambiental, visto que parte de seus insumos e agrotóxicos escoam para o rio. Quando não o alcançam diretamente, são absorvidos pelo solo, e mais cedo ou mais tarde o atingem, pois o ponto de convergência é o rio principal da bacia hidrográfica.

\footnotetext{
${ }^{3}$ SILVA, Geraldo Soares. Entrevista concedida a Regnaldo Gouveia dos Santos. Brejo Grande /SE, 03 de janeiro de 2014. Afirmou: "[...] tinha mais enchente, tinha mais a fartura de peixes, hoje o rio não tem essa influência mais, por causa dessas barragens lá em cima, parou a água, tá perto, baixa, né? Hoje nós não tem a influência que tinha antigamente, né"?
} 
Ou seja, ao chover, as águas tomam a direção de seu curso subterrâneo ou pela superfície, após lavarem as plantações agrícolas e seus solos contaminados.

Igualmente pode-se dizer da destinação de efluentes industriais e domésticos das grandes cidades desta bacia hidrográfica e, sobretudo as de médio porte, ribeirinhas, como Juazeiro/BA - Petrolina/PE, entre outras.

O maior agravante é que tudo isso, ao permanecer no reservatório, conforme acima mencionado, tende a se proliferar por causa do processo de eutrofização, o que pode afetar a qualidade da água devido ao tempo que passa estagnada e, com isso, expor o meio ambiente e a população a uma situação crítica. Referido processo acontece devido à concentração de substâncias químicas como nitrato e fosfato, entre outras, com potencial de provocarem um aumento de matéria orgânica em áreas com água parada, de maneira que polui o meio ambiente. Certamente, entre todas as partes da bacia hidrográfica, a mais afetada pelos impactos ambientais é o baixo curso e, por consequência destes, o ribeirinho dessa região é a principal vítima de tais impactos.

Da análise da pesquisa, foi possível observar que as condições do rio próximo à foz estão tão precárias que o povo compra água mineral para beber ${ }^{4}$.

Denota-se que esses impactos se situam dentro da bacia hidrográfica, porém, quando se trata do uso da água, podem se alastrar além desse espaço, transcendendo os divisores de água e alcançando habitantes de outras bacias hidrográficas, também beneficiados pela água do São Francisco.

Tendo em vista a diminuição do volume do rio, a situação dos beneficiados fora de sua bacia pode ficar ainda mais vulnerável aos impactos (quando quiçá houver racionamento de água, por exemplo) quando os canais da transposição passarem a operar. Além de tudo, todos

\footnotetext{
${ }^{4}$ SÁ, José. Entrevista concedida a Regnaldo Gouveia dos Santos. Piaçabuçu/AL, 03 de janeiro de 2014. Informou que "A água hoje não vale nada. A gente sente, todo mundo sente que o povo... tanto que nós não... aqui tem a água... a água do... da Casal [Companhia de Saneamento Básico de Alagoas], mas nós compra água mineral que a Casal é tirada água do rio. Porque nós num... num gosta mais da água. É porque ela vem muito poluída".
} 
os lugares abastecidos por tais canais estarão sujeitos aos mesmos impactos, por se situarem a jusante do reservatório de Sobradinho.

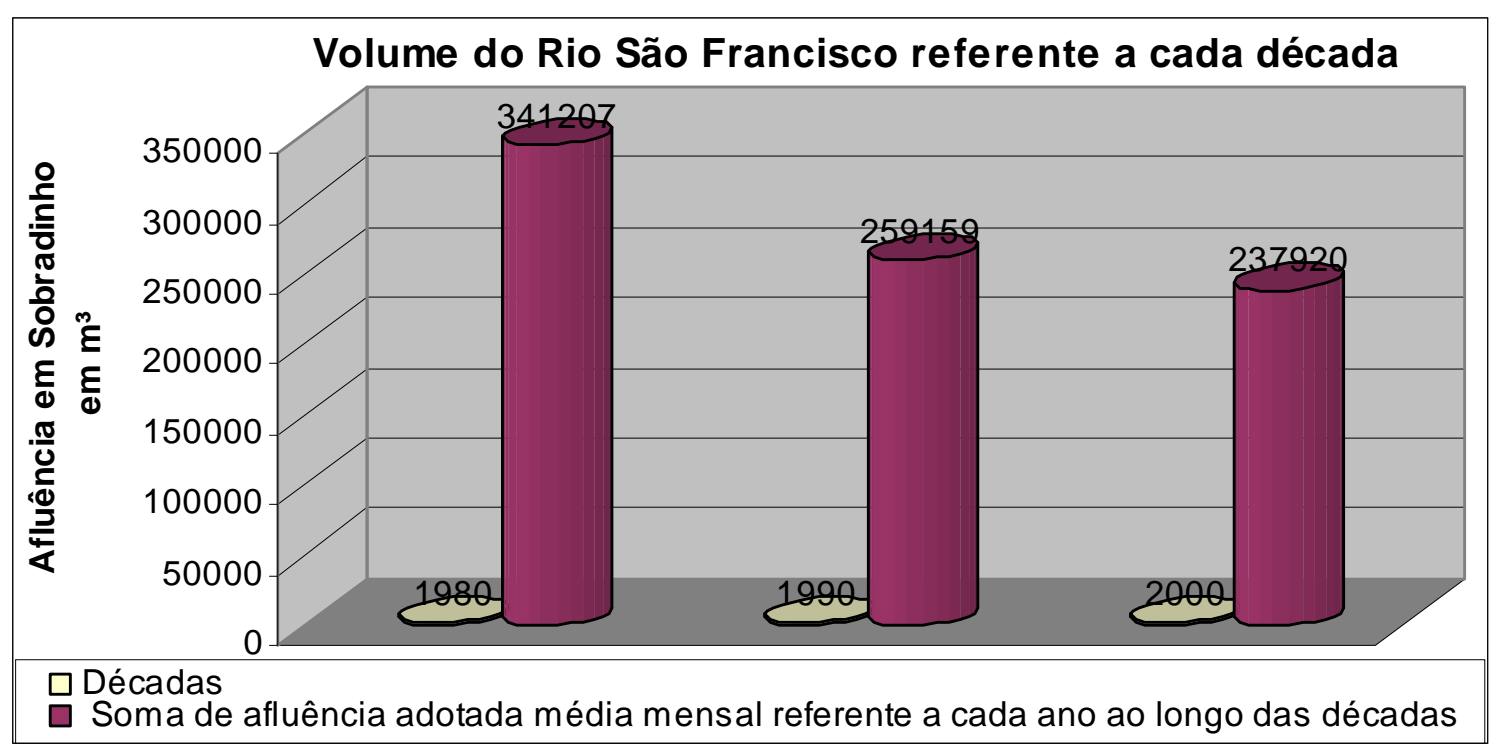

Figura 04. Representação gráfica da redução do volume de água do São Francisco, nas últimas décadas.

Ao observar o gráfico acima (fig. 04), comprova-se que a cada década o volume do Rio São Francisco vem diminuindo em função do seu decréscimo, conforme registros de afluência, isto é, entrada de água nesse reservatório.

Ao longo do tempo e da interferência humana sobre o espaço fluvial, sobretudo a partir da implementação desses grandes empreendimentos hidroelétricos, foi possível observar que seu ecossistema passou a se modificar por causa da desconfiguração natural do rio. Esse foi um dos fatores, senão o mais importante, que acarretou a alteração da qualidade da água conforme reclamações dos ribeirinhos no Baixo São Francisco. É correto afirmar que, se não houvesse tais interferências, a correnteza e o grande volume natural do rio teriam condições, em termos, de manter a qualidade da água, e a grande maioria desses impactos não se confirmariam. Neste caso, vê-se que é necessário manter as nascentes em seus aspectos naturais, pois é preciso não esquecer que a água pluvial precipitada dentro da bacia hidrográfica não tem outro caminho a percorrer, a não ser escoar para o rio principal ou 
evaporar uma parcela, naturalmente. Por disso, é preciso sempre tratar a água utilizada quando descartada ou destinada a qualquer rio, lago ou reservatório.

Se os devidos cuidados fossem tomados de fato, a grande maioria dos impactos ambientais não se confirmaria, mas como ações efetivas não são implementadas nesse sentido há alguns impactos que nem mesmo a vazão natural do rio seria capaz de evitar, a curto prazo, conforme a abordagem que se segue, ainda que o volume do rio voltasse ao do ciclo natural de cheias.

Fato que pouco se cogita ou quase nunca se tem ouvido falar, com relação a toda essa abordagem realizada é que qualquer alteração bioquímica (conforme seu esclarecimento a seguir), observada no ecossistema fluvial, originária de efluentes urbanos industriais ou domésticos, ou da agroindústria, além de alterar a qualidade da água, afeta a população da bacia hidrográfica e de toda a região que se beneficia do uso da água. Neste caso, consideram-se como alteração bioquímica as reações que os organismos vivos do rio podem sofrer em função de sua exposição a grande variedade de produtos químicos que atingem as águas, mormente nos pontos de estagnação como os reservatórios.

$\mathrm{Da}$ análise da pesquisa, denota-se que esse impacto ambiental engendra o impacto socioambiental ao atingir a população vinculada ao rio, de qualquer maneira, ainda que se encontre fora da bacia hidrográfica, a exemplo do que ocorre com o conjunto de pessoas abastecidas pelo Rio São Francisco.

Nesse sentido, estudos apontam um tipo de poluição que afeta as águas dos rios, por exemplo, como bem observou Christante (2010, p. 19):

As substâncias hidrossolúveis contaminam o esgoto e se disseminam pelo planeta através dos rios e oceanos. Nessa categoria encontram-se os estrógenos naturais excretados por mulheres e qualquer outra fêmea de mamífero. Como sua concentração na urina é muito baixa (da ordem de nanogramas por litro), eles passavam despercebidos pela química analítica, cujos métodos apropriados para detectar quantidade tão ínfima (mas suficiente para deflagrar efeito biológico) só surgiram na última década. Até hoje, porém, nenhum método de tratamento de esgoto ou da água é capaz de removê-los. 
Assim, os peixes são atingidos por esse tipo de poluição, pois o habitat fluvial como se percebe, está sofrendo agressão desse gênero.

Segundo a autora, esse tipo de contaminação causa uma confusão na ação do hormônio sexual feminino, o dito estrógeno, ou seja, aquele é conhecido como interferente endócrino (referente às glândulas). Do ponto de vista biológico, significa dizer que, no momento certo do estímulo hormonal, tal contaminação causa alteração nesse processo quando passa a ocorrer a definição original das características e comportamentos relativos ao sexo, que se apresentarão por toda a vida. Segundo Christante (2010), esse é o período crítico de exposição nessa fase de desenvolvimento.

Entre outras substâncias que atuam como interferentes endócrinos há os sintéticos, que são compostos hormonais dos anticoncepcionais. Após o uso dos medicamentos, tais substâncias são excretadas pelas pessoas e se destinam aos esgotos, que na maioria das vezes alcançam os rios.

Como se não bastassem, há preocupações que pairam dentro das residências, visto que até as crianças estão expostas aos riscos da poluição hormonal devido aos ftalatos e bisfenol A, que são compostos químicos existentes em brinquedos e plásticos para ganhar maior flexibilidade, além da composição de garrafas pet, dentre outras embalagens diversas que geralmente, após o seu uso, têm como destino os lixões. Estes, muitas vezes irregulares e localizados em pontos totalmente inadequados, em divisores de água, e sem devido tratamento, contribuem com a ocorrência de referida poluição, de modo que, com as chuvas, uma parte das substâncias segue de imediato para o lençol freático e a outra para os rios.

Às margens do Rio São Francisco existem diversos municípios que não possuem aterro sanitário, propiciando, portanto, tais condições. Ainda que todos tratassem a água usada quando destinada ao rio, nem assim tal poluição seria evitada a partir do alto curso fluvial. 
Ratificam-se as assertivas acima considerando que as citadas substâncias, de acordo com Christante (2010, p. 20): "Com o tempo, elas se desprendem dos materiais e contaminam o ambiente doméstico, até parar no esgoto e nos cursos d'água".

Nesta concepção, observou-se que os rios mais vulneráveis à poluição hormonal são os que têm suas margens ocupadas, especificamente por cidades modernas industrializadas e de grande porte, e também por agroindústrias ou agricultura capitalizada. Neste caso, o Rio São Francisco merece destaque por banhar áreas urbanas de porte considerável como Três Marias/MG, Juazeiro/BA - Petrolina/PE, Petrolândia/PE, Paulo Afonso/BA, além de receber as águas que banham a metrópole mineira.

Desse modo, é nas áreas alagadas dos grandes empreendimentos hidroelétricos que referidas substâncias se proliferam devido à diminuição da correnteza do curso d'água. Nesse sentido, o regime do rio tinha um significado enquanto corria naturalmente, mas após sofrer as interferências ao longo de seu curso, passou a apresentar outro significado, inclusive a lentidão da correnteza como ocorre dentro das áreas alagadas. Noutros termos, o regime do rio era natural e hoje em dia denota-se como artificial, isto é, controlado pelo homem através de sua arte de empreender projetos hidroelétricos.

Ou seja, a estrutura das barragens ou reservatórios desses tipos de empreendimentos vem colaborar com a acumulação de objetos que contêm as substâncias danosas à saúde humana, e que comprometem o sucesso reprodutivo de várias espécies animais. Desse modo, ao longo do tempo, devido ao fato dessas substâncias se desprenderem dos materiais que as compõem, passam a poluir as águas dos reservatórios ou barragens, afetando entre outras espécies, as aquáticas, e a saúde das pessoas sujeitas a essa água, independentemente de onde elas estejam morando, dentro ou fora da bacia hidrográfica afetada, conforme já afirmado.

Além dos objetos compostos por essas substâncias alcançarem os reservatórios dos empreendimentos hidroelétricos e permanecerem nestes por tempo indeterminado em função 
da diminuição da correnteza, há os agrotóxicos como o fibronil, entre outros ainda em uso, que são fontes desse tipo de poluição. Estes, por serem pouco solúveis na água, após alcançarem os rios, se alocam em sedimentos aquáticos, atingindo a cadeia alimentar da fauna aquática e os pontos mais vulneráveis se apresentam onde a correnteza fluvial estiver mais frágil.

Assim, entende-se que toda população humana ou animal, tendo qualquer ligação com o rio interferido desse modo, sobretudo pela ingestão da água, está vulnerável ao impacto ambiental. À medida que este passa a engendrar consequências às pessoas, é denominado de impacto socioambiental, conforme já foi dito.

Agora, cabe definir o tema em epígrafe, a saber: a área de influência real de empreendimentos hidroelétricos é toda a abrangência de qualquer bacia hidrográfica a partir do seu ponto interferido por tais empreendimentos até o alcance dos impactos, quer seja no meio natural ou social, quer seja dentro ou fora de referida bacia hidrográfica. Isto é, essa área não se restringe aos limites da bacia hidrográfica, mas tem de levar em conta todo e qualquer espaço que, direta ou indiretamente, sofreu alguma consequência por causa de sua relação com o rio interferido, neste caso. Para compreender seus pontos limítrofes e ratificá-los é necessário analisar cada caso, de maneira acurada, com todos os cuidados que tem um bom geógrafo ao estudar todo e qualquer espaço geográfico. Tal espaço deve ser considerado como um todo, de forma que cada uma de suas partes seja criteriosamente observada e reconhecida em toda sua composição física, natural e social para que não se venha incorrer em qualquer erro de análise a respeito do caso estudado. Dessa forma, é possível afirmar que esse seja um dos modos que dá a condição de evitar alguns desacertos acarretados sobre o meio ambiente por causa da ação humana. Ou seja, talvez seja mais complexo (portanto, mais trabalhoso) romper os entraves de determinado problema como um todo do que a partir de cada parte que lhe compõe. 
Ratificam-se as assertivas acima segundo o que observou Ab'Sáber (2006a, p. 27):

A ciência básica é ética por princípio, enquanto as aplicações práticas das ciências podem envolver tal gama de distorções e subjetividades que chegam a engendrar situações anômalas, antiéticas e até criminosas. Prever impactos, nessa ordem de ideias, significa aplicar uma vacina contra as resultantes de um uso incorreto de tecnologias ou de falsas argumentações.

É nessa concepção que várias entrevistas, realizadas com pessoas afetadas pelo problema em questão, revelam os falsos argumentos que podem até ser entendidos como verdadeiros fetiches do desenvolvimento. Em outros termos, os idealizadores dos empreendimentos em questão passam a ideia, para o povo local ou regional da instalação empreendedora, de que ali receberá importantes investimentos, de maneira que ocorrerá um desenvolvimento vultoso e de forma sustentável, respeitando o meio ambiente. Nesse contexto, quando representantes dos empreendedores se referem à falta de infraestrutura no local ou região de instalação do empreendimento, bem como a ausência de saneamento básico, de abastecimento público, chegam a afirmar o que confere a entrevista ${ }^{5}$.

$\mathrm{Na}$ realidade, isso se torna, muitas vezes, uma verdadeira ilusão na cabeça das pessoas mal esclarecidas e ingênuas, visto que tal assunto tem sido pouco discutido por todos formadores do espaço atingido pela função empreendedora. Pior que isso, importantes cientistas com capacidade de rebater às falsas argumentações, mostrando as mazelas resultantes do funcionamento de tais empreendimentos, dificilmente são convidados para ponderar sobre o assunto diante do público que precisa conhecer o projeto e poder dar sua opinião. Ou por interesse político, ainda que discutido, e revelada a contrariedade do povo, tais empreendimentos se ratificam.

Acredita-se que, dentre outras maneiras, é desse modo que os idealizadores fetichizam as condições para a ratificação desses empreendimentos, ainda que eles contrariem a vontade

\footnotetext{
${ }^{5}$ BELCHIOR, Paulo Roberto Mendes. Gerente de Departamento do Meio Ambiente da Companhia Hidro Elétrica São Francisco (Chesf). Entrevista concedida a Regnaldo Gouveia dos Santos. Recife/PE, 10 de janeiro de 2014. Afirmou que "São demandas que muitas vezes não é uma... um impacto ambiental direto do empreendimento, mas o empreendedor, no mínimo, ele serve de porta-voz e... de uma ferramenta aí pra se buscar essas melhorias".
} 
do povo envolvido na área de influência. Com outras palavras, pode-se dizer que promovem algo mirabolante por vias do caráter fetichista, "ilusão socialmente, necessária" (ADORNO, 1969, p. 5). Assim, tais idealizadores coisificam a ideia de desenvolvimento, causando no povo a ilusão que desperta o interesse pelo projeto, visando alcançar seus objetivos, isto é, a instalação de seus empreendimentos hidroelétricos, por exemplo.

Enfim, cabe frisar que se buscou, ao longo de todo o contexto desenvolvido, interpretar o "espaço total", no qual a abordagem não se restringiu ao espaço físico ou social, mas conjugou os dois, conferindo o espaço geográfico como um todo.

Com essa interpretação, através da análise da paisagem, chegou-se à conclusão de que a Área de Influência Real de Empreendimentos Hidroelétricos do Ponto de Vista da Geografia não se limita à bacia hidrográfica do rio interferido, mas vai além desta até aonde o impacto ambiental ou socioambiental se confirmar.

Observou-se que definidos os critérios representados com as características físicas do espaço geográfico, bem como a bacia hidrográfica e os divisores de água, abrangendo o clima e a vegetação, foi possível conceituar o critério impacto socioambiental a partir do processo de correlação existente entre os seres vivos e o meio ambiente. As variáveis deste critério se definiram com o uso e a qualidade da água. A partir da abordagem dos critérios destacados e de suas variáveis, ora também consideradas critérios para definir aqueles dois em destaque, o presente estudo se ratificou no campo da Geografia, na área da previsão de impactos. Neste caso, é importante destacar que, por um lado, a bacia hidrográfica como um todo e os divisores de água referentes ao seu rio principal são únicos, por outro lado, as características fitogeográficas e climáticas, segundo seu vínculo de existência, variam de acordo com a dimensão espacial de tal rio, seja o São Francisco ou o Nilo. Igualmente, a água e seu uso variam, respectivamente, em qualidade e quantidade conforme as condições ambientais em 
termos de poluição ou volume do fluxo fluvial, entre outras circunstâncias, assim como destinação, finalidade.

Esses foram os objetivos alcançados que embasaram a definição da Área de Influência Real de Empreendimentos Hidroelétricos do ponto de vista da Geografia considerando todos aqueles critérios como variáveis da paisagem.

Foi desse modo também que se verificou e ratificou a hipótese que questiona como a Airehg se configura no espaço geográfico, levando em conta as paisagens natural e cultural vinculadas a um rio interferido por empreendimento hidroelétrico, seja o São Francisco ou o Nilo, por exemplo.

Ou seja, a definição de referida área de influência se revelou, de modo que foi necessário haver a inter-relação entre os seres vivos e o meio ambiente no espaço geográfico, onde se confirmou o resultado da dimensão que o impacto socioambiental pode alcançar.

Noutras palavras, a abordagem das características físicas do espaço geográfico e dos impactos ambiental e socioambiental foi decisiva ao discernimento da Airehg em relação às áreas de influência diretas e indiretas, asseguradas no EIA/Rima de empreendimentos hidroelétricos.

Tratando-se desse tema é importante também considerar que cada caso é um caso, isto é, para definir referida área é preciso estudá-la e ter todo o cuidado com a detecção dos citados impactos, pois é sua dimensão espacial de abrangência que determina a área de influência real.

Neste trabalho, o caso de Xingó é apresentado como exemplo de "área de influência real” segundo a concepção da Geografia (Ab`Sáber), embora também seja possível observar que o mesmo ocorre nos demais empreendimentos hidroelétricos do São Francisco, desde Três Marias, Sobradinho, Luiz Gonzaga (antiga Itaparica), Complexo Paulo Afonso I, II, III e IV até Moxotó. 


\section{O PROBLEMA DO AJUSTE NO ESTUDO DE IMPACTO AMBIENTAL (EIA) EM RELAÇÃO À ÁREA DE INFLUÊNCIA REAL}

O presente capítulo levanta uma questão bastante relevante do ponto de vista da Geografia, tendo em vista que esta ciência representa um conhecimento do espaço geográfico que a Lei de Política Nacional do Meio Ambiente reconhece. No entanto, esta não prima sobre a Área de Influência Real de Empreendimentos Hidroelétricos do ponto de vista da Geografia, deixando, com isso, evidências de um necessário ajuste do aporte legal a respeito do referido tema. Certo de que este é algo novo, o Estudo de Impacto Ambiental, Relatório de Impacto Ambiental (EIA/Rima) não considera referida área de influência real quando da execução deste documento à custa dos empreendedores. Assim, faz-se uma abordagem da tripartição entre o disposto na referida lei, o que tem sido cumprido no documento apresentado para o licenciamento da usina hidrelétrica e a concepção científica do ponto de vista da Geografia. O resultado dessa análise vem contribuir com o contexto do primeiro capítulo, de modo que corrobora o cerne do presente estudo. 


\subsection{A CONSIDERAÇÃO DA ÁREA DE INFLUÊNCIA REAL DE EMPREENDIMENTOS} HIDROELÉTRICOS DO PONTO DE VISTA DA GEOGRAFIA: um caminho visando solucionar o problema existente entre o que emana da Lei de Política Nacional do Meio Ambiente e o que prima o EIA/Rima

O problema de ajuste que se trata, conforme sua abordagem a seguir é, em termos, complexo, haja vista que, por um lado, o estudo de impacto ambiental custeado pelo empreendedor deixa a desejar quanto à definição da Área de Influência Direta (AID) e da Área de Influência Indireta (AII). Isso foi observado quando tal estudo foi confrontado com o que emana da Lei de Política Nacional do Meio Ambiente (Lpnma), Lei nº 6.938/1981.

Por outro lado, esta mesma lei que apresenta exigências aparentemente adequadas em relação ao estudo de previsão de impactos, visando à prevenção dos impactos ambientais e sociomabientais, deixa evidências de que precisa passar por um processo de ajuste. Tal processo gira em torno do ajuste da lei, de modo que se passem a emanar diretrizes capazes de definir a área de influência real do ponto de vista da Geografia, referente a qualquer tipo de empreendimento hidroelétrico causador de impacto ambiental, levando a cabo a dimensão espacial que seus efeitos alcançam direta ou indiretamente.

Refletir sobre o problema de ajuste do EIA é relevante do ponto de vista acadêmico, socioambiental e legal.

Entre outras justificativas, a respeito desse tema na academia, ressalta-se a reafirmação da ideia de "espaço total" defendida por Ab’Sáber. Referida ideia embasa, fundamentalmente, a concepção da Área de Influência Real de Empreendimentos Hidroelétricos do ponto de vista da Geografia (Airehg). Esta é uma das tripartes que engloba o complexo problema representado no tema em epígrafe.

Certo de que a abordagem desse assunto venha instigar a interpretação de uma área de influência à altura da necessidade de se observar o espaço no estudo da previsão de impactos, a relevância do tema se justifica na Geografia. 
A referência dada à academia, deve-se ao fato de ser necessário manter essa discussão, enfatizando o senso da Airehg nas universidades, até mesmo após confirmado o ajuste das leis que regulamentam o EIA. Uma das razões dessa perpetuação é que prever impactos não se restringe ao tempo presente, mas precisa considerar este tempo, além do passado e também do futuro a curto, médio e longo prazo. Desse modo, podem ser evitados equívocos ou enganos sobre qualquer boa percepção de um meio ambiente, aparentemente, preservado no presente. Um exemplo é que, neste caso, muitas vezes deixam de se pensar na maneira de manutenção, preservação e boa gestão desse espaço devido a tal aparência.

Manter a discussão nas universidades sobre a Airehg relacionado-a ao tema em epígrafe representa um papel importante do ponto de vista do contexto socioambiental.

É justamente dessas instituições científicas que partem importantes meios de direcionamento de políticas que podem promover a boa relação entre a sociedade e a natureza.

À sociedade importa o cuidado com a natureza a fim de assegurar as possibilidades da vida dos seres, inclusive, do próprio homem. Daí por que o ajuste do EIA é de interesse social, ou seja, à medida que o EIA/Rima considerar a Airehg, poderão ser obtidos significativos ganhos para o meio socioambiental. Nessa concepção, desenvolver de maneira sustentável significa engendrar um desenvolvimento conciliado e condicionado aos moldes de uma economia capaz de se realizar em comunhão com a preservação ambiental e a participação de toda a sociedade, sem exceção.

O tema em epígrafe também se justifica numa perspectiva legal, tendo em vista que, no caso do Brasil, precisa haver um ajuste da lei de regulamentação do EIA/Rima, do conjunto da Lpnma.

Este é um dos principais fatores direcionados para a solução do problema e denota-se que o mesmo fator está atrelado ao termo social, pois só o homem é capaz de criar as leis e também executá-las. 
Além disso, não bastassem o aspecto acadêmico com a ideia da Airehg e a sociedade em geral, demonstrando interesse pelo desenvolvimento sustentável, referido problema jamais seria resolvido.

Mediante o contexto da abordagem feita, observa-se que uma das justificativas mais enfáticas do problema de ajuste no Estudo de Impacto Ambiental é o descompasso existente entre o EIA/Rima apresentado pelo empreendedor, a Airehg e o que emana da Lpnma.

Nesse sentido, o primeiro capítulo evidenciou o caso ocorrido com os empreendimentos hidroelétricos. O contexto com o qual se realizou a abordagem em referido capítulo tem importante valor representativo sobre os casos analisados. Isso vale também para toda e qualquer execução empreendedora causadora de impacto ambiental e ou socioambiental, ou seja, não se restringe ao empreendimento hidroelétrico, porém, este foi o que se destacou no estudo de caso.

O problema a que se refere passou a ser notável após serem analisados, de um lado, a Lei de Política Nacional do Meio Ambiente, e do outro, o Estudo de Impacto Ambiental Relatório de Impacto Ambiental (EIA/Rima) de Xingó, último empreendimento hidroelétrico a jusante do Rio São Francisco, por exemplo, documento apresentado sob responsabilidade do empreendedor. Dessa observação, passou-se a perceber que os outros empreendimentos a montante, também têm relação com o fenômeno estudado em função de suas conexões através do fluxo fluvial.

A abordagem do tema em epígrafe parte da contribuição de pensadores da geografia russa e da alemã, voltando-se para a análise geo-histórica do EIA/Rima até ser instituído no Brasil.

O que se conhece no Brasil como Estudo de Impacto Ambiental, segundo Burman e Danilov-Danilkhan (2006, p. 195): "Na Rússia, o termo empregado é Ozenka Wosdeisstwikha 
na Okruschakhuschtschukhu Ssredu (OWOS), que pode ser traduzido aproximadamente por Avaliação da Ação sobre o Meio Ambiente".

Comparada ao Brasil, a elaboração dessa documentação na Rússia mostra-se de forma “democrática", em termos, tendo em vista que, conforme Dubinina e Lablokov (2006, p. 299):

O EIA (em russo: OWOS) é um processo complexo no qual se decide o destino de um projeto com base nos conhecimentos de especialistas e na opinião de pessoas comuns. Essa união de esforços dos cientistas e dos meios sociais resulta da intensa luta com os detentores do poder, que se apropriam do monopólio do direito de tomar decisões.

A análise feita sobre a geografia russa indica que, apesar das dúvidas sombreando a transição do século passado para o presente em função da mudança legislativa, foi na então União das Repúblicas Socialistas Soviéticas (Urss) (década de 1980) que se criou o Comitê Estatal para a Proteção da Natureza no ano de 1987.

Certamente, esse foi o período que marcou a institucionalização do EIA, conhecido pelos russos como Avaliação da Ação sobre o Meio Ambiente (na linguagem russa corresponde à sigla Owos). As dúvidas a que se referem são em relação às significativas mudanças ocorridas na Rússia por causa do desmembramento dos vários Estados que constituíam a Urss. Isso conduziu aquele país a uma fase de transição quanto à sua legislação, pois leis antigas já não podem vigorar devido ao episódio da desestruturação territorial da extinta União Soviética.

Na Federação Russa, segundo Maksimenko (2006, p. 221):

Para a assimilação da metodologia do estudo de impactos ambientais na fase de preparação de decisões econômicas, promovem-se seminários, conferências e cursos e preparam-se manuais para os iniciantes. [...] Ao mesmo tempo, não se pode dizer que a assimilação da metodologia do EIA decorre sem dificuldades e incompreensão da parte dos que encomendam e dos que elaboram os projetos.

Nesse sentido, pode-se perceber que a efetivação do EIA não é tão simples e tampouco expressa a plena democracia na sua elaboração. 
Ratificam-se as assertivas acima, conforme bem observou Burtsev (2006, p. 282): “O EIA é realizado pela organização responsável pelo projeto, que, em caso de necessidade, convida para esse trabalho organizações de investigação científica e de estudo de terrenos, bem como especialistas na matéria”.

Já a análise que se faz do ponto de vista da geografia alemã, se sobressai na abordagem da origem da regulamentação legal sobre o EIA da antiga Alemanha Ocidental (República Federal da Alemanha) e, a posteriori, da antiga Alemanha Oriental (República Democrática Alemã). Esse instrumento de política ambiental é conhecido e denominado Umweltvertäglichkeitprüfung (UVP), traduzido para português como Estudo do Impacto Ambiental ou Análise do Impacto Ambiental.

A consciência ambiental caracterizou o território desses dois países europeus (atual Alemanha) por volta de 1970, período marcado pela criação da Lei da UVP que só foi regulamentada em 1991.

No entusiasmo de tal consciência, de acordo com Schlüpmann (2006, p. 364):

Em 1971, surge também o primeiro programa ambiental do governo alemão [do lado ocidental], publicado em 1972 em brochura, com prefácio e retrato (da pintura feita por Friedrich Naumann) de Hans Dietrich Genscher, o então ministro (do Interior) em exercício. Em 1972, realizou-se também a Conferência de Proteção das Espécies de Estocolmo.

Coincidência ou não, só se sabe que, praticamente no mesmo período, mais precisamente no ano de 1969, se originou, nos Estados Unidos, algo como a Lei de Política Nacional do Meio Ambiente (National Environmental Policy Act (Nepa)) e o EIA (Environmental Impact Assessment (EIA)). Por fim, logo depois foi fundada a Agência de Proteção ao Meio Ambiente (Environmental Protection Agency (EPA)). Isso é possível conferir conforme observou Schlüpmann (2006, p. 364):

Em 1969, o congresso americano, após um período de discussão extraordinariamente curto, votou o National Environmental Policy Act (NEPA) e decretou um Environmental Impact Assessment (EIA). Pouco depois, no curso da reorganização dos serviços públicos da administração 
Nixon, foi fundada a EPA, a Environmental Protection Agency (Agência de Proteção ao Meio Ambiente).

O fato que chama a atenção, considerando as observações acima, dá referência às críticas que especialistas dirigem tanto à lei americana, quanto à alemã, por exemplo, para Schlüpmann (2006, p. 366-367):

Evidentemente, a UVP, juntamente com o NEPA, virou tema também na Europa; na Alemanha isso ocorreu na verdade sob condições totalmente diferentes: o que nos EUA representava uma ruptura com a tradição correspondia, na tradição alemã, a um momento paternalista e administrativo, que envolvia a implantação de grandes projetos, desde a produção de energia até a construção de rodovias.

As críticas dirigidas à Lei da UVP não se referem à perfeição do documento, mas levantam questões que representam suas fragilidades ou flexibilidades.

Nesse sentido, de acordo com Bunge (2006, p. 405): "Não se pode esquecer, entretanto, que a Lei da UVP contém apenas determinações mínimas. Portanto, existe a possibilidade da introdução de regulamentações mais amplas em leis federais e especialmente na esfera estadual".

Nos termos dessa abordagem, enfatizando a geografia alemã e no intuito de melhor conhecer o instrumento de política ambiental da Alemanha, é importante salientar que, segundo Summerer (2006, p. 409):

O objetivo da lei é garantir que, em UVP de projetos, os impactos ambientais sejam detectados com antecedência e de forma global, bem como descritos e avaliados de acordo com princípios uniformes. A lei visa também garantir que o relatório seja levado em consideração no momento da autorização do projeto. Somente assim podem ser tomadas as medidas necessárias a uma proteção efetiva do meio ambiente.

Enquanto Bechmann e Hartlik (2006, p. 499) asseguram que, “A função política do Estudo de Impacto Ambiental reside na preparação para a tomada de decisões. A UVP tem como objetivo identificar, em termos teóricos, os possíveis efeitos ecológicos envolvidos na realização de determinados projetos e avaliar suas consequências ambientais”. 
Zeretzke (2006), ao se referir à relação existente entre o EIA (em alemão, UVP) e à mudança de instrumentos legais, defende que a Lei da UVP chega a ser ampla e eficaz, em termos de proteção ao meio ambiente. Contudo, foi possível notar também na leitura do autor que, a esse respeito, há um descompasso, tendo em vista que segundo ele a maioria das pessoas respeita o aporte legal, embora as empresas, os produtores e organizadores da produção provoquem os impactos ambientais.

Por essas e outras razões é que o ajuste da lei ambiental se apresenta como um problema e que também tem de ser resolvido urgentemente, pois de acordo com Zeretzke (2006, p. 524):

O sistema político não pode deixar de perceber tais comportamentos; os temas são agitados no âmbito das instituições políticas, obrigando o surgimento de legislações mitigadoras. [...] Caso o surgimento dos instrumentos legais acompanhasse a velocidade da destruição do sistema ecológico, talvez isso fosse tranqüilizante, no entanto, aumenta o buraco de ozônio, o efeito estufa, diversas faixas do mar estão morrendo e grandes zonas florestais vêm sendo aniquiladas, catástrofes todas que ocorrem com mais rapidez do que a legislação de proteção pode acompanhar.

Lamentavelmente, deduz-se que nosso princípio de 'proteção ao meio ambiente' e os métodos para colocá-lo em prática com os meios obtidos até agora não são suficientes para assegurar a sobrevivência.

No mínimo, pode-se interpretar, com isso, a fundamentação do ajuste das legislações no intuito de acatar o que o presente estudo revela sobre a área de influência real de empreendimentos hidrolétricos do ponto de vista da Geografia, sua consideração por parte do EIA/Rima.

Além dos territórios dos citados Estados-Nação que regulamentaram o EIA e o implementaram à luz de suas leis, merece destacar o território brasileiro por também possuir uma lei específica a esse respeito e, sobremaneira, representar a área de estudo.

No Brasil, a Lei 6.938/81 entrou em vigor em 1981 e dispõe sobre a Política Nacional do Meio Ambiente. Por um lado, de acordo com o artigo $9^{\circ}$, inciso III da citada lei, a Avaliação de Impactos Ambientais (AIA) é um dos instrumentos da Política Nacional do Meio Ambiente. O Estudo de Impacto Ambiental aparece na Resolução nº 01/1986, instituída 
pelo Conselho Nacional do Meio Ambiente (Conama), sendo esse o marco geo-histórico (consideração do tempo e espaço de constituição) do referido documento no Brasil, dado que, em termos internacionais, esse instrumento legal já se institucionalizara nos EUA em 1969. Por outro lado, o artigo $6^{\circ}$, incisos II e IV da lei supracitada, estabelece o Sistema Nacional do Meio Ambiente (Sisnama) constituído por, dentre outros órgãos, o Conama, de poderes consultivo e deliberativo e o Instituto Brasileiro do Meio Ambiente e dos Recursos Naturais Renováveis (Ibama), com a função de executor.

Assim, cabe esclarecer que o Conama tem poder deliberativo, haja vista ao seu ato, por exemplo, em determinada discussão, de maneira que compete ao conselho da corporação institucional resolvê-la após exame. Já o seu aspecto consultivo, caracteriza-se pelo fato de não ter como obrigatoriedade a exigência do voto deliberativo quando da emissão de parecer sobre assunto tratado pelo órgão. Enquanto isso, o Ibama tem a função de se fazer cumprir a lei, ou seja, de levá-la a efeito.

A presente pesquisa não faz uma avaliação de impacto ambiental, por isso não usou o instrumental AIA, deste campo de estudos.

Noutros termos, o que está em discussão não é a avaliação do impacto ambiental, mas a dimensão que este e o impacto socioambiental podem alcançar, razão pela qual foi feita toda a abordagem geo-histórica sobre o EIA.

As resoluções do Conama $n^{\circ}$ 01/86, $n^{\circ}$ 23/86, no 24/86 e no 06/87 dão referência ao assunto que trata das usinas hidrelétricas no Brasil. Em função do tema em epígrafe, dessas resoluções, a primeira e a última serão enfatizadas. O primeiro desses documentos dispõe sobre o EIA/Rima.

Assim, denota-se que esse instrumento da política ambiental foi instituído no Brasil a partir da Resolução Conama n ${ }^{\circ}$ 01/86. 
De acordo com Milaré (2006, p. 53), “O objetivo central do estudo de impacto ambiental é simples: evitar que um projeto (obra ou atividade), justificável sob o prisma econômico ou em relação aos interesses imediatos de seu proponente, se revele, depois, nefasto ou catastrófico para o meio ambiente".

Muito além disso, do ponto de vista da Geografia, "Prever impactos em relação a um projeto de qualquer tipo, destinado a uma determinada região e a um sítio ou gleba em particular, é uma operação técnico-científica essencialmente multidisciplinar, de grande importância para os países do Terceiro Mundo." (AB'SÁBER, 2006a, p. 27). Igualmente, é preciso levar em conta o que bem observou Ab’Sáber e Müller-Plantenberg (2006, p. 567568):

O processo de prever impactos é mais do que uma ciência, já que envolve combinações diferenciadas de campos do conhecimento; tendo ainda uma vinculação total com a ética. Uma ética com o presente que se projeta para o futuro, respaldada no que aconteceu de certo ou muito errado no passado. Razão pela qual o processo de previsão de impactos em projetos (que venham de onde vier) implica uma espécie de arte-ciência, ou uma précondicionante filosófica. Trata-se de um exercício muito sério que pressupõe uma atenção em diferentes escalas espaciais, que transicionam do planetário ao local envolvendo continentes e oceanos, jogo das massas de ar, conjunturas das ações antrópicas modificadoras e interferentes na organização herdada da natureza.

Assim como os outros protocolos legítimos dos países anteriormente abordados, o brasileiro é também passível de crítica conforme se percebe ao confrontar o artigo $7^{\circ}$ com o artigo $8^{\circ}$ da mesma Resolução Conama $n^{\circ}$ 01/86. Ou seja, incorre ao que argumentou Milaré (2006, p. 71) sobre "o florescimento da chamada 'indústria do EIA/RIMA' pelos escritórios de consultoria privada, marginalizando os técnicos vinculados ao empreendedor, muitas vezes os mais competentes e bem informados a respeito da situação objeto do estudo”.

Em outros termos, entende-se que esse é um dos problemas de ajuste da Lpnma, pois, mormente, um outro chama ainda mais a atenção quanto ao descompasso existente entre o aporte legal, o EIA/Rima de Xingó e a consideração do ponto de vista da Geografia em relação à Área de Influência (AI) de empreendimentos hidroelétricos, por exemplo. 
Nessa concepção, basta observar a legislação a seguir e compará-la ao que foi acatado, segundo Santos (2008), sobre a AI do empreendimento de Xingó e logo perceberá tal descompasso.

Destaca-se na Resolução Conama nº 01/86:

Art. $5^{\circ}$ - O estudo de impacto ambiental, além de atender à legislação, em especial os princípios e objetivos expressos na Lei de Política Nacional do Meio Ambiente, obedecerá às seguintes diretrizes gerais:

III - Definir os limites da área geográfica a ser direta ou indiretamente afetada pelos impactos, denominada área de influência do projeto, considerando, em todos os casos, a bacia hidrográfica na qual se localiza; [...].

Conforme a Lei $\mathrm{n}^{\circ}$ 6.938/1981:

Art. $3^{\circ}$ - Para os fins previstos nesta Lei, entende-se por:

II - degradação da qualidade ambiental, a alteração adversa das características do meio ambiente;

III - poluição, a degradação da qualidade ambiental resultante de atividades que direta ou indiretamente:

a) prejudiquem a saúde, a segurança e o bem-estar da população;

b) criem condições adversas às atividades sociais e econômicas;

c) afetem desfavoravelmente a biota;

d) afetem as condições estéticas ou sanitárias do meio ambiente;

Art. $4^{\circ}$ - A Política Nacional do Meio Ambiente visará:

I - à compatibilização do desenvolvimento econômico-social com a preservação da qualidade do meio ambiente e do equilíbrio ecológico; [...].

Tendo em vista que o EIA/Rima do citado empreendimento apresentou sua área de influência muito insignificante em relação ao espaço afetado pelos impactos ambientais dentro da bacia hidrográfica de acordo com Santos (2008), e considerando que, com isso, não cumpriu o artigo $5^{\circ}$, inciso III da Resolução Conama $n^{\circ}$ 01/86, foi, portanto, ratificado, o referido descompasso. Tal descumprimento confirmou-se em função do artigo $4^{\circ}$, inciso I da supracitada lei também não ter sido levado a efeito devido ao desequilíbrio ecológico que o espaço fluvial Sãofranciscano vem sofrendo por causa da operação dos empreendimentos hidroelétricos. Estes são causa da poluição ambiental, o que está em desacordo com o artigo $3^{\circ}$, incisos II e III, alíneas a, b, c, d, da referida lei.

O que justifica toda essa argumentação, é o fato de a Usina Hidrelétrica Xingó ter entrado em operação após a Resolução Conama nº 01/86 passar a vigorar. 
É importante também destacar a responsabilidade do Estado a respeito do seu papel de fiscalizador e executor conforme está bem representada a seguir, de acordo com a Resolução Conama $n^{\circ}$ 06/87 (grifo nosso):

Art. $9^{\circ}$ - O estudo de impacto ambiental, a preparação do RIMA, o detalhamento dos aspectos ambientais julgados relevantes a serem desenvolvidos nas várias fases do licenciamento, inclusive o programa de acompanhamento e monitoragem dos impactos, serão acompanhados por técnicos designados para este fim pelo(s) órgão(s) estadual(ais) competente(s).

Art. 12 - O disposto nesta Resolução será aplicado, considerando-se as etapas de planejamento ou de execução em que se encontra o empreendimento.

$\S 4^{\circ}$ Para o empreendimento que entrou em operação a partir de $1^{\circ}$ de fevereiro de 1986, sua regularização se dará pela obtenção da LO [Licença de Operação] para a qual será necessária a apresentação de RIMA contendo, no mínimo, as seguintes informações: descrição do empreendimento; impactos ambientais positivos e negativos provocados em sua área de influência; descrição das medidas de proteção ambiental e mitigadoras dos impactos ambientais negativos adotados ou em vias de adoção, além de outros estudos ambientais já realizados pela concessionária.

Sobretudo, segundo o que emana da Lei ${ }^{\circ}$ 6.938/1981 (a qual antecede a supracitada resolução):

Art. 14 - Sem prejuízo das penalidades definidas pela legislação federal, estadual e municipal, o não cumprimento das medidas necessárias à preservação ou correção dos inconvenientes e danos causados pela degradação da qualidade ambiental sujeitará os transgressores:

IV - à suspensão de sua atividade.

As exigências para a realização e apresentação do EIA/Rima de empreendimentos hidroelétricos com potencial acima de $10 \mathrm{MW}$ partem de seus financiadores internacionais como o Banco Mundial, entre outros.

Neste caso, cabe ressaltar que para Müller-Plantenberg (2006, p. 557):

Com a crise energética, o processamento da matéria-prima passou a ser realizado cada vez mais no próprio país, para se economizar nos dispendiosos custos energéticos do transporte. Entretanto, tal fato não contribuiu para uma sempre tão sonhada maior independência econômica dos Estados, mas sim para uma maior sobrecarga sobre o meio ambiente e ameaças às populações regionais.

Essa concepção vem corroborar a pressão dos países ricos e a sobreposição de seu poder nas economias dos países pobres, sobretudo, refletindo de forma negativa no meio ambiente 
destes em função de suas leis ambientais vulneráveis à crítica ou até à contradição conforme observou Milaré (2006).

Ratificam-se as assertivas acima conforme Teixeira et al. (2006, p. 168):

As primeiras tentativas de uso da avaliação de impacto ambiental no Brasil foram feitas por exigência de órgãos financeiros internacionais, como o Banco Mundial, que sujeitaram seus empréstimos a uma análise dos efeitos ambientais dos programas do governo. Logo a seguir, os estudos de impactos foram reclamados como parte das informações fornecidas por atividades poluidoras aos sistemas de licenciamento e aprovação do projeto.

Da análise da pesquisa, notou-se que o instrumento legal da política ambiental dos vários Estados-Nação apresentou uma demanda por ajuste de suas leis regulamentares. Ou seja, vê-se que há uma necessidade de ajuste do aporte legal de cada um dos países conforme a abordagem feita.

Com relação ao Brasil, onde se realizou o estudo de caso, o que chamou mais a atenção foi o descompasso existente entre a Lei 6.938/1981, que regulamenta o EIA/Rima, e este documento apresentado por parte da Usina Hidrelétrica Xingó, que também não considerou a Airehg.

Posto isto, cabe frisar o fato novo levantado graças à abordagem que se realizou, conforme segue.

Neste caso, ainda que todo e qualquer empreendimento hidroelétrico com o potencial acima citado possua EIA/Rima nos parâmetros das Resoluções Conama nº 01/86 e nº 06/87, a necessidade da Lpnma ser ajustada se ratifica, pois, ao que se sabe, não há no Brasil nenhum empreendimento desse tipo e porte que considere a Airehg conforme foi definida no primeiro capítulo. Isso se deve ao fato de áreas de fora da bacia hidrográfica do rio interferido, que a este estão ligadas, sofrerem impactos socioambientais quando os impactos ambientais se confirmam no ecossistema fluvial.

O problema de ajuste do EIA que não deixa de ser da Lpnma (consequentemente, em função do EIA depender desta lei) não se restringe apenas ao descompasso observado em 
termos legais, algo como a possibilidade do aspecto contraditório na lei, assim como foi mencionado anteriormente. Entretanto, não se pode deixar de enfatizar, sobremaneira, que tal problema se configura também devido ao fato do EIA/Rima, neste início de século (XXI), ainda não ter adotado como a AI do empreendimento a Airehg.

Nessa concepção, é relevante levar em conta o contexto de como o avanço técnico-científico reflete na discussão desta área de influência real. Isto é, conforme importantes pensadores trataram do tema do termo destacado nos seus moldes de abordagem, assim como Milton Santos (1996) e David Harvey (1992), cabe esclarecer o seguinte: ao longo do tempo a função do espaço fluvial Sãofranciscano passou por transformações.

Se num primeiro momento o uso da água para abastecimento público, entre outras necessidades, ocorria por tração humana, animal ou outros meios de transporte antes de existirem as hidrelétricas do Vale São do Francisco, logo após a execução e a atividade destas, passou a ser usada a tecnologia para o mesmo fim, levar água às comunidades, além de outras funções como a geração de energia, prática da irrigação.

Noutro momento, percebe-se que a tecnologia se confirma através do aperfeiçoamento da técnica em levar água cada vez mais distante, segundo a necessidade do homem, graças ao conhecimento científico, por exemplo, como gerar energia para conduzir a água até aonde o povo se encontra.

Tudo isso reforça a ideia de que, pensar na área de influência real de empreendimento hidroelétrico do ponto de vista da Geografia, remete à reflexão do termo avanço tecnológico, pois é em função deste, nos termos acima citados, que referida área transcende a bacia hidrográfica do rio interferido pelo empreendimento hidroelétrico.

Assim, fica evidente que, se os técnicos responsáveis pela elaboração do EIA/Rima levassem em conta o avanço tecnológico aqui abordado e como deve sê-lo, o reconhecimento da referida área de influência real não implicaria em um problema de ajuste no EIA. 
Outro aspecto que merece ser retomado, de maneira breve, neste caso, é a contaminação da água que resulta na alteração hormonal do sistema endócrino humano, principalmente, tratado no primeiro capítulo. Ou seja, referida poluição afeta a água por causa de resíduos químicos usados na agricultura em função do avanço tecnológico. Para piorar a situação, o tratamento de água convencional não é capaz de eliminar as substâncias que geram tal poluição. Daí por que a importância de relacionar o avanço tecnológico à interpretação da Airehg, pois sua dimensão espacial está ligada aos impactos ambientais que, entre outros fatores, resultam da tecnologia (uso de substâncias químicas, por exemplo, entre outras circunstâncias) a partir da ação humana. Não se pode deixar de destacar que tudo isso se agrava ainda mais em áreas de água parada ou de pouca correnteza, fator marcante nas barragens hidrelétricas ao longo do Rio São Francisco, conforme constatado na análise da pesquisa.

Desse modo, pôde-se observar que a maneira com a qual o texto foi contextualizado veio ratificar o objetivo alcançado. Por isso, foi possível revelar como a falta de consideração da Airehg, por parte do EIA/Rima, se configurou em um problema de ajuste no referido documento.

Em função disso, ao verificar as hipóteses, chegou-se às conclusões a seguir.

Verificou-se que a Resolução Conama 01/86 determina: o EIA/Rima tem de considerar a bacia hidrográfica ao delimitar a AI do empreendimento hidroelétrico com potencial acima de 10 MW. Apesar disso, o caso do estudo sobre os impactos socioambientais às margens do Rio São Francisco, de acordo com Santos (2008), revelou que parte desse espaço fluvial não foi levada em conta. Razão pela qual foi possível observar o descompasso que há entre as considerações do EIA/Rima de responsabilidade do empreendedor sobre a área de influência do empreendimento, as diretrizes a partir da Lpnma, e a interpretação do elemento espacial do ponto de vista da Geografia. 
Consequentemente, denota-se que tudo isso se deve ao fato de o EIA/Rima não considerar a Airehg. Tendo em vista seu processo geo-histórico, o fato desse instrumento de política ambiental considerar a Airehg implica em resolver o problema de ajuste que se definiu no desenrolar deste trabalho.

Diante do que está posto, agora fica a cargo do poder público institucional tomar as medidas políticas e, inclusive, se disponibilizam possibilidades para que a sociedade como um todo conheça e opine sobre a questão, buscando caminhos para sanar a necessidade que se vislumbrou com o presente estudo. Certo de que, ao ajustar a Lpnma segundo o que pretendeu a abordagem da presente pesquisa, este procedimento poderá ser o limiar de convenções internacionais a respeito do EIA conforme o texto foi fundamentado.

Desse modo, dependendo de suas condições, o Brasil poderia alterar suas normas, em função da nova definição que se revelou, pois esse fato tende a lhe trazer destaque internacional ante a crise ambiental do mundo contemporâneo. Tal medida é substancial aos termos do desenvolvimento sustentável, visto que a dimensão espacial da área de influência real inibe, teoricamente, qualquer possibilidade do alastramento do impacto ambiental ou socioambiental, pois referida dimensão espacial abrange até onde esses tipos de impactos alcançarem. O advérbio teoricamente, referido acima, é mencionado em função de que, praticamente, muito poderá ser resolvido por implementação de ações públicas e, sobretudo, pela execução de políticas ambientais, mais diretamente voltadas ao assunto, pondo em prática planos efetivos a curto, médio e longo prazo. 


\section{O RIO SÃO FRANCISCO: alguns aspectos semelhantes e comuns em relação ao Rio}

Nilo

A abordagem deste capítulo gira em torno da interpretação do tema em epígrafe a partir da análise da paisagem. Traz como exemplo o caso do Rio São Francisco em relação a alguns aspectos semelhantes e comuns ao Rio Nilo. Embora o estudo trate da bacia hidrográfica do rio brasileiro, do alto ao seu baixo curso, é nesta última parte fluvial que se revelam, de maneira mais enfática, tais aspectos em relação ao baixo curso do rio africano. Se, por um lado, as características naturais dos dois cursos fluviais se assemelham bastante ao longo de seus espaços geográficos, por outro, em termos de uma percepção prospectiva de seus territórios, percebe-se uma ligeira diferença em função da modernização do espaço. Isto é, o Rio São Francisco passa por um processo de transformação, que se diga, muito mais agressivo que o do Nilo, concernentemente à transposição das águas daquele. Entre outras circunstâncias e a partir do que se refere ao rio brasileiro, foram observados os critérios indispensáveis ao conceito e ratificação do cerne do presente feito confirmado no primeiro capítulo. 


\subsection{O ESPAÇO GEOGRÁFICO DO RIO SÃO FRANCISCO EM RELAÇÃO AO DO RIO}

NILO: uma interpretação da paisagem

Através da análise das paisagens natural e cultural que, por fim, são atributos do espaço total observado por Ab’Sáber (2006a), com o qual Falcão Sobrinho (2007) concorda ao analisar a paisagem em termos de um olhar empírico, é possível abordar como os espaços geográficos dos rios São Francisco e Nilo vêm se organizando ao longo do tempo.

Percebe-se que, por meio do olhar sobre a paisagem, é notável como as coisas do espaço vão procurando posições (possivelmente, seus lugares) estáticas ou móveis e em sintonia com essas coisas estão os seres vivos racionais e irracionais. Nesse cenário se sobressai o homem, porque possui a capacidade de pensar e de agir cultural e socialmente, além de inúmeras outras vantagens. São as condições da ação e organização que chamam a atenção, entre outros fatores, pois graças a esses aspectos humanos é que, ao longo do tempo, considerando os fatores natural e humano, o espaço geográfico vem se configurando, de maneira dinâmica.

Conforme esse contexto, a organização socioespacial dos rios São Francisco e Nilo será abordada, considerando alguns aspectos, inclusive, contemporâneos, que vêm marcando suas margens.

Num primeiro momento, será feita uma abordagem que contempla a paisagem natural, assim como a descrição e análise de características físicas do espaço geográfico das bacias hidrográficas dos dois rios. Num segundo momento, abordar-se-ão as possibilidades que há na relação existente entre os seres vivos e o meio ambiente, substancialmente, entre o homem e o espaço geográfico.

$\mathrm{Na}$ situação geográfica em que esses dois rios correm, as características climáticas semelhantes se apresentam como fatores físicos e naturais que influenciaram sobre muitos costumes comuns entre os povos que habitam suas margens. 
Neste caso, considera-se aspecto semelhante aquele que está diretamente relacionado à natureza, de forma que sobre o qual não tenha havido nenhum tipo de intervenção humana. Até o presente momento não se têm evidências de que o homem tenha interferido, diretamente, em um clima na escala continental ou global, apesar de ser correto afirmar que a natureza tenha sofrido muitos impactos por causa da ação humana em escalas menores. Para que a escala continental ou global seja alcançada, vários outros meios coadjuvam com tal ato ou ação humana. Um exemplo do aspecto semelhante pode ser dado com a água oceânica que exerce forte influência na escala global, já que os oceanos ocupam o maior percentual da superfície do planeta.

O aspecto comum é considerado distinto do semelhante por sofrer algum tipo de intervenção humana, direta ou indiretamente, mas não deixa de estar contido na natureza. Nesse sentido, a cultura de determinado povo, neste caso, considerada um aspecto comum, é passível de sofrer influência de cultura diferente, isto é, de outro povo que habita uma região distante da que foi ocupada por aquele. Exemplo disso é o conjunto de pessoas de um lugar ou região que está habituado a um modo de vida urbano ou rural ao aceitar mudanças por influência cultural externa no seu espaço geográfico referentes aos seus costumes, sejam de hábitos alimentares, comportamento familiar ou social, maneira de trabalhar, entretenimento.

Note-se que o fator em discussão se refere a aspecto relativo à ação humana, pois é crível que o fato de um povo ter sofrido mudanças em seus hábitos de vivência, em razão de interferência de outras culturas, conforme acima foram mencionadas, aconteceu por causa da influência de outros seres humanos. Nessa concepção, quando há a ocorrência de animais da mesma espécie habitando lugares distintos ou distantes por terem sido inseridos em determinado habitat pelo ser humano, ou por razões deste, isso é considerado ao que se trata como algo em comum. Por exemplo, o fato de o homem inserir uma determinada espécie animal em habitat de onde a mesma não deriva, mas por ter se adaptado bem a ponto de viver 
adequadamente, significa dizer que a sua existência no seu habitat original e no outro diferente, neste caso, é considerada como algo em comum. Noutros termos, em sua essência, a espécie passou a viver noutro ambiente em função da ação humana, mas não naturalmente como acontece no caso dos enclaves, ideia defendida por Ab'Sáber (2003) a respeito da ocorrência de um tipo de vegetação em uma área de domínio de vegetação diferente.

O Rio São Francisco nasce na Serra da Canastra, região sudeste (Minas Gerais), e deságua na região nordeste (Oceano Atlântico) do território brasileiro. O Brasil é o mais importante país da América do Sul por ter a maior extensão territorial e se destacar, entre outros aspectos, pela sua economia e tecnologia. Aos olhos da civilização, o Brasil foi descoberto no ano de 1500, pelos portugueses, que também colonizaram suas terras, até 1822 , quando se tornou independente de Portugal. A partir da independência, passou por período imperial que se estendeu até a proclamação da República do Brasil em 1889, e por ser tão extenso, é considerado por muitos um país continental; essa é uma das razões pelas quais sofre influência de vários tipos de clima.

Já o Rio Nilo nasce no Burundi, país do continente africano, na região do planalto dos Grandes Lagos e atinge o lado oeste do Lago Vitória, entre a Tanzânia e Uganda, enquanto que na porção norte desse lago o rio ruma para o Mar Mediterrâneo, onde deságua em delta. Segundo Magnoli, Arbex Junior e Olic (1997) seu curso percorre $6.700 \mathrm{~km}$ (seis mil e setecentos quilômetros) desde a nascente até lançar suas águas no Mediterrâneo. Além desses três países já mencionados, fazem parte da bacia hidrográfica do Nilo: Ruanda, Quênia, Sudão do Sul e Sudão, Egito, Etiópia, República Democrática do Congo e Eritreia. Esse extenso rio é formado por afluentes de denominações como Nilo das Montanhas (região da mais distante nascente, por onde corre o rio ainda com denominação Kagera), e o Nilo Branco, que segue o curso até confluir com o denominado Nilo Azul (com nascente no planalto da Etiópia). 
Com relação aos aspectos físicos e naturais do espaço geográfico que envolve o rio brasileiro, desde a nascente até o seu estuário, o São Francisco forma sua bacia hidrográfica e drena um percentual de, aproximadamente, $7,5 \%$ do território nacional, de maneira que o curso d'água percorre cerca de 3.000 km (três mil quilômetros). Além do Distrito Federal, os Estados que abrangem essa bacia hidrográfica são Minas Gerais, Goiás (pequena parte), Bahia, Pernambuco, Alagoas e Sergipe. Sua nascente se encontra no primeiro Estado e a foz no Atlântico, entre os dois últimos.

As águas das cabeceiras do rio afloram a cerca de $1.350 \mathrm{~m}$ (metros) de altitude a partir do município São Roque de Minas/MG, onde ainda se localiza a sua primeira grande cachoeira conforme a descrição abaixo.

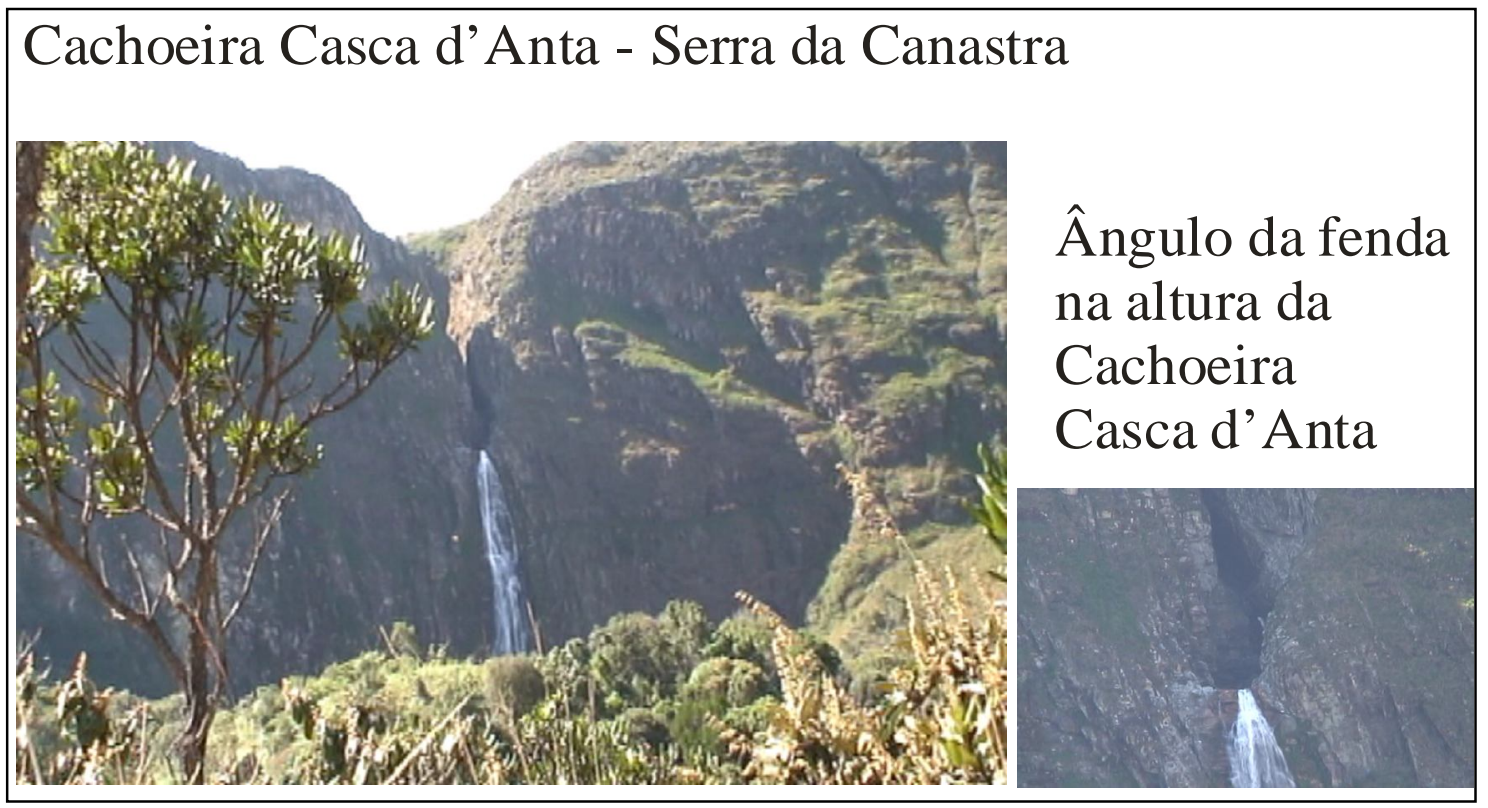

Figura 05. Cachoeira Casca d'Anta, Minas Gerais. Fonte: foto do autor, julho de $2008^{6}$.

Por um lado, a fenda notável em estrutura rochosa na chapada da Serra da Canastra, e ainda próximo da nascente, é um dos vestígios da ação fenomenal do Rio São Francisco, como também a Cachoeira Casca d'Anta, que deslumbra qualquer observador que contemplar a paisagem do parque ecológico de mesma denominação da referida serra.

\footnotetext{
${ }^{6}$ Autorizado pelo Ministério do Meio Ambiente (MMA) - Instituto Chico Mendes de Conservação da Biodiversidade (Icmcb), julho de 2008.
} 
Por outro lado, pode-se afirmar que o Nilo das Montanhas se assemelha ao rio brasileiro, pois, por força natural, rompe barreiras do planalto cristalino a partir do Lago Vitória, onde o Nilo é comparado a um grande sangradouro com destino ao Mediterrâneo, no norte da África.

Note que a referida fenda da estrutura rochosa, na chapada da Serra da Canastra, é perceptível no lado direito da imagem (fig. 05) anterior, em sua parte inferior, e a cachoeira está no lado esquerdo, onde se vê parte do corte da serra, por onde o Rio São Francisco flui. Observe que esse não é o ponto exato da nascente, mas, que se diga, um aspecto fenomenal da natureza, conforme anteriormente foi feito referência.

O curso fluvial ruma para o norte quando deixa para trás a Serra da Canastra, onde está a nascente, e segue entre a Serra Geral de Goiás, planaltos e chapadas da bacia do Parnaíba, à sua margem esquerda, a Serra do Espinhaço e a Chapada Diamantina, à direita.

A aproximadamente $8^{\circ} 31^{\prime} \mathrm{S}$, na região (Cabrobó/PE) de onde partirá um dos canais (eixo norte) da transposição, o rio passa a mudar de rumo, dirigindo-se para o leste, provavelmente por não ter podido romper a barreira do escudo cristalino do Nordeste. O Rio São Francisco está localizado em área cratônica que pertence ao período Pré-Cambriano (datando desde o Médio ao Inferior até o Médio ao Superior com 2 a 4,5 e 1 a 2 bilhões de anos, respectivamente), segundo Ross (2005). Estima-se que essa mudança de direção do rio aconteceu em razão de que a água passou a se deparar com aquela barreira acima citada, sendo obrigada a tomar outra direção e tal processo se deu ao longo do referido período geológico, pois "As plataformas ou crátons correspondem aos terrenos mais antigos e arrasados por muitas fases de erosão.” (ROSS, 2005, p. 48). Além disso, ainda de acordo com Ross (2005), os processos associados à movimentação (constante) das placas tectônicas e aos desgastes erosivos que foram produzidos por climas anteriores e atuais são os mecanismos genéticos do relevo brasileiro. Tudo isso vem corroborar a assertiva acima. 
Se o motivo da mudança de direção do curso fluvial não foi esse, é certo afirmar que tenha ocorrido de acordo com a análise de Ab'Sáber (1997, p. 2, grifo do autor):

Toda a complicação que obrigou o São Francisco pós-cretácico a encurvar-se para leste, a partir do Sobradinho e Morada Nova, deveu-se a irregularidades no levantamento das estruturas sedimentares dos fins do Mesozóico, distribuídas por espaços hoje situados no interior de Minas Gerais, Bahia, Pernambuco, Alagoas e Ceará. É quase certo que, por ocasião do exagerado levantamento que se fez atuar no centro da Bacia do Araripe, contribuindo para criar a grande mesa dos sertões de três Estados brasileiros, o curso do rio foi obrigado a desviar-se para leste, através de notável encurvamento, projetando-se para a faixa de fronteira dos atuais Estados de Alagoas e Sergipe. E, daí por diante, na medida em que a epirogênese fazia suas sucessivas saltações para o alto, o Rio São Francisco encaixava-se, mais e mais, até ao ponto de atingir o embasamento geológico regional, composto de gnaisses graníticos e migmatitos.

O São Francisco é o único grande rio brasileiro que deságua no Oceano Atlântico com nascente na mais alta latitude, entre as coordenadas geográficas $20^{\circ} 24^{\prime}$ de latitude Sul e $46^{\circ}$ 52' de longitude Oeste, de onde seu curso parte em direção à linha do Equador, e com maior proporção em relação ao seu ponto de partida e destino (no sentido norte).

Considerando as curvas de nível de acordo com o projeto Radambrasil, que foi desenvolvido pelo Departamento Nacional da Produção Mineral - Dnpm (1973) e o Ministério das Minas e Energia - MME (1981, 1982, 1983a, b), o alto curso do rio, conforme o mapa (fig. 06) a seguir, parte das cabeceiras (Serra da Canastra) com aproximadamente $1.350 \mathrm{~m}$ de altitude e vai diminuindo até a circunscrição do município de Pirapora/MG, onde é notável o afloramento de rochas no leito do rio, a jusante de onde começa a cota de $500 \mathrm{~m}$. A partir deste referido ponto fluvial, inicia-se o médio curso que termina na mudança de nível do relevo, na altura de uma cachoeira, no município Canindé de São Francisco/SE, conforme a descrição abaixo.

Dadas as condições físicas e naturais, e considerando os estudos a partir de projetos como o do Radambrasil, de acordo com o Dnpm (1973) e MME (1981, 1982, 1983a, b), e o EIA/Rima de Xingó segundo a Enge-Rio (1993b), denotou-se que a primeira dessas 
referências dá amparo à presente pesquisa sobre o perfil do relevo brasileiro e a segunda dá suporte sobre a existência de pontos testemunhos de cachoeiras ao longo do curso do rio.

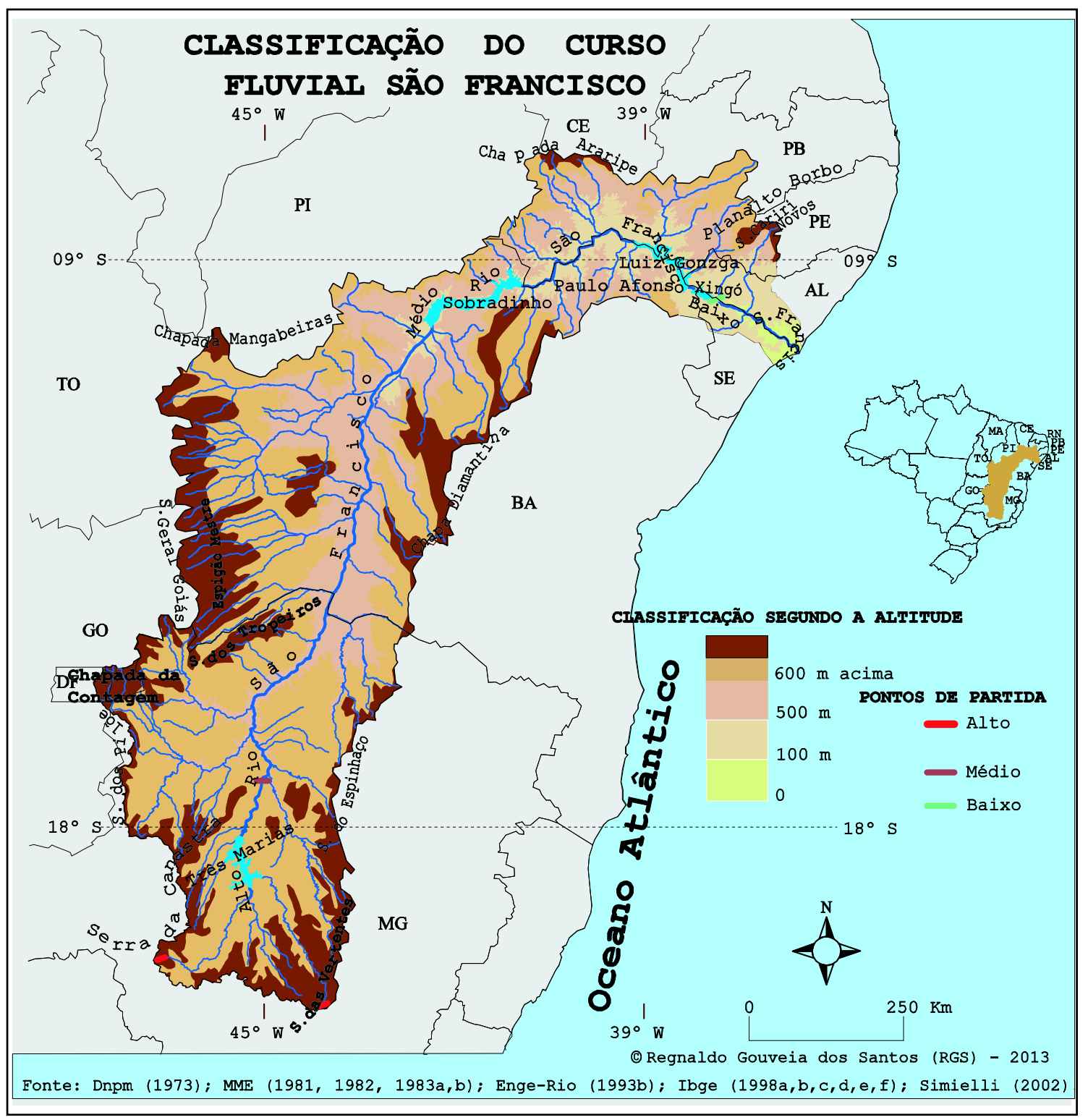

Figura 06. Mapa da classificação do curso do Rio São Francisco.

Desse modo, vale ressaltar que a classificação do curso do São Francisco, defendida no mapa (fig. 06), é válida pela sua relevância ao considerar que o baixo curso parte do último desnível do relevo, logo após o salto da Cachoeira dos Veados (atualmente inundada pelo lago da Barragem Xingó), cerca de $2 \mathrm{~km}$ a montante do paredão, findando na foz quando o rio se encontra com o mar, onde o curso fluvial atinge o nível zero. 
Com relação ao Rio Nilo, sabe-se que a sua nascente (a aproximadamente, entre as coordenadas geográficas $03^{\circ} 17^{\prime}$ Sul e $29^{\circ} 44^{\prime}$ Leste) localizada mais ao sul é a denominada Ruvyironza, que deságua no Rio Rurubu, e que parte da Região (ao sul) do Parque Nacional Kibira, na circunscrição da Colina Tshumba, próxima da sede do município Muramvya (Burundi). Tendo em vista que o Rurubu é contribuinte do Kagera e aflora perto do Lago Tangânica, na região da "Ruwenzori mountain range" (NICOL, 2003, p. 06), entre as correntes que deságuam no Lago Vitória, segundo Nicolau e Bellacasa (1905, p. 266) “[...] la principal de las cuales es el rio Kagera, que tiene su origen en las colinas Kangosi, á 2.000 metros de altura, con un recorrido hasta el lago de 600 kilómetros". Ou seja, percebe-se que referida nascente não aflora, exatamente, no pico de tal cordilheira que ultrapassa os $5.000 \mathrm{~m}$ de altitude.

O Rio Nilo está localizado na África, um continente marcado por aspectos geográficos importantes e que chamam a atenção até os dias de hoje. A heterogeneidade do seu espaço físico e natural, entre outros fatores, merece destaque. A situação geográfica do continente abrange os quatro hemisférios do planeta e a altitude do relevo atinge cerca de $6.000 \mathrm{~m}$ em áreas de pico como no Monte Quilimanjaro, no leste do continente, ligeiramente ao sul equatorial, e alcança 5.895 m, no Monte Quênia, na altura da linha do Equador, direção leste.

Em contrapartida a essas elevadas altitudes na região norte, a Depressão Quattarah registra 137 m abaixo do nível do mar. Essa é uma área que está no lado esquerdo do rio, próxima do Mar Mediterrâneo.

A partir de suas cabeceiras, depois do grande lago Vitória, o rio deixa a Cordilheira "Ruwenzori” para trás, na sua margem esquerda, e mais adiante, na margem direita fica o planalto da Etiópia, quando o Nilo Branco se encontra com o Nilo Azul. Após a junção das suas águas, o sinuoso curso fluvial passa a dar sinal de que o líquido essencial para os seres que habitam o deserto por onde o rio passa, está prestes a alcançar o baixo curso a partir da 
primeira catarata (região de Assuã) a jusante. Ao contrário do predominante rio de relevo observado no alto curso, localizado nas cabeceiras, a Região do Baixo Nilo é uma extensa depressão que mais se destaca dando forma às paisagens natural e cultural.

Cabe frisar que essa grande bacia hidrográfica não é constituída só por rios, mas também por lagos naturais que se concentram na região da cabeceira do rio, onde a estrutura do relevo apresenta forma mais irregular. No centro do grande planalto está o maior lago entre os outros que estão na mesma região, em geral separados por cordilheiras.

Os grandes lagos que se destacam no planalto equatorial são os seguintes: Vitória, Kyoga, George, Edward e Albert. Segundo Nicol (2003) as áreas de superfície desses lagos são, respectivamente, $67.000 \mathrm{~km}^{2}, 4.760 \mathrm{~km}^{2}, 300 \mathrm{~km}^{2}, 2.200 \mathrm{~km}^{2}$, e $5.300 \mathrm{~km}^{2}$. Em geral, não são registradas grandes profundidades nesses lagos. O lago Vitória, por exemplo, tem em média 42 m de profundidade, inferior à do Lago Albert, conforme o autor.

Ao analisar o mapa (fig. 07) a seguir, é possível observar algumas descrições citadas acima e, sobretudo, as referências em relação ao curso do rio.

O planalto da Etiópia também apresenta formas irregulares e tem a estrutura de seu relevo cristalino de origem geológica do período terciário como causa principal de tais características. A força natural das águas do Nilo Azul não agiu diferente do Nilo das Montanhas, pois rompeu barreiras do planalto tanto a montante, quanto a jusante do Lago Tana, formando, entre outras cataratas, a Tissisat, ainda no planalto. Ao notar as rochas que afloram no leito do rio, é possível ter noção da tamanha força fluvial.

Por fim, em Cartum, que está antes da $6^{\text {a }}$ Catarata representada no mapa (fig. 07) a seguir, o Nilo Azul se encontra com o Nilo Branco para os dois formarem o extenso Rio Nilo, com cerca de $3.000 \mathrm{~m}^{3} / \mathrm{s}$ de vazão; toda a sua bacia hidrográfica corresponde a cerca de $10 \%$ de todo o continente africano. Nesse sentido, de acordo com Diarra (2010, p. 360): “Apesar de sua grande extensão, sem igual na África $(6.700 \mathrm{~km})$, o Nilo é pouco volumoso, 
possuindo um débito médio anual inferior a $3.000 \mathrm{~m}^{3} / \mathrm{s}$. Porém, tem sido desde a Antiguidade, um dos rios mais úteis do mundo".

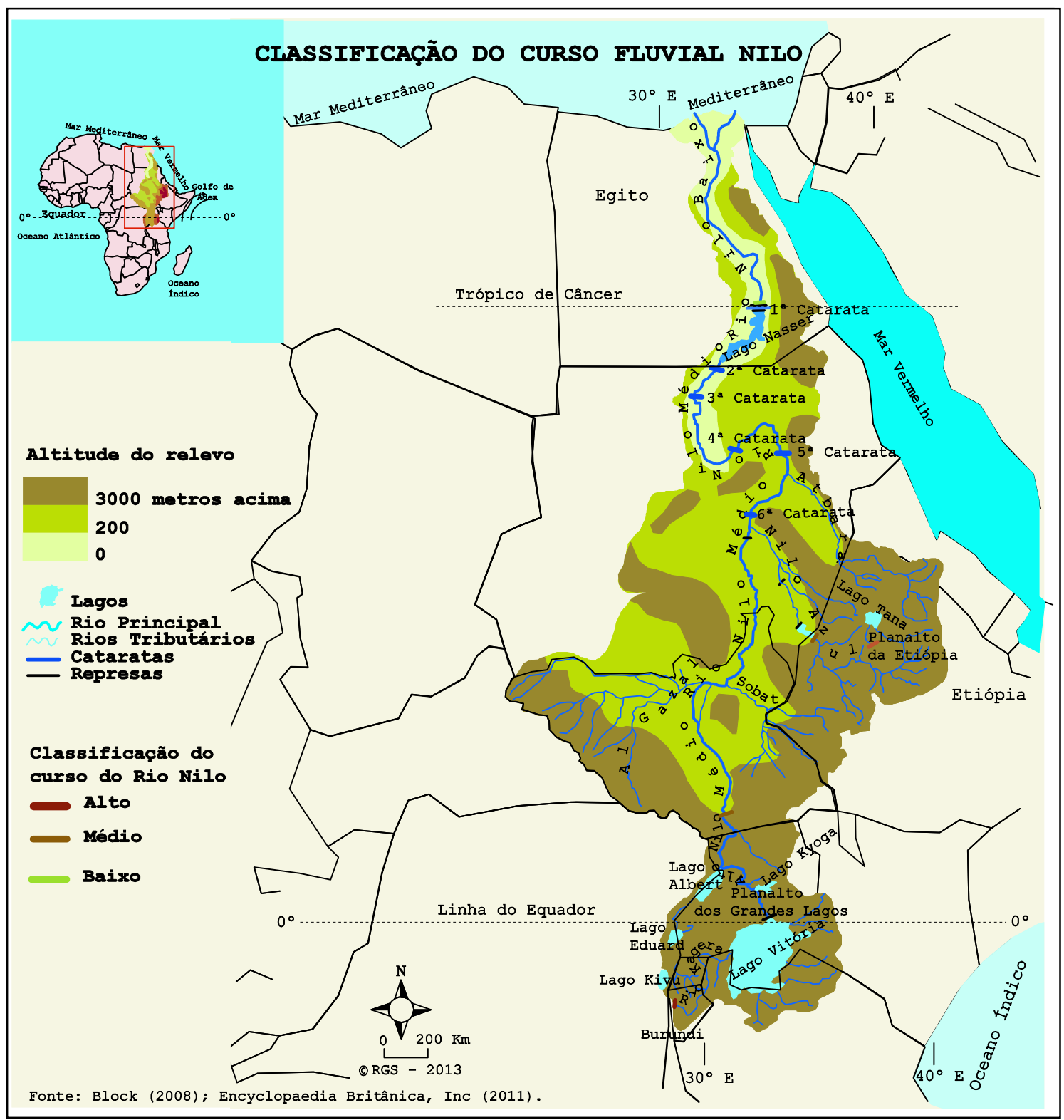

Figura 07. Classificação do curso do Rio Nilo.

Corrobora com as assertivas acima, o que bem observou Scalzaretto (1995, p. 248) ao afirmar sobre o relevo africano:

[...] com predomínio de terrenos de formação geológica antiga. Já bastante desgastados pela erosão, esses terrenos correspondem aos extensos planaltos cristalinos, que ocupam a maior parte do continente. São intercalados por algumas bacias sedimentares de origem mais recente, que se localizam em alguns planaltos de baixas altitudes e nas raras planícies africanas. Os 
poucos trechos mais elevados são compostos de montanhas do período terciário, [...].

Isso ratifica a existência das poucas montanhas, porém, bastante altas, encontradas ao longo de toda a bacia hidrográfica do Rio Nilo, conforme já foram dadas suas referências, anteriormente, entre montes e cordilheira.

A bacia hidrográfica do Rio Nilo é uma das maiores e das que mais chamam a atenção no mundo em termos de aspectos naturais (clima e vegetação), pois abrange uma extensa área com cerca de três milhões de quilômetros quadrados. Ao longo desse espaço geográfico, tais aspectos se apresentam bastante heterogêneos, quer sejam por razão da forma do relevo, quer sejam pela diferença de clima por onde o curso do rio passa. Esses fatores são causa da grande variedade do porte da vegetação encontrada em toda a bacia hidrográfica.

Assim, da análise da paisagem natural, foi possível notar que alguns aspectos semelhantes observados em relação aos elementos do espaço geográfico desses dois rios, assim como a direção percorrida pelos leitos que tomam o norte como rumo, chamam a atenção de qualquer observador mediante os elementos comuns já citados. Ao comparar a distância percorrida de seus leitos, a maior proporção está no sentido norte, apesar da direção do Rio São Francisco tomar o sentido leste na altura do médio e do baixo curso, cerca de 400 $\mathrm{km}$ da foz.

O fato de esse rio possuir curso contínuo a partir da sua mais elevada latitude (nascente) e por envolver os vários Estados que abrangem sua bacia hidrográfica, principalmente, por ter sua extensão genuinamente brasileira até desaguar, pesa, sobretudo, o seu sentido de Rio da Integração Nacional. Já o Rio Nilo, por ter sua particularidade com nascente no sul e foz no norte da linha do Equador, e com maior extensão entre todos os rios em tal condição, além de banhar os vários países de sua bacia hidrográfica, é um Rio de Integração Continental. 
Dada a equiparação das coordenadas geográficas dos rios, é possível perceber que as características naturais, assim como a forma do relevo, também são uma condicionante do clima em função da dinâmica da circulação das massas de ar.

Suas nascentes situam-se em pontos com elevadas altitudes, sendo que o rio brasileiro ultrapassa os $1.350 \mathrm{~m}$ do nível do mar, apesar dessa cota ser inferior à do Nilo com cerca de $1.770 \mathrm{~m}$. As vazões de seus cursos d'água têm expressivas semelhanças, pois na primeira década deste século, em ambos os rios, já se registravam médias de pouco menos de 3.000 m³/s. Assim, não restam dúvidas de que tiveram volumes semelhantes no passado, pois ambos os rios manifestaram força natural, por romperem barreiras dos relevos de suas bacias hidrográficas, conforme já foi afirmado.

Entre outros fatores, ressalta-se a situação geográfica dos grandes caudais que perfazem cursos distintos, o primeiro teve de ultrapassar a linha do Equador, seguindo para a região norte, enquanto o segundo está todo no hemisfério Sul. Suas semelhanças naturais, sejam em relação aos climas, às formas do relevo, ou aos biomas observados ao longo de suas bacias hidrográficas, podem colaborar com interpretações sobre os aspectos físicos e naturais, o que é relevante para a sociedade que tanto tem buscado respostas sobre a ação da natureza. Daí por que tal diferença entre os rios chama a atenção, visto que essa não foi capaz de impedir a existência dos elementos semelhantes em referidos espaços geográficos.

Algumas sub-regiões desses espaços apresentam aspectos semelhantes, tanto que há áreas de bioma e clima semiáridos nos dois, além de um clima semelhante predominar nas suas cabeceiras, isto é, quente e úmido. Depois de deixarem as nascentes para trás, os cursos dos rios fluem em grandes depressões até alcançarem suas fozes, sendo a do Nilo em delta, e a do São Francisco, em estuário, conforme já citados. Por fim, notou-se que seus ciclos de cheias naturais eram muito semelhantes, ou seja, alagavam suas várzeas em tempos certos 
anualmente, porém, algumas vezes de forma natural, sofriam alterações no volume das cheias, fato observado, particularmente, nos seus baixos cursos.

O período sazonal e cíclico de cheias dessas duas bacias hidrográficas, enquanto durou, representou um fato que chama bastante atenção e que é relevante por ter sido responsável pelos seus aspectos naturais. Neste caso, à medida que no Rio Nilo acontecia o ciclo anual das cheias, com início em agosto e o seu final em março, foi possível perceber que o começo desse fenômeno se antecedia três meses em relação ao do Rio São Francisco, que tinha suas várzeas inundadas a partir de novembro, mas com o recuo das águas também em março, assim como acontecia no rio africano. A diferença acima destacada pode ter relação com a extensão dos cursos fluviais, de modo que o ciclo de cheias do Nilo durava mais tempo por ter uma bacia hidrográfica maior, como também uma área de planície mais extensa do que a do rio brasileiro. Entre outros fatores responsáveis por tal diferença, aduzem-se às condições climáticas, à geomorfologia, às situações geográficas dos rios contribuintes.

\subsection{A RELAÇÃO RELEVO, CLIMA E VEGETAÇÃO}

A presente abordagem contempla a paisagem natural com foco na bacia hidrográfica do Rio São Francisco, revelando alguns aspectos do Rio Nilo em comparação com outros do rio brasileiro.

Pode-se dizer que o relevo brasileiro tem participação significativa sobre os aspectos climáticos ao longo da depressão da bacia hidrográfica do Rio São Francisco, principalmente a Serra do Espinhaço (Minas Gerais), a Chapada Diamantina (Bahia) e, em menor grau, o planalto da Borborema, que atinge as mais elevadas altitudes entre Pernambuco e Paraíba. Isso se deve ao fato de a Bacia Sãofranciscana estar num espaço de depressão a sotavento, à 
medida que sofre a ação de várias correntes atmosféricas que transpõem todo esse relevo de elevadas altitudes, circunscrevendo o curso fluvial.

Assim, as massas de ar de origem oceânica que convergem para essa região, até atingir as margens do rio têm de ultrapassar, primeiramente, tal barreira. Fato que muitas vezes faz a precipitação pluvial ser muito inferior na Depressão Sãofranciscana em relação ao topo ou às áreas a barlavento de seus divisores de água. Tais áreas são as frentes das serras ou montanhas que recebem as massas de ar úmidas e que começam, portanto, a se precipitar no momento em que alcançam o relevo, atingindo os topos igualmente ou mais acentuadamente. A chuva orográfica ocorre desse modo, mas à medida que transpõe as barreiras, sua intensidade vai diminuindo.

Da análise da pesquisa e de acordo com o mapa (fig. 08) a seguir, observa-se que um dos fatores a justificar o grande caudal é, certamente, a grande estrutura de relevo seguindo essa depressão, além das massas de ar que atingem tal estrutura. Ao alcançarem esta estrutura, no verão, as massas Tropical atlântica (formada no Oceano Atlântico), Equatorial continental (formada no continente, a partir da floresta amazônica) e Equatorial atlântica (no Oceano Atlântico) deságuam boa parte de sua carga de umidade. Só depois de bem menos úmidas, atingem a área de depressão com menor intensidade em relação aos divisores de água, nos quais ocorrem as precipitações mais intensas no mesmo período.

A temporada das chuvas mais intensas é, portanto, marcada pelas grandes cheias do Rio São Francisco. É principalmente a partir de suas cabeceiras e de seus afluentes dos divisores colaterais que, se constitui a multiplicação das águas que já engendrou uma vazão de 13.000 m³/s, de acordo com Andrade (2004), na foz. Fato semelhante acontece com o Rio Nilo, isto é, todo o vigor que o rio tem para atravessar o Deserto Saara se deve à soma do volume d'água recebido, sobretudo, a partir de suas cabeceiras, onde predominam climas propícios à precipitação, desde o Planalto dos Grandes Lagos até o da Etiópia. 


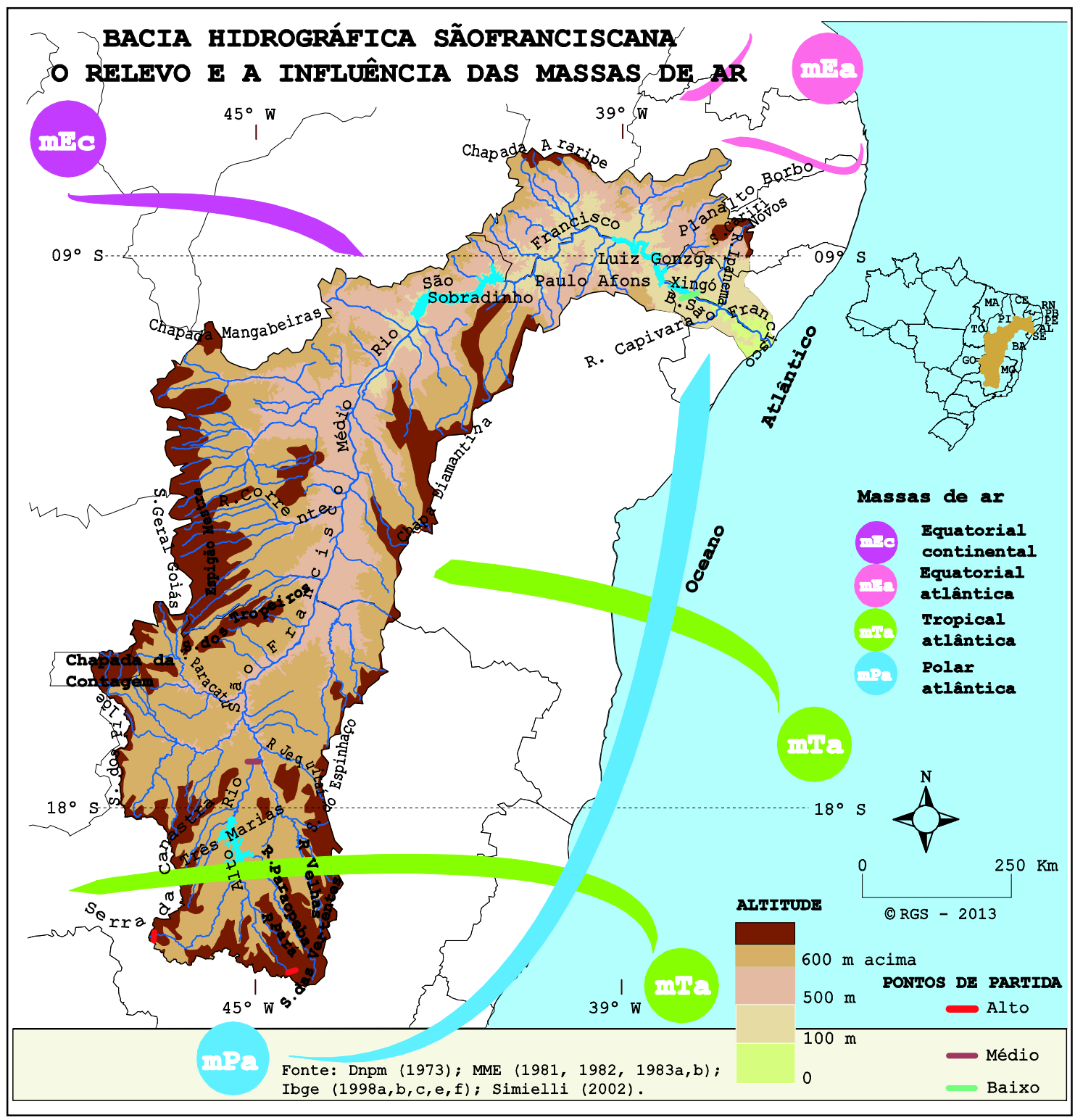

Figura 08. Mapa da Bacia Hidrográfica São Francisco - relevo e influência das massas de ar.

A massa Tropical atlântica expande-se com maior intensidade e força sobre a Bacia Hidrográfica Sãofranciscana no inverno, o que normalmente, vem acarretar importantes chuvas na depressão da sua extensão mais ao nordeste, desde a Bahia até Sergipe e Alagoas, o oposto da estação de verão. A presença da massa Polar atlântica, ocasionalmente, atinge o Nordeste através de sua expansão pela fachada Sul-Oriental do Brasil, chegando a se misturar com a Tropical atlântica. Aquela massa de ar, por vezes, pode ser sentida durante a estação de inverno graças à sensação de frio em pontos relativamente mais altos de alguns lugares da 
Depressão Sãofranciscana, desde a Bahia até Sergipe, na faixa sertaneja. Na referida estação, essas duas massas de ar predominam atuando sobre referida área.

Quando a massa Polar atlântica avança pelo interior do Brasil, encontra a barreira do relevo brasileiro, o que a impede de se expandir de maneira uniforme sobre a Depressão Sãofranciscana. Isso faz com que nessa região, as chuvas que ocorrem do sul ao norte de Minas diminuam significativamente no inverno, o contrário do que ocorre no verão, ou seja, chove mais nesta estação e menos naquela. Um dos principais fatores que podem justificar as chuvas de verão nessa região mineira é a influência de duas massas de ar com origens distintas, a saber: a massa Equatorial continental, vinda do noroeste (em relação a Minas Gerais), oriunda da Amazônia e a massa Tropical atlântica, vinda da sub-região Sul-Sudeste, formada no Oceano Atlântico. Essas massas são quentes e úmidas também por razões distintas; a primeira, apesar de se formar no continente, é úmida porque a formação das condições hídricas e vegetais da floresta amazônica contribui com isso; e a segunda é úmida porque se origina sobre o Atlântico. As chuvas dependem também da oscilação da Zona de Convergência Intertropical (Zcit) e da Zona de Convergência do Atlântico Sul (Zcas).

Esses processos climáticos formam, pois, fatores importantes e marcantes do conjunto de climas identificados em toda a bacia hidrográfica do Rio São Francisco, representados no mapa (fig. 09) a seguir. A partir da Região Sudeste, de onde as águas desse rio afloram predomina, no Brasil, o clima Tropical alternadamente úmido e seco. Isto é, está entre os trópicos de Capricórnio (próximo da nascente do rio) e Câncer (ao norte da Linha do Equador), além do clima se caracterizar como típico por ser chuvoso no verão e seco no inverno. Também classificado como subúmido, sua média pluviométrica varia de $1500 \mathrm{~mm}$ a $750 \mathrm{~mm}$ anuais. 


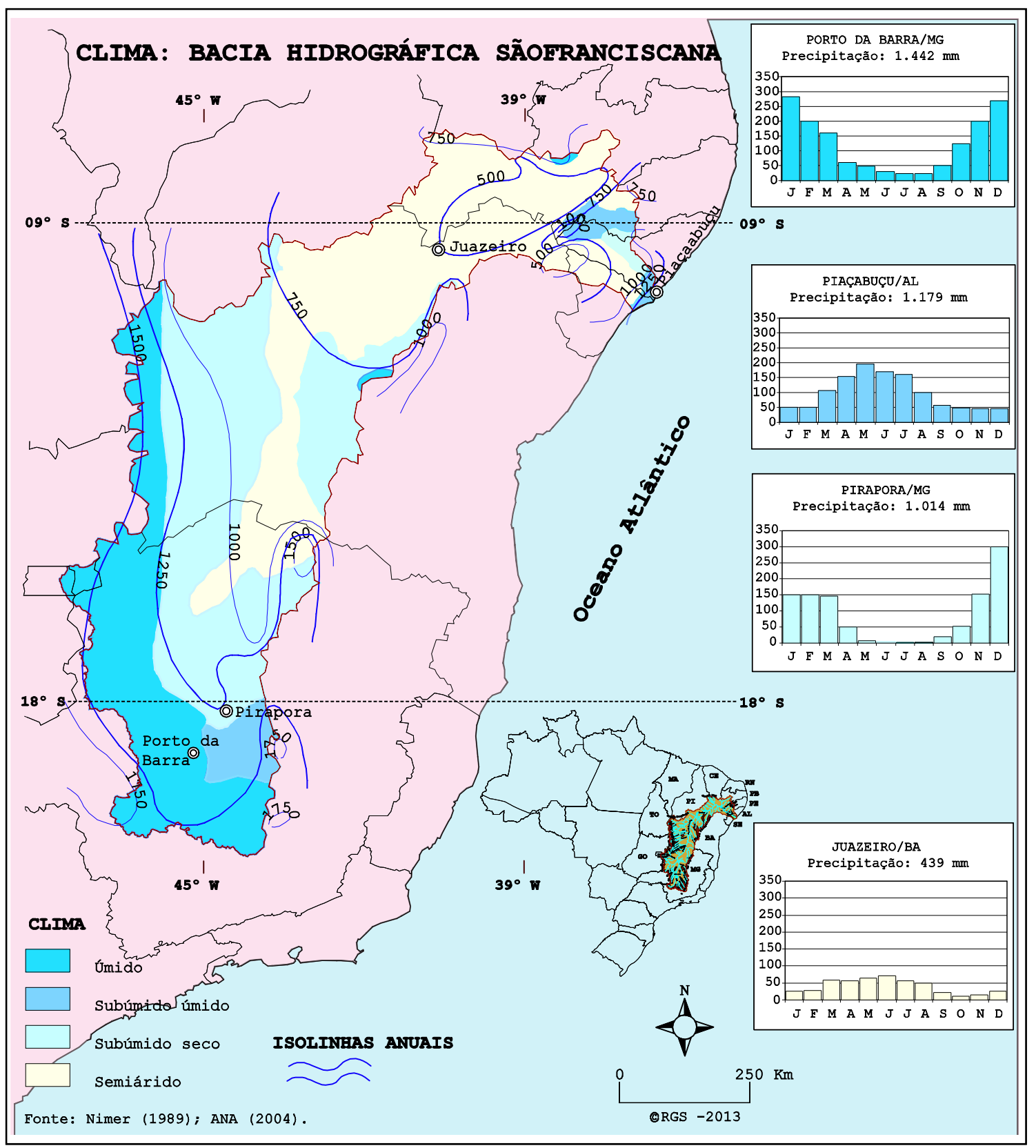

Figura 09. Mapa do clima da Bacia Hidrográfica São Francisco.

Nesse contexto, os contrastes sazonais em relação aos fatores climáticos que se apresentam entre as regiões Sudeste e Nordeste do Brasil, abrangidas pela Bacia São Francisco chamam a atenção. Percebeu-se que, enquanto os Estados nordestinos banhados pelo rio têm as chuvas, normalmente, mais distribuídas e prolongadas na estação de inverno, boa parcela de Minas Gerais (Região Sudeste) sofre com as estiagens devido às condições climáticas, características desse período sazonal desta região. Essa pode ser uma das razões de 
se referir ao Brasil como país continental, pois é sabido que quando na porção austral do Mundo está inverno, no Norte acontece o oposto (o verão). Isso significa dizer que a Bacia São Francisco é tão extensa e se encontra em tal disposição que é possível apresentar tais características aludidas acima.

No sertão do nordeste brasileiro, em comparação com o caso do Rio Nilo, o São Francisco atravessa uma extensa área de clima semiárido tendendo a seco porque é atingido de maneira irregular pelas massas de ar, tanto que, de acordo com Conti (2011, p. 57), "Em latitudes tropicais, admite-se que as médias pluviométricas anuais entre $750 \mathrm{~mm}$ e $250 \mathrm{~mm}$ constituem os valores limites das regiões semiáridas". Por fim, o rio deságua no litoral atlântico onde se caracteriza o clima litorâneo úmido, que está exposto às massas tropicais marítimas.

A porção da bacia hidrográfica que apresenta o clima semiárido é a que mais chama a atenção, haja vista os impactos desencadeados ao longo do baixo curso do São Francisco, segundo Santos (2010). Na região que apresenta esse clima, estão instaladas as mais importantes hidrelétricas do Nordeste, ora em atividade, usando a água das barragens construídas no curso do rio. Nessa região situa-se o Lago Sobradinho, um dos maiores do mundo, logo à jusante há várias outras barragens com reservatórios de menor porte como a Luiz Gonzaga, Complexo de Paulo Afonso I, II, III e IV, Moxotó e Xingó. Além de tudo, outro agravante está se confirmando para a redução do volume do caudaloso rio: a transposição de suas águas para outras bacias hidrográficas, fator questionável sob vários pontos de vista, pois que há outros meios viáveis para dessedentação humana e animal. É por essa e outras razões que o presente estudo enfatizará a seguir a referida região, nessa ordem de ideias.

Na abrangência de tal espaço, existem vários municípios banhados pelo São Francisco, mas atingidos por secas longas e severas, características desse clima, desde o norte de Minas 
Gerais até os Estados da Bahia, Pernambuco, Alagoas e Sergipe. Como se não bastassem as consequências climáticas, não há planejamento, investimento ou iniciativas públicas eficientes e efetivas que visem combater a sede, a fome, entre outros aspectos socioeconômicos, que afetam o povo nessa região. Sabe-se que os alísios de nordeste chegam a influenciar o clima desse espaço geográfico ao se encontrarem com a predominante massa Tropical atlântica. No entanto, esse fenômeno não se apresenta de maneira intensa nessa área, visto que se acentua de forma marcante na porção setentrional.

Os alísios de nordeste são ventos que sopram do trópico de Câncer em direção à linha do Equador, mas por forças do movimento de rotação da Terra se desviam para o Leste, atingindo a referida região. A situação no Baixo São Francisco se agrava com o El Niño, um fenômeno natural, conhecido por alterar as condições do clima onde ocorre, com períodos aproximados de duração que vão de dois, cinco ou até sete anos, atingindo desde a linha equatorial até o litoral do Peru, elevando as temperaturas das águas superficiais do Pacífico. Nessa concepção, de acordo com Conti (2011, p. 40):

As secas de grande expressão espacial são fenômenos não controláveis pelo homem e dependem de fatores de macroescala, inclusive das relações atmosfera-oceano. Nas baixas latitudes, a ocorrência de estiagens pode estar associada à oscilação da Zona de Convergência Intertropical (ZCIT). [...] No Brasil, parece ser, em certos anos, o caso do Nordeste, onde também há a influência do fenômeno El Niño.

O Brasil, país da América do Sul com pouco mais de 8,5 milhões de quilômetros quadrados, apresenta muitas formações vegetais dentre as quais se destaca a floresta amazônica, por sua grande extensão e rica biodiversidade. Entretanto, as formações vegetais a serem destacadas, neste caso, não são as que constituem a Amazônia brasileira, mas as predominantes da bacia hidrográfica do Rio São Francisco.

Como o clima é um fator que influencia diretamente no tipo de vegetação, as formações vegetais apresentadas no conjunto da Bacia São Francisco estão em sintonia com as condições climáticas ali existentes. 
De acordo com Ab’Sáber (2003), os domínios morfoclimáticos presentes na Bacia Sãofranciscana são cerrados, caatinga e mares de morros. É importante ressaltar que em toda sua extensão, é possível verificar a existência de enclaves, porções de biomassas vegetais encravadas em áreas de domínios vegetais totalmente diferentes daquelas. Ainda na circunscrição da Serra da Canastra, logo que a cortina d'água da Cachoeira Casca d'Anta atinge o sopé da serra, se formam corredeiras que banham um tipo de vegetação densa e característica de mata atlântica. No topo da serra, em toda a chapada, estende-se uma vegetação típica de cerrado, plantas de baixo porte, galhos bastante retorcidos e com casca grossa, além de raízes profundas; há também uma vegetação herbácea, característica de campo e que, em época de estiagem, é percebida uma extensa área dourada do capim nativo. Da análise da pesquisa, percebe-se que as características fitogeográficas observadas são semelhantes às da nascente do Rio Nilo.

É possível afirmar que esses aspectos de cerrado, observados na chapada da Serra da Canastra, se resumam ao que foi classificado, segundo Conti e Furlan (2005), como campo sujo em áreas de Ecótonos. Um dos fatores da ocorrência dos Ecótonos são as ações das queimadas, que muitas vezes arrasaram a referida chapada, de forma indesejada.

Na bacia hidrográfica do Rio São Francisco, na altura de seu alto curso predominam as florestas-galerias que correspondem, de acordo com Ab'Sáber (2003, p. 18, grifo do autor): "Posição geral da área: grosso modo zonal, à semelhança do que ocorre com o vasto domínio das savanas na África”.

No Estado de Minas Gerais, ao longo da Bacia Sãofranciscana, é possível notar pequenos nichos de mata atlântica. Esses resquícios existem, entre outros motivos, porque foram criadas áreas de Reservas Particulares do Patrimônio Natural (Rppn), constituídas como unidades de conservação, observadas no mapa (fig. 10) a seguir. O fator principal que engendra esses nichos ecossistêmicos é o que bem observaram Conti e Furlan (2005, p. 172): 
O mecanismo de distribuição da umidade da Massa Polar Atlântica é o responsável pela exuberância e diversidade dessas florestas. Os ventos carregados de umidade são barrados por diversos acidentes orográficos na zona costeira, descarregando grandes volumes de água. As regiões de maior pluviosidade do Brasil encontram-se em sua região Sudeste.

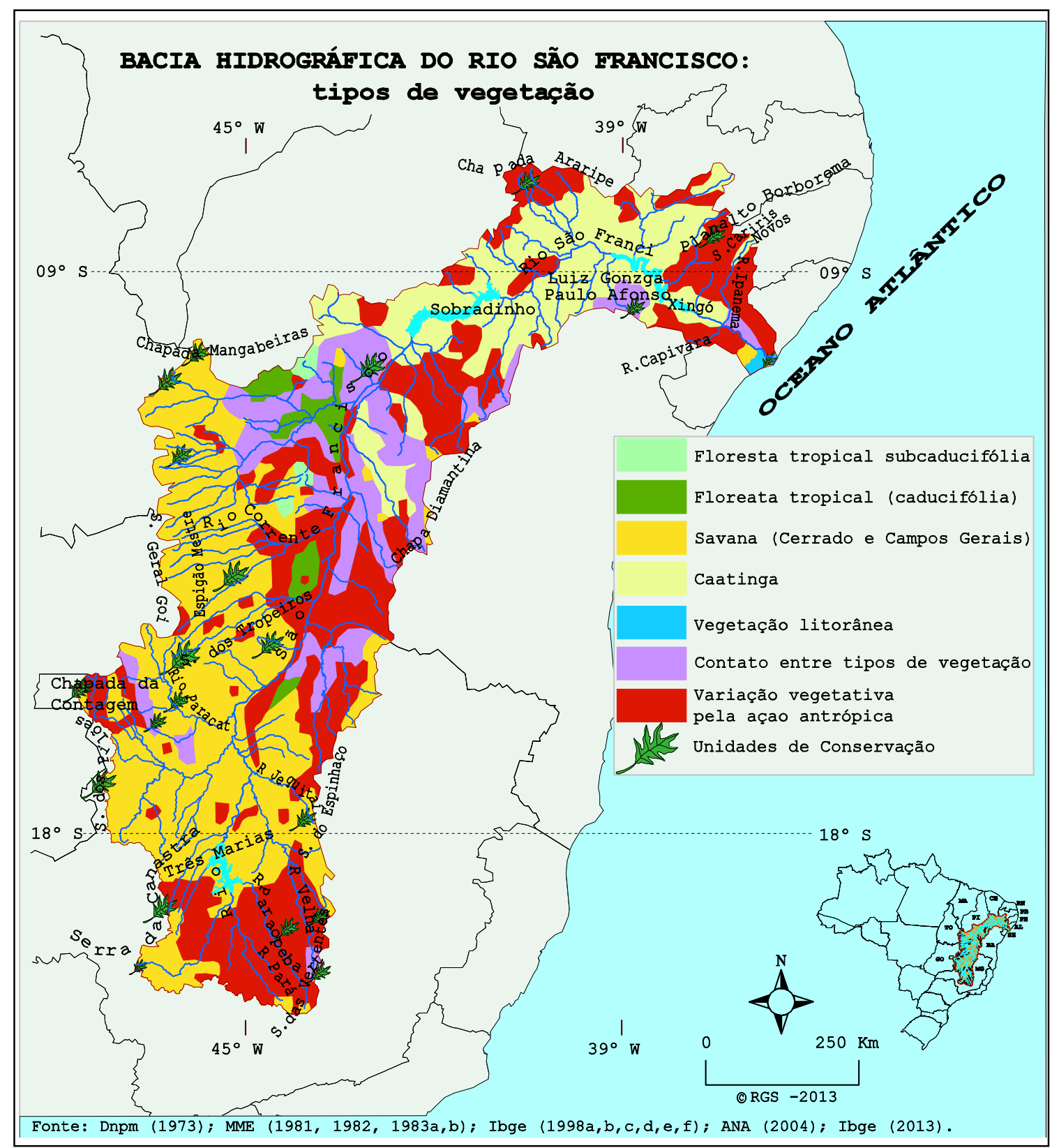

Figura 10. Mapa da Bacia Hidrográfica São Francisco - Vegetação.

O clima subúmido predomina nessa parte da bacia hidrográfica; regra geral, sua formação vegetal cerradão se apresenta com características que chega a se confundir com a 
savana do Alto Nilo, onde o clima apresenta índices pluviométricos consideráveis, ao longo do ano.

Já no sertão, a caatinga representada no mapa (fig. 10) anterior predomina em todo o espaço por entre as colinas, serras, grotas e depressões na sua grande maioria e, por vezes, circunda os pingurutos (apresentam semelhanças de local alcantilado), estes geralmente sem vegetação densa devido ao solo raso que expõe muitos fragmentos de rocha. Por atingirem pontos altos e sua extensão se acabar, geralmente em forma de despenhadeiro, os pingurutos oferecem muito perigo a animais de grande porte que se deparam com esses pontos quando menos esperam. Além disso, nessa região, como em várias outras partes da Bacia São Francisco, há uma variação vegetativa devido à ação antrópica sobre o referido bioma. Apesar de tudo, o espaço sertanejo também apresenta algumas exceções em relação ao tipo de vegetação, ora essas exceções são observadas nas partes que sofrem o efeito orográfico, ora nas margens do rio ocupadas pela mata ciliar, entre outras circunstâncias, como se pode detectar a vegetação original, no Raso da Catarina.

Ratificam-se as assertivas acima, de acordo com o que bem observou Ab'Sáber (2006b, p. 94, grifo nosso):

O 'Raso da Catarina' é uma exceção, comparado com esses casos habituais. Trata-se de uma verdadeira baixa chapada arenítica, colocada ao norte da Bahia, entre o São Francisco e o Vasa Barris, e ladeada por dois vales de direção sul-norte: o Macururé e o Xingoziho. Essa baixa chapada recoberta extensivamente por caatingas primárias tem aproximadamente $70 \mathrm{Km}$ de eixo menor (oeste-leste) e $80 \mathrm{Km}$ de eixo maior (sul-norte). Possui pouco mais de 400 metros de altitude, evidenciando porém uma discreta ascensão de noroeste para sudeste, desde a aldeia de São Francisco até os arredores de Jeremoabo.

De acordo com o que se constata ao analisar o mapa (fig. 10) anterior que representa os tipos de vegetação, nem sempre a mata ciliar está presente nas margens do rio devido à ação antrópica que, entre outros fatores, tem sido a causa da alteração desse espaço ao longo da história fluvial do São Francisco. A catingueira (comum na região) chega a ultrapassar, naturalmente, os quatro metros de altura na fase adulta, com galhos tortuosos espalhados, 
sombreando, às vezes, uma área diametral com mais de três metros, sua vagem parece a do pau-brasil e seu caule é bastante forte. Os mandacarus, xiquexiques e facheiros são da família cactácea e contêm espinhos; os juazeiros, imbuzeiros e avelóses (também conhecidos por populares da região como labirintos), normalmente apresentam-se verdes em período de estiagem. Os dois primeiros destes três últimos destacam-se com suas folhagens verdes de tal maneira que realçam através da caatinga cinzenta. Observou-se que isso é possível porque as raízes dos juazeiros atingem o solo profundamente, em busca de água existente no subsolo, por exemplo, e os imbuzeiros possuem raízes em forma de cabaça ou de batata ("fufu de imbu", segundo moradores da região). Neste caso, cabe frisar que enquanto as soltas (terras devolutas) do sertão existiram, os vaqueiros matavam a sede com essas raízes ao se perderem pela caatinga adentro, a procura do gado que ficava solto para pastar um longo período que perdurava por meses.

Essas raízes de imbuzeiros têm uma característica natural de absorver a água no período chuvoso e a capacidade de preservá-la para se manter durante a estiagem ao longo do ano. Esta é uma das razões que justificam o fato dessa vegetação se manter com folhagem verde, depois de período chuvoso, enquanto que os avelóses se mantêm sempre verdes independentemente do período de inverno ou verão, possivelmente por causa de um líquido branco existente entre seu lenho e a casca. Essas espécies são notáveis na paisagem de áreas que ainda não foram totalmente degradadas ao longo do sertão banhado pelo Rio São Francisco. Na época de estiagem, esse espaço apresenta uma cor cinzenta na paisagem natural por causa da ausência das folhas das catingueiras, predominantes no bioma Caatinga.

A capacidade de regeneração da exuberância da biomassa desse bioma é algo extraordinário. É ver para crer, pois o fenômeno da natureza é testemunhado por todos que habitam esse espaço. Basta uma trovoada de época na região que em cerca de uma semana a exuberante biomassa vegetal se estampa através das folhas das catingueiras, principalmente. 
Por vezes, isso foi observado no Sertão Sãofranciscano do Estado de Sergipe, em finais de ano, de maneira que, geralmente, se ouviam falas populares dessa região: - as árvores estão se vestindo para Natal e Ano Novo. Assim é o sertão, pois quando chove, de acordo com Cunha (2000, p. 53):

[...] reverdecem os angicos; lourejam os juás em moitas; e as baraúnas de flores em cachos, e os araticuns à ourela dos banhados... mas, destacando-se, esparsos pelas chapadas, ou no bolear dos cerros, os umbuzeiros, estrelando flores alvíssimas, abrolhando em folhas, que passam em fugitivos cambiantes de um verde pálido ao róseo vivo dos rebentos novos, atraem melhor o olhar, são a nota mais feliz do cenário deslumbrante.

E o sertão é um paraíso...

No caso da bacia hidrográfica do Rio Nilo, por ser de grande extensão, na proporção em que abrange a região do Equador e o trópico de Câncer, além de ultrapassar este ao norte, é o fator das baixas latitudes que mais se destaca na caracterização climática, conforme a abordagem a seguir e a análise do mapa (fig. 11) adiante.

Assim como a estrutura do relevo, o clima presente na bacia hidrográfica do Rio Nilo não é tão simples porque, além das baixas latitudes, outros fatores naturais o influenciam, como correntes marítimas e os ventos alísios que sopram na direção equatorial.

Ao comparar os mapas das figuras 11 e 12 que seguem, é possível observar que desde o Planalto dos Grandes Lagos até o da Etiópia, predominam os climas tropical e tropical de altitude, respectivamente, fatores naturais que agraciam essa sub-região da bacia com condições de significativa distribuição de chuvas. O clima que corresponde a melhor distribuição e expressivos índices de chuva ao longo do ano, o Equatorial, é notável, neste caso, ligeiramente ao norte da linha do Equador, mas dentro desta zona climática, na qual, consequentemente, a vegetação mais exuberante se apresenta.

Mediante as diferentes formas de relevo observadas no próximo mapa (fig. 12) e em função das variadas massas de ar marítimas e continentais que afetam a região, o clima não poderia ser homogêneo, o qual varia bastante a partir da linha do Equador (vide mapa (fig. 
11)), de modo que as médias pluviométricas diminuem tanto na direção centro-norte, com maior expressão (destaque para o Deserto Saara), quanto no sentido centro-sul da África.

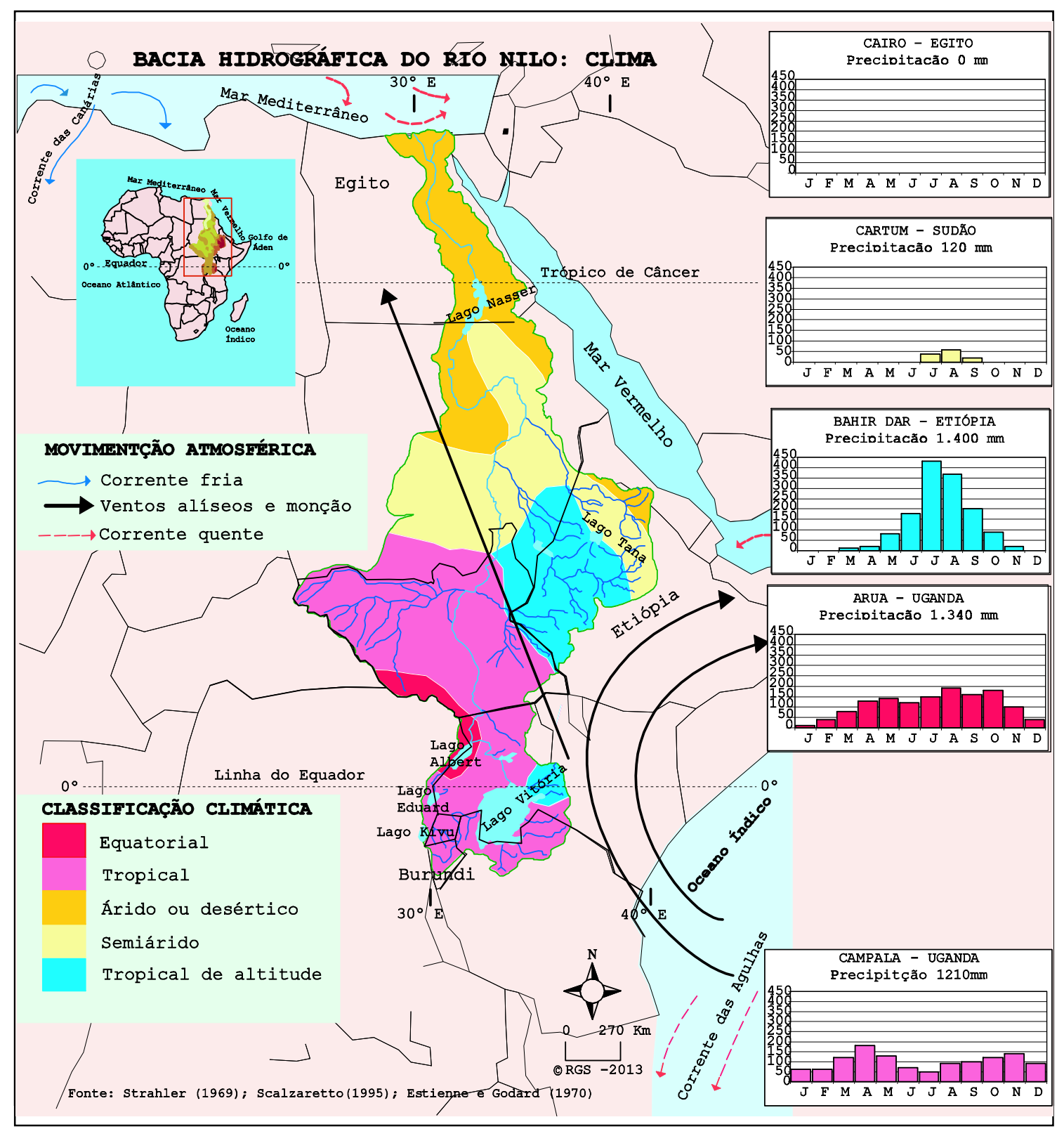

Figura 11. Mapa da Bacia Hidrográfica do Nilo - Clima.

A nascente do Rio Nilo está ao sul da linha equatorial, mas bem próxima desta, numa área em que o clima tropical predomina, proporcionando a existência da exuberante savana.

Já a nascente do Nilo Azul, formadora do Rio Nilo, está ao norte da linha do Equador, em zona de clima tropical de altitude, e devido ao fato de se localizar no planalto da Etiópia, com elevadas altitudes, é a vegetação de altitude que predomina na região. 


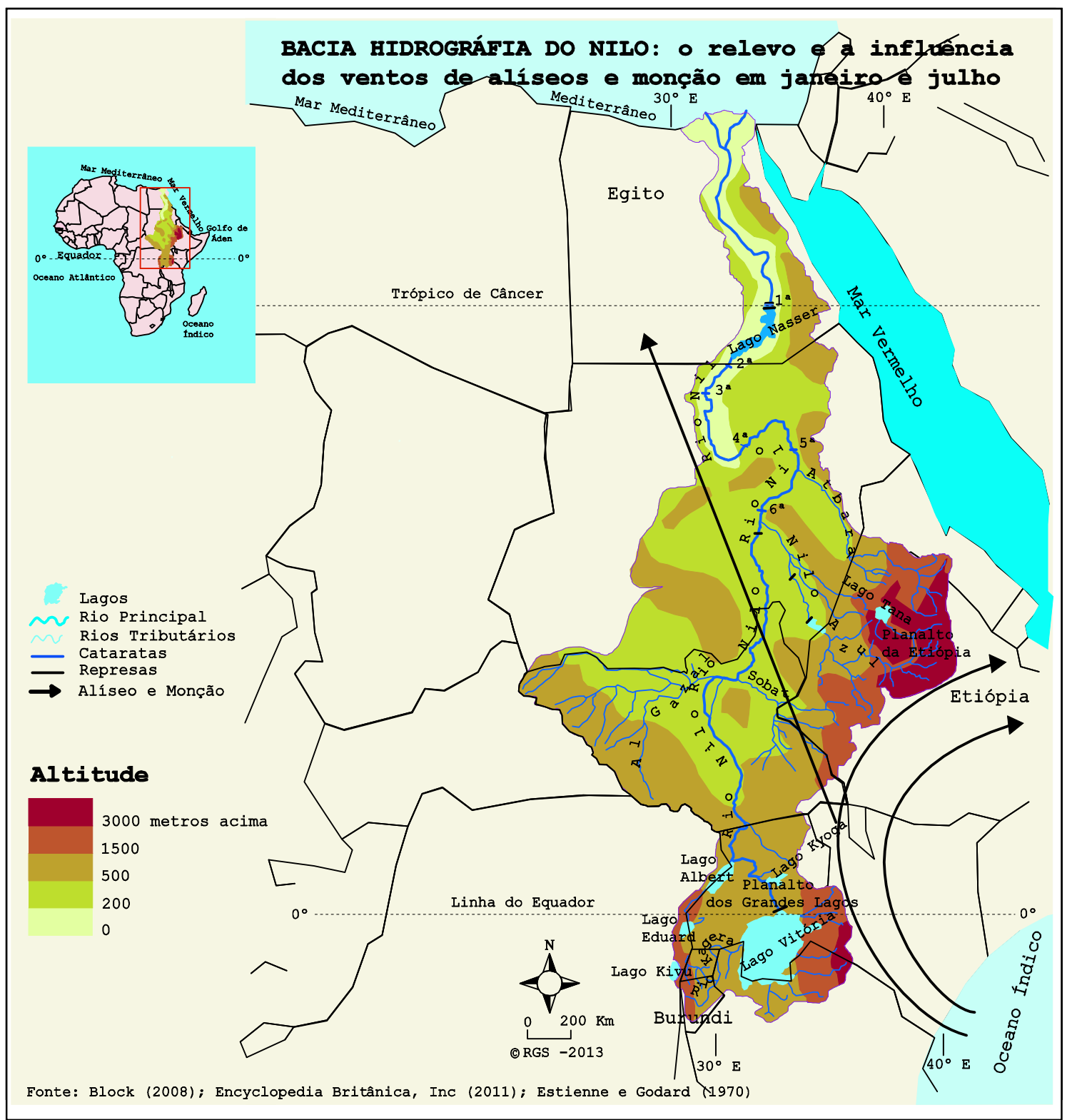

Figura 12. Mapa da Bacia Hidrográfica do Nilo - Relevo.

As características do clima identificado na região etíope são responsáveis por importantes chuvas que ocorrem de junho a novembro. O fenômeno, a monção de verão, acontece graças à influência do movimento da Zona de Convergência Intertropical (Zcit). Entre os principais fatores que contribuem com a ocorrência do fenômeno estão os aspectos físicos do relevo e sua localização, ou seja, as elevadas altitudes e a proximidade da costa do Mar Vermelho, respectivamente. 
Nessa concepção, como bem observou Conti (2011, p. 40): “Quando se desloca exageradamente para o norte ou para o sul do equador, a ZCIT faz diminuir de forma significativa as chuvas na região subequatorial do respectivo hemisfério, em virtude da inibição dos mecanismos que costumam estimular a instabilidade”.

Note que, neste caso, é a presença da Zcit que proporciona a ocorrência do fenômeno. O auge do período chuvoso é o mês de agosto e a média pluviométrica anual já chegou a alcançar entre $1.400 \mathrm{~mm}$ e $1.750 \mathrm{~mm}$, desde a região dos Grandes Lagos até a Etiópia. A oscilação dos volumes pluviométricos se deve às condições da incidência solar e localização, em função da altitude e orientação do relevo, entre outros fatores, como a presença da biomassa vegetal (responsável pela evapotranspiração), cuja influência é predominantemente local ou regional.

Apesar de se localizar na latitude zero, o planalto do Lago Vitória registra índices pluviométricos (variando entre $1.200 \mathrm{~mm}$ a $1.400 \mathrm{~mm}$ ) inferiores aos do planalto etíope. Um fator importante que justifica isso é a barreira formada desde o Maciço Quilimanjaro até o do Quênia por influenciar diretamente sobre o fenômeno meteorológico. A diminuição desses valores em relação aos outros pode também justificar-se pela ausência dos fatores que, por sua vez, se apresentam na Etiópia, e não na região dos Grandes Lagos, conforme argumentado.

Por exemplo, no sul do Sudão do Sul, onde começa a Depressão Nilótica, ainda com favorecimento das condições da forma do relevo no intervalo das barreiras do Monte Quênia e do Planalto da Etiópia, as médias anuais de chuva variam entre $1.000 \mathrm{~mm}$ e $1.250 \mathrm{~mm}$.

Quanto mais se distancia para o norte da bacia do Rio Nilo, neste caso, não pode deixar de considerar a latitude, menores são os valores pluviométricos como os registrados no território do então Sudão, de $600 \mathrm{~mm}$ a $1.200 \mathrm{~mm}$ anuais. A região sudanesa agraciada por esses totais de chuva pode sofrer influência do planalto etíope, visto que o acompanha, paralelamente, até a sua intersecção onde começa a cadeia arábica. 
Apesar disso, na porção norte do Sudão a média é quase zero, como no Deserto da Núbia que tem sua formação influenciada, entre outros fatores, pelas massas de ar secas formadas no Saara como um todo, além do fator latitudinal.

Uma exceção dessa tendência de diminuição das médias pluviométricas ao longo da depressão do Nilo, no sentido sul-norte, é possível ser observada no delta. Lá a média anual alcança cerca de 100 mm, ao contrário do Cairo (Egito), que está antes dessa área, a montante, e que, por vezes, nem registra dados pluviais ao longo do ano.

$\mathrm{Na}$ análise geográfica, sabe-se que o clima influencia na vegetação, além de haver vínculo entre um e outro, ou seja, as condições de um elemento contribuem com as do outro e vice-versa. Significa dizer que na zona climática do Deserto Saara ocorrem as plantas xerófitas devido às condições do clima, o qual se caracteriza pela extrema falta de umidade, alta amplitude térmica diária e sazonal, e média de chuva anual inferior a $250 \mathrm{~mm}$, por exemplo, a Cidade do Cairo, no Egito.

Como se pôde observar, a média pluviométrica do delta do Nilo é inferior à classificada como de deserto. Dentro do domínio desse tipo de clima que se estende desde o Egito até o Sudão, está a parte do Baixo Nilo e, apesar da mata ciliar existente em alguns pontos seguindo o curso do rio, à medida que se afasta das margens é o tipo de vegetação desértica que predomina, à exceção das áreas irrigadas não longe do rio. Muitas plantas encontradas nessa região e na Bacia Hidrográfica São Francisco (na altura do semiárido) são conhecidas no Nordeste do Brasil como mandacaru, facheiro, entre outras já mencionadas. Essa vegetação é adaptada a esse tipo de clima em que predomina a aridez, mas também ocorrem em zonas semidesérticas ou que estejam sofrendo o processo de desertificação.

Até no semiárido africano, na bacia do Nilo, essas mesmas espécies vegetais são encontradas, além da presente vegetação herbácea, ressecada e esparsa, conhecida como estepe. Esta, no entanto, não pode ser confundida com as pradarias, características de clima de 
média latitude que, no caso da África, surge na faixa de transição entre climas úmidos e de deserto, apesar dessa vegetação de estepe ser encontrada também nos campos dos planaltos da Etiópia e dos Grandes Lagos. Ainda no semiárido, encontram-se vegetações de estrato arbustivo, caducifoliado e espinhoso, semelhantes às existentes na bacia hidrográfica do Rio São Francisco, também em sua região semiárida.

A faixa semiárida observada entre Sudão e Sudão do Sul é mais estreita do que a zona tropical que abrange além do segundo país mencionado - Uganda, Ruanda, partes ocidentais do Quênia, Burundi e Etiópia. O clima deste é relativamente diferente dos outros países devido ao seu relevo de elevadas altitudes, conforme anteriormente mencionado, o que favorece a existência de um tipo de vegetação também diferente, como florestas e campos. Esse tipo de vegetação, geralmente com extrato arbóreo, arbustivo e herbáceo, por vezes surge em forma de savana.

$\mathrm{Na}$ região do planalto dos Grandes Lagos, por causa de seu clima, conforme classificação já mencionada, predomina uma biomassa vegetal heterogênea, em função das condições de seu relevo e clima. Nas partes mais úmidas e mais quentes, consequentemente, a formação vegetal é higrófila e latifoliada, ou seja, adaptada a bastante umidade contínua e com folhas todo o ano, sendo essas folhas largas e que permitem intensa transpiração. Essa formação vegetal tropical compartilha o espaço dessa região com a savana que se desenvolveu em várias regiões da África, menos no extremo norte do continente, onde predomina a vegetação desértica ao longo do Saara. Note que, de acordo com o próximo mapa (fig. 13), parte dessa região que é banhada pelo Rio Nilo está entre o Sudão e o Egito.

Na cabeceira do Nilo, onde aflora uma das nascentes, na Região do Parque Nacional Kibira, circunscrição das montanhas do Burundi, a sua formação vegetal é tropical, todavia, por vezes, mostra algumas características do tipo de vegetação do planalto da Etiópia, por causa da elevada altitude em que se encontra, conforme já foi descrita. 


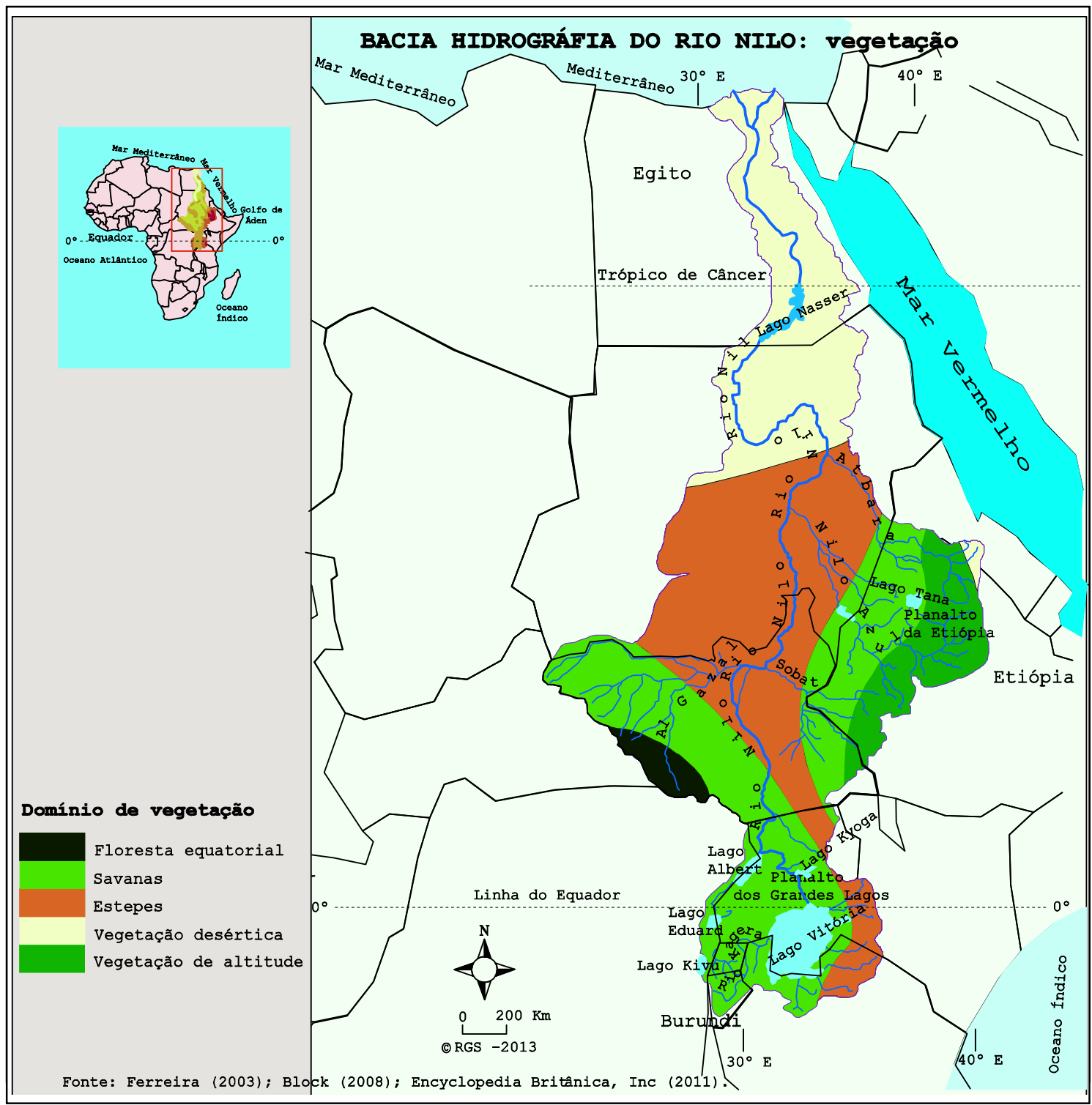

Figura 13. Mapa da Bacia Hidrográfica do Nilo - Vegetação.

É importante frisar que após os planaltos do Lago Vitória e próximo do planalto da Etiópia há uma região alagadiça, em conformidade com as cheias do Rio Nilo, a qual é denominada de Sud (conhecida como obstáculo pelos então mercadores árabes). Todo seu espaço formado pelas águas do Nilo Branco configura um verdadeiro pantanal e, por sinal, é considerado o maior do mundo. A vegetação predominante é de papiro branco, algo como uma espécie de junco, normalmente encontrada em planícies de várzeas. Estabelecendo uma relação com o Rio São Francisco em seu ciclo de cheias naturais, suas várzeas, neste caso, no baixo curso, só não eram tomadas pelo junco porque os ribeirinhos as tratavam para cultivar o 
arroz. O obstáculo observado pelos mercadores árabes na região africana, a qual se estende ao longo do Nilo Branco até pouco antes da confluência com o Nilo Azul faz sentido, entre outros fatores, pela notável dificuldade ao perfazer o curso do rio no sentido norte-sul e vice-versa.

Além da extensa área alagadiça com várias ramificações da água expandida por diversas partes, conforme o nível da grande depressão, há a presença do papiro, típico desse ambiente. Tudo isso vem configurar a região como uma possível barreira, isto é, a dificuldade do ser humano transitar nesse espaço fluvial. Acredita-se também que isso limitava a circulação entre o Egito e a região tropical através do Nilo.

Enfim, denotou-se que no existente vínculo entre as dadas condições da forma do relevo em relação às características do clima e da vegetação, foi possível notar que há várias semelhanças entre as bacias hidrográficas estudadas, conforme foram elencadas ao longo do presente feito.

Ratificam-se as assertivas acima, de acordo com Ab'Sáber (200-):

Guardadas as proporções, ele [Rio São Francisco] repete o Nilo, pelo fato de manter sua perenidade ao passar por regiões áridas. O grande rio africano atravessa um deserto, enquanto o São Francisco cruza sertões subequatoriais semi-áridos de marcante sazonalidade hidroclimática e fitogeográfica. A perenidade de ambos depende das precipitações recebidas nas suas cabeceiras e no médio-vale superior.

Além disso, o objetivo esperado com a abordagem sobre os aspectos físicos do espaço geográfico, visando à corroboração do conceito da Área de Influência Real de Empreendimentos Hidroelétricos do ponto de vista da Geografia (Airehg), foi alcançado. Em função de tais aspectos, a referida área se apresenta, de certo modo, ilimitada, pois ficou evidente que as características do clima e da vegetação são variáveis e não se limitam ao longo dos espaços hidrográficos, bem como também não impedem a revelação das semelhanças existentes na paisagem natural dos dois rios. 
Apesar disso, percebe-se que as duas bacias hidrográficas possuem limites pelos seus divisores de água. Ao mesmo tempo que isso é possível, não se pode deixar de frisar que os mesmos divisores não impedem sua transcendência pelos fatores naturais, conforme foram descritos e abordados.

Ao verificar as hipóteses secundárias, confirmou-se que tais aspectos físicos do espaço geográfico são variáveis e que constituem a Airehg através de suas semelhanças constatadas nas duas bacias hidrográficas, sobretudo nos baixos cursos dos rios. Neste caso, como se percebe, a maneira com a qual referida área está representada corresponde à perspectiva da paisagem natural.

É importante ressaltar que a paisagem natural do Baixo São Francisco possui um ponto que diverge do Baixo Nilo. Justamente no estuário do Rio São Francisco, são registrados índices pluviométricos expressivos, pois que chegam a ultrapassar os $1.000 \mathrm{~mm}$ anuais, os quais correspondem ao clima subúmido úmido, diferentemente do delta do Rio Nilo, onde pouco chove, alcançando cerca de $100 \mathrm{~mm}$ anuais em média.

Já na região da nascente do rio africano foi possível observar também que, onde a presença do clima tropical é marcante, a formação vegetal do tipo higrófila e latifoliada divide espaço com a Savana, além da presença de vegetação de campo.

Essas características naturais são bastante semelhantes às observadas no espaço do Alto São Francisco, pois a existência de vegetação herbácea é enfática na Chapada da Serra da Canastra, enquanto que o cerrado se estende ao longo dessa serra e de sua escarpa até alcançar a mata ciliar, acompanhando as margens do rio. Há ainda alguns remanescentes de mata atlântica dispersos nessa sub-região fluvial. Tais características estão, diretamente, condicionadas ao tipo de clima tropical que predomina nessa região do relevo brasileiro.

Após essa sub-região (alto curso dos rios), as duas referidas bacias hidrográficas sofrem os efeitos do clima semiárido, pois que, em função disso, as características fitogeográficas 
semiáridas passam a ser notáveis. Estas se destacam por possuírem uma formação arbustiva e xerófita, de modo que chegam a alcançar uma distribuição esparsa, por causa das condições do clima. As barragens hidrelétricas do rio brasileiro, que se encontram nesse espaço, têm perdas de água por evaporação; a de Sobradinho, no Estado da Bahia, está mais vulnerável à volatilidade do fenômeno natural por possuir o maior espelho d'água. Igualmente, acontece com o Lago Nasser, no caso do Rio Nilo.

Depois dos rios atravessarem o semiárido, os espaços fluviais do São Francisco e do Nilo apresentam aspectos naturais ligeiramente distintos. $\mathrm{O}$ primeiro atravessa o agreste e a zona da mata para desaguar no Atlântico, onde as chuvas são mais expressivas, o que corresponde a uma vegetação densa, a mata atlântica. $\mathrm{O}$ segundo rio avança por terras muito mais ásperas e enfrenta as altas temperaturas do clima desértico, atravessando o Saara. Referido clima, entre outros fatores, é responsável pela evaporação exacerbada ao longo desse espaço geográfico, com destaque para o lago de Alta Assuã, atingindo cerca de $16.000 .000 \mathrm{~m}^{3}$ (dezesseis milhões de metros cúbicos) anualmente, assim como não tem colaborado com o acréscimo de biomassa vegetal na região do deserto por tais razões.

\subsection{O ESPAÇO GEOGRÁFICO DO RIO SÃO FRANCISCO E DO RIO NILO NO ALVO DA MODERNIZAÇÃO: consequência para seus baixos cursos}

Ao se referir ao termo modernização, é de total importância esclarecer o seu sentido, visto que este tem sido bastante utilizado para representar o processo atual, inovador, transformador. Só não deve se esquecer de seu fundamento marcante em relação ao tradicional, isto é, o moderno tem como principal função negar o tradicional, conforme é possível assim compreender na concepção de Martins (1975). 
É importante assumir de início que o moderno a que se refere aqui, entre outros fatores, diz respeito à existência e operação dos empreendimentos hidroelétricos, além das infraestruturas socioespaciais engendradas a partir desse fator notável na paisagem cultural.

Toda discussão levantada tanto do aspecto da existência e operação das hidrelétricas, quanto da transposição do Rio São Francisco, converge para a concepção de como tudo isso pode intervir na organização socioespacial da bacia hidrográfica, assim como vem ocorrendo no Rio Nilo, exceto como se deu o caso da transposição.

Ou seja, os espaços geográficos desses rios estão no alvo da modernização de acordo com a abordagem que segue dentro desse contexto.

Todo o processo da modernização que aqui vem sendo interpretado se trata, sobremaneira, da análise da implementação dos empreendimentos hidroelétricos de tais espaços fluviais e, em segundo grau, a respeito do projeto de transposição do rio brasileiro. Nessa concepção, são consideradas as possibilidades das correlações que há entre os seres vivos e o meio ambiente. Por meio das quais, referida interpretação revela a ocorrência dos impactos ambientais e socioambientais que, ao serem analisados, mostram a proposição do presente feito e, enfim, confirmam a hipótese no desfecho deste capítulo.

Desse modo, referidos impactos se apresentam como variáveis da paisagem cultural, que são premissas fundamentais do conceito da Área de Influência Real de Empreendimentos Hidroelétricos do ponto de vista da Geografia.

A energia destaca-se como um dos principais fatores da modernização, pois a evolução tecnológica que, de acordo com Harvey (1992), é responsável pelo “encurtamento" do espaço do mundo não se confirmaria sem fazer uso daquela, independentemente de sua força motriz. Para compreender tal encurtamento do espaço implica entender antes a diminuição da distância, numa concepção de que o tempo suprime o espaço como bem observou Santos (1996). Igualmente, é preciso levar em consideração que "Os novos meios de transportes 
(construção de estradas e de veículos), energia (linhas de alta tensão), telecomunicações (telefone, transmissão de dados, internet) contribuem para diminuir os efeitos da distância." (THÉRY e MELLO, 2005, p. 235). Assim, em função desses aspectos, contextualiza-se a ideia de que um outro espaço se corrobora. Observe isso pelo seguinte exemplo: no início do século XX, um documento confirmando negociação de arroz do Vale São Francisco, enviado do Brasil ao Japão (cerca de $18.500 \mathrm{Km}$ de distância) por navio, levava cerca de 52 dias para chegar ao seu destino. Em contrapartida, hoje, no século XXI, um documento representando um processo de transação financeira sobre exportação de frutas produzidas no vale do rio brasileiro para o referido país asiático, anexado a um e-mail, após um clique na internet, chega ao mesmo destino de mesma distância, em poucos segundos. Percebe-se, portanto, que estes tempos de cerca de alguns segundos e de 52 dias, além das extensões a serem percorridas são tempos e espaços da mesma natureza, porém, com significados distintos. Isso faz entender que o mundo contemporâneo globalizado dá o sentido de um outro espaço. A distinção desses dois fatores pode se dar da seguinte maneira: dependendo das condições do transporte do documento em 52 dias, este pode estar mais exposto às avarias do tempo por ser mais longo; já o enviado no clique da internet, não sofre as avarias do tempo dos mesmos 52 dias, mas está sujeito às condições do tempo e espaço modernos como a uma falha ou pane no sistema programado. Vale lembrar que até mesmo os aviões estão sujeitos a isso ou a qualquer incidente, por exemplo, e já houve casos em que nem chegaram ao seu destino.

Tudo isso vem reforçar a concepção de como o espaço sertanejo da margem do Rio São Francisco, que outrora foi usado e ocupado por ribeirinhos tradicionais, hoje passa a ter significação em escalas diferentes, compreendendo a local, a regional e até a global, através da comercialização de hortifruti.

Esses fatores, característicos da organização socioespacial dessa parte sertaneja em que se encontra a Bacia Hidrográfica Sãofranciscana, são bastante notáveis no “complexo 
agroindustrial" Juazeiro/BA - Petrolina/PE. Esses dois municípios têm se destacado, atualmente, na economia a partir da produção de frutas do Vale Sãofranciscano, baseada na irrigação em larga escala, praticada pela agroindústria local e da região, além de atenderem ao mercado externo como a Ásia, Europa, Estados Unidos da América, e o mercado interno, principalmente São Paulo, na Região Sudeste brasileira, pela comercialização de frutas desse complexo. As uvas do Vale São Francisco já têm sido observadas nas gôndolas de rede de supermercados na cidade de São Paulo/SP, por exemplo.

Vale ressaltar que o espaço do Velho Chico (Rio São Francisco) será abordado num contexto socioambiental, ou seja, de que maneira o rio está sendo utilizado a partir de finalidades humanas, de modo que a ação antrópica, seus interesses e a natureza do espaço fluvial serão analisados em conjunto como um todo. Quando se trata da questão socioambiental, neste caso, a abordagem geopolítica se torna inevitável, principalmente em função do São Francisco ser um rio interestadual e a gestão de sua bacia hidrográfica estar envolvida no poder de vários governos estaduais, embora pertençam ao mesmo Estado-Nação (Brasil), devendo, portanto, submeterem suas decisões aos poderes federais (Legislativo e Executivo).

Neste caso, ao pensar o São Francisco como um rio de integração nacional, deve-se levar em conta sua grande complexidade espacial dentro do contexto socioambiental. Isso está relacionado não só à extensa bacia hidrográfica que integra os vários Estados brasileiros conforme já citados, mas também desde seus aspectos naturais, socioculturais, até os socioeconômicos.

A abrangência desses vários aspectos remete-se à abordagem desse espaço como tal porque, conforme já mencionado, vários sãos os climas e coberturas vegetais que caracterizam essa bacia hidrográfica. Igualmente, ocorre em relação a todos os outros aspectos que envolvem, nesta percepção, o espaço e o homem. 
Nessa concepção, bem observou Azevedo (1972) ao considerar, entre outros aspectos, especialmente sua dimensão geográfica, alguns dos que acima foram citados para comparar o Brasil a um Continente. Noutros termos, o autor observou em tal comparação os quadros naturais do país e, entre outros fatores, as disparidades socioespaciais notadas na Geografia Humana.

Nesse mesmo contexto, alguns aspectos do espaço geográfico do Rio Nilo serão abordados, porém, convém esclarecer que os aspectos geopolíticos envolvendo o referido rio se diferem, em termos, dos observados a respeito do Rio São Francisco, certo de que o rio africano não é como o rio brasileiro, de unidade nacional, pois aquele atravessa vários países conforme já citados anteriormente. Ou seja, a escala geográfica de sua bacia hidrográfica estende-se por território de domínio internacional, um dos principais fatores que indicam a complexidade existente quando se trata, entre outras coisas, de qualquer circunstância política a respeito da gestão de suas águas.

No caso do Nilo, em termos de comparação de dependência em relação a esse rio, pode-se dizer que o Egito está para o Sudão e Sudão do Sul como os dois primeiros estão para a Etiópia. O fato de realçar esses países se deve ao acordo de cooperação que há entre Egito, Sudão e Etiópia, segundo Nicol (2003).

O Egito, por ser o mais dependente do controle da vazão do rio, não hesitou em construir a Barragem Alta Assuã como estratégia de desenvolvimento social, político e econômico, tendo em vista que a grande maioria do contingente populacional está concentrada nas margens do Nilo.

Fazendo menção a tal estratégia, cabe frisar a geração de energia hidrelétrica e, sobretudo, o uso da água. É fato que, sem energia, fica difícil promover o desenvolvimento de um país, mas é o uso da água que se destaca no Baixo Nilo para abastecimento público, industrial, além de atender a irrigação em geral, sobremaneira a agroindústria de exportação. 
Com o desenrolar de várias dessas finalidades, voluntária ou involuntariamente, o rio é atingido pelo impacto ambiental e a sociedade passa a sofrer o impacto socioambiental, fatores relevantes que contribuem com a corroboração da principal hipótese do presente estudo.

É por causa do grande volume d'água que, entre outros motivos, a partir do início do século XX, o espaço fluvial do São Francisco passa a atender determinadas finalidades econômicas. A geração de energia hidrelétrica aparece como primeira importância e passa a se destacar após a execução do empreendimento hidroelétrico Complexo Paulo Afonso I, II, III e IV, em meados desse século, levados a efeito pela Companhia Hidroelétrica do São Francisco (Chesf), constituída a partir de 1945. A implementação dessa política teve como objetivo levar energia elétrica ao setor industrial no intuito de assegurar o desenvolvimento da região Nordeste, principalmente.

Nessa concepção, bem observou Sanches (2011b, p. 40):

A criação da Companhia Hidro-Elétrica do Rio São Francisco - Chesf pressupunha desenvolvimento regional da bacia do rio São Francisco com produção energética. Além de inaugurar a atuação direta do Estado na geração de eletricidade, passou-se a verificar a construção de usinas de grande porte e à dissociação entre a geração e a distribuição de energia elétrica. Assim, a expansão do parque elétrico brasileiro na década de 1950 obedeceria em larga medida ao modelo implementado na Chesf, ou seja, concentrar a produção em grandes usinas e suprir de energia os sistemas distribuidores regionais a cargo dos governos estaduais.

Assim, significativas transformações do espaço fluvial do Rio São Francisco coincidem com essas épocas em que foram executados os maiores empreendimentos hidroelétricos, atualmente instalados e em plena atividade. É importante destacar que antes mesmo desse complexo hidroelétrico, a Usina Hidrelétrica (UHE) Angiquinho, em Delmiro Gouveia/AL (antiga localidade denominada Pedra), que fica a jusante do município Paulo Afonso/BA, já fora instalada por volta de 1910, aproveitando a cachoeira Paulo Afonso. É importante esclarecer que essa usina não possui o porte dos empreendimentos em destaque, mas faz parte do histórico da ação humana empreendedora nas margens do São Francisco, visando o mesmo 
fim, a produção de energia. Já o Empreendimento Hidroelétrico Três Marias, que ocupou uma das maiores áreas, foi instalado no alto curso do rio, sendo que as obras de execução da represa se estenderam por volta de 1957 a 1962. Deu-se por essa época a continuidade do período marcado por tais transformações a partir do Complexo Hidroelétrico Paulo Afonso, que iniciou as obras de sua primeira usina em 1949, e a geração de energia só começou em 1954, segundo a Enge-Rio (1993b). Depois de Três Marias, em 1971, na circunscrição da área do referido complexo hidroelétrico que está situado, geograficamente, no médio curso do rio, foram iniciadas as obras do aproveitamento de Moxotó. A Barragem Sobradinho (iniciada em 1973), que tinha apenas a função de controlar a vazão, passa a gerar eletricidade a partir de 1979 e está também no médio curso do rio, assim como se localiza a UHE - Luiz Gonzaga (antiga Itaparica), que começou a gerar energia em 1988. Apesar de o Empreendimento Hidroelétrico Xingó, último a ser instalado (entre as décadas de 1980 e 1990) através do leito do rio e a sua jusante, ter entrado em atividade na era da democracia, a ideia de sua execução já começara no período histórico brasileiro anterior, o período militar.

A atenção dada à implementação de políticas energéticas tem sido justificada por causa do desenvolvimento do país, com ênfase no setor industrial, tanto que, segundo Sanches (2011a, p. 40, grifo do autor), "Desde a Revolução Industrial o acesso à energia passou a ser sinônimo de desenvolvimento, sendo sua ausência considerada fator de atraso social e econômico e, consequentemente, de pobreza".

Considerando o contexto da abordagem feita acima sobre o Rio São Francisco, em termos de comparação com o Rio Nilo, e levando em consideração também a escala geográfica internacional deste, vale ressaltar que, do século XIX ao XX, os acordos geopolíticos, visando à gestão do recurso hídrico do Nilo, envolveram tanto os países banhados por este rio, quanto outros que contribuem com o aumento de sua vazão, a saber: República Democrática do Congo e Eritreia são países contribuintes, enquanto Burundi, 
Ruanda, Tanzânia, Quênia, Uganda, Sudão do Sul, Sudão, Etiópia e Egito têm suas terras banhadas pelo extenso rio, ao considerar sua mais distante nascente e seu delta.

Desde 1987, quando iniciaram as obras da UHE - Xingó, até 2017 são calculados 30 anos da ação política interventora direta no leito do São Francisco, naquele ponto. Esse tempo é razoável em desenvolvimento de política de longo prazo, na qual se classifica a política de energia elétrica desenvolvida junto ao Empreendimento Hidroelétrico Xingó. O fato mais grave é que os impactos socioambientais acarretados por esse empreendimento não foram corrigidos ou mitigados, apesar do evento já ter atingido, pelo menos, o médio prazo.

Apesar de essa fonte energética ter se destacado, nos últimos anos, devido aos investimentos do Estado para desenvolvimento do setor, há segmentos (Movimento dos Atingidos por Barragens (MAB), por exemplo) da população brasileira que têm uma esperança: a diminuição dos investimentos direcionados a essa fonte de energia. Com isso, esperam que o número de futuras execuções de tais empreendimentos não aumente, pois, dessa forma, o povo ribeirinho estaria livre de novos impactos ambientais e sociais. Uma das razões para a concretização dessa esperança é que, de acordo com Tinoco (2010), até 2050, 93\% da eletricidade brasileira possa ser produzida a partir de fontes renováveis como a solar, eólica ou biomassa. Segundo a autora, isso poderá garantir a geração de 3.000 .000 (três milhões) de empregos na área de tecnologia de ponta, além de ajudar o país a diminuir suas emissões de gases do efeito estufa.

\subsection{UMA BREVE REFLEXÃO SOBRE A TRANSPOSIÇÃO DO RIO SÃO FRANCISCO}

Entre outros fatores de configuração socioespacial da Bacia Hidrográfica Sãofranciscana, merece destaque a transposição de suas águas. Entre outras razões, a 
polêmica do tema que se sobrepõe, por suas consequências, a um dilema entre transposição e revitalização do rio será abordada numa discussão crítica.

Não é só nos Estados banhados por esse rio que há oposição de grande parte do povo a respeito dessa ação delicada sobre o meio ambiente, mas até "Na Paraíba, esta oposição também é exercida não pelos filhos da classe média alta que foram influenciados pelo ambientalismo do Norte, mas por pessoas que estão em contato com os problemas do cotidiano dos mais pobres.” (MENEZES e ROCHA, 2010, p. 9).

Tudo indica que a falta de gestão pública eficiente do recurso hídrico é uma justificativa, entre outras, de que essa ação antrópica sobre essa bacia hidrográfica não é adequada às condições ambientais, tampouco venha atender aos aspectos de justiça social, pois para Menezes e Rocha (2010, p. 9): “[...] no Nordeste, não é a falta de água que gera a fome, mas a concentração da mesma, junto com uma situação fundiária injusta há séculos. Se assim não fosse, não haveria fome nos mangues paraibanos ou nas margens dos rios e das grandes barragens".

Como se não bastassem as consequências socioespaciais notórias nas margens e no leito do rio, engendradas a partir dos vários empreendimentos instalados ao longo de seu curso, a transposição de suas águas está sendo executada, o que é inviável ambientalmente. Essa inviabilidade, entre outros fatores, evidencia-se do ponto de vista da perspectiva do estudo da previsão de impactos, ao considerar que o espaço geográfico beneficiado pela transposição enfrenta o processo de estresse hídrico (uso do recurso hídrico com maior intensidade do que está disponível em uma bacia hidrográfica) por causa da pressão pelo uso da água entre o século passado (séc. XX) e início deste século (séc. XXI). Assim, isso pode ser um importante condutor a principiar o estresse hídrico na Bacia São Francisco, na medida em que a densidade demográfica do semiárido como um todo está mais elevada hoje em dia do que no passado. Certamente, o fator densidade demográfica pesará quanto à pressão pelo uso da água 
na bacia hidrográfica do Vale São Francisco em função da sua abrangência espacial e virá a se acentuar, ainda mais, fazendo uso a partir dos canais da transposição.

Além disso, qualquer evento de degradação da qualidade ou do comprometimento do abastecimento de água ocorrido a montante do rio a partir da represa Luiz Gonzaga (antiga Itaparica) até as cabeceiras, expõe toda a população ligada aos canais da transposição a tais impactos.

O sentido da ampliação da área de influência não se estagna nesses aspectos, mas deve abranger também até a foz do rio e todos os pontos com o qual possuam relação, pois o uso da água sempre chamará a atenção em função do volume do rio que não se manterá o mesmo. Este fato está representado por meio das informações interpretadas a partir dos dados de vazão registrados nos reservatórios do São Francisco, de acordo com o presente estudo.

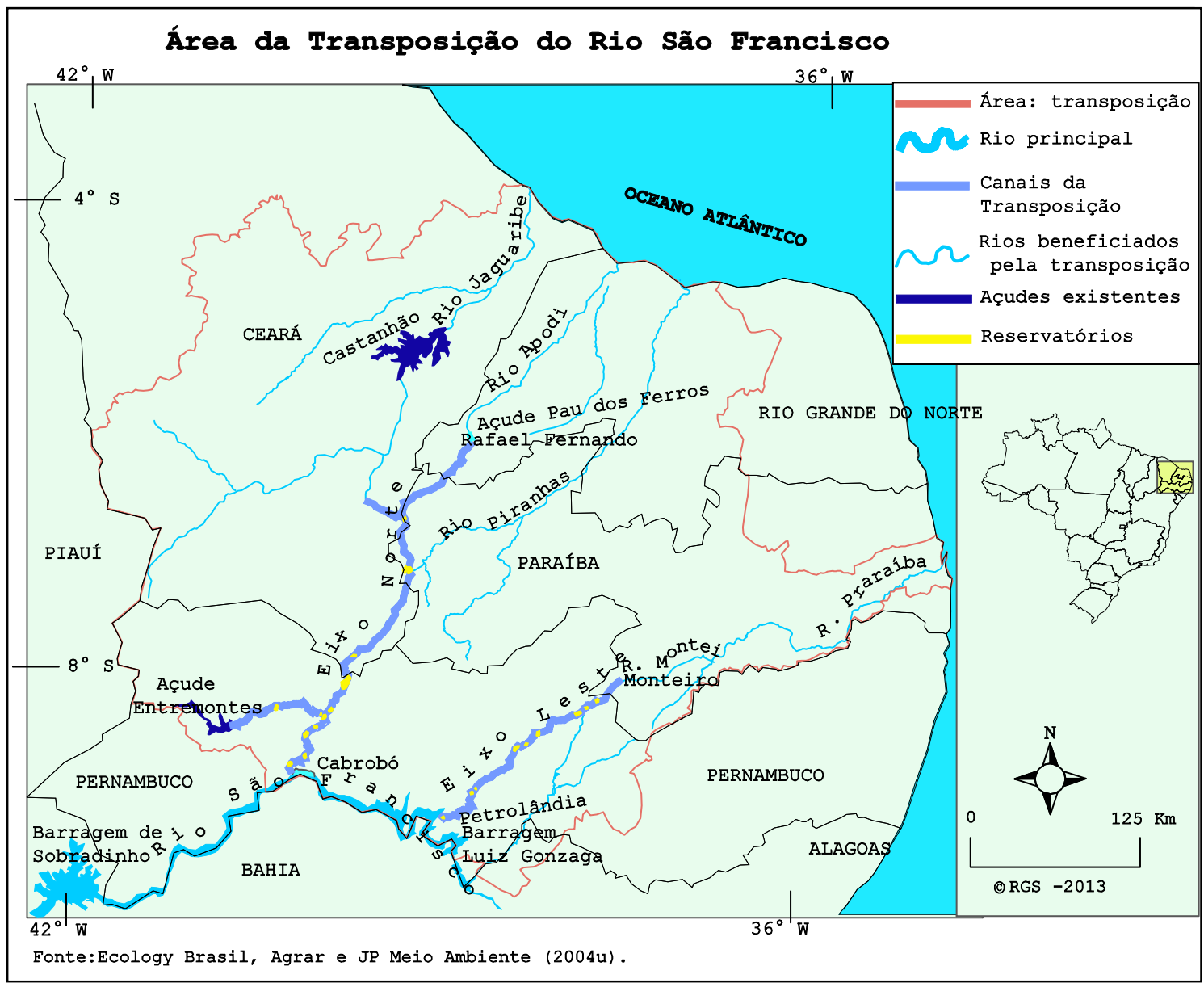

Figura 14. Mapa da transposição do Rio São Francisco. 
Da análise da pesquisa, observando o mapa (fig. 14) anterior, é possível perceber, no âmbito de uma visão prospectiva de território, que a área da transposição tenderá a um aumento de densidade demográfica, dentre outros fatores, haja vista à disponibilidade hídrica a partir dos canais da referida transposição. Sabe-se que o fator existência de água foi, historicamente, uma das principais condicionantes do processo de povoamento em determinados lugares com tal disponibilidade, resultando, normalmente, em aumento de densidade demográfica. Com efeito, isso implicará em certa pressão pelo uso do recurso hídrico ao longo do tempo, o que não tem sido diferente na gestão das barragens instaladas no leito do São Francisco, tendo em vista a grande contenção de água, de modo que no baixo curso do rio seus aspectos naturais vêm sendo desconfigurados.

É importante frisar que, da análise da pesquisa, há evidências de que o aumento da densidade demográfica em tal espaço venha se confirmar em função de futuras instalações agroindustriais por causa da disponibilidade hídrica. A afirmação de representante de instituição pública conferida através de entrevista que consta ao longo do presente texto corrobora a assertiva acima. Isso chama a atenção porque, a exemplo deste caso, a abundância de água disponível no Polo Juazeiro/BA - Petrolina/PE tem se mostrado como fator de aumento de densidade demográfica não pelo fácil acesso à água por si só, mas também pela existência da agroindústria, revelando disparidades socioespaciais. Por essa razão, foi possível observar em tal polo uma infraestrutura privada centrada no poder do capital que se sobrepõe ao poder legítimo do ribeirinho quanto ao uso da água do rio. Ratificam-se as assertivas conforme bem observou Barros (2009, p. 232, grifo nosso):

Assim, embora o pólo xérico de fruticultura irrigada Petrolina-Juazeiro seja definido como um pólo de desenvolvimento regional, é necessário enfatizar que essa escala espacial não foge às conseqüências perversas da economia capitalista. São inúmeros os movimentos sociais que reclamam por terras, águas, incentivos governamentais, trabalho, condições dignas de trabalho e mais garantia de políticas públicas sociais, fatos que desafiam frequentemente o movimento paradoxal de desenvolvimento e fartura anunciada nessa que se configura, atualmente, como escala local dos 
comandos hegemônicos dos grupos empresariais nacionais e transnacionais.

Tais críticas se remetem à maneira como determinadas ações políticas são aplicadas e, principalmente, à falta de efetivação de programas correlacionados às mesmas ações. Ou seja, as análises espaciais ao longo do tempo entre o final do século passado (séc. XX) e início do século presente (séc. XXI), a respeito da Bacia Hidrográfica São Francisco, elucidam por que dirigir tais críticas. Para melhor compreensão, basta retomar a discussão sobre os impactos socioambientais engendrados nesse espaço fluvial por causa da execução dos vários empreendimentos hidroelétricos em que, pelo menos no caso da UHE - Xingó, ainda não foram executados relevantes programas de mitigação dos impactos, de acordo com Santos (2008). Muitas várzeas que sustentavam o desenvolvimento de comunidades locais em vários municípios ribeirinhos estão abandonadas, já que as águas do rio não as alcançam por causa da grande redução de sua vazão, tampouco se detectam projetos de irrigação desenvolvidos socioambientalmente adequados nessas áreas.

Seguindo essa linha de raciocínio, denota-se a necessidade de desenvolvimento de projetos de irrigação por gotejamento e que sejam acompanhados por técnicos competentes para orientarem o uso e manejo do solo e da água, além das relações pessoais envolvidas nesse tipo de atividade, no mínimo complexa (relação com o rio num novo tempo de espaço apresentando elevados índices demográficos). Entre outros programas de correção dos impactos socioambientais, que nunca foram implementados, merece destaque o Canal Xingó, destinado a banhar a área sertaneja dentro da Bacia São Francisco, abrangendo seu baixo curso.

É por essa e outras inconveniências que o Projeto de Integração do Rio São Francisco com Bacias Hidrográficas do Nordeste Setentrional (a transposição) merece ser criticado. Por exemplo, o programa de revitalização do rio não está sendo executado efetivamente, conforme consta no seu EIA/Rima, Ecology Brasil, Agrar e JP Meio Ambiente (2004m), 
como sendo de recomendação imediata, e que deveria anteceder a qualquer outra ação interventora no leito fluvial. Em contraposição à referida recomendação do EIA/Rima, a execução das obras empreendedoras já está bem adiantada, de acordo com a presente pesquisa (vide figura 15).

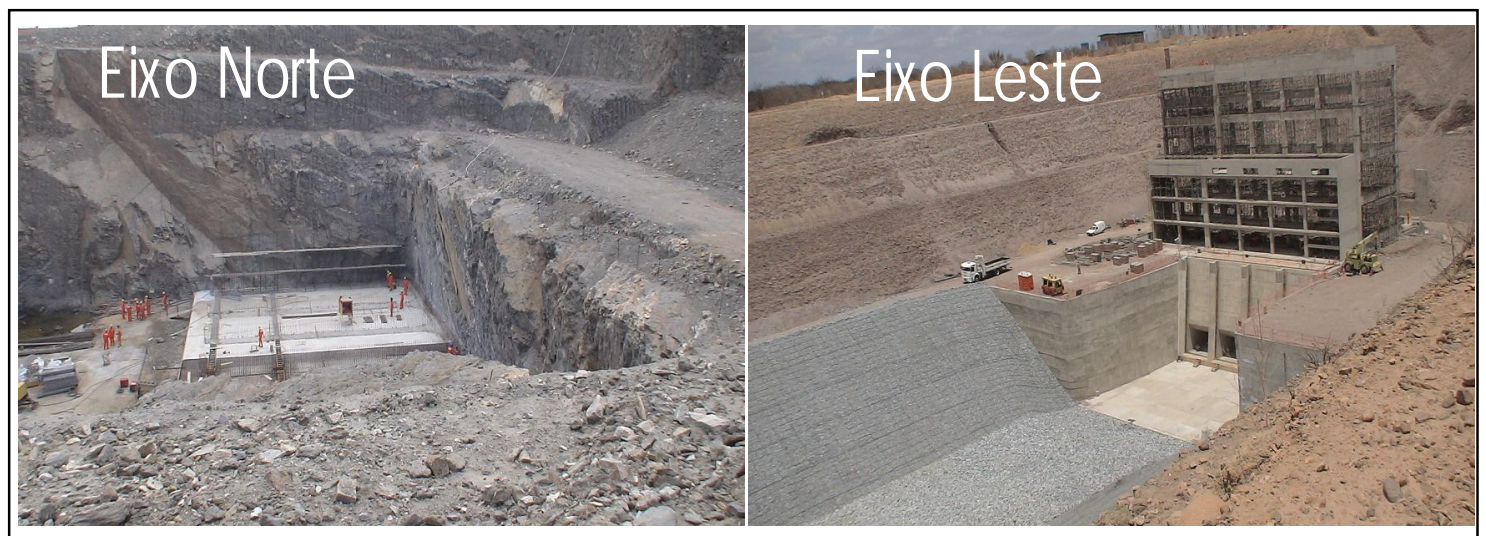

Figura 15. Estações de bombeamento dos eixos Norte e Leste da transposição a partir do Rio São Francisco. Fonte: foto do autor, janeiro de 2013.

É imprescindível frisar também que a revitalização não deve se limitar a um ponto aleatório ou específico do rio, mas se estender por toda a bacia hidrográfica, tanto nas suas cabeceiras, quanto nas de seus afluentes, até a foz do rio principal. Da mesma maneira que é necessário manter o volume fluvial a partir da preservação das nascentes, é também muito importante prevenir o assoreamento ao longo de todo o curso desde a nascente até a foz do São Francisco e de todos seus afluentes e, entre outros fatores, tratar os esgotos antes de destiná-los ao rio.

Ao tratar do assunto abordado, para Ab'Sáber (200-): “Sobre a viabilidade ambiental pouca coisa se pode adiantar, a não ser a falta de conhecimentos sobre a dinâmica climática e a periodicidade do rio que vai perder água e dos rios intermitentes-sazonários que vão receber filetes das águas transpostas".

Quanto à afirmação do autor, é possível ir mais adiante. Ou seja, é fundamental ressaltar que a transposição do rio se somará às causas dos impactos socioambientais já observados no Baixo São Francisco, certo de que o esperado no espaço fluvial é a diminuição do seu volume 
d'água na região. Com isso, o drama da população ribeirinha do baixo curso figurará um impacto imensurável, de forma que já não se consegue pescar os mesmos peixes e muito menos em mesma quantidade para se alimentar, nem se cultiva o arroz através do ciclo natural de cheias por causa de sua extinção. Significa dizer que o meio ambiente será atingido e, por conseguinte, isso resultará em consequências drásticas no meio social, cada vez mais desfavorável ao desenvolvimento sustentável, de modo que referidos impactos não estão sendo, pelo menos, mitigados, tampouco corrigidos. Assim, o que se difere dos impactos socioambientais da transposição sobre o Baixo São Francisco e os que foram observados no estudo "Impactos Socioambientais à margem do Rio São Francisco" conforme Santos (2008) é a soma das consequências sobre os espaços vulneráveis a essas adversidades. Além disso, amplia ainda mais a área de influência dos empreendimentos hidroelétricos situados a montante dos pontos de capitação dos eixos da transposição. Posto isto, qualquer agravante em relação à disponibilidade ou qualidade da água compromete todos os lugares conectados a tais eixos, pois estes ficam vulneráveis aos impactos ambientais e socioambientais. O tema da transposição se sobressai no contexto exemplar, mas no sentido de se adquirir experiência através de ações políticas que não foram corretamente aplicadas. Significa dizer que essa ação não poderia se confirmar, por causa dos danos já causados ao meio e à sociedade que dependiam direta e indiretamente do rio antes da existência da UHE - Xingó.

Essa discussão, inevitavelmente, converge para a questão da água com seus mais diversos temas destacados, muitas vezes, por veículos da imprensa escrita, falada ou televisiva. No entanto, esses meios informativos não têm dado a atenção merecida ao assunto a respeito de vários lugares que enfrentam tal problema. Pode-se dizer que isso reflete diretamente na organização socioespacial da Bacia Hidrográfica Sãofranciscana, de maneira a revelar muitas disparidades ao longo de seu espaço. Ratificam-se as assertivas acima conforme Venturoli (2009, p. 28): 
A disparidade entre o consumo de água por ricos e pobres constrói uma perversa lógica de mercado. À população carente sem acesso ao serviço de fornecimento de água restam duas tristes opções: ou longas caminhadas diárias até poços e reservatórios ou a compra de água de fornecedores particulares agueiros ou caminhões-pipa. Nas duas situações, os prejuízos econômicos e sociais são imensos [...].

É relevante frisar que situações dessa natureza acontecem próximo às margens do rio em epígrafe. Nessa concepção, em uma das visitas de campo, foram observadas inúmeras queixas da população de um povoado (Lagoa do Rancho) do município Porto da Folha-SE, a respeito da falta de água que perdurava, segundo os moradores dali, por cerca de uma semana. Esse episódio foi observado em janeiro de 2012. Nota-se que o povoado possui rede hidráulica de abastecimento e não fica muito distante do rio, pois o município ao qual pertence é ribeirinho. Uma saída para os que tinham melhor poder aquisitivo foi buscar água em caminhão-pipa.

O aspecto ideológico de tal discussão, por vezes oculto e por vezes podendo vir à tona, de acordo com a abordagem, conforme a análise contextual da organização em que se encontra o espaço ou poderá vir a se configurar, não pode deixar de ser definido. O que se espera tratar aqui não é apenas inferir que águas do Rio São Francisco serão transpostas para outras bacias, mas explicitar a transcendência desse entendimento, buscando aproximar-se de sua complexidade. Ainda que a transposição perpasse pela zona rural, principalmente, para ratificar a ideia implícita no contexto a se desenvolver, não se pode negar a relação existente entre esse caso e fatos com concepções de mesma natureza, observados na zona urbana.

Logo, esse contexto converge para o caso da transposição do Rio São Francisco ao considerar o seguinte: tudo indica que os pequenos produtores, sem poder aquisitivo competidor e sem infraestrutura, venham ocupar as margens dos canais, no futuro, mas que os detentores do capital não ficarão fora desse espaço e, além de tudo, poderão ser beneficiados por aqueles, através de mão de obra barata, conforme o número de membros que compõem tais famílias dos lavradores. 
Se a transposição do Rio São Francisco fosse de fato eficiente para corrigir a injustiça social notória no sertão nordestino, seria, assim, uma ação comum (para todos) e inteligente. No entanto, da maneira com que as análises vêm se revelando sobre o tema, com sua natureza contraditória no campo, tudo indica que essa ação se caracteriza como capitalista, visando interesses de terceiros. Quer dizer, a água que muitos esperam ser destinada para a dessedentação humana e animal, é crível que vá abastecer a agroindústria, conforme debates públicos a respeito do assunto. Dessa forma, estima-se que os capitalistas agricultores vão se sobrepor aos interesses legítimos da maioria, os de atenderem as necessidades dos camponeses que sobrevivem nas margens dos canais da transposição.

Nesse sentido, analisando a entrevista do presidente da Federação das Indústrias do Estado da Paraíba (Fiep), concedida à revista Piauí (2012), é possível notar o que poderá ocorrer no espaço geográfico das margens dos canais da transposição e em sua volta. Isso se apresenta como a tendência que vem configurando o espaço da bacia hidrográfica do Rio São Francisco, além do desenvolvimento do modelo neoliberal que vem se expandindo pelo espaço dos canais ligados ao Rio São Francisco.

Justificam-se as assertivas acima, tanto que, segundo Scarpin (2012, p. 32):

Para Gadelha [presidente da Fiep], o Nordeste está crescendo 'num ritmo chinês', mas a partir de um patamar muito baixo, que só a transposição poderá corrigir. Adiantando-se ao final das obras, ele montou escolas do Senai no interior da Paraíba para a formação de trabalhadores na indústria de sucos, extrato de tomate, ketchup e vinho. [...].

A Paraíba é o estado mais pobre em recursos hídricos do Brasil, e também o que será mais beneficiado com a transposição. A segunda maior cidade do estado, Campina Grande, tenta até hoje reviver seu passado glorioso. Entre os anos 10 [1910] e 30 [1930] do século passado, quando sua produção de algodão só ficava atrás da de Liverpool, na Inglaterra, a cidade viu a população aumentar em $650 \%$. [...].

Irmão de Marcondes Gadelha, deputado relator do Grupo de Trabalho da Transposição do Rio São Francisco durante o governo FHC [Fernando Henrique Cardoso], o presidente da Fiep não esconde seu ressentimento com o tempo que o projeto levou para decolar.

Nesse sentido, segundo Oliveira (2005, p. 227): “Como é sabido, nos modelos de desenvolvimento adotados no País, os interesses que direcionam os investimentos públicos 
estão voltados mais ao capital transnacional do que às necessidades das populações locais ou regionais". Esse é um dos maiores problemas que a sociedade brasileira enfrenta em muitos aspectos, pois quando a população é atingida de maneira negativa por uma determinada situação, normalmente, tal situação reflete noutra e esta desencadeia outra, e assim sucessivamente, resultando em um problema complexo. Se o contrário ocorrer (se for organizado), a situação passa a refletir de modo positivo no social e passa a atingir todo o desenvolvimento local, regional e até, dependendo da boa gestão, o global.

Nota-se que o fenômeno do capital, na sua ação, nega o valor tradicional do camponês, por exemplo. A infraestrutura da transposição já não é a mesma realidade com a qual o sertanejo conviveu ao longo da história daquele espaço, e se revela de maneira contraditória na zona rural. Zona esta que sempre deu as condições, apesar de precárias, de sustento do sertanejo passa a ser encarada de outra forma, como ocorreu no entorno de grandes reservatórios dos empreendimentos hidroelétricos do Rio São Francisco, principalmente no caso do polo Juazeiro/BA e Petrolina/PE. A infraestrutura montada pelo Estado, ao invés de atender fundamentalmente à sociedade em comum, promove a condição atrativa ao desenvolvimento do capital, que tem por sua natureza a busca incessante do lucro, a todo custo.

No âmbito desta discussão da transposição do Rio São Francisco é importante destacar que há quem acredite que essa interferência no referido rio não poderia se ratificar como está sendo executada, a saber:

Para Alves Filho (2000, p. 73), o Rio Tocantins é:

[...] um rio amazônico, relativamente próximo do Semi-árido, com uma vazão abundante, apto a fornecer toda a água adicional de que o São Francisco necessite, sem promover o menor prejuízo ao seu curso normal. Para termos de comparação, enquanto a vazão regularizada do São Francisco, após Sobradinho, é de $2.060 \mathrm{~m} / \mathrm{s}$, o Tocantins dispõe de uma vazão de $11.000 \mathrm{~m}^{3} / \mathrm{s}$, isto é, 5,5 vezes maior! 
Isso significa que, antes do Rio São Francisco ser interferido, o volume de seu curso deveria ter relevante ganho a partir do Tocantins (rio amazônico) conforme acima foi citado. Deveria também haver a revitalização de sua bacia hidrográfica ao longo do leito fluvial.

Para tanto, é necessário um EIA/Rima bem elaborado por competente, respeitável e consciente (em seu mais amplo sentido) grupo de cientistas e técnicos multidisciplinares e que respeite todos os parâmetros legais, além de atender aos critérios revelados pela ciência geográfica. Por fim, a execução do desenvolvimento do projeto só poderia se iniciar após ser constatada viabilidade plena. Espera-se que, no EIA, ao constatar impacto ambiental ou socioambiental, sejam apresentados meios correspondentes com a certeza de corrigi-los imediatamente ou a curto prazo.

\subsection{A ORGANIZAÇÃO ESPACIAL EM FUNÇÃO DAS HIDRELÉTRICAS E SUAS CONSEQUÊNCIAS: o caso do Rio São Francisco comparado ao do Nilo}

Tratar dos empreendimentos hidroelétricos como um fator moderno se deve à maneira como o espaço vem se organizando, às margens dos rios São Francisco e Nilo, em função da existência e operação dos referidos empreendimentos, conforme é possível conferir a seguir. Ou seja, o sentido do moderno representado na organização espacial de tais bacias hidrográficas se ratifica, principalmente, por causa da existência e operação das usinas hidrelétricas.

Por essas e outras razões, a abordagem das possibilidades da relação existente entre o homem e a natureza continua sendo feita através da análise da paisagem cultural. Tal análise se realiza tomando como ponto de partida as variáveis das características físicas do espaço geográfico abordadas anteriormente, visto que por meio das quais se confirmam as possibilidades da ação humana no espaço geográfico. 
Do alto ao médio curso do Rio São Francisco, foram observados fatores que revelam a interpretação da ideia de modernização.

São desde rodovias bem construídas, com leitos largos, até aeroportos, entre outros tipos de planejamentos, que configuram a infraestrutura estatal, ligando os pontos dos empreendimentos hidroelétricos a importantes centros da região. Pode-se perceber que isso se apresenta como estratégia de um fim, o qual só pode ser o desenvolvimento capitalista. Já que os mais pobres não possuem bens imóveis ou qualquer outro bem que possam penhorar junto ao banco em caso de empréstimo para desenvolvimento hidroagrícola e, pior, também não têm, sequer, um pedaço de terra para cultivar, logo, é possível afirmar que essa infraestrutura executada pelo Estado atende, principalmente, aos interesses do capitalismo.

Neste caso, analisando essa extensa bacia (que possui mais de $80 \%$ de sua área total inserida nos Estados de Minas Gerais e Bahia) é possível perceber inúmeras disparidades socioespaciais. A partir de seu alto curso em Minas Gerais e atingindo parte do médio, a estrutura socioespacial ${ }^{*}$ se configura com características de qualidades muito distantes das apresentadas no interior da Bahia. Tais características apresentam-se, sobremaneira, no Estado de Minas Gerais, ainda na proximidade da nascente, na altura da Represa Três Marias. Os habitantes dessa região têm significativas melhores condições de vida em relação aos do Estado nordestino, como também aos do baixo curso fluvial, com destaque para os sertanejos.

O clima tem participação importante nesses aspectos, mas as políticas territoriais e sociais que se desenvolvem em determinados pontos pesam mais que as condições climáticas. Significa dizer que detentores do capital se beneficiam, por exemplo, do recurso hídrico da Represa Três Marias, inclusive quando as condições climáticas não se apresentam favoráveis à agricultura, a despeito das políticas de recursos hídricos que não atingem os mais pobres

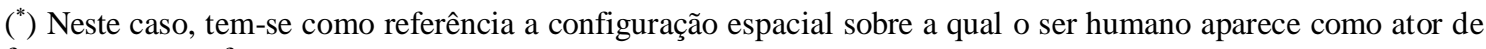
formação e transformação. 
igualmente $^{7}$. Entende-se, com isso, que a agricultura familiar não dispõe de capital para implantar a irrigação.

Percebe-se, com isso, algo comparável ao que observou Azevedo (1972) sobre o "Brasil continental", só que não se dá na mesma dimensão, mas ocorre de maneira bastante parecida. Ou seja, ao longo de um espaço banhado por um fluxo fluvial com extensão de cerca de 3.000 $\mathrm{km}$ se apresentam tantas estruturas sociais e espaciais com tantas disparidades.

Na região da citada represa há razoável estrutura de malha rodoviária que dá acesso tanto à UHE - Três Marias, quanto à UHE - Furnas que pertence à outra bacia hidrográfica (Rio Grande). Esse é um dos principais fatores, assim como a existência da barragem daquela UHE, que caracterizam as políticas territoriais dessa área da bacia hidrográfica do Rio São Francisco. Essa é uma das razões dos altos valores das terras em volta da Três Marias, pois estima-se que favoreça o desenvolvimento do "fenômeno da segunda residência", observado por Larrabure (2009), às margens do Rio Grande que corre na vertente oposta da Serra da Canastra, em relação ao São Francisco. Como o próprio nome indica, a segunda residência é uma segunda propriedade para se ocupar apenas nos momentos de lazer, como em períodos de temporadas ou férias, sendo que os seus proprietários têm suas residências fixas noutros lugares. Ratificam-se as assertivas acima, de acordo com Larrabure (2009, p. 99):

As construções das barragens, aliadas à grande distância do litoral e ao grande número de pedágios existentes nas rodovias brasileiras, ajudaram a impulsionar o aparecimento de 'subúrbios de veraneio', alterando significativamente a paisagem e modificando a vida cotidiana da população local. Essa área tornou-se conhecida na região, principalmente devido ao seu caráter elitista, criando a necessidade na parcela mais rica de possuir uma residência no local.

No município Felixlândia/MG, o espaço do Residencial Estância das Garças, banhado pela represa Três Marias, vem se apresentando com a mesma função observada na área

\footnotetext{
${ }^{7}$ RODRIGUES, Roberto Carlos. Secretário Municipal de Agricultura de Três Marias/MG. Entrevista concedida a Regnaldo Gouveia dos Santos. Três Marias/MG, 02 de julho de 2012. Informou que "Existe irrigação a partir da represa, mas só pra agricultura empresarial; pra agricultura familiar, não”.
} 
estudada por tal autora. Observou-se que a maioria dos proprietários desses imóveis reside em Belo Horizonte/MG conforme informações na pesquisa ${ }^{8}$.

Referida área da Bacia Hidrográfica Sãofranciscana dista cerca de 200 km (duzentos quilômetros) da capital mineira, Belo Horizonte, bem mais próxima do que a estudada por Larrabure (2009), o que torna o acesso mais fácil para quem parte dessa capital naquela direção. As pessoas dessa região não sofrem as mesmas consequências por motivo das estiagens enfrentadas pelos sertanejos nordestinos, a partir da Bahia até Sergipe e Alagoas, tampouco apresentam as mesmas qualidades de vida, razão pela qual a área coletora mais importante do rio se localiza, pelo menos, desde a nascente até a represa de Sobradinho. Isto é, a grande quantidade de afluentes nessa altura do curso do rio contribui, significativamente, para o desenvolvimento da economia, por exemplo, a agricultura.

Ao observar a imagem (fig. 16), pode-se notar, além da organização espacial na orla da Represa Três Marias, modelos das "segundas residências" modernas, que vêm configurando a paisagem do espaço.

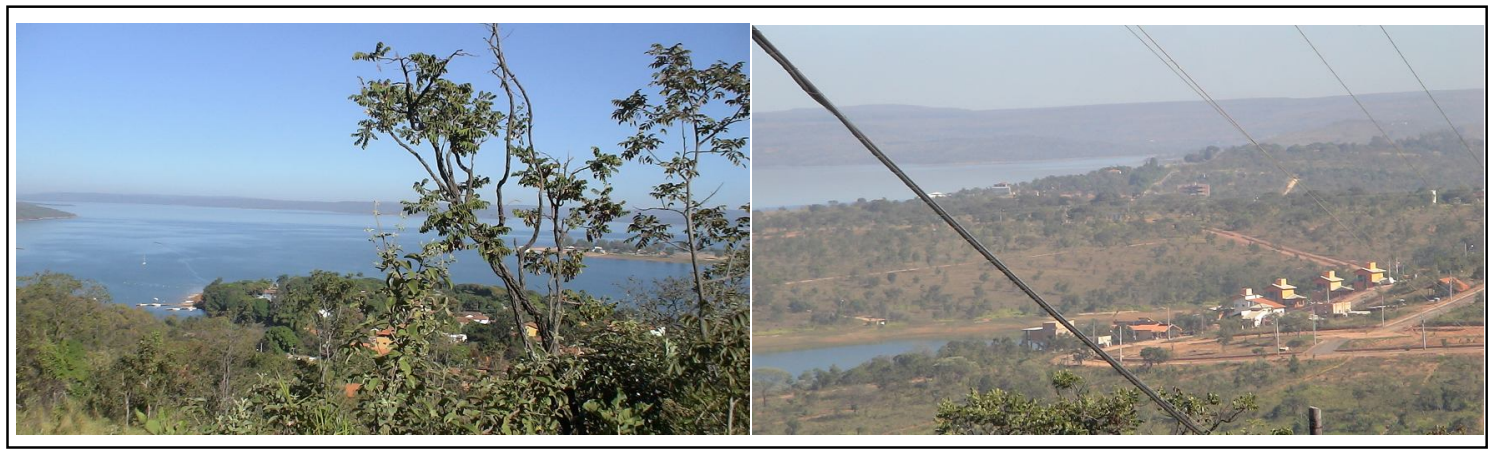

Figura 16. Organização espacial em volta da Represa Três Marias, no Rio São Francisco, município Três Marias/MG. Fonte: foto do autor, julho de 2012.

\footnotetext{
${ }^{8}$ NASCIMENTO, Maria Anunciada Júnior do. Mora há 35 anos no Residencial Estância das Garças Felixlândia/MG. Entrevista concedida a Regnaldo Gouveia dos Santos. Felixlândia/MG, $1^{\circ}$ de julho de 2012. Sobre a procedência das pessoas que usufruíam tal espaço, a entrevistada respondeu: "Da capital minera, que é Belo Horizonte. Aqui num tem ninguém que tenha rancho aqui que seja daqui da região nossa aqui, que daqui da onde eu moro pra Felixlândia são quatorze quilômetro”.
} 
Neste caso, é importante frisar que no Médio São Francisco, hoje em dia, há grandes disparidades no Polo Juazeiro/BA - Petrolina/PE quanto à posse das terras ribeirinhas, de acordo com o que se constatou na pesquisa ${ }^{9}$.

Observe na figura 17 abaixo, como se destaca uma das propriedades agroindustriais do referido polo, de modo que, no segundo plano da paisagem, é possível notar um signo da capitalização do campo, uma máquina moderna utilizada no tratamento do parreiral de uvas.

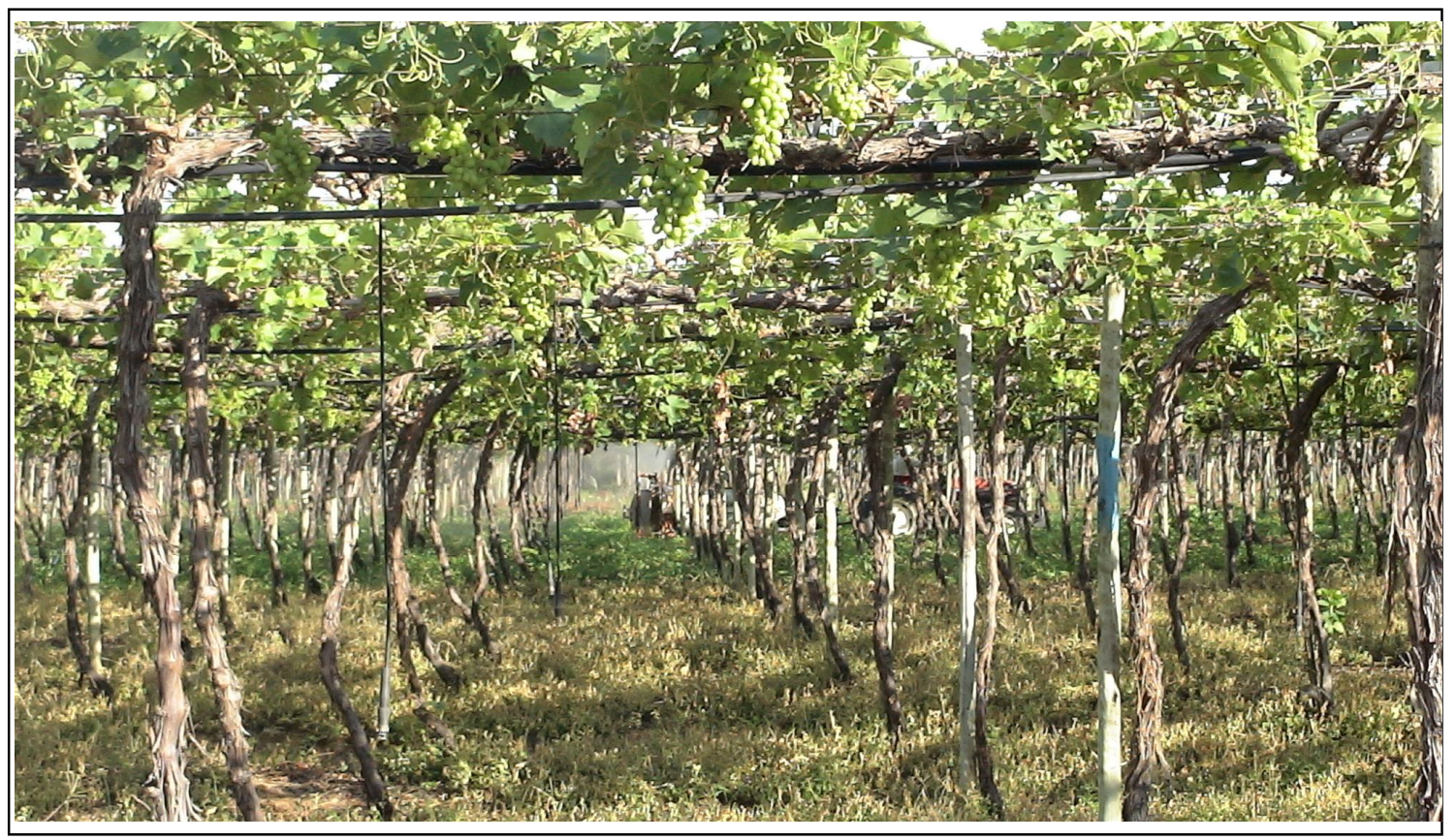

Figura 17. Parreiral de uvas, Petrolina/PE. Fonte: foto do autor, janeiro de 2013.

Essas empresas são detentoras de poder e as que mais se beneficiam da grande infraestrutura favorável ao capital, nacional e internacional, montada em tal região da bacia hidrográfica. A água abundante, dos reservatórios, em conjunto com o clima adequado e propício à produção agrícola tropical, formam o principal fator do complexo agrícola que se desenvolve ali. Pode-se dizer que isso configura o que há de mais importante para as estratégias do capital produtivo agrícola, pois os altos lucros resultarão com o mero

\footnotetext{
${ }^{9}$ BARBOSA, Josival Santos. Secretário Municipal de Agricultura de Juazeiro/BA. Organização espacial: Juazeiro/BA - Petrolina/PE. Entrevista (circulada via correio eletrônico) concedida a Regnaldo Gouveia dos Santos. Mensagem recebida por <regnaldogouveia@usp.br> em 1º de outubro de 2012. Declarou que "Em média, 7 hectares por pequeno produtor. [Já as empresas agrícolas ou agroindústrias têm] Em média 50 hectares, tem algumas empresas que detêm áreas maiores".
} 
investimento de dinheiro abundante dos capitalistas frente a todas essas vantagens, conforme os aspectos acima citados.

Como é possível perceber, através do uso da água, por meio de sistema de irrigação e do arranjo espacial, os fruticultores se beneficiam também com a energia produzida nas hidrelétricas ali instaladas. É com a força destas que grande parcela, senão a maior parte do parque industrial nordestino se mantém em atividade. Além disso, as residências, os setores públicos e privados do Nordeste são mantidos pela energia originária daqueles empreendimentos hidroelétricos que funcionam a partir do São Francisco, do qual o sertanejo ribeirinho depende para sobreviver. Contudo, sequer existe uma rede hidráulica eficiente para a dessedentação humana e animal, no mínimo, sendo sua instalação imprescindível em determinadas áreas povoadas de municípios ribeirinhos tanto em Sergipe, quanto em Alagoas.

Na Bahia, a jusante da Represa de Sobradinho, a situação dos habitantes desse espaço fluvial vai se apresentando cada vez mais difícil até o limite do sertão, próximo à foz.

Percebe-se que as circunscrições das áreas dos reservatórios ou barragens só podem ser entendidas como exceções, do ponto de vista capitalista, considerando o poder que esse sistema possui. Ou seja, para os ricos que ali se estabelecem, certamente é uma grande exceção, visto que a seca naqueles espaços não constitui problema por causa da abundância da água que combina com a estrutura instalada. O contrário ocorre com pessoas pobres, a maioria, que não foram beneficiadas através de políticas mitigadoras dos impactos socioambientais engendrados pela execução e atividade dos empreendimentos hidroelétricos instalados ao longo dessa bacia hidrográfica.

Na parcela do Baixo São Francisco, situada no sertão, além das outras partes do rio, há fatores característicos de organização socioespacial que conduzem às disparidades socioeconômicas da região Nordeste que destacam, igualmente, o aspecto de modernização. De um lado, estão os sertanejos que, apesar de terem seus territórios municipais banhados 
pelo rio, são atingidos diretamente pela falta de ações públicas efetivas para enfrentar as severas secas. Do outro lado, estão os ricos, quer sejam da zona rural ou urbana sertaneja até o agreste, quer sejam da zona urbana da planície litorânea, beneficiados pelas políticas desenvolvimentistas através de empreendimentos hidroelétricos.

Nessa porção da bacia hidrográfica, no espaço sertanejo, foi notável a possível relação entre o modo de ocupação e uso do solo de ancestrais e do povo ribeirinho do século XX. A maneira com que o homem desse século se relacionava com a natureza dava-se de uma forma que não era tão agressiva ao meio ambiente em relação ao presente, como bem observou Santos (2010).

Os ribeirinhos da zona rural tinham uma relação com o campo, de maneira que eles se utilizavam de instrumentos de trabalho, dentre outros, como o machado, a enxada e o arado, só que isso era bem mais notável até final do século passado. Eles faziam uso do machado para, entre outras atividades campestres, cortar a lenha, ora destinada às carvoarias, ora voltada ao uso doméstico. O transporte desse recurso do sertanejo era feito, geralmente, no lombo do jegue, em feixes ladeados na cangalha sobre o animal, até os seus destinos.

Uma técnica rudimentar utilizada por eles no preparo da terra para suas lavouras se completava com o arado de tração animal, mas isso era mais notável até o período acima citado do que hoje em dia. Tal técnica se confirmava através do modo como os ribeirinhos utilizavam o instrumento, de maneira que uns lavravam a terra com uma parelha de bois encangados, arrastando o arado, guiados por uma pessoa que o forçava contra o solo. Outros agiam da mesma forma, porém, ao invés de bois, era um jumento arreado que puxava o referido arado, às vezes eram dois jegues emparelhados que o arrastavam.

Essa variação entre o número de animais ocupados na atividade agrícola, naturalmente dependia do poder aquisitivo do lavrador. 
Por vezes, naquela época, observavam-se alguns realizando a lavragem da terra com enxada arrastada pelo jegue em pontos de solo menos compacto como nas áreas arenosas. $\mathrm{O}$ uso da força braçal com esse instrumento era mais frequente no passado, apesar de até hoje ainda se utilizar no tratamento das lavouras, limpando o mato (erva daninha) que tenta impedir o desenvolvimento dos legumes no inverno nordestino, isto é, o período de chuvas.

Assim, os ribeirinhos do sertão do Rio São Francisco, quer seja habitante da beira do fluxo fluvial, quer seja residente de lugar distante deste a algumas léguas, tinham de sobreviver a longos períodos de estiagem e a todas as dificuldades que enfrentavam, entre outras circunstâncias. Denota-se, portanto, que "O sertanejo é, antes de tudo, um forte." (CUNHA, 2000, p. 105). Um dos maiores símbolos de sua resistência é manter seu vínculo em um espaço tão desafiador a respeito de sua vida. Houve períodos de seca nessa região que marcaram a vida do sertanejo desde o início até meados do século XX. Os que estavam mais afastados do rio foram os que mais sofreram porque, enquanto seu rebanho morria de sede, eles peregrinavam caatinga adentro à procura de água. Quando encontravam, a léguas da residência, um tanque (depósito natural de águas nascentes) com pouca água, eles tinham de pedir permissão ao dono da terra para poder abastecer uma carga de água em jumento, para apenas a dessedentação humana. Caso contrário, passavam cerca de um dia andando a pé ou no jegue ou no carro de boi até o Rio São Francisco em busca d'água destinada aos afazeres domésticos e sua dessedentação. Enquanto isso, o gado bebia água salobra, inviável ao consumo humano, quando encontrada nos olhos d'água (nascentes). Tal prática no passado foi comum aos sertanejos situados na região da antiga Fazenda Ponta da Vaca, Povoado Lagoa do Rancho, município de Porto da Folha/SE.

Por um lado, considerando o contexto do início deste terceiro capítulo, que se diga, o sertanejo se desenvolveu até final do século passado, em termos, socioeconomicamente, submetido à resistência e ao limite natural (referente ao clima) e por vezes à injustiça social. 
Esta se confirma na falta de ações de políticas públicas, tanto que até hoje ainda são ausentes na região, do ponto de vista de uma implementação eficaz e efetiva. O fato de a parte sertaneja (distante do leito do rio) entrar em estado de calamidade pública por falta de água durante o período de estiagem, principalmente, em municípios banhados pelo caudaloso São Francisco, ratifica a assertiva acima. Os habitantes dessas áreas podiam e podem fazer uso do direito e poder que têm, democraticamente (participação de todos, ricos e pobres), irrigando tais áreas habitáveis, levando em conta todos os cuidados ambientais, de modo sustentável. No entanto, esse direito, já que o território em que esse povo está inserido também é banhado por tal rio, não está sendo reconhecido, pois que os gestores públicos competentes, representando o Estado, não implementam ações de políticas públicas capazes de o ratificarem, assim como uma irrigação que não cause danos ao meio ambiente.

Por outro lado, os habitantes da zona urbana até a região do agreste e, principalmente, os da planície litorânea são os mais beneficiados, que se diga, pelo uso do recurso hídrico do baixo curso como no lazer e através da produção de energia elétrica, de acordo com essa fonte. Em contrapartida ao direito do sertanejo ribeirinho, há muitos empreendedores da agroindústria explorando a água a qualquer custo, muitos destes que não nasceram e nem se criaram ali, tampouco são constituídos dos mesmos valores daquele povo que sabe lidar e conviver com o rio.

Pode-se dizer que tais produtores são oportunistas da estrutura moderna presente e vieram negar o modo de vida tradicional do povo ribeirinho que foi deslocado das margens naturais do rio para, contra seus valores socioculturais, dar lugar, por exemplo, ao lago da Usina Hidrelétrica (UHE) Xingó, entre outros reservatórios de hidrelétricas. Por fim, esses empreendimentos atendem, direta ou indiretamente, ao atual modelo de economia tão criticado por se apresentar, muitas vezes, "soberano" aos Estados que por vezes se mostram submetidos às regras do neoliberalismo. 
A justificativa de oportunismo se deve ao fato de tais empreendedores, sem identidades locais, aproveitarem a infraestrutura do lugar que já encontraram instalada pelo Estado e adequada a seus fins. Isso se refere ao desenvolvimento e escoamento da produção agrícola. Em razão disso, tais empreendedores passam a deter (no sentido de conservar em seu domínio) maiores poderes, uma vez que, ao se inserirem nesse espaço, já tinham importante concentração de capital, bem como os grandes empresários nacionais ou internacionais.

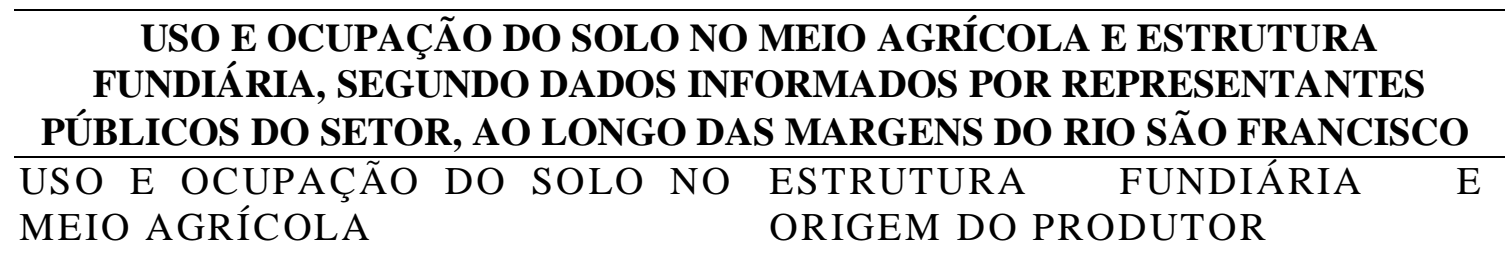

PRODUÇÃO DE SEMENTES, BASICAMENTE GRÃOS COMO MILHO, FEIJÃO, SOJA*

PRODUÇÃO DE FRUTAS COMO MANGA, UVA, COCO, GOIABA, ACEROLA, MARACUJÁ, MELÃO, ETC. $^{* *}$

IRRIGAÇÃO DE RIZICULTURA***

PRODUÇÃO DE FRUTAS COMO MANGA, COCO ANÃO, BANANA, MARACUJÁ, ABACAXI, MELANCIA, LIMÃO $\mathrm{O}^{* * *}$

MONOCULTURA DE CANA-DE-AÇÚCAR ${ }^{* * *}$
DOMÍNIO DE GRANDES PRODUTORES COMO EMPRESAS QUE NÃO SE RESTRINGEM AO LOCAL* \begin{tabular}{llllll}
\hline AS & SEMENTES & SÃO & PROCESSADAS & FORA & DO
\end{tabular} MUNICÍPIO*

$\overline{\text { A PRODUÇÃO ATENDE AOS NÍVEIS ESTADUAL E }}$ NACIONAL*

A IRRIGAÇÃO DA REPRESA DESTINA-SE SÓ PARA A AGRICULTURA EMPRESARIAL*

GRANDES PRODUTORES COMO EMPRESAS EXTRANGEIRAS OU DE OUTRAS PARTES DO BRASIL DETÊM, EM MÉDIA, 50 HECTARES POR PROPRIETÁRIO, SENDO QUE OUTRAS POSSUEM MAIORES ÁREAS DAS TERRAS IRRIGADAS ${ }^{* *}$

PEQUENOS PRODUTORES DETÊM EM MÉDIA 7 HECTARES (POR PROPRIETÁRIO) DAS TERRAS IRRIGADAS $^{* *}$

A PRODUÇÃO É ESCOADA PARA OS MERCADOS NACIONAL E INTERNACIONAL (EM MAIOR PROPORÇÃO) ${ }^{* *}$

LOTES PARA COLONOS (ARROZ) DO LUGAR ${ }^{* * *}$

LOTES EMPRESARIAIS PARA EXPORTAR FRUTAS (PRODUTORES DE VÁRIAS PARTES DO BRASIL) ${ }^{* * *}$

Quadro 01. Alguns aspectos do uso e ocupação do solo no meio agrícola e a estrutura fundiária ao longo das margens do Rio São Francisco.

Fonte: $\left(^{*}\right)$ Roberto Carlos Rodrigues, Secretário Municipal de Agricultura de Três Marias/MG. Entrevista concedida a Regnaldo Gouveia dos Santos, 02 de julho de 2012.

$\left({ }^{* *}\right)$ Josival Santos Barbosa, Secretário Municipal de Agricultura de Juazeiro/BA. Entrevista concedida a Regnaldo Gouveia dos Santos, 29 de junho de 2012.

$\left.{ }^{* * *}\right)$ José Eriberto Pinheiro Vieira, Chefe da Emdagro do município de Neópolis/SE. Entrevista concedida a Regnaldo Gouveia dos Santos, 08 de janeiro de 2013. 
Por imposição do empreendimento hidroelétrico, os ribeirinhos que foram obrigados a abandonar seu modo de desenvolvimento independente nas margens do rio passam a se sujeitar às condições dos referidos empreendedores. Daí por que estes negam o modo de vida tradicional de muitos daqueles que eram independentes, de modo que a maior parcela de sua lavoura era para seu sustento (subsistência), ao contrário do que se nota no quadro 01 anterior, no que se refere aos dias de hoje.

Ao analisar a referida ilustração (quadro 01), é possível notar que as condições de sobrevivência dos ribeirinhos, além de desfavoráveis ao desenvolvimento da agroindústria, se tornam cada vez mais precárias ante o modelo de produção (exportação) praticado nos perímetros irrigados, pois nem todos têm acesso à água para irrigar seu pedaço de terra, quando possuem.

Demonstra-se também um dos importantes fatores, assim como a existência e atividade das hidrelétricas, que contribuem com o discernimento da configuração socioespacial moderna, pela qual o espaço geográfico da Bacia São Francisco vem sofrendo. Observe (no quadro 01) que o predomínio da estrutura fundiária está em posse dos grandes produtores, como grupos empresariais da agroindústria, por vezes estrangeiros. Como se vê, o uso e ocupação do solo estão mais voltados para o cultivo de frutas e cana-de-açúcar, visando atender o mercado externo, do que para a agricultura alimentar básica, por exemplo: arroz, milho, feijão, mandioca.

Acredita-se que, na tomada de decisão pela instalação de um empreendimento como os hidroelétricos de grande porte, entre outros, está incluso direta ou indiretamente, o interesse do desenvolvimento agrícola baseado na irrigação. Não há como descartar que grandes empresas desse ramo estejam exclusas desse interesse, pois se percebe que existe a predominância de sua influência nas áreas banhadas pelos lagos de tais empreendimentos. Tal circunstância já tem sido cogitada a respeito da transposição do Rio São Francisco, que é 
também um grande empreendimento, conforme debates acompanhados que trataram desse tema.

É relevante frisar o que para Mota (2005, p. 95):

A situação dos Xocó não era diferente da dos demais trabalhadores ribeirinhos sem terra, já que a produção agrícola de Sergipe declinou sensivelmente a partir de 1974. A CODEVASF tinha iniciado, por aquela época, um plano de colonização e irrigação visando o plantio do arroz, plano este que não se mostrou capaz de gerar riqueza e paz social no campo.

Nessa concepção, percebe-se que o Estado não desenvolveu políticas de geração de renda eficazes para a população da região, constituída dos valores locais, principal alvo das ações de mitigação dos impactos socioambientais acarretados por causa dos empreendimentos hidroelétricos instalados. Razão pela qual, de uma forma ou de outra, fez-se notar que a renda continuou a se concentrar nas mãos dos proprietários de terras circunscritas aos reservatórios, importantes produtores de hortifrútis. Isso ocorreu e ocorre, entre outras maneiras, através de "estranhos" produtores da agroindústria, que passaram a adquirir ou a arrendar terras banhadas pelos reservatórios de empreendimentos hidroelétricos, desde o alto até o baixo curso do rio, por força do alto poder aquisitivo que eles detinham e detêm.

Por um lado, o Estado é responsável pela mitigação dos impactos detectados no Baixo São Francisco, pois a empresa empreendedora dos projetos de geração de energia em atividade, a Chesf, que é causa de tais impactos, é definida como Sociedade de Economia Mista, o que também responsabiliza a participação privada (pessoa jurídica) dessa empresa, neste caso.

Por outro lado, segundo a Constituição Federal (1989):

Art. 225 - Todos têm direito ao meio ambiente ecologicamente equilibrado, bem de uso comum do povo e essencial à sadia qualidade de vida, impondo-se ao Poder Público e à coletividade o dever de defendê-lo e preservá-lo para as presentes e futuras gerações.

$\S 1^{\circ}$. Para assegurar a efetividade desse direito, incumbe ao Poder Público:

I - preservar e restaurar os processos ecológicos essenciais e prover o manejo ecológico das espécies e ecossistemas;

[...]. 
Desse modo, observa-se que o Estado, mais uma vez, é responsabilizado ou o responsável pelo desenvolvimento de políticas mitigadoras dos impactos causados em função dos empreendimentos citados.

Assim, conforme as características anteriormente abordadas, a feição do moderno também está presente no baixo curso do rio, embora o entorno do Lago Xingó revele alguns aspectos dessa natureza, é o platô de Neópolis/SE, situado a jusante, que merece aqui ser destacado em tal sentido. Por essa razão, referida menção se trata de um projeto de agricultura irrigada que foi implementado pelo Estado de Sergipe, voltado para o setor empresarial, segundo representante institucional com a intenção de se exportar frutas, o que se comprova até hoje. Além de frutas como coco e banana, que são exportadas desse polo para outros Estados brasileiros (Bahia, Pernambuco, Alagoas), o limão é exportado para o exterior ${ }^{10}$.

Por fim, notou-se que, em contrapartida a essa infraestrutura, que detém mais de 7.000 hectares, as terras de várzea foram subdivididas em mais de 500 lotes para algumas famílias sobreviverem, a cargo de projetos da Companhia de Desenvolvimento dos Vales São Francisco e Parnaíba (Codevasf) ${ }^{11}$. O projeto visando o desenvolvimento voltado para os pequenos produtores de arroz passou a ser implementado entre as décadas de 1970 e 1980, pelo Governo Federal, coordenado pela Codevasf. Enquanto isso, o projeto voltado para atender aos empresários, por iniciativa do Estado de Sergipe, tem seu pico de desenvolvimento por volta da década de 1990.

Da análise da figura 18 (a seguir), é possível observar o canal de irrigação, parte da infraestrutura implementada pelo Estado para atender ao setor privado, resultando na tendência da organização espacial que vem ocorrendo. Na sequência, observa-se também a

${ }^{10}$ VIEIRA, José Eriberto Pinheiro, Chefe da Emdagro do município de Neópolis/SE. Entrevista concedida a Regnaldo Gouveia dos Santos. Neópolis/SE, 08 de janeiro de 2013. Informou: “[...] o limão vai pra Europa, vai pra Europa, [prejudicado]".

${ }^{11}$ VIEIRA, José Eriberto Pinheiro, Chefe da Emdagro do município de Neópolis/SE. Entrevista concedida a Regnaldo Gouveia dos Santos. Neópolis/SE, 08 de janeiro de 2013. Declarou que a área de várzea "foi subdivida em 513 lotes pra colonos, né? [...] Eh... Hoje, o Platô [de Neópolis/SE] desses 7.500 hectares, voltou metade pra cana-de-açúcar, pra um desestímulo de alguns empresários. A cana tá aí, ganhando o espaço. Quer dizer, tá voltando o que era há vinte anos atrás". 
estrutura do sistema agrícola de uma propriedade empresarial produtora de grama vegetal do tipo que é utilizado, principalmente, em campos de futebol.

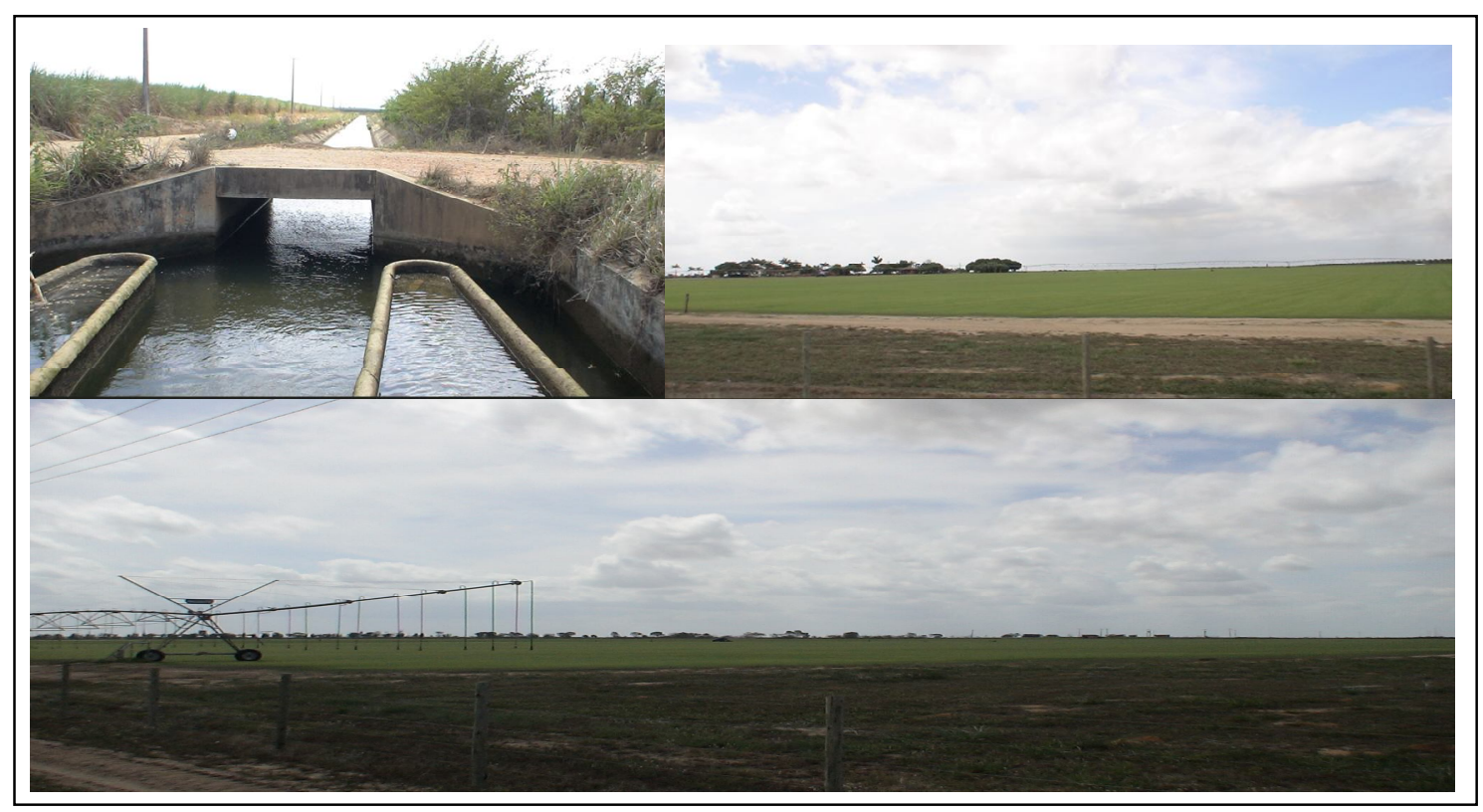

Figura 18. Organização espacial no Baixo São Francisco, platô de Neópolis/SE. Fonte: foto do autor, janeiro de 2013.

O fato é que, ao invés das políticas públicas serem aplicadas no setor público como em desenvolvimentos de programas sociais, assim como assistir os pequenos produtores da agricultura familiar, para suprirem as demandas internas, as ações do Estado se destinam ao setor privado, que atende seus diversos interesses, como a reprodução do capital privado. Faz-se necessário realizar tal crítica devido às queixas existentes de muitas pessoas que ainda sobrevivem desses projetos de irrigação do arroz no Baixo São Francisco, na região de Propriá/SE, por falta d'água no canal de irrigação. Episódio este que não é detectado no platô de Neópolis/SE, como se notou na figura 18, acima. E o pior de tudo: o uso da água do rio, que é de todos, ao invés de atender a todos, inclusive a necessidade dos mais pobres, atende a cerca de metade do grande projeto para irrigar a cana-de-açúcar da agroindústria. Veja que no lado esquerdo do canal de irrigação do grande projeto do platô, na figura 18, acima, existe uma extensão de monocultura canavieira, o que reforça a ratificação das assertivas acima. 
A política voltada para altos investimentos na produção do setor energético deixou marcas expressivas tanto sobre o espaço natural, quanto no social, conforme foram bem analisados, principalmente no baixo curso do rio, segundo Santos (2008). No que se refere ao meio ambiente, o rio se encontra num estado tão degradado que em determinados pontos, entre os Estados de Sergipe e Alagoas, os bancos de areia impossibilitados de serem carreados para o mar, por falta das cheias naturais, dão condições de pessoas alcançarem cerca da metade do leito natural a vau. Antes da existência da UHE - Xingó, essa façanha nunca foi possível, até porque a principal causa da falta de transferência desses bancos de areia para as praias marítimas tem sido o controle da vazão nos reservatórios das UHE(s), o que impede a ocorrência das cheias naturais cíclicas que carreavam os sedimentos até o Atlântico. Toda essa degradação ambiental reflete no espaço social, de maneira que as condições de vida dos ribeirinhos, na grande maioria, foram transformadas radicalmente e muitas vezes ficaram vulneráveis a situações calamitosas, o que também se constata no Baixo Nilo.

Segundo Sharaf el Din (1977) o período de inundação do Rio Nilo ocorria de agosto a novembro, apresentando o pico em setembro, e isso era notório até vésperas do barramento para o preenchimento do Lago Nasser. Esse fenômeno natural mantinha a forma do delta, mas de acordo com o autor, na frente desse espaço fluvial, as condições hidrográficas já foram seriamente afetadas.

Entre os impactos que o Nilo sofreu e, consequentemente, passaram a atingir os habitantes dependentes do rio, é importante apontar os da ação direta das pessoas e das indústrias presentes nas margens fluviais. No primeiro caso, os esgotos domésticos tornam-se causa dos impactos em função da falta de saneamento básico, substancialmente, sobre as áreas rurais, ao passo que no segundo, a falta de cumprimento do dever legal público é essencialmente responsável por impactos, ao deixarem de tratar a água escoada para o rio depois de utilizada em atividades diversas. 
Como a irrigação é notória em grande parte da bacia hidrográfica do Nilo, ao longo de suas margens os impactos ambientais se desencadearam também, através de reações químicas dispersas na água devido às praticas agrícolas, próximas do rio, que sofrem aplicações de fertilizantes e agrotóxicos. Esses impactos refletem diretamente na natureza, atingindo o ecossistema em que se encontra a população de peixes, sendo a população humana também afetada por tais impactos, ao se alimentar do peixe contaminado. Por sinal, de acordo com Couture e Eaton (2007), a concentração de poluentes como fósforo e azoto (nitrogênio) na água represada é causa de significativos danos à população de peixes, pois é comum ocorrer proliferação de algas no corpo d'água em tal condição. Certamente, as populações humanas que se abastecem dessa água, sem ser devidamente tratada, correm riscos de sofrer sérios danos à saúde.

A respeito da dinâmica fluvial de rios impactados por barragens, segundo Coelho (2008), pode-se observar que, no caso do Rio Nilo, a Barragem Alta Assuã foi causa de impactos ambientais notórios na zona deltaica do referido rio. Tais impactos foram detectados, de maneira que, de acordo com artigo escrito no "Journal of Coastal Research", conforme Fanos (1995), estudo desenvolvido por membros do Instituto de Pesquisa Costeira sobre a agressão/erosão do Nilo mostrou que a erosão aumentou no delta após a existência da Barragem Alta Assuã. Uma das causas desses impactos foi a retenção dos sedimentos no Lago Nasser, pois, com o barramento do rio, as águas ficam impossibilitadas de desempenhar o processo natural de carrear grandes volumes de matérias pesadas depositadas no lago ao longo do tempo.

O desequilíbrio presente no espaço fluvial passou a ser observado na natureza (no ecossistema). Ou seja, a ausência da grande quantidade de humos correspondente à renovação natural do solo é um fator que tende a deixá-lo bastante vulnerável quanto ao quesito da matéria orgânica necessária para o cultivo da terra. Nesse sentido, outro fator importante a ser 
destacado é que, de acordo com Sharaf el Din (1977), o processo de carreamento de sedimentos pelas águas do Nilo até a sua foz foi interrompido. O agravante é que essa carga de sedimentos era responsável por manter as duas penínsulas Roseta e Damietta, formadoras fundamentais do delta.

Os impactos ambientais que se percebem foram desencadeados devido à ação antrópica sobre o rio na altura do Lago Nasser. Em função de tal ação, é possível observar que a força natural das águas do Nilo, no baixo curso, a jusante de Alta Assuã, diminuiu e resultou, em contrapartida, na reação da força marítima contra o espaço da foz, assim como aconteceu no Baixo São Francisco, por causa da execução e operação de seus empreendimentos hidroelétricos ao longo de seu curso. Percebe-se, portanto, que esta força, por ser natural, se sobrepôs à atual e frágil força fluvial, tendo em vista a expressiva interferência humana detectada no seu leito.

Seria um tanto quanto injusto ou simplista deixar de citar ou de frisar que os impactos ambientais, depois de manifestados na natureza, podem ser causa de consequências para o próprio homem e quando isso se ratifica, resulta no impacto socioambiental. Significa dizer que, principalmente, os habitantes do Baixo Nilo sofreram graves consequências tanto em aspectos culturais, quanto sociais, entre outros danos. Nesse contexto, vale dizer que nem o povo nilótico, nem os turistas de qualquer parte do mundo contemporâneo terão o privilégio ou o prazer de contemplar a paisagem cultural dos resquícios do antigo Egito, na região da Núbia, submersa pelo Lago Nasser, que segundo Mello (1996) outrora foram contemplados por Dom Pedro II (Imperador do Brasil).

As assertivas acima corroboram os impactos desencadeados nas margens do Nilo e que a escala de alcance não se restringe ao local ou regional, mas também chegam a atingir o global. Apesar do salvamento arqueológico, ao resgatarem alguns templos e monumentos de áreas que foram alagadas, a contemplação da paisagem pré-histórica original, nesse contexto, 
está longe de se confirmar devido à realocação desses patrimônios históricos em locais que não são originais desses templos e monumentos. Ainda que o leito do rio volte a fluir naturalmente, sem interferência ao longo de seu curso, e com a realocação desses patrimônios históricos em seus pontos de origem, se torna inadequado afirmar que os valores dos aspectos naturais e culturais, bem como sua configuração paisagística, venham prevalecer ali, pois a sua originalidade deixou de assim ser devido à remoção.

Assim, da análise da pesquisa foi possível observar que o período entre as décadas de 1960 e 1970, quando o grande empreendimento Alta Assuã foi executado, marcou a história do Nilo e do Egito, pois os impactos socioambientais engendrados nesse espaço geográfico, em função da existência e operação da usina hidrelétrica, sinalizaram a mudança de tempo e espaço. O grande Lago Násser é responsável por manter o volume de água para a geração de energia a partir de tal empreendimento hidroelétrico, apesar de Biswas e Tortajada (2012) observarem que a energia gerada pela barragem, desde seu início, só pagou o custo total da construção da estrutura.

Noutras palavras, significa dizer que o tempo e o espaço dos impérios faraônicos foram deixados para trás de uma vez por todas. Seus vestígios possíveis de serem observados na maneira do homem nilótico se relacionar com o rio, fazendo uso de suas águas e do solo de suas margens, arraigados nos valores ancestrais, se confirmaram até meados do século XX, época que antecede a execução e funcionamento do empreendimento hidroelétrico de Alta Assuã.

Tais vestígios eram representados no modo da relação existente entre o homem e a natureza da bacia hidrográfica do Rio Nilo, de maneira que, na era faraônica, em determinado rito, uma das principais recitações, conforme Pasa e Discovery Communications (2002), era: “- não desviei o leito do rio”. Isso ocorria em benefício do rio e, consequentemente, daquele povo que dependia de sua natureza plena para sobreviver. 
Já no caso do rio brasileiro, considerando a água como fundamental para o desenvolvimento humano do país, como um todo, em especial a região dos municípios banhados pelo São Francisco, por que o Estado não investe efetivamente e de forma eficiente em abastecimento hídrico voltado para os mais pobres da zona rural, que geralmente vivem em estado de calamidade pública devido à escassez de água? Entre outros fatores políticos, o caso da indústria da seca, assim como determinadas medidas políticas mal sucedidas oriundas de políticos insensatos, que visam perpetuar seu status de poder, assim visto como péssimo e antidemocrático; diante de tal condição, essa pode ser uma das respostas para tal incógnita. Além disso, já que os pontos rurais, onde se encontram os mais pobres, não apresentam estrutura atrativa ao capital, pode ser outra causa da ausência do Estado, uma vez que este tem se apresentado promissor ao interesse do sistema capitalista, o que nega a condição do camponês tradicional. Nesse sentido, é importante frisar, o modelo ideológico neoliberal que se apresenta como uma inovação do capitalismo vem dando forma ao espaço da Bacia Sãofranciscana, com destaque para Juazeiro/BA e Petrolina/PE, entre outros lugares. Igualmente, esse sistema vem impulsionando novas configurações socioespaciais no Baixo Nilo, a partir do empreendimento de Alta Assuã, conforme foi tratado ao longo do texto.

Mediante essa concepção vale ressaltar, também, um dos pontos do Rio São Francisco que estão com sua organização socioespacial mais vulnerável a maiores adversidades resultantes da ação antrópica, o seu baixo curso, ou seja, toda a extensão a jusante de Xingó. Um dos últimos agravantes que pode se confirmar é uma futura mineração de ferro, que virá explorar a margem direita do rio, na circunscrição da geo-histórica Serra da Tabanga, entre os municípios Gararu/SE e Nossa Senhora de Lourdes/SE, entre outros. Segundo Souza (2010, p. ?), “[...] serão investidos US\$ 40 milhões nos Projetos 'Sergipe Ferro', em uma área entre os Municípios de Gararu, Canhoba, e Nossa Senhora de Lourdes, e 'Catingueiras', em Canindé do São Francisco". 
Com relação ao Rio Nilo, a partir da Barragem Alta Assuã (Lago Nasser), é notório que a causa dos impactos socioambientais engendrados pela ação humana ao executar e explorar o grande empreendimento para, entre outras funções, gerar energia hidrelétrica, não pode ser atribuída aos países a montante do rio. O que justifica isso é a situação geográfica do grande lago por estar, em sua maior parte, dentro do Egito, e os danos mais significativos afetarem principalmente esse país, pois, no contexto do presente estudo, ficou explícito que as civilizações do resto do mundo podem ser atingidas por tais impactos, em termos arqueológicos. Ou seja, corroboram-se as assertivas acima, conforme anteriormente foi abordado sobre perdas da originalidade de paisagem pré-histórica, bem como monumentos removidos de seus pontos originais para darem lugar ao Lago Nasser. O fato é que, qualquer turista de qualquer parte do mundo, ao se dirigir para referido lugar com o objetivo de apreciar tais monumentos não os contemplará com as mesmas condições que lá se encontravam no passado, antes da existência do lago.

Foi possível observar que o período que se estendeu entre as décadas de 1960 e 1970 ratifica aspectos em comum aos dois espaços fluviais, pois conforme representado, no rio africano, foi executado o grande empreendimento hidroelétrico Alta Assuã, à medida que eram empreendidos outros no Brasil, como Três Marias, Moxotó e Sobradinho, sendo que Xingó se confirmou na década de 1990. Por essa razão, desencadearam-se os impactos e a partir destes foram realizadas análises que deram o contexto do presente estudo, fator fundamental do conceito da Airehg.

Assim, alcançou-se o objetivo proposto para este capítulo, de modo que a interpretação da Airehg, por meio dos impactos socioambientais confirmados no espaço geográfico do São Francisco e do Nilo, principalmente, nos baixos cursos, veio contribuir com o conceito de referida área. 
Uma das hipóteses secundárias confirmou-se através da análise dos impactos comuns aos dois rios, e representados como variáveis da paisagem cultural, sobretudo na referida parte dos cursos fluviais, por aqueles constituírem a citada área de influência real.

Nesse sentido, o que define a dimensão espacial destacada acima é o alcance do impacto ambiental ou socioambiental, neste caso, sua delimitação é possível através da detecção de tais impactos e, para isso, é necessário analisar cada situação mediante a correlação existente entre os seres vivos e o meio ambiente. 


\section{CONCLUSÃO}

Tendo em vista que cada capítulo desenvolvido se contextualizou segundo os objetivos da presente pesquisa, em princípio propostos, foram alcançados de acordo com suas especificidades. Para tanto, ora foram enfatizadas as entrevistas realizadas, a revisão bibliográfica, a análise documental, ora as visitas de campo, dentre outros modos, representadas por meio de registros fotográficos, análise de dados interpretados e também representados nos mapas, gráficos, entre outros meios em que foram verificadas as hipóteses. Estas, por sua vez, foram ratificadas de acordo com os objetivos alcançados conforme foram arrematados no contexto a seguir.

Com tudo isso, considerando a abordagem do primeiro capítulo que se investiu em definir o tema em epígrafe, contextualizando-o no campo da Geografia e que está imbricado na área de previsão de impactos, os critérios elencados foram definidos em primeiro lugar, de maneira descritiva e em segundo lugar, de forma argumentativa, gerando a discussão que veio revelar os resultados de tal abordagem. No primeiro caso, sobre a descrição, destacaram-se os aspectos físicos do espaço geográfico, divisores de água, o rio principal e seus afluentes, a vegetação e o clima. No segundo caso, as possibilidades da relação do homem com a natureza aprestaram-se como suporte de argumentação, bem como a discussão para o entendimento do impacto socioambiental que se ratificou levando em conta também os aspectos físicos do espaço geográfico.

Posto isto, a discussão surge quando os animais passaram a aparecer nesse cenário e, principalmente, o homem por ter a capacidade de pensar e de imperar com sua ação sobre o meio ambiente.

Assim, observou-se que a ocorrência da inter-relação existente entre os seres vivos e o meio ambiente da bacia hidrográfica, de um modo, extrapola os limites desta e, de outro, se 
mantém dentro de sua abrangência. Por meio da correlação que há entre os seres vivos formando o ecossistema, foi possível notar a transcendência do limite da bacia hidrográfica através da migração de espécies animais entre uma bacia e outra, no entorno dos divisores de água. Além de também serem observadas as mesmas características climáticas e fitogeográficas entre a Bacia São Francisco e a do Rio Sergipe, por exemplo. Os fatores físicos apresentam-se semelhantes na Serra da Canastra, entre as bacias do Rio São Francisco e do Rio Grande. Já a fauna aquática, manteve-se limitada por ter seu habitat natural; o fluxo fluvial também se limita aos divisores da rede hidrográfica, mas com única abertura na foz, em termos de água superficial. Com isso, percebe-se que tais divisores só delimitam as águas superficiais e a forma do relevo da bacia hidrográfica observada na paisagem, porém, sua importância não se descarta por causa de seu valor delimitador em termos de espaço físico.

A ação humana surge como causa do impacto ambiental que, na maioria das vezes, se volta contra o próprio homem, resultando, deste modo, no denominado impacto socioambiental. Desse pondo de vista, parte a relevante discussão espacial que, ao longo do texto, os critérios elencados deram base para alcançar os objetivos propostos e afirmar a hipótese levantada, conforme se apresentam adiante.

Quando se refere a esse tipo de impacto, inevitavelmente, o fator dimensão espacial tem de entrar em discussão, pois, em tese, é esse fator que, sobretudo, contempla o tema que está sendo tratado. Para melhor clareza da dimensão espacial, importa refletir sobre a escala, pois, dessa maneira, é possível compreender até onde o fenômeno alcança.

Além disso, a "Escala é um atributo fundamental das pesquisas geográficas. Entretanto, a utilização deste termo requer algum cuidado, pois existem para ele diferentes conotações." (QUEIROZ FILHO e DE BIASI, 2011, p. 173). Nessa concepção, cabe frisar que os significados de escala cartográfica, de análise e do fenômeno estão contemplados ao longo do presente estudo. O primeiro corresponde à relação existente entre a dimensão real do objeto 
observado e sua representação no mapa; o segundo, à análise de grandeza do fenômeno observado em termos de local, regional e global. O sentido de escala do fenômeno, por estar ligado ao tema em epígrafe é mais enfático, neste caso.

De acordo com Queiroz Filho e De Biasi (2011, p. 173), “A escala dos fenômenos caracteriza as dimensões da sua ocorrência sobre a superfície terrestre [...]".

Por isso, é relevante considerar não só a consequência que a natureza sofre, o impacto ambiental, mas também os efeitos deste sobre a sociedade, o impacto socioambiental. Ou seja, é preciso levar em conta o fenômeno como um todo, manifestado dentro ou fora da bacia hidrográfica do rio interferido.

Por um lado, o critério divisor de águas da variável característica física do espaço geográfico (que também é critério de definição da Airehg) mostrou-se como limítrofe da região hidrográfica do rio principal, deixando de cumprir sua função apenas na foz. Apesar disso, as possibilidades de correlações entre os seres vivos e o meio ambiente transcendem esse divisor, o que vem ratificar o conceito do tema em epígrafe. Contudo, isso não refuta o conceito essencial do divisor de águas, em termos de aspecto físico, pois o mesmo conceito é fundamental para desvencilhar qualquer pensamento que o considere como limite da restrita área de influência de empreendimentos hidroelétricos alocados na mesma bacia hidrográfica. Ou seja, referida área tem de se ater às possibilidades de correlação que há entre os seres vivos e o meio ambiente, neste caso, mas não se limitar apenas à bacia hidrográfica do rio interferido, conforme foi, reiteradamente, afirmado.

Por outro lado, a análise da variável uso da água, do critério dimensão do impacto socioambiental $^{*}$ (também variável, pois sua definição não se limita a apenas uma característica) revelou a extensão que referido impacto pode alcançar. Isso foi possível através da relação que existe entre o homem e a natureza, por exemplo, como qualquer vínculo

(*) Dimensão espacial possível de ser mensurada em relação às consequências que a sociedade sofreu, em função do impacto ambiental percebido no meio ambiente. 
cultural, bem como o consumo de água, a partir do rio, praticado pelas pessoas que vivem dentro ou fora da bacia hidrográfica.

Neste caso, não há uma delimitação física como o divisor de águas da bacia hidrográfica do rio interferido, mas tudo parte do ponto de interferência e se esbarra onde o impacto socioambiental foi ou pode ser detectado (considerando os termos da previsão de impactos conforme foram abordados). Nesse contexto, entre outras circunstâncias, destacam-se os costumes de vida do povo ribeirinho em relação ao rio, além da vulnerabilidade ao impacto socioambiental daquele povo e da população abastecida pela água, habitante de dentro ou de fora da bacia hidrográfica do rio interferido.

\section{UMA DAS MANEIRAS DE OPERACIONALIZAR A ÁREA DE INFLUÊNCIA DO} EMPREENDIMENTO HIDROELÉTRICO NO EIA/RIMA

\begin{tabular}{|c|c|}
\hline SSEGURARAM QUE* & $\begin{array}{lllll}\text { QUANTO À } & \text { DIMENSÃO } & \text { QUE } & \text { O }\end{array}$ \\
\hline & IMPACTO ALCANÇA, AFIRMARAM** \\
\hline $\begin{array}{lll}\mathrm{O} & \text { EIA/RIMA } & \text { CONSIDERE }\end{array}$ & $\begin{array}{lllll}\text { NÃO } & \text { SE } & \text { RESTRINGE } & \text { ÀS } & \text { ÁREAS }\end{array}$ \\
\hline VALORES DO POVO TRADICIONAL & INFLUÊNCIA DIRETA E INDIRETA \\
\hline SEJAM PROPOSTAS S & PROGRAMAS \\
\hline ONFLITOS EXISTENTES E & DESENVOLVIDOS DE SOBRADINHO À \\
\hline POVO ATINGIDO PELOS IMPACTOS & FOZ DO RIO SÃO FRANCISCO \\
\hline O EMPREENDIMENTO & $\begin{array}{llll}\text { NA } & \text { RENOVACÃO DO } & \text { LICENCIMENTO, }\end{array}$ \\
\hline$\overline{\mathrm{DA} O}$, AO POVO ATINGIDO PELOS & QUANDO UM PROGRAMA É SOLICITADO \\
\hline IMPACTOS, CONDIÇÕES DE VIDA & PELO IBAMA É ATENDIDO PELO \\
\hline SEMELHANTES & EMPREENDEDOR \\
\hline NTECEDERAM À EXISTÊNCIA DO & NÃO PODE DIZER QUE AS ÁREAS DE \\
\hline MPREEN & $\begin{array}{l}\text { INFLUENCIA DIRETA E INDIRETA SÃO } \\
\text { SEMELHANTES PARA TODOS OS TIPOS } \\
\text { DE EMPREENDIMENTOS }\end{array}$ \\
\hline
\end{tabular}

Quadro 02. Uma breve representação de alguns fatores que contribuem com o entendimento de como a Airehg pode ser operacionalizada.

Um dos meios para mensurar a dimensão dos impactos é executar o EIA, e este deve ser fiscalizado juntamente com os empreendimentos em atividade, por órgãos públicos institucionais, pois a credibilidade de teor do referido documento depende do grupo que deve

(*) Fonte: Paulo Roberto Mendes Belchior, Gerente de Departamento do Meio Ambiente da Companhia Hidroelétrica do São Francisco (Chesf), Recife/PE. Elvidio Landim, Gerente da Divisão do Meio Ambiente de Geração da Chesf, Recife/PE. Entrevista concedida a Regnaldo Gouveia dos Santos, 10 de janeiro de 2014. 
se debruçar na análise de cada caso das mais diversas situações que abrangem o tema do estudo da previsão de impactos. Por isso, é relevante examinar todos os possíveis pontos de vínculo do rio interferido com as mais diversas circunstâncias, sejam da ordem física, cultural, econômica ou social, porque, através desse meio, será possível perceber o grau de efeito que determinado lugar ou pessoa possa vir sofrer em função do impacto ambiental detectado no rio. Neste caso, é importante destacar o aspecto da dimensão que o impacto pode alcançar, ou seja, não se restringe a um ponto qualquer, mas tem de abarcar até onde o impacto foi detectado. Nessa concepção, cabe chamar a atenção para o que observou o representante da ONG Canoa de Tolda ${ }^{12}$.

Desse modo, o que consta no quadro $n^{\circ} 02$ dá noção de como medir a dimensão que o impacto pode alcançar. Assim, foi possível contextualizar, sobretudo, a partir da análise da pesquisa, como acontecem e qual é o alcance dos impactos ambientais e socioambientais estudados, neste caso.

Agora, quanto ao exame do quadro $\left(\mathrm{n}^{\circ} 02\right)$ a que se refere, levando em conta a realidade em que se encontram o rio e as condições de sobrevivência do povo a partir do cultivo de arroz, que em vários casos já não existe (devido à extinção do ciclo de cheias naturais e à ausência de políticas, pelo menos, de mitigação dos impactos), resta afirmar que suas assertivas são duvidosas, isto é, as afirmações que compõem o referido quadro.

Além dos procedimentos legais que já existem e precisa fazê-los valer, é necessário também acrescentar a tais procedimentos o preceito revelado no presente estudo.

Assim, se, de fato, tudo o que consta no quadro $\mathrm{n}^{\circ}$ 02, embasado nas afirmações dos representantes da Chesf, fosse corroborado, levando em conta o que revelou a presente pesquisa, traz mais um meio de operacionalização da Airehg junto aos procedimentos legais.

12 Carlos Eduardo Ribeiro Júnior. Presidente da ONG Canoa de Tolda. Entrevista concedida a Regnaldo Gouveia dos Santos. Brejo Grande /SE, 03 de janeiro de 2014. Afirmou: “- Então, o problema, por exemplo, o problema do São Francisco é problema de Aracaju, que tem sessenta por cento da sua água tirando daqui. Então, se amanhã não tiver mais água aqui no São Francisco, Aracaju vai ficar sem água, as pessoas...". 
Quanto à análise alcançada no presente feito, que contemplou a abordagem da paisagem natural, observando o processo de correlação que há entre a fauna e seu ecossistema, foi possível perceber que, em determinada situação, o meio aquático se apresenta delimitando o habitat dos peixes, entre outras espécies. Já o meio ambiente fora da água não apresentou a mesma condição de limite, pois pássaros migratórios transcendem a área da bacia hidrográfica. Não só a avifauna composta por esses, mas outras espécies animais que se movimentam entre os divisores de água também se alimentam e se reproduzem nessa região, abrangendo pontos de duas bacias hidrográficas.

Também, do ponto de vista da paisagem natural, observou-se que a mesma característica do bioma cerrado ocorre por entre as cabeceiras do Rio São Francisco e de afluentes do Rio Grande, que é contribuinte do Rio Paraná. O clima semiárido, que abrange inúmeras outras bacias hidrográficas, transcende os divisores de água do Baixo São Francisco.

Tal análise não se restringe à abordagem anterior, pois a paisagem cultural também foi interpretada ao mensurar a dimensão que o impacto socioambiental pode alcançar, tanto que aqui se trata de previsão de impactos.

A compreensão da dimensão que referido impacto pôde alcançar, culminou com a execução e operação do último empreendimento hidroelétrico que foi instalado ao longo do Rio São Francisco. Foi por causa da observação dos impactos ambientais e socioambientais, constatados fora da área de influência do Empreendimento Xingó, que se passou a perceber quão inviável é adotar essa área como foi tomada pelo empreendedor.

Da análise da pesquisa, observou-se que, ao longo do tempo, as vazões registradas nos empreendimentos hidroelétricos que estão situados, respectivamente, em Sobradinho/BA e Canindé de São Francisco/SE, ratificam a diminuição do volume que foi registrado no baixo curso fluvial, conforme é possível conferi-lo no gráfico (fig. 19) a seguir. Neste caso, percebeu-se que o Lago Sobradinho, por ser um dos maiores do mundo, pode barrar um 
volume muito maior em relação ao de Xingó. Ao comparar os reservatórios, o gráfico dá evidências de que o volume do último, na disposição apresentada, representa cerca de 2/6 daquele. Percebe-se que, na primeira década de 2000, toda a quantidade de água registrada em Sobradinho não passou pelo último empreendimento hidroelétrico que fica a jusante, o que comprova o uso de grande volume de água entre o reservatório baiano e o de Xingó ${ }^{13}$. A afirmação do segundo entrevistado reforça a ideia do primeiro sobre o uso múltiplo do Rio São Francisco, conforme é possível conferir em nota ${ }^{14}$.

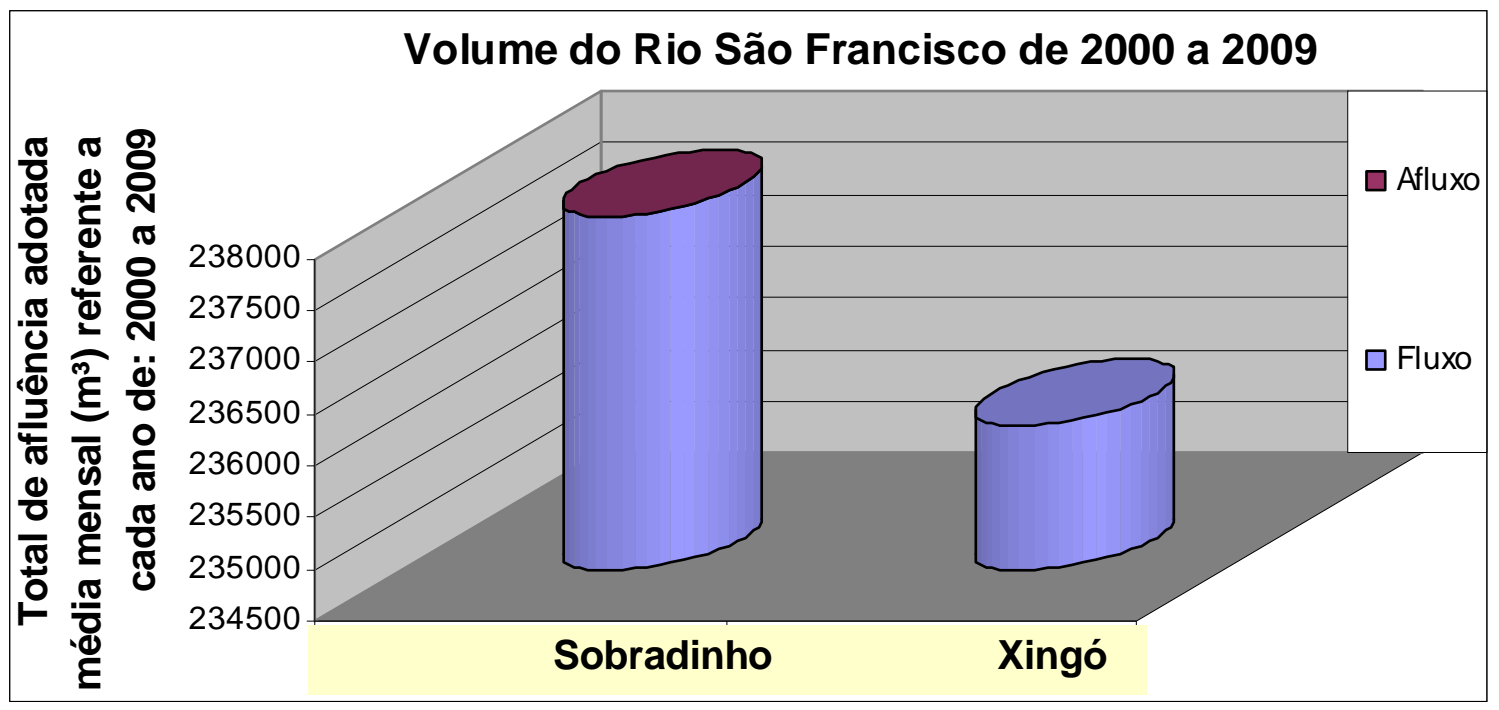

Figura 19. Compara o volume do rio através do afluxo (entrada) e fluxo (saída) dos dois lagos.

Denota-se que essa prática de vazão não ocorreu pela primeira vez em 2014, de acordo com a pesquisa, pois em 2008, enquanto Sobradinho recebeu $2900 \mathrm{~m}^{3} / \mathrm{s}$., média referente ao mês de fevereiro, no mesmo mês Xingó registrou uma vazão média de 1124 m³/s. Como se não bastasse, referido mês se enquadra no período de cheias do rio, ou melhor, quando este possuía seu aspecto natural.

\footnotetext{
${ }^{13}$ RIBEIRO JÚNIOR, Carlos Eduardo. Presidente da Organização Não Governamental - Canoa de Tolda. Entrevista concedida a Regnaldo Gouveia dos Santos. Brejo Grande /SE, 03 de janeiro de 2014. Declara: "Então, hoje o uso múltiplo do São Francisco não existe, nós temos um rio que atende hegemonicamente o sistema hidrelétrico".

${ }^{14}$ LANDIM, Elvidio. Gerente de Divisão do Meio Ambiente de Geração da Companhia Hidro Elétrica São Francisco (Chesf). Entrevista concedida a Regnaldo Gouveia dos Santos. Recife/PE, 10 de janeiro de 2014. Afirmou: "[...] em função de um estudo da ONS (Operador Nacional do Sistema Elétrico), foi apontado pela ONS. Foi solicitado que a Chesf, ela pedisse ao órgão ambiental uma redução de vazão. [...] e ele emitiu uma autorização especial pra a gente operar abaixo de mil e trezentos, né? Até mil e cem $\left(\mathrm{m}^{3} / \mathrm{s}\right.$.)".
} 
Assim, tudo isso convergiu para a causa do impacto ambiental, a alteração da qualidade da água, que foi reclamada pelos ribeirinhos, no baixo curso do rio e, por sua vez, se correlaciona com o fator de diminuição da população de peixes, entre outras consequências. As implicações que a qualidade da água vem sofrendo nos reservatórios, em função dos fatores conforme já foram abordados, expõem o meio ambiente ao impacto ambiental, ao passo que as pessoas vinculadas ao rio, de alguma forma, estão susceptíveis aos impactos socioambientais.

Observou-se que há pessoas residindo além da bacia hidrográfica, mas elas estão vinculadas ao Rio São Francisco, de forma significativa, pois dependem diretamente de sua água para sobreviver. Desse modo, considerando a poluição que se concentra nos reservatórios, originária das áreas urbanas modernas, inclusive da metrópole mineira, além da agroindústria, entre outros meios de produção agrícola, como sistemas irrigados, aquelas pessoas também se encontram vulneráveis aos impactos socioambientais. Disso não se pode duvidar, pois é sabido que o tratamento de água para abastecimento ainda não é capaz de eliminar determinados poluentes como os interferentes endócrinos (poluição hormonal).

Com a análise que se realizou ao longo das abordagens já feitas, verificando importantes dados e informações com base na revisão da literatura levantada e da pesquisa de campo, foi possível observar que o contexto do presente estudo se ratificou no campo da Geografia, contemplando a área de previsão de impactos. Igualmente, revelou o conceito da Área de Influência Real de Empreendimentos Hidroelétricos do ponto de vista da Geografia através da abordagem da paisagem, configuração espacial capaz de representar as possibilidades da ação humana na natureza. Outros objetivos foram alcançados, à medida que os critérios utilizados como variáveis da paisagem foram especificados, assim como as características físicas do espaço geográfico, e o conceito do impacto socioambiental, de modo que, em conjunto, todos definiram o tema em epígrafe. 
Os critérios foram especificados seguindo a necessidade do entendimento da organização tanto do espaço, quanto do povo que o envolve. A partir desse momento e através da análise da paisagem, passou-se a discernir como partes do espaço geográfico vieram corroborar a concepção da Airehg. Desse modo, foram definidos os critérios abordados ao longo do texto.

Além de tudo, esses objetivos foram reforçados a partir do que se revelou na ratificação das hipóteses verificadas no segundo e terceiro capítulos.

Esses objetivos que foram alcançados vieram consolidar a base do presente estudo, consubstancialmente, afirmando a hipótese que questionou como a Airehg se configura no espaço geográfico, levando em conta as paisagens naturais e culturais vinculadas a um rio interferido por empreendimento hidroelétrico. Referentemente a essa hipótese, chegou-se à conclusão de que, em última instância, é através das possibilidades de correlações existentes entre as características culturais e a interação dos seres vivos com o meio ambiente que referida área se configura no espaço geográfico.

Assim, notou-se que, ao discutir a questão ambiental, foi necessário pensar sobre a relação do homem no espaço considerando o tempo, sem deixar de ponderar sobre tudo o que os envolve, isto é, refletir a esse respeito de maneira equitativa e equilibrada. Daí por que se referir a uma concepção geo-histórica, pois nesse contexto, os fatos se dão no espaço ao longo do tempo, tendo o homem como sujeito, sentido que resulta na sustentação do termo socioespacial. Neste caso, à medida que o tempo passa, a ação antrópica é a referência da transformação do espaço.

Foi possível concluir também, a partir da abordagem do segundo capítulo, que a complexidade do problema de ajuste no EIA incide na relação existente entre o EIA/Rima apresentado pelo empreendedor, o que emana da Lei de Política Nacional do Meio Ambiente a esse respeito e a Área de Influência Real de Empreendimentos Hidroelétricos do ponto de 
vista da Geografia. Esse objetivo foi alcançado a partir da revisão bibliográfica abordada no segundo capítulo, sem deixar de considerar os resultados que foram revelados no primeiro e terceiro capítulos. Ou seja, para se chegar a tal conclusão, foram levados em conta o aporte legal e os conceitos científicos contextualizados em cada proposição capitulada no presente trabalho.

Nesse sentido, em termos de uma concepção geo-histórica, observou-se que o instrumento de política ambiental brasileiro, EIA/Rima, bem como o da UHE-Xingó, entre outros, tem conteúdo confuso ou, pelo menos, deixa a desejar quando comparado com o que emana da supracitada lei.

Da análise da pesquisa, denotou-se que a abordagem sobre o contexto geo-histórico a respeito do Estudo de Impacto Ambiental revelou a origem desse instrumento e como o mesmo foi institucionalizado no Brasil.

Tal análise girou em torno da interpretação temporal e espacial, de modo que esta representou os lugares em que o EIA foi institucionalizado e aquela a disposição do tempo pelo qual este fato se confirmou.

Nesse contexto, notou-se que esse instrumento de política ambiental surgiu como tal nos Estados Unidos da América (EUA), em 1969, quando também se corroborou no país, o aporte legal que, em português, significa algo como a Lei de Política Nacional do Meio Ambiente (Nepa, sigla original).

A década de 1970 marcou um tempo de conscientização ambiental na antiga Alemanha Ocidental (República Federal da Alemanha), o que lhe fez criar a Lei da UVP, em português é Estudo do Impacto Ambiental ou Análise do Impacto Ambiental, porém, sendo regulamentada só em 1991, depois da reunificação da Alemanha.

Já o período que marcou a atual Rússia, nesse sentido, foi a década de 1980 com a criação do Comitê Estadual para a Proteção da Natureza, em 1987. A palavra russa que 
corresponde à sigla Owos pode ser traduzida por Avaliação da Ação sobre o Meio Ambiente, ou seja, algo como o EIA/Rima.

Enfim, a institucionalização desse documento ocorreu no Brasil, em 1986, com a Resolução Conama nº 01/86, regulamentada pela Lei nº 6.938/81, conforme já foi afirmado.

Foi possível observar também que o EIA/Rima brasileiro teve, indiretamente, influência norte-americana. Afinal, uma das instituições financeiras dos grandes projetos, dos quais se exige esse documento, é o Banco Mundial, sediado nos EUA.

Observou-se que, por influências internacionais, assim como do Banco Mundial, a Avaliação de Impacto Ambiental (AIA) foi instituída no Brasil como um dos instrumentos da Lpnma. Por isso, neste caso, o EIA/Rima passou a ser exigido pelos órgãos ambientais competentes em licenciamento ambiental das hidrelétricas com potencial acima de $10 \mathrm{MW}$, por exemplo.

Desse modo, notou-se que o instrumento de política ambiental, nos termos institucionais da Lpnma, tem cumprido o parâmetro legal. Todavia, o referido documento apresentado pelo empreendedor, por ser passível de críticas, conforme foram fundamentadas, não pode representar, exatamente, o mesmo valor. Pode-se entender que o EIA/Rima instituído pelas Resoluções submetidas à Lei 6.938/81, abaixo ressaltadas, representa as diretrizes legais, mas seu texto, após a elaboração do documento custeado pelo empreendedor, mostra-se vulnerável aos interesses deste. Tal vulnerabilidade se revela a partir das críticas que foram abordadas anteriormente. Assim, também se expressa a necessidade da Lpnma passar por um ajuste, pois é possível afirmar que a $\mathrm{AI}$, dentro dos parâmetros dessa lei, é pouco abrangente quando comparada à Airehg.

De acordo com a abordagem realizada, à proporção que o objetivo do segundo capítulo foi alcançado, suas hipóteses se ratificaram. 
Com relação ao objetivo, revelou-se que a falta de consideração da Airehg por parte do EIA/Rima (cujo projeto o empreendedor é responsável por suas custas) se configura, de fato, em um problema de ajuste na Lei de Política Nacional do Meio Ambiente, no caso brasileiro, por exemplo. A análise bibliográfica e documental do aporte legal e o EIA/Rima serviram de fundamento para o alcance desse objetivo.

Ao verificar as hipóteses, de acordo com a análise da pesquisa, foi possível afirmá-las conforme seguem.

A Resolução Conama $n^{\circ}$ 01/86 determina que o EIA/Rima considere a bacia hidrográfica ao delimitar a Área de Influência do empreendimento hidroelétrico com potencial acima de 10 MW. Todavia, há caso comprovado no Rio São Francisco em que grande parte de seu espaço geográfico não foi levada em conta no referido documento, apesar de sofrer impacto ambiental. Assim, confirmou-se que o descompasso existente a partir do EIA/Rima em relação à interpretação desse elemento espacial, do ponto de vista da Geografia, ocorre por causa da falta de consideração da Airehg. Além disso, percebe-se que a Lpnma também precisa ser ajustada de acordo com a tese afirmada no presente estudo, no sentido de amparar a Airehg, fator crucial que se destina a um caminho nos rumos do tão almejado desenvolvimento sustentável. Esses foram alguns dos avanços da pesquisa, alcançados pelo objetivo proposto no segundo capítulo. Espera-se, com isso, que passe a ocorrer o envolvimento dos meios social, econômico e ambiental, de modo que o primeiro procure sempre preservar o último e o segundo leve em conta os valores de natureza plena dos outros dois com senso de corresponsabilidade.

Foi possível comprovar que, tendo em vista o processo geo-histórico do EIA/Rima, a consideração da Área de Influência Real de Empreendimentos Hidroelétricos do ponto de vista da Geografia por parte desse documento implica em resolver o problema de ajuste. Isto é, quando o EIA/Rima, por parte dos empreendedores, considerar a Airehg, de fato, referido 
problema passa a ser resolvido. Nesse sentido, é relevante que a Lpnma passe por um ajuste a partir do qual venha reconhecer a Airehg e seja constituído aporte legal como Resolução Conama tratando do tema.

Percebe-se que, em termos de ações políticas, tudo isso está na alçada do Estado por vias da competência de seus órgãos institucionais. O presente estudo busca contribuir em revelar um dos meios para se perfazer o caminho que pode alcançar o tão sonhado desenvolvimento sustentável.

Foi possível notar também que referido problema de ajuste legal tem relação com a evolução do tempo e da técnica, pois há vários meios de ocorrência do impacto ambiental ou socioambiental que estão ligados a tal evolução ao conduzir a água a um determinado destino através de rede hidráulica, entre outros meios. Neste caso, é possível dar referência à interrupção temporária do fornecimento de água ou à sua poluição, pois aquela era captada no passado por força humana e animal e mais tarde em redes de curtas distâncias, enquanto que hoje em dia o uso desse elemento natural transcende a bacia hidrográfica do rio provedor. Por essas e outras razões, faz-se necessário estar sempre pensando na Área de Influência Real de Empreendimentos Hidroelétricos do ponto de vista da Geografia, visando à preservação socioambiental.

Com a abordagem do terceiro capítulo, alcançou-se um dos objetivos do presente estudo, em pleno século XXI, que foi comparar alguns aspectos físicos e naturais, geo-históricos e socioculturais do espaço geográfico, principalmente, nos baixos cursos dos rios São Francisco e Nilo, visando à caracterização de critérios utilizados para contextualizar o cerne deste estudo. O presente objetivo foi alcançado a partir da revisão bibliográfica com a abordagem do terceiro capítulo e a análise das paisagens natural e cultural, levando em conta os dados e informações levantados na pesquisa de campo. 
Desse modo, foi possível concluir, após ponderar sobre todo o contexto acima explanado, entre outras abordagens, assim como a reflexão sobre os aspectos semelhantes e comuns em relação aos dois rios comparados, que a presente pesquisa representou a concepção do conceito da Airehg por meio do caso estudado.

Nesse sentido, é importante destacar que os aspectos semelhantes concernentes aos rios são as características físicas do espaço geográfico, ora limitando as bacias hidrográficas, ora transcendendo-as. Os divisores de água correspondem ao limite de tal espaço, enquanto que os fenômenos da natureza como o clima, entre outros aspectos, possuem a condicionante transcendental sobre referidos elementos delimitadores.

Já os aspectos comuns, esses correspondem à correlação existente entre os seres vivos e o meio ambiente, pois foram observados ao longo do espaço geográfico em que os rios estão situados. Foi analisando as variáveis da paisagem cultural, isto é, os impactos ambientais e socioambientais revelados no processo da citada correlação, que se notou algo em comum entre os baixos cursos fluviais. Por essa razão, é fundamental citar duas situações: a primeira dá referência aos impactos ambientais limitados aos divisores de água, mas que transcendem a área de influência defendida nos EIA/Rima(s) dos empreendimentos hidroelétricos por atingirem até as fozes de ambos os rios. A segunda diz respeito aos impactos socioambientais por transcenderem os limítrofes hidrográficos de acordo com as possíveis relações entre os seres vivos e os rios, com destaque para o habitante de fora da bacia e que usa a sua água, principalmente, para sua dessedentação.

Ao diferenciar o aspecto comum do aspecto semelhante, elementos de análise do Rio São Francisco em relação ao Nilo, entre outros aspectos da natureza, as espécies de vegetação da família cactácea encontradas em habitats naturais das bacias hidrográficas de ambos os rios são consideradas como um dos aspectos semelhantes. Isto é, ao que se sabe, não foram introduzidas em tais espaços pela mão do homem, mas são originais dos ambientes em que se 
situam em função das também semelhantes características climáticas observadas em referidos espaços geográficos. Noutros termos, a formação dessas associações vegetais, em tais espaços, tem a influência do clima como principal justificativa, isto é, um fator natural. Evidencia-se, portanto, que essa circunstância natural é diferente de casos em que há o transplante de uma espécie vegetal que não é nativa de determinado habitat natural. $\mathrm{O}$ fato de o arroz Oriza Sativa existir no Brasil é, então, um aspecto comum, visto que o cereal é nativo da Ásia. A mesma espécie existente nas distintas e distantes situações geográficas se deve à intervenção humana ao transportá-la de um lugar para o outro.

Outro exemplo de aspectos que há em comum entre o São Francisco e o Nilo, a respeito da cultura dos ribeirinhos desses rios, destacam-se dois animais por terem origem no espaço geográfico do rio africano e terem sido introduzidos no do rio brasileiro, a tilápia do Nilo e o jumento (ou jegue, como é conhecido). O primeiro era muito numeroso nas águas do São Francisco e de seus afluentes, no baixo curso, sendo de grande importância para o ribeirinho que sobreviveu dependendo desse espaço enquanto existiu o ciclo de cheias naturais. $\mathrm{O}$ segundo teve participação fundamental no desenvolvimento desse povo, visto que era com seu auxílio, na lida da terra, que os alimentos eram obtidos a partir das lavouras, e a condução da produção dessas para suas residências, entre outras serventias que o animal significava.

Deduz-se, portanto, que o aspecto semelhante se dá em razão da natureza por si só, enquanto que o comum existe em função da ação humana sobre a natureza.

Cabe afirmar que, diante de todos os elementos em comum conforme foram mencionados anteriormente, e todos os aspectos semelhantes existentes, as principais nascentes que contribuem com o fluxo dos leitos principais partem de pontos distintos, e distantes uns dos outros, em relação aos formadores das duas bacias hidrográficas comparadas. É importante esclarecer que essa distinção se dá em termos, tanto que os extremos de suas nascentes afloram no hemisfério Sul em relação à linha do Equador. 
Com relação ao rio brasileiro, se por um lado, foi possível notar que há uma ideologia neoliberal, representada na arrojada infraestrutura anexada à implementação dos empreendimentos hidroelétricos, por outro, é crível que a mesma ideologia esteja atrelada ao caso da transposição do Rio São Francisco.

Assim, também se pôde observar que dois fatores cruciais tornam a abordagem do tema da "transposição", relevante para o desfecho do presente estudo: a dimensão que a água do rio alcançará através dos canais e o volume d'água a ser captado para atender toda a área do projeto.

O primeiro fator reflete na abrangência da área de influência dos empreendimentos hidroelétricos que estão a montante dos pontos de captação, enquanto que o segundo implica no agravamento dos impactos já estudados no baixo curso do rio.

Ficou claro que tais empreendimentos são causa das disparidades socioespaciais observadas ao longo das margens dos rios São Francisco e Nilo. Isso está evidente através da paisagem cultural, com destaque para o lazer (nas segundas residências) e a estrutura representada na capitalização do campo, além do vultoso desenvolvimento das sedes municipais em que se situam os empreendimentos. Em contrapartida, essas vantagens particulares também são causa dos impactos ambientais detectados no espaço geográfico dos rios e que, por sua vez, engendram os impactos socioambientais que podem ser notáveis além da bacia hidrográfica dos rios principais.

Em termos de geopolítica, observou-se que os impactos socioambientais engendrados no Rio Nilo alcançaram escala internacional, à proporção que os originados no São Francisco atingiram a escala interestadual e, da maneira como ocorreram, transcenderam as duas bacias hidrográficas.

Tais impactos apresentaram-se com maior expressão no baixo curso dos dois rios, muito embora os ribeirinhos dessa parte fluvial não representassem agressão ao seu meio ambiente, 
de maneira significativa, conforme se comprovou por meio da sua relação com os rios no período que antecedeu a execução das usinas hidrelétricas.

Os referidos impactos ambientais e socioambientais também têm relação direta com a existência dos perímetros irrigados e a presença de malhas urbanas, pois passaram a se desenvolver por causa dos empreendimentos hidroelétricos e destinam seus resíduos aos rios. O fato de os reservatórios sofrerem tal poluição ocasiona um aumento do impacto ambiental devido à água represada. Após a passagem desta, todos os reservatórios fluviais a jusante e até os que se destinam ao abastecimento público municipal, inclusive da zona urbana, ficam sujeitos aos mesmos impactos capazes de atingir toda a população que se abastece dos rios.

A frase, Rio São Francisco - o Nilo brasileiro, não se justifica apenas pela resistência natural do rio representada através da análise da paisagem natural, mas também conforme foram interpretados os aspectos da paisagem cultural, bem como se configurou a relação do ribeirinho com o espaço fluvial. Dois reservatórios foram relevantes para a equiparação desses rios, Xingó e Nasser, localizados em pontos estratégicos dos baixos cursos, de modo que Xingó está cerca de 200 km da foz e Alta Assuã 1.000 km em relação a esse ponto do Nilo.

Da análise da pesquisa observou-se que, nas suas fozes, ocorre algo em comum, a desconfiguração por causa dos impactos ambientais engendrados a partir da existência e operação dos empreendimentos hidroelétricos. Nesse sentido, ao comparar as próximas imagens (figura 20), correspondentes a períodos diferentes, inclusive ao de conclusão das obras do Lago Nasser (1971), e dos dias atuais, percebe-se que houve uma mudança no traçado do canal deltaico que banha a península Roseta, pertencente ao Rio Nilo.

A mudança a que se refere é o encurtamento do curso do rio, na sua foz. A redução do volume fluvial através do controle da vazão na barragem de Alta Assuã é uma das principais causas desse fato. 


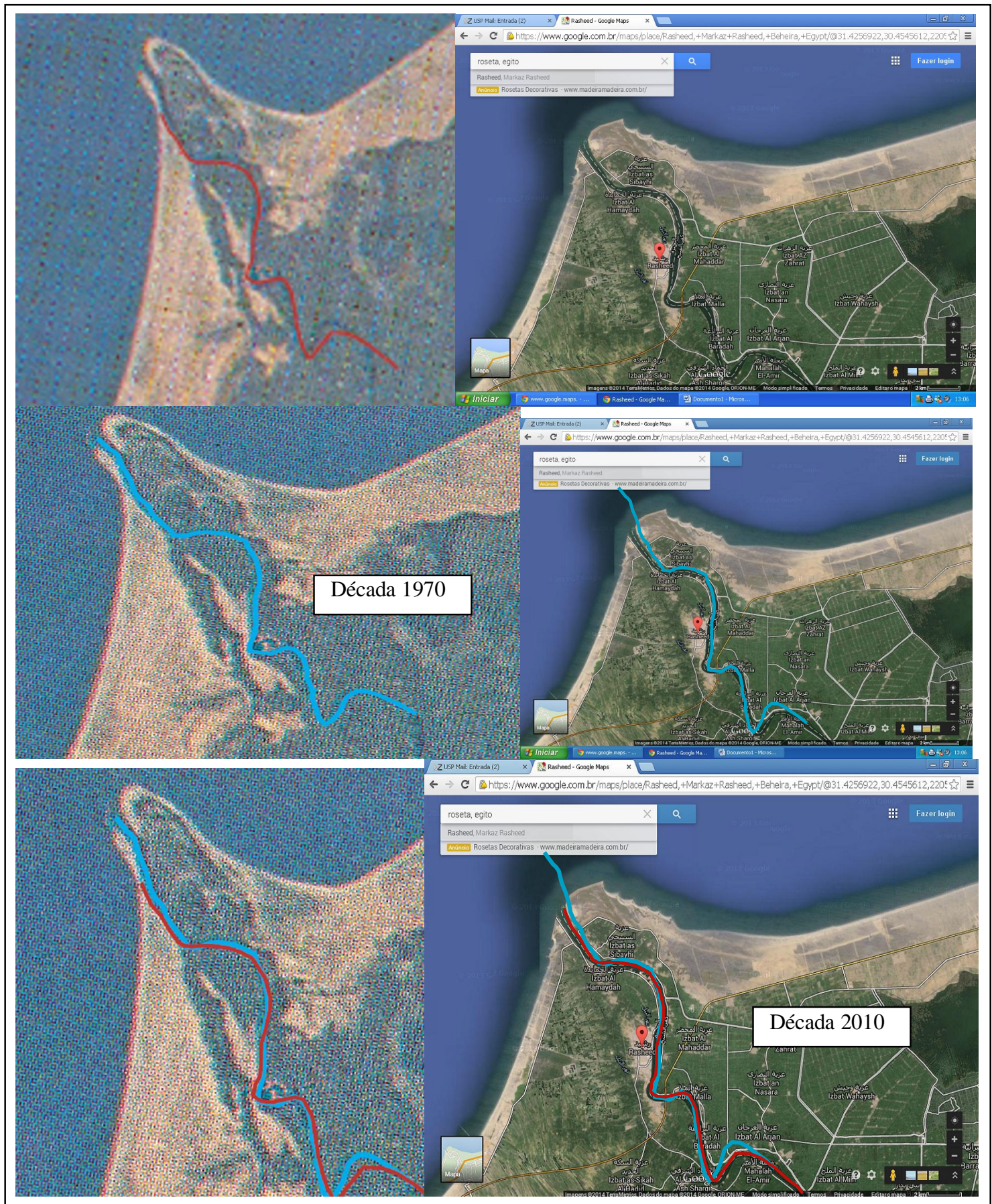

Figura 20. Representação da alteração da configuração espacial da Península Roseta situada no Delta do Nilo, Egito. Fonte: Fotografia aérea do início da década de 1970. REYER, Georges. Nilo. 1974. Imagem de satélite de 2014. Google maps, acesso em outubro de 2014.

Observando as imagens dispostas na figura 20, a linha vermelha que corresponde ao curso atual do rio foi traçada a partir da imagem de satélite, enquanto que a azul representa o leito original do rio antes dos impactos ambientais serem detectados e, para realizar essa comparação, foi considerada a escala da imagem de satélite. É possível observar o recuo da 
faixa costeira, na zona onde o rio deságua conforme representação das imagens confrontadas

(na figura 20), ao notar a diferença das extensões do curso fluvial e da planície na foz.

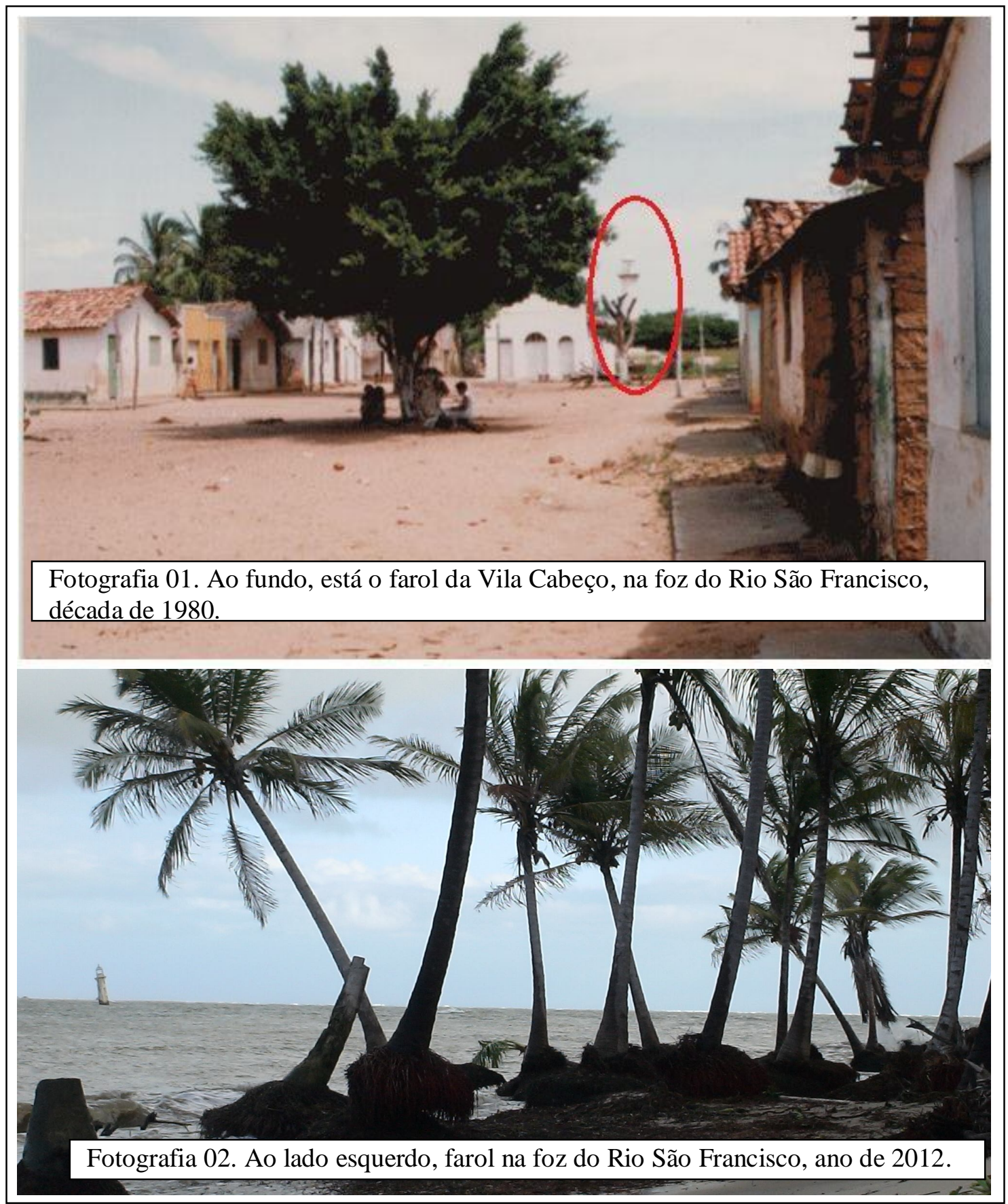

Figura 21. Representação da transformação do espaço geográfico na foz do Rio São Francisco. Fonte: fotografia 01. Tribuna da Praia, acesso em dezembro de 2014. Fotografia 02. Foto do autor, julho de 2012.

Como se pode perceber na figura 21 , nada menos grave aconteceu no caso do rio brasileiro, pois até um povoado que existia na região da sua foz foi extinto pela força 
marítima que se sobrepõe à correnteza do rio por causa da ação humana interveniente ao longo de seu leito, a montante.

Ao confrontar as fotografias da referida figura 21, considerando o contexto das abordagens anteriores a respeito dos impactos que o Rio São Francisco sofreu no seu baixo curso, ratificam-se as assertivas acima.

Observando a fotografia 01 (fig. 21), confrontada anteriormente, é possível notar o farol em condições adequadas e em terra firme, o qual era utilizado como orientação marítima enquanto existiu a Vila Cabeço, município de Brejo Grande-SE. Já na fotografia 02 (fig. 21), vê-se que da configuração espacial do povoado, do qual o referido farol fazia parte, só restou o resquício deste tombado pela força marítima que causa o afogamento da foz do Rio São Francisco.

Ao verificar a hipótese que confirmou a maneira como os espaços geográficos dos baixos cursos São Francisco e Nilo revelaram variáveis que constituem a Airehg, foi possível observar que, por um lado, os aspectos físicos e naturais como o clima e a vegetação transcendem a área da bacia hidrográfica, exceto os divisores de água (delimitadores da bacia). Por outro lado, os impactos ambientais e socioambientais definem o contexto da área de influência real de acordo com a dimensão espacial que os impactos se desencadearam ou podem se desencadear, sejam atingindo o espaço natural ou a sociedade.

A Área de Influência Real de Empreendimentos Hidroelétricos do ponto de vista da Geografia é a dimensão espacial, representada nas paisagens natural e cultural, sujeita a impactos ambientais ou socioambientais, independentemente de se limitar à bacia hidrográfica ou transcendê-la. Dito de outro modo, a Airehg é a forma espacial de cada parte da paisagem em que se denotam consequências sobre o meio ambiente por causa da ação humana na execução e operação de empreendimentos hidroelétricos, e sobre o meio social, quando o próprio homem sofre consequências em função do impacto ambiental. Ou seja, cada lugar 
onde os impactos se revelaram a partir de queixas da população local ou regional, ou está sujeito aos mesmos segundo EIA/Rima bem elaborado, dá o suporte da concepção de até onde o impacto pode alcançar. A condicionante, neste caso, é o uso da água conforme o presente estudo, mas noutros casos é necessário realizar estudo sério e comprometido com os valores humanos, e não somente com os lucros que dado empreendimento possa render, deixando os referidos valores em segundo plano, de modo voluntário ou involuntariamente.

Posto isto, foi alcançado o objetivo proposto a conceituar a Área de Influência Real de Empreendimentos Hidroelétricos do Ponto de Vista da Geografia, interpretando-a a partir das características físicas do espaço geográfico e do impacto socioambiental, embasando-se na análise da paisagem e considerando, portanto, em geral, alguns aspectos semelhantes notáveis nas bacias hidrográficas do São Francisco e do Nilo, enfatizando seus baixos cursos.

Quanto à sua operacionalidade, a Airehg deve ser levada em conta pelo EIA/Rima conforme foi contextualizada. Isto é, através do EIA/Rima, cada ponto em que se detectou impacto ambiental ou socioambiental, ou esteja sujeito a tal situação, direta ou indiretamente, tem de ser considerado como área de influência do empreendimento instalado, causa de tais consequências. Em outros termos, que todas as políticas de correção dos impactos sejam desenvolvidas, alcançando a todos que foram afetados pelos referidos impactos dentro e fora da bacia hidrográfica.

Agora, como tais políticas devem ser operacionalizadas, cabe a execução de um novo estudo em busca de tal direcionamento, além da responsabilidade do Estado por meio de sues órgãos diretores e fiscalizadores. Como já foi afirmado anteriormente, cada caso é um caso, isto é, a operacionalidade da Airehg depende da realização do EIA/Rima, que tem de considerar referida área de influência em relação à pretensão do empreendimento, desde que este instrumento de política ambiental tenha lisura. No contrário, a credibilidade de tal instrumento se torna duvidosa, pois o desastre ambiental configurado nas condições em que se 
encontra o Baixo São Francisco por causa de sua baixa vazão, cerca de 1.200 m³/s contra os $13.000 \mathrm{~m}^{3} / \mathrm{s}$ quando o rio corria naturalmente, justifica essas preocupações quanto a tais procedimentos.

Observou-se que enquanto a transformação socioespacial marcada pelo aspecto moderno se confirmou, paulatinamente, do alto ao baixo curso da Bacia São Francisco, este aspecto também foi notável no Baixo Nilo, diferente do resto de seu curso fluvial. Neste caso, a execução e operação dos empreendimentos hidroelétricos apresentam-se como um dos fatores, senão o principal propulsor desse fenômeno, engendrado a partir da ação humana no espaço geográfico de ambos os rios. Por causa da geração da energia, a água foi represada e disponibilizando, assim, cobiçados recursos energético e hídrico para o desenvolvimento agroindustrial presente hoje em dia nos referidos espaços fluviais.

Outro fator que não pode deixar de ser destacado, mas observado apenas no Rio São Francisco, é o projeto em execução da transposição de suas águas para outras bacias. Isso também acontece valendo-se da estrutura daqueles empreendimentos, tanto que os canais dos eixos Leste e Norte partem de pontos que contêm água represada, o que não poderia ser diferente, isto é, dificilmente ou nunca transfeririam determinado volume sem ter tal garantia. Da análise da pesquisa, evidenciaram-se dúvidas quanto à finalidade da transposição, conferidas, entre outros documentos, como entrevistas de representantes vinculados a órgãos públicos, mediante o que está proposto no EIA/Rima e o que vem sendo posto em prática. Assim, tudo indica que as margens de tais canais venham se configurar, num futuro próximo, como as regiões com características agroindustriais levantadas ao longo das margens do Vale São Francisco.

Em função da transformação socioespacial assinalada pelo aspecto moderno, de modo que, através da tecnologia, vem expandindo a relação de determinados pontos (dos rios) com diversos outros, a Airehg também se ratifica no espaço interativo dos fatores representados. 
Exemplo claro, neste caso, são as redes hidráulicas, por partirem de um rio principal ou de seus afluentes, para abastecer áreas distantes de tal rio, o que é diferente e mais eficiente em relação ao procedimento utilizado por meio dos diques nilóticos, na Pré-História.

Com relação à Bacia Hidrográfica São Francisco houve um fato novo que, por sinal, chama a atenção para a concepção do tema em epígrafe, ocorreu a transcendência da bacia hidrográfica através do uso de suas águas pelo povo habitante de outras bacias hidrográficas.

Com tudo isso, é certo afirmar que os elementos semelhantes e comuns aos rios Nilo e São Francisco, aqui realçados, são relevantes para a sociedade presente, entre outros fins, ponderar sobre experiências notáveis desde o passado, no intuito de se buscar meios para alcançar o tão sonhado desenvolvimento sustentável.

Assim, observou-se que a análise feita a respeito dos aspectos comuns e semelhantes em relação aos rios São Francisco e Nilo foi relevante, no caso estudado, para contextualizar o tema em epígrafe. Tais aspectos representaram-se nas paisagens cultural e natural, respectivamente, sendo que esta se referiu aos fatores naturais e aquela à existência e operação dos empreendimentos hidroelétricos dos dois rios, com destaque para Xingó e Alta Assuã, além da inter-relação existente entre os seres vivos e a natureza.

Igualmente, foi importante discutir a concepção de espaço pela qual se contextualizaram a definição e conceito do tema da presente pesquisa a partir da eleição dos critérios e variáveis condizentes.

Para que não ficasse lacuna referente ao contexto do cerne do presente estudo, foi abordada a questão existente entre o EIA/Rima, a Lpnma e a Airehg. A respeito de tal questão, surgiu a tese que se buscou defender incansavelmente ao longo do presente estudo, através da verificação das hipóteses que ratificaram respostas fundamentais quanto aos objetivos propostos e que foram alcançados. 


\section{REFERÊNCIAS BIBLIOGRÁFICAS ${ }^{15}$}

AB'SÁBER, Aziz Nacib. Relevo, Estrutura e Rede Hidrográfica do Brasil. Boletim Geográfico. Rio de Janeiro, v. 14, n. 132, p. 225-228, [s.n.] 1956. [s.n.] 1958.

A Geomorfologia no Brasil. Notícia Geomorfológica. Campinas, n. 02, p. 1-18,

Política de Meio Ambiente. In: Política de Meio Ambiente e Aproveitamento do Potencial Hidrelétrico Brasileiro, 1991, Rio de Janeiro. Anais dos Seminários Temáticos. Cadernos do Plano 2015, 2. Eletrobrás, 1991. p. 43-54.

O Homem dos Terraços de Xingó. São Cristóvão: Universidade Federal de Sergipe, 1997. 07 p. (Relatório de visita e pesquisas na área de Xingó, doc. no 06. Projeto Arqueológico Xingó).

A Porção semi-árida do São Francisco: é preciso compreender a natureza do rio para debater a transposição. Scientific American, Brasil, p. [s.n.], [s.n.], [200-].

Os Domínios de Natureza no Brasil: potencialidades paisagísticas. $2^{\mathrm{a}}$ edição. São Paulo: Ateliê Editorial, 2003. 160 p.

Espaço Total em uma Visão Multiecológica: mosaico inclui observações geográficas cruzadas com fatos ecológicos diversos. Observatório: Revista Cientific American Brasil. São Paulo, v. 02, n. 21, p. 98, [s.n.] 2004.

Topografia, paisagem e ecologia: é indispensável levar em conta a história do relevo e os seres vivos que o povoam. Observatório: Revista Cientific American Brasil. São Paulo, v. 3, n. 32, p. 98, jan. 2005.

Bases conceptuais e papel do conhecimento na previsão de impactos. In: AB'SÁBER, Aziz Nacib; MÜLLER-PLANTENBERG, Clarita (Orgs.). Previsão de impactos. $2^{a}$ edição. São Paulo: Edusp, 2006. p. 27-49.

Raso da Catarina: semi-árido com condições únicas de preservação da biodiversidade da caatinga. Scientific American, Brasil, p. 94, junho, 2006.

AB'SÁBER, Aziz Nacib \& MÜLlER-PLANTENBERG, Clarita (Orgs.). Previsão de impactos. $2^{a}$ edição. São Paulo: Edusp, 2006. 573 p.

ADORNO, Teodor W. Sobre Sujeito e Objeto. Revista Geocities, Paris, ano [s.n.], fascículo [s.n.], p. 01-16, junho, 1969.

ALVES FILHO, João. Transposição das Águas do São Francisco: agressão à natureza x solução ecológica. Maceió: Edições Catavento, 2000. 192 p.

\footnotetext{
${ }^{15}$ De acordo com:

ASSOCIAÇÃO BRASILEIRA DE NORMAS TÉCNICAS. NBR 6023: informação e documentação: referências: elaboração. Rio de Janeiro, 2002.
} 
AGÊNCIA NACIONAL DE ÁGUAS - ANA. Plano Decenal de Recursos Hídricos da Bacia Hidrográfica do Rio São Francisco: Diagnóstico da Bacia e Cenários de Desenvolvimento. Brasília: [s.n.], 2004. 234 p.

ANDRADE, Manuel Correia de. A Terra e o Homem do Nordeste: contribuição ao estudo da questão agrária no Nordeste. $7^{\mathrm{a}}$ edição. São Paulo: Editora Cortez, 2004. 318 p.

AZEVEDO, Aroldo de (Org.). Brasil: a terra e o homem. $2^{a}$ edição revista. São Paulo: Companhia Editora Nacional, 1972. 625 p.

BARBOSA. Josival Santos. Secretário Municipal de Agricultura de Juazeiro/BA. Organização espacial: Juazeiro/BA - Petrolina/PE [mensagem pessoal]. Mensagem recebida por<regnaldogouveia@usp.br> em 01 de outubro de 2012.

BARROS, Maêlda de Lacerda. A Função Hegemônica Globalizada do Sistema de Formas Normativas no Processo de Mercadificação Socioambiental no Polo de Fruticultura Irrigada Petrolina-PE / Juazeiro-BA. In: SÁ, Alcindo José de; FARIAS, Paulo Sérgio Cunha; ALBANO, Gleydson Pinheiro. Milton Santos e o universo (uno e diverso) brasileiro. Recife: Ed. Universitária da Ufpe, 2009. p. 217-236.

BECHMANN, Arnim; HARTLIK, Joachim. Sistemas de Informação Especializada: O Estudo de Impacto Ambiental. Tradução de Andrea Cristina Bianchi Alves. In: AB'SÁBER, Aziz Nacib \& MÜllER-PLANTENBERG, Clarita (Orgs.). Previsão de impactos. $2^{a}$ edição. São Paulo: Edusp, 2006. p. 497-522.

BELCHIOR, Paulo Roberto Mendes (Gerente de Departamento do Meio Ambiente da Companhia Hidro Elétrica São Francisco (Chesf)). Entrevista concedida a Regnaldo Gouveia dos Santos. Recife, 10 de janeiro de 2014.

BERQUE, Augustin. Paisagem-Marca, Paisagem-Matriz: Elementos da Problemática para uma Geografia Cultural. In: CORRÊA, Roberto Lobato; ROSENDAHL, Zeny (Orgs.). Paisagem, tempo e cultura. Rio de Janeiro: Eduerj, 1998. p. 84-91.

BISWAS, Asit K; TORTAJADA, Cecilia. Impacts of the High Aswan Dam. In: TORTAJADA, Cecilia; ALTINBILEK, Dogan; BISWAS, Asit K. Impacts of Large Dams: A Global Assessment. Berlim: Editora Springer, 2012. p. 379-395. (Water Resources Development and Management).

BLOCK, Paul J. Mittigating the Effects of Hydrological Variability in Ethiopia. New York: Columbia University, 2008. Disponível em: <http://www.waterandfood.org>. Disponível em: <http://www.janusonline.pt/popups2011 2012/2011 20122 4.pdf>. Acesso em 16 de outubro de 2013.

BOBEK, Hans; SCHMITHÜSEN, Josef. A Paisagem e o Sistema Lógico da Geografia. Tradução de Gabrielle Corrêa de Paiva. In: CORREAA, Roberto Lobato; ROSENDAHL, Zeny (Orgs.). Paisagem, tempo e cultura. Rio de Janeiro: Eduerj, 1998. p. 75-83.

BRASIL. Lei 6.938, de 31 de agosto de 1981. Dispõe sobre a Política Nacional de Meio Ambiente, seus fins e mecanismos de formulação e aplicação, e dá outras providências. Diário Oficial da União, Brasília, DF, 02 set. 1981. 
BRASIL. Conselho Nacional do Meio Ambiente - Instituto Brasileiro do Meio Ambiente e dos Recursos Naturais Renováveis (Conama/Ibama). Para efeito desta Resolução considera-se impacto ambiental... Resolução Conama, nº 01, 23 de janeiro de 1986. Resoluções, Brasília, fevereiro de 1986.

Conselho Nacional do Meio Ambiente - Instituto Brasileiro do Meio Ambiente e dos Recursos Naturais Renováveis (Conama/Ibama). Determinar à sua Secretaria Executiva, que... Resolução Conama, nº 23, 18 de setembro de 1986. Resoluções, Brasília, setembro de 1986.

Conselho Nacional do Meio Ambiente - Instituto Brasileiro do Meio Ambiente e dos Recursos Naturais Renováveis (Conama/Ibama). Determinar à sua Secretaria Executiva, que... Resolução Conama, nº 24, 18 de setembro de 1986. Resoluções, Brasília, setembro de 1986.

Conselho Nacional do Meio Ambiente - Instituto Brasileiro do Meio Ambiente e dos Recursos Naturais Renováveis (Conama/Ibama). Dispõe sobre o licenciamento ambiental de obras do setor de geração de energia elétrica. Resolução Conama, $\mathrm{n}^{\circ}$ 06, 22 de outubro de 1987. Resoluções, Brasília, outubro de 1987.

BRASIL. Constituição (1988). A Constituição do Brasil 1988: comparada e comentada. São Paulo: Price Waterhouse, 1989, 1028 p.

BUNGUE, Thomas. As Bases Legais do Estudo de Impacto Ambiental. Tradução de Erika Patsh Pineda. In: AB'SÁBER, Aziz Nacib \& MÜLLER-PLANTENBERG, Clarita (Orgs.). Previsão de impactos. $2^{a}$ edição. São Paulo: Edusp, 2006. p. 391-406.

BURMAN, E. I.; DANILOV-DANILKHAN, V. I. Impctos Ambientais e Desenvolvimento Social: O Estudo de Impacto Ambiental. Tradução de Andrea Cristina Bianchi Alves. In: AB'SÁBER, Aziz Nacib \& MÜlLER-PLANTENBERG, Clarita (Orgs.). Previsão de impactos. $2^{a}$ edição. São Paulo: Edusp, 2006. p. 195-204.

BURTSEV, A. S. A Indústria Nuclear: Peritagem Ecológica e Ambiental. Andrea Cristina Bianchi Alves. In: AB'SÁBER, Aziz Nacib \& MÜLLER-PLANTENBERG, Clarita (Orgs.). Previsão de impactos. $2^{\text {a }}$ edição. São Paulo: Edusp, 2006. p. 279-288.

CHRISTANTE, Luciana. Hormônios na Água. Unespciência. São Paulo, ano 01, n. 06, p. 1825, mar. 2010.

CLAVAL, Paul. Evolución de la Geografía Humana. Barcelona: Gráficas García, 1974.

As Abordagens da Geografia Cultural. In: CASTRO, Iná Elias de; GOMES, Paulo César da Costa; CORRÊA, Roberto Lobato (Orgs.). Explorações Geográficas: percursos no fim do século. Rio de Janeiro: Bertrand Brasil, 1997. p. 89-118.

Campo e Perspectivas da Geografia Cultural. In: CORRÊA, Roberto Lobato; ROSENDAHL, Zeny (Orgs.). Geografia Cultural: um século (3). Rio de Janeiro: Eduerj, 2002. p. 133-190.

A Geografia Cultural. Tradução de Luiz Fugazzola Pimenta e Margareth de Castro Afeche Pimenta. $3^{\text {a }}$ edição. Florianópolis: Ed. da UFSC, 2007. 453 p. 
COELHO, André Luiz Nascentes. Geomorfologia Fluvial de Rios Impactados por Barragens. Caminhos de Geografia: revista on line, Uberlândia, vol. 9, nº 26, p. 16-32, jun., 2008.

COMPANHIA DE SANEAMENTO DE SERGIPE - Deso/SE. Sistemas Integrados de Abastecimentos de Água - 2007 [mensagem pessoal]. Mensagem recebida por <regnaldogouveia@usp.br>em 28 de setembro de 2012.

Gestão do Sistema de Controle Operacional - 2010 [mensagem pessoal]. Mensagem recebida por <regnaldogouveia@usp.br> em 22 de fevereiro de 2014.

CONTI, José Bueno; FURLAN, Sueli Ângelo. Geoecologia: o clima, os solos e a biota. In: ROSS, Jurandir L. Sanches (Org.). Geografia do Brasil. 5 ${ }^{\text {a }}$ edição rev. e ampl. São Paulo: Edusp, 2005. p. 67-208.

CONTI, José Bueno. Clima e meio ambiente. $7^{\text {a }}$ edição revista e atualizada. São Paulo: Atual, 2011.96 p. (Série meio ambiente).

CORRÊA, Roberto Lobato; ROSENDAHL, Zeny. Apresentando Leituras sobre Paisagem, Tempo e Cultura. In: Paisagem, tempo e cultura. Rio de Janeiro: Eduerj, 1998. p. 07-11.

CORRÊA, Roberto Lobato. A Geografia Cultura e o Urbano. In: CORRÊA, Roberto Lobato; ROSENDAHL, Zeny (Orgs.). Introdução à Geografia Cultural. Rio de Janeiro: Bertrand Brasil, 2003. p. 167-186.

COSGROVE, Denis E.; JACKSON, Peter. Novos Rumos da Geografia Cultural. In: CORRÊA, Roberto Lobato; ROSENDAHL, Zeny (Orgs.). Introdução à Geografia Cultural. Rio de Janeiro: Bertrand Brasil, 2003. p. 135-166.

COUTURE, Alex; EATON, Lauren. The Human Impacts on River Nile. University of Michigan. Michigan, Seção Mudança Global 004, Grupo 5, 2007.

CRITÉRIO. In: RUTH ROCHA. Minidicionário. São Paulo: Ed. Scipione, 1996. p. 178.

CRITÉRIO. In: GERALDO MATTOS. Dicionário júnior. $3^{\mathrm{a}}$ edição. São Paulo: Ed. FTD, 2005. p. 162.

CUNHA, Euclides da. Os Sertões: campanha de Canudos. $2^{\mathrm{a}}$ edição. $2^{\mathrm{a}}$ impressão. São Paulo: Ática, 2000. 752 p. (Série bom livro, especial).

DEPARTAMENTO NACIONAL DA PRODUÇÃO MINERAL (Dnpm). Projeto Radam: Levantamento de Recursos Naturais. Volume 01. Rio de Janeiro: [s.n.], 1973. 284 p.

DIARRA, S. Geografia histórica: aspectos físicos. In: KI-ZERBO, Joseph. História Geral da África, I: Metodologia e pré-história da África. 2a edição. Brasília: Unesco, 2010. p. 345-366.

DUBININA, V. G.; LABLOKOV, A. V. Trajetória de um Projeto: O Canal Volga-Tchograi. In: AB'SÁBER, Aziz Nacib \& PLANTENBERG, Clarita Müller (org). Previsão de impactos. $2^{a}$ edição. São Paulo: Edusp, 2006. p. 299-312. 
ECOLOGY BRASIL - Ecology And Evironment do Brasil; AGRAR - Agrar Consultoria e Estudos Técnicos S/C Ltda; JP Meio Ambiente Ltda. Projeto de Integração do Rio São Francisco com Bacias Hidrográficas do Nordeste Setentrional - Consolidação dos Estudos Ambientais. EIA Consolidado Item 01. Apresentação. Rio de Janeiro: [s.n.]. 2004. $04 \mathrm{p}$.

Projeto de Integração do Rio São Francisco com Bacias Hidrográficas do Nordeste Setentrional - Consolidação dos Estudos Ambientais. EIA Consolidado Item 02. Caracterização do Empreendimento. Rio de Janeiro: [s.n.]. 2004. 96 p.

Projeto de Integração do Rio São Francisco com Bacias Hidrográficas do Nordeste Setentrional - Consolidação dos Estudos Ambientais. EIA Consolidado Item 03. Análise das Alternativas. Rio de Janeiro: [s.n.]. 2004. 70 p.

Projeto de Integração do Rio São Francisco com Bacias Hidrográficas do Nordeste Setentrional - Consolidação dos Estudos Ambientais. EIA Consolidado Item 04. Áreas de Estudo. Rio de Janeiro: [s.n.]. 2004. 09 p.

Projeto de Integração do Rio São Francisco com Bacias Hidrográficas do Nordeste Setentrional - Consolidação dos Estudos Ambientais. EIA Consolidado Item 5.3.4. Diagnóstico Ambiental da Área de Influência Indireta. Rio de Janeiro: [s.n.]. 2004. 174 p.

Projeto de Integração do Rio São Francisco com Bacias Hidrográficas do Nordeste Setentrional - Consolidação dos Estudos Ambientais. EIA Consolidado Item 5.4.3. Aspectos Biológicos. Rio de Janeiro: [s.n.]. 2004. 259 p.

Projeto de Integração do Rio São Francisco com Bacias Hidrográficas do Nordeste Setentrional - Consolidação dos Estudos Ambientais. EIA Consolidado Item 06. Diagnóstico Ambiental da Área de Influência Direta. Rio de Janeiro: [s.n.]. 2004. 298 p.

Projeto de Integração do Rio São Francisco com Bacias Hidrográficas do Nordeste Setentrional - Consolidação dos Estudos Ambientais. EIA Consolidado Item 6.5. Meio Socioeconômico. Rio de Janeiro: [s.n.]. 2004. 177 p.

Projeto de Integração do Rio São Francisco com Bacias Hidrográficas do Nordeste Setentrional - Consolidação dos Estudos Ambientais. EIA Consolidado Item 6.5.9. Comunidades Especiais. Rio de Janeiro: [s.n.]. 2004. 140 p.

Projeto de Integração do Rio São Francisco com Bacias Hidrográficas do Nordeste Setentrional - Consolidação dos Estudos Ambientais. EIA Consolidado Item 07. Diagnóstico Ambiental da Área Diretamente Afetada. Rio de Janeiro: [s.n.]. 2004. 82 p.

Projeto de Integração do Rio São Francisco com Bacias Hidrográficas do Nordeste Setentrional - Consolidação dos Estudos Ambientais. EIA Consolidado Item 08. Análise Integrada. Rio de Janeiro: [s.n.]. 2004. 45 p.

Projeto de Integração do Rio São Francisco com Bacias Hidrográficas do Nordeste Setentrional - Consolidação dos Estudos Ambientais. EIA Consolidado Item 09. Planos e Programas Governamentais. Rio de Janeiro: [s.n.]. 2004. 66 p. 
Projeto de Integração do Rio São Francisco com Bacias Hidrográficas do Nordeste Setentrional - Consolidação dos Estudos Ambientais. EIA Consolidado Item 10. Legislação Incidente e Aplicável. Rio de Janeiro: [s.n.]. 2004. 39 p.

Projeto de Integração do Rio São Francisco com Bacias Hidrográficas do Nordeste Setentrional - Consolidação dos Estudos Ambientais. EIA Consolidado Item 11. Análise dos Impactos Ambientais e Medidas Recomendadas. Rio de Janeiro: [s.n.]. 2004. 120 p.

Projeto de Integração do Rio São Francisco com Bacias Hidrográficas do Nordeste Setentrional - Consolidação dos Estudos Ambientais. EIA Consolidado Item 12. Programas Ambientais. Rio de Janeiro: [s.n.]. 2004. 186 p.

Projeto de Integração do Rio São Francisco com Bacias Hidrográficas do Nordeste Setentrional - Consolidação dos Estudos Ambientais. EIA Consolidado Item 13. Cenários Futuros. Rio de Janeiro: [s.n.]. 2004. 10 p.

Projeto de Integração do Rio São Francisco com Bacias Hidrográficas do Nordeste Setentrional - Consolidação dos Estudos Ambientais. EIA Consolidado Item 14. Bibliografia. Rio de Janeiro: [s.n.]. 2004. 80 p.

Projeto de Integração do Rio São Francisco com Bacias Hidrográficas do Nordeste Setentrional - Consolidação dos Estudos Ambientais. EIA Consolidado Item 15. Equipe Técnica. Rio de Janeiro: [s.n.]. 2004. 04 p.

Projeto de Integração do Rio São Francisco com Bacias Hidrográficas do Nordeste Setentrional - Consolidação dos Estudos Ambientais. EIA Consolidado Item 16. Glossário. Rio de Janeiro: [s.n.]. 2004. 07 p.

Projeto de Integração do Rio São Francisco com Bacias Hidrográficas do Nordeste Setentrional - Consolidação dos Estudos Ambientais. Áreas e Projetos Integráveis. Rio de Janeiro: [s.n.]. 2004. 1 mapa color. Escala 1:1.250.000.

ENCYCLOPAEDIA BRITANNICA, INC. (2011). River Nile. Disponível em: <http://www.global.britannica.com/EBchecked/topic/415347/Nile-River >. Acesso em 16 de outubro de 2013.

ENGE-RIO - ENGENHARIA E CONSULTORIA S.A. Usina Hidrelétrica de Xingó: Estudo de Impacto Ambiental - EIA. Apresentação. Rio de Janeiro: [s.n.]. 1993. 34 p.

Usina hidrelétrica de Xingó: Estudo de Impacto Ambiental - EIA. Tomo I memorial descritivo do empreendimento. Rio de Janeiro: [s.n.]. 1993. 113 p.

Usina hidrelétrica de Xingó: Estudo de Impacto Ambiental - EIA. Tomo II diagnóstico ambiental, volume 01 - meio físico. Rio de Janeiro: [s.n.]. 1993. 282 p.

Usina hidrelétrica de Xingó: Estudo de Impacto Ambiental - EIA. Tomo II diagnóstico ambiental, volume 02 - meio biótico. Rio de Janeiro: [s.n.]. 1993. 201 p. 
Usina hidrelétrica de Xingó: Estudo de Impacto Ambiental - EIA. Tomo II diagnóstico ambiental, volume 03 - meio antrópico. Rio de Janeiro: [s.n.]. 1993. 208 p.

Usina hidrelétrica de Xingó: Estudo de Impacto Ambiental - EIA. Tomo III prognóstico ambiental. Rio de Janeiro: [s.n.]. 1993. 86 p.

Usina hidrelétrica de Xingó: Estudo de Impacto Ambiental - EIA. Tomo IV programas ambientais. Rio de Janeiro: [s.n.]. 1993. 64 p.

Aspectos Gerais do Empreendimento. In: Usina hidrelétrica de Xingó.

Projeto Básico Ambiental - PBA: programa de manejo e conservação da fauna aquática. Rio de Janeiro: [s.n.]. 1994. p. 1-10.

Projeto de Manejo e Conservação da Fauna Aquática. In: - Usina hidrelétrica de Xingó. Projeto Básico Ambiental - PBA: programa de manejo e conservação da fauna aquática. Rio de Janeiro: [s.n.]. 1994. p. 11-62.

Relatório de Impacto Ambiental - Rima: Usina Hidrelétrica de Xingó - UHE XINGÓ. Rio de Janeiro: [s.n.], [1993 ou 1994]. 108 p.

ESTIENNE, P. \& GODARD, A. Climatologia. Paris: Armand Colin, 1970.

FALCÃO SOBRINHO, José. Relevo e Paisagem: proposta metodológica. Sobral: Sobral Gráfica, 2007. 108 p.

FANOS, Alfy Morcos. The Impact of Human Activities on the Erosion and Accretion of the Nile Delta Coast. Journal of Coastal Research. [S.1.], summer 1995. Coastal Education \& Research Foundation, Inc. Vol. 11, no 3, p. 821-833.

FERREIRA. Graça M. Lemos. Atlas Geográfico: espaço mundial. $2^{\mathrm{a}}$ edição. São Paulo: Moderna, 2003.

HARVEY, David. A condição pós-moderna. São Paulo: Loyola, 1992. 220 p.

HEGEL, G. W. F. Philosophia da Natureza. In: Encyclopedia das Sciencias

Philosophicas (em compêndio). Tradução de Lívio Xavier. São Paulo: Impressora Comercial, 1936. p. 239-251.

INSTITUTO BRASILEIRO DE GEOGRAFIA E ESTATÍSTICA - Ibge. Carta Internacional do Mundo ao $1.000 .000^{\circ}$ : Aracaju, folha SC-24. Rio de Janeiro: Ibge, 1998. 1 folha topográfica, color. Escala 1:1.000.000.

Carta Internacional do Mundo ao $1.000 .000^{\circ}$ : Belo Horizonte, folha SE-23. Rio de Janeiro: Ibge, 1998. 1 folha topográfica, color. Escala 1:1.000.000.

Carta Internacional do Mundo ao 1.000.000': Brasília, folha SD-23. Rio de Janeiro: Ibge, 1998. 1 folha topográfica, color. Escala 1:1.000.000.

Carta Internacional do Mundo ao 1.000.000': Jaguaribe, folha SB-24. Rio de Janeiro: Ibge, 1998. 1 folha topográfica, color. Escala 1:1.000.000. 
Carta Internacional do Mundo ao $1.000 .000^{\circ}$ : Rio de Janeiro, folha SF-23. Rio de Janeiro: Ibge, 1998. 1 folha topográfica, color. Escala 1:1.000.000.

Carta Internacional do Mundo ao $1.000 .000^{\circ}$ : Rio São Francisco, folha SC-23. Rio de Janeiro: Ibge, 1998. 1 folha topográfica, color. Escala 1:1.000.000.

Vegetação: cobertura atual, Diretoria de Geociências, Coordenação de Recursos Naturais e Estudos Ambientais - Geociências. Disponível em: 〈http://www.ibge.gov.br $>$. Acesso em 26 de setembro de 2013.

Base cartográfica: malha digital de Sergipe, Diretoria de Geociências, Coordenação de Recursos Naturais e Estudos Ambientais - Geociências. Disponível em: <http://www.ibge.gov.br>. Acesso em 29 de março de 2014.

JPEG. 198?. Altura: 384 pixels. Largura: 579 pixels. CMYK 37,6 KB. Formato JPG. Compactado. Disponível em: <www.tribunadapraiaonline.com>. Acesso online, em dezembro de 2014.

KANT, Immanuel. Doutrina Transcendental dos Elementos. In: Crítica à Razão Pura. Os Pensadores. Tradução de Valério Rohden e Udo Baldur Moosburger. São Paulo: Abril Cultural, 1980. p. 37-56.

LAGE, Creuza Santos. Refletindo Sobre o Projeto de Pesquisa em Geografia. Salvador: Universidade Federal da Bahia, 2002. 23 p.

LANDIM, Elvídio (Gerente da Divisão do Meio Ambiente de Geração da Companhia Hidro Elétrica São Francisco (Chesf)). Entrevista concedida a Regnaldo Gouveia dos Santos. Recife, 10 de janeiro de 2014.

LARRABURE, Sara Pugliesi. O Fenômeno da Segunda Residência: o caso do Rio Grande entre os Estados de São Paulo e Minas Gerais. Revista Geousp: Espaço e Tempo, São Paulo, Edição Especial, p. 93-105, dezembro, 2009.

MAGNOLI, Demétrio; ARBEX JÚNIOR, José; OLIC, Nelson Bacic. Panorama do Mundo. São Paulo: Editora Scipione, 1997. 110 p.

MAKSIMENKO, Iúri L. Forças Produtivas e o Estudo de Impacto Ambiental: Exigências e Procedimentos na Aprovação de Projetos. Tradução de Andrea Cristina Bianchi Alves. In: AB'SÁBER, Aziz Nacib \& MÜlLER-PLANTENBERG, Clarita (Orgs.). Previsão de impactos. $2^{a}$ edição. São Paulo: Edusp, 2006. p. 213-222.

MARTINS, José de Souza. Capitalismo e Tradicionalismo: estudos sobre as contradições da sociedade agrária no Brasil. São Paulo: Pioneira, 1975. 161p.

MELLO, Claudio Prado de. Viagem ao Alto Nilo: O Egito de D. Pedro II. Rio de Janeiro, Instituto de Egiptologia, 1996. 44 p.

MENEZES, Ana Célia Silva; ROCHA, Flávio (Orgs.). A Resistência à Transposição do Rio São Francisco na Paraíba: Histórias de Luta em Defesa da Terra, das Águas e dos Povos do Nordeste. João Pessoa: Sal da Terra, 2010. 76 p. 
MILARÉ, Édis. Estudo Prévio de Impacto Ambiental no Brasil. In: AB'SABER, Aziz Nacib; MÜLLER-PLANTENBERG, Clarita (Orgs.). Previsão de impactos: o estudo de impacto ambiental no Leste, Oeste e Sul: experiências no Brasil, na Rússia e na Alemanha. $2^{\mathrm{a}}$ edição. São Paulo: Edusp, 2006. p. 51-83.

MINISTÉRIO DAS MINAS E ENERGIA (MME). Projeto Radambrasil: Levantamento de Recursos Naturais. Volume 24. Rio de Janeiro: [s.n.], 1981. 624 p.

Projeto Radambrasil: Levantamento de Recursos Naturais. Volume 29. Rio de Janeiro: [s.n.], 1982. 659 p.

Projeto Radambrasil: Levantamento de Recursos Naturais. Volume 30. Rio de Janeiro: [s.n.], 1983. 855 p.

Projeto Radambrasil: Levantamento de Recursos Naturais. Volume 32. Rio de Janeiro: [s.n.], 1983. 779 p.

MINKOWISK, H. Espaço e Tempo. In: EINSTEIN. A.; LORENTZ, H. A. e MINKOWISK, H. Textos Fundamentais da Física Moderna. O Princípio da Relatividade. Tradução de Mário José Saraiva. Volume I. Lisboa: Editora Fundação Calouste Gulbendian, 1989. p. 93123.

MOTA, Clarice Novaes da. Antes (e depois) do Rio São Francisco: os verdadeiros descobridores do Opara. In: SÁ, Antônio Fernando de Araújo; BRASIL, Vanessa Maria (Orgs.). Rio Sem História? Leituras sobre o Rio São Francisco. Aracaju: Fapese, 2005. p. 91 104.

MÜLLER-PLANTENBERG, Clarita. A Necessidade do Estudo de Impacto Ambiental Social e Global. Tradução de Regina Johas. In: AB'SÁBER, Aziz Nacib \& MÜLLER-PLANTENBERG, Clarita (Orgs.). Previsão de impactos. $2^{a}$ edição. São Paulo: Edusp, 2006. p. 551-566.

NASCIMENTO, Maria Anunciada Júnior do. Entrevista concedida a Regnaldo Gouveia dos Santos. Três Marias, 01 de julho de 2012.

NEWTON, Isaac. Definições: Axiomas ou Leis do Movimento. In: Principia

Princípios Matemáticos de Filosofia Natural. Tradução de Triete Ricci, Leonardo Gregory Brunet, Sônia Terezinha Gehring, Maria Helena Curcio Célia. Volume I. São Paulo: Edusp e Nova Estella, 1990. p. 1-15.

NICOL, Alan. The Nile: moving beyond cooperation. Edição I. Paris: Unesco, 2003. 33 p. (Séries PC - CP, 16).

NICOLAU, D. José; BELLACASA, D. Narciso Puig de la. Las Obras de Riego en Egipto. Revista de Obras Públicas. Madri, p. 265-276, agosto. 1905.

NIMER, Edmon. Climatologia do Brasil. $2^{\mathrm{a}}$ edição. Rio de Janeiro: Ibge, 1989. 422 p.

OLIVEIRA, Evelina Antunes F. de. Nos Trilhos da História de Piranhas: um ensaio sobre a Estrada de Ferro Paulo Afonso. In: SÁ, Antônio Fernando de Araújo; BRASIL, Vanessa 
Maria (Orgs.). Rio Sem História? Leituras sobre o Rio São Francisco. Aracaju: Fapese, 2005. p. 221-239.

O NILO, rio dos deuses. Produção e direção de Michael McKinnon. [S.1.]. Pasa e Discovery Communications Inc., 2002. 1 DVD.

PDF. 2014. Altura: 7,36 cm. Largura: 8,94 cm. 327,239 bytes. CMYK 319 KB. Formato PDF. Compactado. Disponível em: <www.googlemaps.com.br>. Acesso online, em outubro de 2014.

QUEIROZ FILHO, Alfredo Pereira de; DE BIASI, Mário. Técnicas de Cartografia. In: VENTURI, Luis Antonio Bittar (Org.). Geografia: práticas de campo, laboratório e sala de aula. São Paulo: Editora Sarandi, 2011. p. 171-202.

QUEIROZ, Maria Isaura Pereira de. Histórias de Vida e Depoimentos Pessoais. In: LUCENA, Célia Toledo; CAMPOS, Maria Christina Siqueira de Souza; DEMARTINI, Zeila de Brito Fabri (Orgs.). Pesquisa em Ciências Sociais: olhares de Maria Isaura Pereira de Queiroz. Coleção textos, série 02, n. 10. São Paulo: Humanitas, 2008. p. 79-98.

REBOUÇAS, Aldo da Cunha. Água doce no mundo e no Brasil. In: REBOUÇAS, Aldo da Cunha; BRAGA, Benedito; TUNDISI, José Galízia (Orgs.). Águas doces no Brasil: capital ecológico, uso e conservação. São Paulo: Escrituras, 1999. p. 1-38.

RIBEIRO JÚNIOR, Carlos Eduardo (Presidente da Organização Não Governamental (ONG) Canoa de Tolda). Entrevista concedida a Regnaldo Gouveia dos Santos. Brejo Grande/SE, 03 de janeiro de 2014.

REYER, Georges. Fotografia aérea do Delta do Rio Nilo no início da década de 1970. In: Nilo. [S. 1.: s. n.], [1974?].

RODRIGUES, Cleide; ADAMI, Samuel. Técnicas de hidrografia. In: VENTURI, Luis A. Bittar (Org.). Geografia: Práticas de Campo, laboratório e Sala de Aula. São Paulo: Editora Sarandi, 2011. p. 55-82.

RODRIGUES, Roberto Carlos (Secretário Municipal de Agricultura do Município Três Marias/MG). Entrevista concedida a Regnaldo Gouveia dos Santos. Três Marias/MG, 02 de julho de 2012.

ROSS, Jurandir L. Sanches (Org.). Geografia do Brasil. $5^{\text {a }}$ edição rev. e ampl. São Paulo: Edusp, 2005. 549 p.

SÁ, José. Entrevista concedida a Regnaldo Gouveia dos Santos. Piaçabuçu/AL, 03 de janeiro de 2014.

SANCHES, Luiz Antonio Ugueda. A geografia da Energia no Brasil - parte 1: do Império ao Estado Novo. Geografia, São Paulo, Edição nº 38, p. 38-47, julho, 2011.

A Geografia da Energia no Brasil - parte 2: dos anos 40 aos dias de hoje. Geografia, São Paulo, Edição no 39, p. 38-47, agosto, 2011. 
SÁNCHEZ, Luis E. Avaliação de Impacto Ambiental: conceitos e métodos. São Paulo: Oficina de Textos, 2006. Capítulo 01. p. 17-43.

SANTOS, Milton. A Natureza do Espaço: técnica e tempo - razão e emoção. São Paulo: Edusp, 1996.

Da Sociedade à Paisagem. In: Pensando o Espaço do Homem. $5^{\text {a }}$ edição. São Paulo: Edusp, 2007. p. 53-64.

SANTOS, Regnaldo Gouveia dos. Impactos Socioambientais à Margem do Rio São Francisco: um estudo de caso. 2008. 193 f. Dissertação de Mestrado - Dpgeo/Fflch-USP, São Paulo, 2008.

Impactos Socioambientais à Margem do Rio São Francisco: relação homem $\mathrm{x}$ natureza. São Paulo: Biblioteca 24x7 - Seven System Internacional, 2010. 192 p.

SAUER, Carl O. A Morfologia da Paisagem. In: CORREAA, Roberto Lobato; ROSENDAHL, Zeny (Orgs.). Paisagem, tempo e cultura. Rio de Janeiro: Eduerj, 1998. p. 12-74.

Geografia Cultural. In: CORREAA, Roberto Lobato; ROSENDAHL, Zeny (Orgs.). Introdução à Geografia Cultural. Rio de Janeiro: Bertrand Brasil, 2003. p. 19-26.

SCALZARETTO, Reinaldo. Geografia Geral: nova geopolítica. $4^{a}$ edição. São Paulo: Editora Scipione, 1995. 343 p.

SCARPIN, Paula. Era uma vez a transposição: projeto de levar água do São Francisco para o sertão empaca com erros do governo e descaso das empreiteiras. Piauí_75, [S.1.], 75, ano 7, p. 28-34, dez. 2012.

SCHLÜPMANN, Klaus. Direito do Cidadão e Estrada Real: Sobre a Pré-história da Lei da UVP. Tradução de Maria Clara Cescato. In: AB'SÁBER, Aziz Nacib \& MÜLLER-PLANTENBERG, Clarita (Orgs.). Previsão de impactos. $2^{a}$ edição. São Paulo: Edusp, 2006. p. 351-376.

SHARAF el DIN, S. H. Effect of the Aswan High Dam on the Nile Flood and on the Estuarine and Coastal Circulation Pattern Along the Mediterranean Egyptian Coast. ASLO: Limnology and Oceanography. Alexandria, vol. 22, nº 2, p. 194-207, mar., 1977.

SILVA, Geraldo Soares. Entrevista concedida a Regnaldo Gouveia dos Santos. Brejo Grande/SE, 03 de janeiro de 2014.

SIMIELLI, Maria Elena. Atlas Geográfico Escolar. 33ª edição ampliada e atualizada. São Paulo: Ática, 2002. 48 p.

SIMÕES, Edlamar Nascimento Oliveira. Entrevista concedida a Regnaldo Gouveia dos Santos. Nossa Senhora do Socorro/SE, 04 de janeiro de 2014.

SOUZA, Diógenes de. Sergipe pode se tornar polo de minério em 2013. Infonet, Aracaju, 17 set. 2010. Economia. Página principal. 
STRAHLER, A. N. Physical Geography. $3^{\text {a }}$ edição. New York: Wiley, c1969.

SUMMERER, Stefan. O Estudo de Impacto Ambiental: Forma Jurídica, Processo, Participantes. Tradução de Erika Patsch Pineda. In: AB'SÁBER, Aziz Nacib \& MÜLLER-PLANTENBERG, Clarita (Orgs.). Previsão de impactos. 2a edição. São Paulo: Edusp, 2006. p. 407-418.

TEIXEIRA, Maria Gracinda et al. Análise dos Relatórios de Impactos Ambientais de Grandes Hidrelétricas no Brasil. In: AB'SABER, Aziz Nacib; MÜLLER-PLANTENBERG, Clarita (Orgs.). Previsão de Impactos: o Estudo de Impacto Ambiental no Leste, Oeste e Sul: experiências no Brasil, na Rússia e na Alemanha. $2^{a}$ edição, São Paulo: Edusp, 2006. p. 163186.

THÉRY, Hervé; MELLO, Neli Aparecida de. Atlas do Brasil: disparidades e dinâmicas do território. São Paulo: Edusp, 2005. 312 p.

TINOCO, Juliana. A revolução brasileira. Revista Greenpeace. São Paulo, p. 12-13, outubro, novembro, dezembro, 2010.

UNGER, Nancy Mangabeira. Da Foz à Nascente: o recado do rio. $2^{\text {a }}$ edição. São Paulo: Cortez; Editora da Unicamp, 2001. 201 p.

VALENTE, Renata de Melo et al. Conservação de Aves Migratórias Neárticas no Brasil. Belém: Conservação Internacional (CI-Brasil), 2011. 400 p.

VENTUROLI, Thereza. Dossiê Água: o Mundo com sede. Revista Atualidades, São Paulo, edição $n^{\circ} 9$, p. 24-43, $1^{\circ}$ semestre, 2009.

VIEIRA, José Eriberto Pinheiro - Chefe da EMDAGRO do município de Neópolis/SE. Entrevista concedida a Regnaldo Gouveia dos Santos. Neópolis/SE, 08 de janeiro de 2013.

VIEIRA, Sônia. Como Escrever Uma Tese. São Paulo: Livraria Pioneira Editora, 1991. 81 p.

ZERETZKE, Herbert. O Problema da Conversão. Tradução de Heloísa Silveira Mello. In: AB'SÁBER, Aziz Nacib \& MÜlLER-PLANTENBERG, Clarita (Orgs.). Previsão de impactos. $2^{\text {a }}$ edição. São Paulo: Edusp, 2006. p. 523-542. 
ANEXOS 
ANEXO A - FORMULÁRIO DE ENTREVISTA I

ENTREVISTA I: dirigida a representante institucional ou representante público

ENTREVISTA I: ÁREA DE INFLUÊNCIA REAL DE EMPREENDIMENTOS HIDROELÉTRICOS DO PONTO DE VISTA DA GEOGRAFIA: o Caso da Bacia São Francisco

$\mathrm{N}^{\mathrm{o}}$ :

Data:

Nome:

Grau de instrução:

Localidade:

1) O que entende por impacto ambiental?

2) De que maneira é possível perceber o impacto ambiental quando se trata de um rio interferido pela execução e operação de empreendimentos hidroelétricos?

4) Até aonde os impactos socioambientais, a partir dos empreendimentos hidroelétricos, podem se alastrar?

5) Os valores culturais do povo do lugar impactado por tal ação humana no ambiente do rio interferido precisam ser considerados pelo EIA/Rima? De que maneira? Por quê?

6) Diante disso, mensure o tamanho da área de influência considerando os impactos socioambientais resultados da execução e operação de empreendimentos hidroelétricos na perspectiva de abarcar o espaço como um todo vulnerável a tais impactos.

7) Quando as consequências do impacto ambiental passam a ser detectadas fora da bacia hidrográfica do rio interferido, as áreas assim atingidas merecem ser consideradas como área de influência do empreendimento hidroelétrico por este assim também ser a principal causa dos impactos através da ação do homem? Por quê?

8) A legislação brasileira sobre a mitigação dos impactos ambientais ou socioambientais é suficiente a esse respeito? 
9) Mediante o avanço tecnológico, considerado, em termos, como principal vetor de poluição quando se refere ao uso do solo e da água, principalmente, se tratando da agricultura irrigada e do abastecimento humano, em que implica ponderar sobre a área de influência de empreendimentos hidroelétricos com potencial acima de $10 \mathrm{MW}$, a respeito das possibilidades de um ajuste das leis nacionais e internacionais regulamentadoras do EIA/Rima? 


\section{ANEXO B - FORMULÁRIO DE ENTREVISTA II \\ ENTREVISTA II: dirigida à pessoa comum habitante da bacia hidrográfica do Rio São Francisco}

\section{ENTREVISTA II: ÁREA DE INFLUENCIA REAL DE EMPREENDIMENTOS HIDROELÉTRICOS DO PONTO DE VISTA DA GEOGRAFIA: o Caso da Bacia São Francisco}

$\mathrm{N}^{\mathrm{o}}$ :

Data:

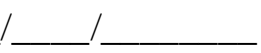

Nome:

Grau de instrução:

Localidade:

1) Fale sobre a importância do meio ambiente do São Francisco enquanto durou o ciclo de cheias naturais, no sentido de esclarecer como contribuiu no seu modo de viver se relacionando com o rio; diga também quais os tipos de peixes eram pescados.

2) Fale sobre a importância do meio ambiente do São Francisco conforme se apresenta hoje em dia, no sentido de como está contribuindo no seu modo de viver se relacionando com o rio; fale também dos tipos de peixes pescados.

3) No tempo em que existia cheia do Rio São Francisco todo ano, o que você mais valorizava na relação que você tinha com o rio?

4) Qual o valor que isso significava na sua vida?

5) Explique de que maneira você valorizava sua relação com o rio naqueles tempos quando existia o ciclo de cheias naturais.

6) A sua relação com o rio naqueles tempos era encarada como um valor?

7) De que maneira, ou seja, como se caracterizava o valor cultural que você adquiriu vivenciando o ambiente e se envolvendo com o rio através de seu modo de vida, naqueles tempos? 
8) Explique como ou em que o Rio São Francisco influenciou na sua vida: e quando isso foi mais marcante?

9) Antes da existência da barragem hidrelétrica de Xingó, até por volta do final da década de 1980, era possível sentir sabor de sal na água de abastecimento público para beber (dessedentação humana)? Explique qual era a sensação ao beber a água.

11) Refletindo sobre a natureza do rio, as mudanças ocorridas no seu leito significaram melhora ou piora para a maioria das pessoas? Explique.

10) Hoje em dia, o Rio São Francisco influencia na sua vida de que maneira? É possível sentir sabor de sal na água? Explique qual a sensação ao bebê-la. 
ANEXO C - FORMULÁRIO DE ENTREVISTA III

ENTREVISTA III: dirigida à pessoa comum habitante de fora da bacia hidrográfica do Rio São Francisco

\section{ENTREVISTA III: ÁREA DE INFLUENCIA REAL DE EMPREENDIMENTOS HIDROELÉTRICOS DO PONTO DE VISTA DA GEOGRAFIA: o Caso da Bacia São Francisco}

$\mathrm{N}^{\mathrm{o}}$ :

Data:

Nome:

Grau de instrução:

Localidade:

1) Fale sobre a importância do São Francisco nesta região que fica fora da bacia hidrográfica, de maneira que esclareça qual a possível relação existente entre os habitantes e o rio.

2) Explique qual a importância desse rio para o modo de vida do povo desta região que está fora da bacia hidrográfica.

3) Que valor é possível destinar à existência do São Francisco, no sentido da relação (dependência) das pessoas desta região com esse rio?

4) Explique de que maneira você valoriza sua relação com o rio.

5) Sabendo que a alteração da qualidade da água no curso do rio pode alcançar esta região de fora da bacia hidrográfica, cada ponto abastecido a partir de suas adutoras deve ser considerado como área de influência dos empreendimentos hidroelétricos, causa dessa alteração? Explique. 


\section{ANEXO D - FORMULÁRIO DE ENTREVISTA REALIZADA COM REPRESENTANTE INSTITUCIONAL: entrevista dirigida a representante institucional do setor agrícola}

$\mathrm{N}^{\mathrm{o}}$ :

Data:

Nome:

Localidade:

Quais são as frutas produzidas nesse município?

Qual o destino da produção dessas frutas?

Na região, há algum tipo de processamento dessas frutas para o setor industrial?

Alguma outra região utiliza essas frutas como matéria-prima na indústria?

Qual é a finalidade de tal matéria-prima?

Qual região ou lugar que utiliza as frutas como matéria-prima?

Conhece alguma empresa que utiliza as frutas como matéria-prima?

Qual (is) o(s) nome(s) dessa(s) empresa(s)?

Qual a dimensão que os pequenos produtores ocupam produzindo as frutas ou outras atividades relacionadas ao uso da água do rio?

As lavouras desses pequenos produtores estão a que distância do rio?

Em que ponto se concentra a produção das frutas, em relação à distância do curso do rio?

Como sobrevivem os sertanejos camponeses (deste município) distantes do rio?

Há alguma irrigação que alcança os camponeses sertanejos que residem distante do rio?

Caso a resposta anterior seja sim, qual é a distância em relação ao rio que esses camponeses são atendidos por tal irrigação? 
Há algum grupo empresarial da agricultura que não é natural da região destes municípios banhados pelo rio, produzindo (cultivando) no mesmo espaço em que se localizam os pequenos produtores?

Favor citar o(s) nome(s) desse(s) grupo(s):

Como foi e como é dividida a terra cultivável dessas frutas nessa região?

Qual é a parcela dessa terra que pertence aos pequenos produtores?

Qual é a parcela dessa terra que pertence aos grandes produtores?

Há alguma terra arrendada para o cultivo das frutas? Qual a área?

Em alguma época essa terra esteve arrendada para o cultivo dessas frutas? Quando?

Como foram adquiridas as terras de posse dos pequenos produtores?

Como foram adquiridas as terras de posse dos grandes produtores?

A quem pertencem as terras produtoras hoje em dia?

A partir de quando tudo começou (em relação ao cultivo dessas frutas) na região e quando passa a ganhar maior destaque?

Como o destaque, que hoje se conhece a respeito do potencial agrícola desses dois municípios se expandiu, atingindo até o exterior?

A condição de destaque da produção dessa região começou atendendo, primeiramente, a região ou já começou direto para atender ao exterior com a exportação?

Como as terras foram divididas para produção das frutas?

Se é que ocorreu, quando aconteceu a divisão dessas terras?

Como se configura o poder aquisitivo e a renda da população deste município?

Há concentração de renda no município?

Se há concentração de renda, por gentileza, especifique.

Em razão de que essa concentração de renda ocorre no município? 
Há empresas agrícolas, ou seja, grandes propriedades que cultivam as frutas para atender a indústria de transformação das frutas produzidas nesse município?

Quantas e onde se concentram?

Pertencem a pessoas naturais desse lugar, ou de fora? De onde? 